\title{
"Our Own Flesh and Blood?": Delaware Indians and Moravians in the Eighteenth-Century Ohio Country.
}

Jennifer L. Miller

Follow this and additional works at: https://researchrepository.wvu.edu/etd

\section{Recommended Citation}

Miller, Jennifer L., "'Our Own Flesh and Blood?": Delaware Indians and Moravians in the EighteenthCentury Ohio Country." (2017). Graduate Theses, Dissertations, and Problem Reports. 8183.

https://researchrepository.wvu.edu/etd/8183

This Dissertation is protected by copyright and/or related rights. It has been brought to you by the The Research Repository @ WVU with permission from the rights-holder(s). You are free to use this Dissertation in any way that is permitted by the copyright and related rights legislation that applies to your use. For other uses you must obtain permission from the rights-holder(s) directly, unless additional rights are indicated by a Creative Commons license in the record and/ or on the work itself. This Dissertation has been accepted for inclusion in WVU Graduate Theses, Dissertations, and Problem Reports collection by an authorized administrator of The Research Repository @ WVU.

For more information, please contact researchrepository@mail.wvu.edu. 


\title{
"Our Own Flesh and Blood?": Delaware Indians and Moravians in the Eighteenth-Century Ohio Country
}

\author{
Jennifer L. Miller \\ Dissertation submitted to the \\ Eberly College of Arts and Sciences \\ At West Virginia University \\ in partial fulfillment of the requirements for the degree of
}
Doctor of Philosophy
in
History
Tyler Boulware, Ph.D., chair
Melissa Bingmann, Ph.D.
Joseph Hodge, Ph.D.
Brian Luskey, Ph.D.
Rachel Wheeler, Ph.D.
Department of History
Morgantown, West Virginia
2017

Keywords: Moravians, Delaware Indians, Ohio Country, Pennsylvania, Seven Years' War, American Revolution, Bethlehem, Gnadenhütten, Schoenbrunn

Copyright 2017 Jennifer L. Miller 


\section{ABSTRACT \\ “Our Own Flesh and Blood?": Delaware Indians and Moravians in the Eighteenth-Century Ohio Country}

\section{Jennifer L. Miller}

Between 1740 and 1790, Moravians and Delaware Indians fostered a spiritual and political alliance even as they endured a series of internal divisions and external threats. Although the relationship withstood the Seven Years' War, the American Revolution splintered both groups and estranged them from their neighbors. When the Revolution ushered in a radical new democracy that undermined the authority of eastern leaders, the Moravians proved powerless to control white settlers who enforced their own vision of justice against Native peoples. The Moravian-Delaware partnership unraveled as the dramatic upheaval of the American Revolution fundamentally reshaped the political landscape and rendered the alliance futile.

The Moravian-Delaware partnership is a striking example of intercultural cooperation during a period of intense conflict and change in the mid-Atlantic borderlands. Native peoples were drawn to the Moravians for a variety of reasons, including the role of women in the church, the Brethren's unique theology, and their overlapping spiritual practices, as scholars have noted. Equally significant, as my research suggests, was the alliance that the Moravians offered in an era plagued by political and cultural upheaval. Prior to the American Revolution, Pennsylvania's unique political dynamics allowed the Moravians to garner a degree of political influence that eluded them in other colonies and convinced Delaware leaders that the Brethren could be a valuable political ally in their quest to secure a homeland and protect their people. Despite the Moravians' marginal social position, they successfully developed connections within both Pennsylvania's Quaker and Proprietary factions. Moravian office-holders including William Edmonds, Timothy Horsfield, and William Henry cultivated associations with prominent leaders such as Governor Robert Morris and Benjamin Franklin and used their influence to address the concerns of those living in and around Moravian communities.

The Gnadenhütten Massacre of 1782 highlighted the racial violence that characterized much of the bloodshed in the west during the American Revolution as well as the breakdown of political authority in the outer edges of the state. I argue that it also offers a striking example of how Delaware men combined Native and Moravian understandings of manhood and demonstrates the extent to which some Indians adopted a distinctly Moravian model of masculinity. The massacre offered horrific proof that the Moravians could not protect the Delaware or their land from attack. But their failure was not a reflection of the Indians' misjudgment in cultivating an alliance with the Moravian church or the Brethren's unwillingness to use their political connections for the benefit of their Native friends. In spite of the Moravians' tenuous social position in eighteenth-century Pennsylvania, they proved to be savvy political actors and valuable allies to Native peoples until the American Revolution undermined their carefully established political connections and limited their ability to defend the mission communities. 
Dedication

To Weldon 


\section{Acknowledgements}

Composing these few short paragraphs is one of the more difficult tasks I've tackled in the course of writing this dissertation. My words cannot adequately convey my deep appreciation and gratitude to those who have offered their support and guidance as I struggled to transform a collection of thoughts and ideas into a coherent piece of scholarship.

I would like to thank the members of my dissertation committee, whose careful reading and probing questions forced me to think more deeply about the significance of my research and articulate my conclusions more clearly. My adviser, Dr. Tyler Boulware, reviewed several iterations of this work and never failed to offer insightful comments and suggestions; his perceptive critiques will undoubtedly shape the next stages of this project. Dr. Melissa Bingmann introduced me to the field of public history and her enthusiasm and encouragement inspired the epilogue to a study that would have otherwise ended in the early nineteenth century. Dr. Brian Luskey encouraged my ideas from the beginning and has provided advice on teaching, writing, and thinking like a historian. Dr. Joseph Hodge and Dr. Rachel Wheeler offered excellent recommendations for improving my dissertation's clarity and overarching argument. Although not a member of my dissertation committee, Dr. Kimberly Welch has served as an invaluable mentor. Her interest in my development as a scholar provided opportunities I had never considered and I cannot thank her enough.

I am grateful for the financial support that this project has received over the past six years. The Office of Graduate Education and Life at West Virginia University funded the earliest stages of my research through the Provost Graduate Fellowship. West Virginia University's Humanities Summer Fellowship allowed me to gain hands-on experience in the field of public history by supporting my work at the Senator John Heinz History Center in Pittsburgh. The William D. Barnes Award in West Virginia or Regional History, the Department of History Dissertation Research Fellowship, and an Eberly College of Arts and Sciences Graduate Travel Award funded my year at the Newberry Library in Chicago. The West Virginia University Foundation's Distinguished Doctoral Scholarship relieved me of teaching duties and provided financial resources for an additional semester of research. As the project neared completion, the National Society of the Colonial Dames of America Regional Scholarship Award provided for final research trips to the American Philosophical Society, Historical Society of Pennsylvania, and Moravian Archives; a Society of Mayflower Descendants in the State of Illinois Fellowship allowed me to spend an additional four weeks at the Newberry Library.

The Newberry Library welcomed me first as a graduate scholar-in-residence and later as a short-term fellow. There is no question that my time at the Newberry enriched my work and resulted in a much stronger dissertation. Although the collections at the Newberry played a significant role in this, it was the dynamic intellectual community that proved truly invaluable. This project benefited immensely from feedback I received when presenting portions of my work at the Newberry Library's D’Arcy McNickle American Indian Seminar Series and the Newberry Library's Colloquium, while the Newberry's Fellows Seminar Series provided an opportunity to engage with new research in fields beyond my own. My sincerest thanks to Linford Fisher, Rowena McClinton, and Daniel Usner, who took time from their busy research schedules to share advice over coffee. 
Writing can be a lonely endeavor, and I am thankful for the friends and colleagues who provided much-needed conversation and encouragement along the way. My fellow classmates Cassie Auble, Karina Garcia Esposito, Christine Grant, Megan McGee, and Lindsey McNellis supplied advice and laughter. Ben Scharff served as a debate partner for a variety of topics in eighteenth-century history and current politics during our weekly carpool from Pittsburgh to Morgantown. Although not historians, Susan Burnett Holtzman and Bianca Crowley offered valuable perspectives on school, career, and life when I needed them most.

This project would not have been possible without the support I received from my family. I entered WVU's doctoral program in the fall semester of 2011. Six years, five apartments, four cities, and two babies later, I am (finally) graduating. My deepest thanks to my mother, Phyllis Brown, and mother-in-law, Linda Miller, whose willingness to travel hundreds of miles to care for their granddaughter allowed me to spend hours buried in archives and hunched over a laptop. Thanks also to my father, Mark Brown, and brother, Douglas Brown, who have loaded and unloaded more packing boxes than it is reasonable to ask or expect. It is impossible for me to enumerate all of the ways that Weldon Miller has supported me and enriched my life during our years together. Our daughter, Alethia Rose, never fails to bring a smile to my face with her delightful antics and reminds me not to spend too much time focused on the past. The imminent arrival of her little sister promises that life will only grow richer (if perhaps more chaotic) in the coming years. 


\section{Table of Contents}

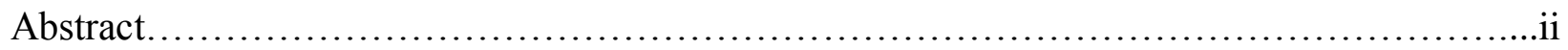

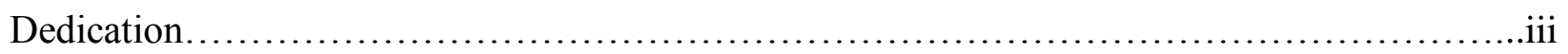

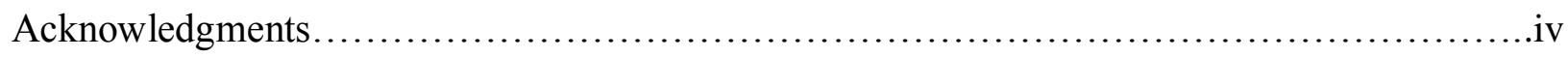

Introduction. ...................................................................

Chapter 1: Great Awakenings: The Emergence of the Delaware-Moravian Alliance............16

Chapter 2: "Like Sheep Among Wolves": The Moravians and the Delaware in the Seven Years' War.................................................................... 48

Chapter 3: A New Hope: The Ohio Country Missions.................................. 88

Chapter 4: "Our Own Flesh and Blood": Alliance and Kinship in the Ohio Country...........121

Chapter 5: "Years of Blood": The Collapse of the Delaware-Moravian Alliance...............158

Epilogue: Triumph in Death: The Ohio Missions in Public Memory.......................193

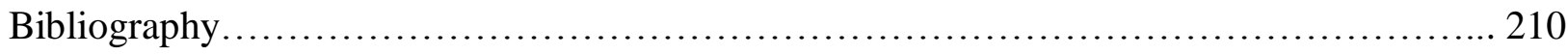




\section{Introduction}

On November 19, 1791, a troubled John Ettwein composed a letter to Secretary of State Thomas Jefferson. "I hope You will pardon the Liberty I take in troubling You with this Letter...Permit me, Sir, to relate to You the Situation of these Christian Indians." The Moravian Bishop explained that "terrifying Reports of the determined resistance of the white People on the Ohio" to prevent the Indians from returning to their homeland, combined with orders from the "Delaware Captain, the Wiondot and Tawa Chiefs" to "prepare for a Removal" had forced the Moravian converts to "petition the Brittish Government for Leave to come to the East Side of Lake Erie and lend them some land, where they could plant and live on until Peace should be restored." Ettwein concluded that "the Emigration of the said Indians was not by Choice but the most urgent Necessity" and urged Jefferson to protect the twelve thousand acres Congress had proposed to set aside for the Christian Indians in Ohio. ${ }^{1}$

Ettwein wrote from the town of Bethlehem, Pennsylvania, on behalf of David Zeisberger and his small congregation of Indian converts. The Moravian refugees had been seeking a safe haven since their forced removal from the Ohio Country a decade earlier. A series of abandoned settlements - in Sandusky and Detroit, on the Cuyahoga River and then the Pettquotting marked their flight as year after year the Moravians founded new mission towns in hopes of escaping the waves of violence that threatened their survival.

Between 1740 and 1790, Moravians and Delawares fostered a spiritual and political alliance even as they endured a series of internal divisions and external threats. Although the relationship withstood the Seven Years' War, the American Revolution splintered both groups and estranged them from their neighbors. When the Revolution ushered in a radical new

\footnotetext{
${ }^{1}$ John Ettwein to Thomas Jefferson, November 19, 1791. Founders Online, National Archives, https://founders.archives.gov/documents/Jefferson/01-22-02-0286.
} 
democracy that undermined the authority of eastern leaders, the Moravians proved powerless to control white settlers who enforced their own vision of justice against Native peoples. The Moravian-Delaware partnership unraveled as the dramatic upheaval of the American Revolution fundamentally reshaped the political landscape and rendered the alliance futile.

Nevertheless, the Moravian-Delaware partnership is a striking example of intercultural cooperation during a period of intense conflict and change in the mid-Atlantic borderlands. While earlier Native leaders forged relationships with Moravians and other Christian denominations in hopes of securing spiritual power, Delaware leaders in Pennsylvania and the Ohio Country looked to the Brethren to build a political alliance. This partnership extended beyond the boundaries of the mission towns and drew the Moravians into the Delaware's carefully constructed network of friends and kin. After the Seven Years' War disrupted Moravian outreach to Native peoples in Pennsylvania, Delaware leaders invited the Brethren to establish new missions in the Ohio Country. Some of the Indian leaders who proved instrumental in drawing missionaries westward held Nativist leanings and the decision to welcome the Moravians was far from uncontested. Prior to the Revolution, however, Pennsylvania's unique political dynamics allowed the Moravians to garner a degree of political influence that eluded them in other colonies and convinced Delaware leaders that the Brethren could be a valuable political ally in their quest to secure a homeland and protect their people.

When Ettwein penned his letter to Jefferson, fifty years had passed since a small group of German pietists founded Bethlehem along the banks of Monocacy Creek, a tributary of the Lehigh River, in eastern Pennsylvania. In its early years, Bethlehem expanded rapidly. The town served as the hub of Moravian evangelical efforts in North America, a local trading center, and a launching site for missions to Native peoples and European settlers. The Moravians, known 
formally as the Unitas Fratrum or Unity of the Brethren, arrived in the American colonies as the Great Awakening swept the countryside. During the 1720s, the Unity had reformed in Saxony under the leadership of Lutheran nobleman Count Nicolas Ludwig von Zinzendorf after long years in exile. Zinzendorf believed that true Christians were defined by their willingness to devote their hearts to the Lord rather than adherence to a specific doctrine, and he dismissed any deep study or understanding of the Scriptures as a necessary prerequisite to salvation. The Brethren practiced a highly emotional style of worship in keeping with the spirit of the Great Awakening and adopted an evangelic fervor that led them to establish mission posts throughout Europe, North America, Africa, and the Caribbean. ${ }^{2}$

The Moravians enjoyed a brief period of popularity upon their arrival to Pennsylvania. The celebrated evangelist George Whitefield invited them to stay on his estate, lending credibility to their missionary efforts. Zinzendorf, who hoped to unite the colony's many Protestant denominations in spiritual harmony, drew leaders from a number of churches to his "Ecumenical Synod" in Germantown. Before long, however, Whitefield had ordered the Brethren from his land over a seemingly minor theological dispute and a strong anti-Moravian movement coalesced among prominent Awakening theologians. Undaunted, the Moravians continued to minister to Pennsylvania's burgeoning German population until a series of protests

\footnotetext{
${ }^{2}$ By 1760, the Moravian Church had established mission towns in Lapland (Finland), Surinam, South Africa, the Gold Coast, Guyana, Jamaica, and Antigua in addition to their settlements in North America and Europe. The church continued to expand throughout the eighteenth and nineteenth centuries and became a global enterprise. For more information regarding the eighteenth-century Moravian Church, see Edmund De Schweinitz, The History of the Church Known as the Unitas Fratrum, or the Unity of the Brethren, Founded by the Followers of John Hus, the Bohemian Reformers and Martyr, $2^{\text {nd }}$ Edition (Bethlehem, PA: The Moravian Publication Concern, 1901); Craig D. Atwood, Community of the Cross: Moravian Piety in Colonial Bethlehem (University Park: The Pennsylvania State University Press, 2004); Mari Van Buijtenen, Cornelius Dekker, and Huib Leeuwenberg, ed., Unitas Fratrum (Utrecht: Rijksarchief, 1975); Michele Gillespie and Robert Beachy, ed., Pious Pursuits: German Moravians in the Atlantic World (New York: Berghahn Books, 2007).
} 
convinced them to refocus their efforts. ${ }^{3}$ Beginning in the late 1740 s, the Moravians expanded their missions to Native Americans, establishing a number of communities in the region. ${ }^{4}$

In recent years, scholars have delved into Moravian history focusing heavily on early Moravian missions to Native Americans, the evolution of Bethlehem, and missions to enslaved blacks in the Southern colonies and the West Indies. Much of the present research has highlighted how this radical religious minority complicates understandings of gender, race, and power in early America. My work draws on this rich body of Moravian scholarship and situates the Pennsylvania and Ohio mission towns in the broader context of the eighteenth century - a period characterized by imperial warfare, religious revival, and political upheaval.

When the Moravians arrived in North America, they joined a long line of Christians who sought to convert Native peoples. The Catholic church and a number of Protestant denominations had sent missionaries to minister to Indian communities, with varying degrees of success, from nearly the first point of contact. Some scholars have suggested that Native Americans turned to Christianity in desperation as their culture teetered on the edge of collapse after epidemics decimated their populations, colonists intruded on their lands, and rampant commercialism

\footnotetext{
${ }^{3}$ Aaron Fogleman's controversial Jesus is Female: Moravians and the Challenge of Radical Religion in Early America (Philadelphia: University of Pennsylvania Press, 2007) argues that the Moravians' willingness to grant women positions of power with the church outraged both theologians and the public who feared "female power run amok" (219) and reacted with violence. While Fogleman's thesis does suffer from a lack of substantial source material, historians generally agree that Moravian views and practices relating to gender were controversial and generated some degree of public titillation and outrage. This was particularly true during the "Sifting Time" of the 1740s. A number of intriguing works have explored various aspects of Moravian gender and sexual practices that emerged from their distinct "blood and wounds" theology. See Craig D. Atwood, Community of the Cross: Moravian Piety in Colonial Bethlehem (University Park: Penn State University Press, 2004), Paul Peucker, A Time of Sifting: Mystical Marriage and the Crisis of Moravian Piety in the Eighteenth-Century (University Park: Penn State University Press, 2015); also of note are Peucker's articles "Inspired by Flames of Love": Homosexuality, Mysticism, and Moravian Brothers around 1750," Journal of the History of Sexuality 15, no.1 (January 2006): 3064 and "Wives of the Lamb: Moravian Brothers and Gender around 1750" in Katherine Faull, ed. Masculinity, Senses, Spirit (Bucknell: Bucknell University Press, 2011). Katherine Faull's "Masculinity in the EighteenthCentury Moravian Mission Field: Contact and Negotiation," Journal of Moravian History 13, no. 1 (2013): 27-53 provides insight into how ideas of masculinity were negotiated in the mid-1740s-1750s.

${ }^{4}$ The Moravians had established missions to Native peoples prior to this point - Shekomeko (New York), Pachgatgoch (Connecticut), and Wechquadnach (Connecticut) were a few of the earliest, founded between 1740-42. See Aaron Spencer Fogleman Jesus is Female: Moravians and Radical Religion in Early America (Philadelphia: University of Pennsylvania Press, 2007) for information regarding protests.
} 
destroyed animal populations. ${ }^{5}$ However, a number of more recent historians have argued that Indians "had far more complex motives for adopting Christianity and Christianity had a variety of effects on their religious identity." ${ }^{\circ}$ As Linford Fisher points out, "Native religious engagement usually defied the more totalizing and complete notions that often frame the word 'conversion' which too often imposes Eurocentric ideas about religion on Native populations."7 Fisher suggests that rather than dwelling on the issue of "conversion" among Native populations, it is more accurate to reflect on how Native peoples engaged with and affiliated themselves with Christian missionaries in light of the "lived, on-the-ground realities of eighteenth-century Native lives."8 For Indian peoples along the eastern seaboard, perhaps the most concerning reality was their steady loss of land to Euro-American settlers. One line of argument that runs throughout this project is that Delaware leaders, betrayed by Iroquois allies who repeatedly sold Delaware land, cultivated relationships with the Brethren to secure land and ensure the survival of their people.

In the eighteenth century, Moravians proved particularly adept at drawing Native peoples to their mission towns. Although the Moravians ministered to Native peoples from a variety of tribes and nations, the early mission towns around Bethlehem were composed largely of Delaware (Lenape) Indians. By one estimate, the Brethren baptized ten to twenty percent of

\footnotetext{
${ }^{5}$ Calvin Martin, Keepers of the Game: Indian Animal Relationships and the Fur Trade (Berkeley: University of California Press, 1978); William Cronan, Changes in the Land: Indians, Colonists, and the Ecology of New England (New York: Hill and Wang, 1983).

${ }^{6}$ Jane T. Merritt, "Cultural Encounters Along a Gender Frontier: Mahican, Delaware, and German Women in Eighteenth-Century Pennsylvania," Pennsylvania History: A Journal of Mid-Atlantic Studies 67, no. 4 (Autumn 2000): 507; Kathleen DuVal, The Native Ground: Indians and Colonists in the Heart of the Continent (Philadelphia: University of Pennsylvania Press, 2006).

${ }^{7}$ Linford Fisher, The Indian Great Awakening: Religion and the Shaping of Native Cultures in Early America (Oxford University Press, 2012), 8.

${ }^{8}$ Ibid., 8.
} 
Delaware Indians living in Pennsylvania. ${ }^{9}$ Historians have offered a number of explanations for the Moravians' appeal, most of them grounded in the idea that the Brethren were uniquely situated to blend Christianity with Native cultural norms and social structures during this period. Unlike other Protestant denominations, the Moravians in Bethlehem organized their communities into "choir systems" that based living arrangements on age, gender, and marital status reminiscent of Indian longhouses rather than patriarchal households. ${ }^{10}$ Historians Jane Merritt and Aaron Fogleman argue that the Moravians offered an interpretation of Christianity that granted women more power and greater freedom within the church community - an appealing stance from the perspective of traditionally matrilineal peoples such as the Delaware. ${ }^{11}$ Similarly, Rachel Wheeler notes that although Mohican women approached the Moravian missions with caution, fearing that Christianity would threaten their religious power, these women "found new support for their authority within the community." ${ }^{12}$ Native women may have been motivated by more pragmatic concerns as well. Merritt suggests that Indian women viewed the settlements as havens where they could gain physical and spiritual protection from the devastating epidemics that periodically swept the region. These women sought to shield not only themselves, but perhaps more importantly, their children. As Amy Schutt illustrates, "Indians' desires for their children influenced their decision to join Moravian missions in sizable numbers." ${ }^{13}$ The mission

\footnotetext{
${ }^{9}$ Jane Merritt, "Dreaming in the Savior's Blood: Moravians and the Indian Great Awakening in Pennsylvania," The William and Mary Quarterly 54, No. 4 (October 1997), 737 n. 48.

${ }^{10}$ The Moravians at Bethlehem dismantled the choir system in 1762, before the Ohio missions were established.

${ }^{11}$ Merritt, At the Crossroads, and Fogleman, Jesus is Female.

${ }^{12}$ Rachel Wheeler, To Live Upon Hope: Mohicans and Missionaries in the Eighteenth-Century Northeast (Ithaca: Cornell University Press, 2008), 169. Wheeler notes that although Mohican women used Christianity to preserve familial and community bonds, the very "fact that they were searching for new sources of power is testimony of the disruptive force of colonialism." She also suggests that shifts in Moravian mission culture and policy during the mid-eighteenth century reflects emerging racial identities on the part of Moravian missionaries.

${ }^{13}$ Amy Schutt, “'What Will Become of Our Young People?': Goals for Indian Children in Moravian Missions," History of Education Quarterly 38, No. 3 (Autumn 1998): 271.
} 
towns not only held ample food stores but promised schools and stable kin-based communities as well. ${ }^{14}$

Native peoples were undoubtedly drawn to the Moravians for a variety of reasons, including the role of women in the church, the Brethren's unique theology, and their overlapping spiritual practices, as scholars have noted. Equally significant, as my research suggests, was the alliance that the Moravians offered in an era plagued by political and cultural upheaval. The Delaware were relative newcomers to the region, having been displaced by European settlers in the late seventeenth and early eighteenth centuries. This period saw rampant epidemics and widespread warfare, which decimated Native populations in the Delaware and Hudson river valleys. As a result, a number of Native groups who shared similar linguistic and cultural traits merged in order to survive. Europeans who encountered these peoples frequently referred to them as the "Delaware Nation," but this misnomer overstated the Indians' political and tribal cohesion. ${ }^{15}$ Over the course of the eighteenth century, the Delaware worked to establish political unity and define themselves as a people. Amy Schutt has examined the "profound significance" of peacemaking and alliance building in "the shaping of the Delaware as a people" and argues that the Delaware embraced these roles as they sought to solidify a cohesive identity in the eighteenth century. ${ }^{16}$ An alliance with the Moravians, known in both Native and colonial communities as a people with a peace-making mission, helped bolster this image.

\footnotetext{
${ }^{14}$ Some historians sharply disagree that Moravian towns offered Indian women any significant power, positing that the Delaware converted in an effort to secure their land, and that Native women maintained a role in spiritual affairs in spite of, rather than because of, Moravian beliefs. See Gunlog Maria Fur, A Nation of Women: Gender and Colonial Encounters Among the Delaware Indians (Philadelphia: University of Pennsylvania Press, 2009) and Amy Schutt, "Forging Identities: Native Americans and Moravian Missionaries in Pennsylvania and Ohio, 1765-1782," (Ph.D. Diss, Indiana University, 1995). Schutt portrays the Moravians as a strongly patriarchal sect, despite their openness to women's involvement in the church.

${ }^{15}$ Ibid., 3.

${ }^{16}$ Amy Schutt, Peoples of the River Valleys: The Odyssey of the Delaware Indians (Philadelphia: University of Pennsylvania Press, 2013), 4-5.
} 
The Delaware were never monolithic in their strategies for securing their land and future, however. While some Delaware actively joined Moravian mission towns, others demurred but nurtured a relationship with the Brethren that did not include shared spiritual pursuits. A significant number of Delaware rejected any form of partnership with Christian missionaries; by the 1740s, several bands of Delaware had moved to the Ohio country, where they formed multicultural villages and alliances with militant Seneca, Mingo, and Shawnee peoples. ${ }^{17}$ While those who remained in the east continued to seek allies in their quest to protect their land from the tide of Europeans immigrating to the region, western Delaware embraced the nascent revitalization movements that urged Native peoples to adopt a pan-Indian identity. In his extensive studies on Indians' "religiously charged struggle for unity," Gregory Dowd argues that debates over Indian identity "affected Indian actions in every conflict between the Seven Years' War and War of 1812." ${ }^{18}$ But even as pan-Indian movements drew together peoples from a number of nations, tribes, and clans, they simultaneously divided Native communities against one another. ${ }^{19}$ Amy Schutt and Hermann Wellenreuther have explored how the Delaware attempted to navigate this tension; my work seeks to expand this discussion by considering how Delaware leaders envisioned a relationship with the Moravians reuniting the eastern and western branches of their people and why their strategy failed.

When the Seven Years' War (1754-1763) unleashed waves of violence in Pennsylvania's borderlands, the Moravians and their Native converts found themselves threatened by western

\footnotetext{
${ }^{17}$ Although the Seneca were members of the Iroquois Confederacy, the western bands who lived in the Ohio Country were largely independent and were less inclined to negotiate land deals with colonists.

${ }^{18}$ Gregory Evans Dowd, A Spirited Resistance: The North American Indian Struggle for Unity, 1745-1815 (Baltimore: The Johns Hopkins University Press, 1992), xiii. Dowd's War Under Heaven also explores themes of identity and sovereignty during the mid-eighteenth century. See Gregory Evans Dowd, War Under Heaven: Pontiac, The Indian Nations, and The British Empire (Baltimore: The Johns Hopkins University Press, 2002).

${ }^{19}$ Amy Schutt explores how the Delaware in particular navigated this tension, see Schutt, Peoples of the River Valleys; Hermann Wellenreuther discusses how the three clans of the Delaware took different approaches to relations with missionaries in his helpful article "White Eyes and the Delaware's Vision of an Indian State," Pennsylvania History: A Journal of Mid-Atlantic Studies 68, no. 2 (Spring 2001): 139-61.
} 
Indians, who wished to reclaim their homelands and drive settlers back to the eastern seaboard, and by their white neighbors, who eyed all Native peoples with suspicion. The outbreak of war raised serious questions about the core belief systems of the church and its missions to Native peoples. The Moravian pacifists abandoned their stance on absolute non-violence and fortified Bethlehem against attack - a move that may have protected the residents and refugees that overwhelmed the town, but also compromised their standing in the wider community. Neighbors who witnessed the Moravians' stockpiling ammunition even as they denounced violence began to question where their loyalties lay and rumors that the Moravians were secretly supplying hostile Indians swirled. At the same time, settlers viewed the carnage wrought by western bands of Ohio Indians and bitterly denounced Quaker politicians who advocated for peaceful means of reconciliation rather than committing to open warfare. As the violence escalated, attacks on the Quaker political class and their Moravian allies increased. By the end of the war, much of the population had turned against the Quaker political class and embraced a new racial ideology that cast all Native peoples as dangerous "others." 20

At first glance, the Delaware's attempt to garner political influence through their relationship with Moravian missionaries appears misguided. Since the early 1740s, the Moravians had been assailed by religious authorities because their unorthodox beliefs about the Christian trinity, marriage and sexual practices, and willingness to grant women leadership positions in the church challenged the prevailing gender hierarchy. ${ }^{21}$ But during the Seven Years' War, anti-Moravian fervor became widespread throughout Pennsylvania. Settlers in the borderlands may have harbored fears that the Moravians constituted a threat to gender norms during a time when male patriarchy was being undermined as a result of the rampant violence in

\footnotetext{
${ }^{20}$ Peter Silver, Our Savage Neighbors: How Indian War Transformed Early America (New York: W.W. Norton and Company, 2008).

${ }^{21}$ See Fogelman, Jesus is Female, and Peucker, A Time of Sifting.
} 
the borderlands, but their primary concern was that the Brethren served as a dangerous ally to potentially hostile Native Americans. ${ }^{22}$ As Peter Silver and others have shown, the bloody warfare that swept through Pennsylvania during the Seven' Years' War was a catalyst for transforming the polyglot inhabitants of the borderlands into "white Folks" who united to fight against Indians - regardless of the Natives' tribal or religious affiliation. Pacifist groups such as the Moravians, Quakers, and other German peace churches in Pennsylvania were excluded from this new "white" identity not only because they refused to participate in armed attacks against Native people, but because they rejected the idea that all Indians were "enemies." ${ }^{23}$ What these studies fail to emphasize, however, is the degree of political influence that the Brethren maintained during and after the Seven Years' War. Despite the Moravians' marginal social position, they successfully developed connections within both Pennsylvania's Quaker and Proprietary factions. Moravian office-holders including William Edmonds, Timothy Horsfield, and William Henry cultivated associations with prominent leaders such as Governor Robert Morris and Benjamin Franklin and used their influence to address the concerns of those living in and around Moravian communities.

\footnotetext{
${ }^{22}$ Krista Camenzind has suggested that the violence that swept the Pennsylvania frontier during the Seven Years' War destabilized the patriarchy of the backcountry because it "interrupted men's abilities to farm, to control their land and the labor of their dependents, and to protect their dependents from an outside threat." See Krista Camenzind, "From the Holy Experiment to the Paxton Boys: Violence, Manhood and Race in Pennsylvania During the Seven Years' War" (Ph.D. Diss., University of California, San Diego, 2002), 251.

${ }^{23}$ Patrick Griffin's work has also pinpointed the emergence of racial identity and racial hatred to the latter half of the eighteenth century. Nonetheless, Moravian and Native understandings of race appear more nuanced. Both Zeisberger and Heckewelder routinely apply the label "white" to non-Moravian Euro-Americans, regardless of their ethnicity or circumstances, while often (albeit not always) exempting themselves from this group. Even acculturated captives, who were as or more familiar with Native life than the Moravians, were "white." This suggests that while the Germans did not necessarily consider themselves white, they did see race as a permanent trait that remained even if captives adopted the language, customs, and beliefs of their Native captors. For their part, Indians who were familiar with or sympathetic to the Moravians often differentiated between the pacifist Moravians and "whites," while Natives who were hostile to missionary efforts in the Ohio region appear less willing to make this distinction. See Peter Silver, Our Savage Neighbors, and Patrick Griffin, American Leviathan: Empire, Nation, and Revolutionary Frontier (New York: Hill and Wang, 2007).
} 
When Delaware leaders invited the Moravians to the Ohio Country in 1772, they did so with an eye toward developing an alliance that would garner influence with Pennsylvania officials and unite Christian Delaware living in the eastern Moravian missions with their western kin. ${ }^{24}$ But neither the Indians nor the Moravians could have foreseen the new war on the horizon. As the American Revolution unfolded, Delaware leaders found themselves torn between conflicting allies and powerless to keep the war from their land or hold together their tenuous unity. The Delaware may have nurtured an identity as peacemakers, but they did not hesitate to engage in warfare when it was determined necessary to protect their community or interests. Factions of the Delaware joined Shawnee and Wyandot warriors in sweeping raids against settlers in western Pennsylvania, even as the Head Council struggled to maintain Delaware neutrality. In an effort to convince both the British and the Americans of their neutrality and pacifism, the Moravians provided provisions and shelter to all who passed through their towns. Rather than averting hostilities, this tactic led both sides to accuse the Moravians of aiding the enemy - an accurate charge that the Brethren struggled to deny.

Bethlehem grappled with the same issues confronting the Brethren in the Ohio Country. Moravian leaders urged their members to refrain from engaging in the revolutionary movement and adhere to the church's formal policy of neutrality. But just as the Delaware splintered between those who advocated for peace and those who believed the time for war had come, the Moravians were plagued by internal dissent. Some congregants supported independence from the start; others joined American forces after Pennsylvania’s Test Act and Militia Law targeted the Brethren and other peace churches in the state. Where the Ohio missions were forced to contend

\footnotetext{
${ }^{24}$ Herman Wellenreuther and Carola Wessel, ed., The Moravian Mission Diaries of David Zeisberger, 1772-1781 (University Park, PA: The Pennsylvania University Press, 2005), 51.
} 
with Native peoples who urged them to declare sides, those in eastern Pennsylvania faced backlash from their Euro-American neighbors.

During the Revolutionary War years, opposition to the Moravians was multifaceted. Their resistance to Pennsylvania's Test Act and Militia Law made them easy targets for charges of loyalism in the east, while their continued relationships with Native peoples infuriated settlers in the west. In both Bethlehem and the Ohio Country, the greatest threat to Moravian settlements and their Native converts came from their neighbors. In earlier eras, charges against the Moravian church stemmed from prominent religious and political leaders, but during the Revolution the Moravians' carefully cultivated political allies intervened on their behalf. Unfortunately, new political dynamics at play in the state limited authorities' ability to reign in the "rank-and-file patriots." ${ }^{25}$ As the war progressed, rural settlers and their elected leaders seized on revolutionary rhetoric and increasingly rejected eastern leadership in favor of charting their own course of action - often to the detriment of the Moravians and their Native affiliates.

The infamous Gnadenhütten Massacre, which left ninety-six Moravian Indians dead, highlighted the racial violence that characterized much of the bloodshed in the west during the American Revolution as well as the breakdown of political authority in the outer edges of the state. I argue that it also offers a striking example of how Delaware men combined Native and Moravian understandings of manhood and demonstrates the extent to which some Indians adopted a distinctly Moravian model of masculinity. As Ann Little has convincingly shown, Native and Euro-American societies had much in common in terms of gender expectations and ideals - particularly in the realms of political diplomacy and military service, almost exclusively male domains. Men were judged by their military prowess and masculinity was understood in

\footnotetext{
${ }^{25}$ Scott Paul Gordon, "Patriots and Neighbors: Pennsylvania Moravians in the American Revolution" Journal of Moravian History, 12 no. 2 (2012): 122. Gordon's article examines Moravian communities in eastern Pennsylvania. Many of his conclusions can be applied to western Pennsylvania and the Ohio Country, however.
} 
opposition to femininity. When Native and colonial men hurled insults at one another deriding their opponents' manhood, such remarks hit their target because both cultures accepted a comparable set of gender hierarchies. ${ }^{26}$

Delaware leaders may have pursued an identity as peacemakers between peoples, but they were also steeped in a cultural tradition that valued bravery and participation in warfare. Their understanding of peacemaking did not preclude violence if circumstances were deemed to warrant it. Indian men confronted a different kind of masculinity in Moravian men who embraced pacifist teachings and refused to take up arms. Nonetheless, a number of prominent Delaware leaders and respected warriors joined the Ohio missions and rejected the use of violence even as their own communities were threatened by Native warriors and white militia men. While many of the Gnadenhütten massacre victims were women and children, experienced Delaware warriors such as Israel Welapachtschiechen and Isaac Glikhicken were among the dead. Both men were experienced leaders who had garnered respect for their bravery in battle prior to converting to Christianity. Nonetheless, they joined their peers in singing hymns and offered no resistance as they knelt before their executioners. Both Native and Euro-American cultures expected men to strenuously defend their freedom and honor, which often entailed engaging in violence. The Christ figure stood as the ideal of masculinity for eighteenth-century Moravians, however, and thus men who willingly suffered and sacrificed their bodies for their beliefs proved their manhood. Men who allowed themselves to be intimidated and coerced into

\footnotetext{
${ }^{26}$ Ann M. Little Abraham in Arms: War and Gender in Colonial New England (Philadelphia: University of Pennsylvania Press, 2007). For further discussion on masculinity and ideas of manhood in early America, see R. Todd Romero Making War and Minting Christians: Masculinity, Religion, and Colonialism in Early New England (Amherst: University of Massachusetts Press, 2011) and Michelle LeMaster Brothers Born of One Mother: BritishNative American Relations in the Colonial Southeast (Charlottesville: University of Virginia Press, 2012).
} 
turning their back on their moral principles - such as the Brethren who capitulated in the face of Pennsylvania's Test and Militia Law - were "unmanned."27

For Native peoples, the Gnadenhütten Massacre offered horrific proof that the Moravians could not protect the Delaware or their land from attack. But their failure was not a reflection of the Indians' misjudgment in cultivating an alliance with the Moravian church or the Brethren's unwillingness to use their political connections for the benefit of their Native friends. As they had during the Seven Years' War, the Brethren used every avenue at their disposal to protect the Moravian Indians during the Revolutionary War. Their diligence in seeking to protect their Native converts is often overlooked but vital for understanding why Native peoples - whether Christian or not - sought to maintain ties with the Moravian Church. In spite of the Moravians' tenuous social position in eighteenth-century Pennsylvania, they proved to be savvy political actors and valuable allies to Native peoples until the American Revolution undermined their carefully established political connections and rendered the Moravian-Delaware alliance futile.

John Ettwein's letter to Thomas Jefferson was only one of many that he dispatched to political leaders at the state and national level in his tireless campaign to secure a homeland for the Moravians' Indian converts. On June 1, 1796, his efforts were finally rewarded when the United States Congress approved an act granting the Society of United Brethren for Propagating the Gospel Among the Heathen twelve thousand acres of land in Ohio. The tracts encompassed the abandoned villages of Schoenbrunn, Gnadenhütten, and Lichtenau.

The Seven Years' War was a turning point for the Moravian missions in Pennsylvania and the Ohio Country, but the Revolutionary War proved to be the undoing of the Moravian-

\footnotetext{
${ }^{27}$ During the Revolutionary War, Moravian Bishop John Ettwein argued that men should be willing to suffer "for the sake of their principles" and those who were "frightened and unmanned" by threats against them were condemned to a "shameful existence." See John Ettwein to Mattheus Hehl, June 1, 1777[?] in Kenneth Hamilton, John Ettwein and the Moravian Church During the Revolutionary Period (Bethlehem, PA: Times Publishing, 1940), 243.
} 
Delaware alliance. Despite Ettwein's successful efforts to secure lands formally recognized by the United States government - and thus reasonably safe from white settlers - the Moravians were never able to reestablish a thriving mission community in the Ohio region. The Ohio missions withered as the result of racialized violence against Native Americans and the Moravians' own estrangement from the white community during the American Revolution. During the Seven Years' War and in the early years of the Revolution, Moravian leaders were able to rely on their political connections to shield their towns and congregants from persecution. But the Revolution ushered in a new era of radical democracy that undermined the authority of eastern leaders and curtailed the Moravians' ability to function as valuable political allies. 


\section{Chapter 1 \\ Great Awakenings: The Emergence of the Delaware-Moravian Alliance}

"My Lord," the Reverend George Whitefield wrote furiously, “...for these many years last past I have been silent, and, I trust I can say, an impartial observer of the progress and effects of Moravianism both in England, and America; but such shocking things have been lately brought to our ears, and offenses swell'd to such an enormous bulk, that a real regard for my King, my country, and...the ever blessed Jesus...will not suffer me to be silent any longer.”28 Turning to the most frequent criticisms leveled against the Moravians, Whitefield demanded to know where "we hear any thing in scripture of eldresses or deaconesses" and accused Count Nicholas Zinzendorf and some of his "leading brethren" of "misguiding many real, simple, honest-hearted Christians; of distressing, if not totally ruining numerous families, and introducing a whole farrago of superstitions." ${ }^{29}$ Published in 1753, Whitefield's An Expostulatory Letter Addressed to Nicolas Lewis, Count Zinzendorf, and Lord Advocate of the Unitas Fratrum, represented a dramatic about-face for the celebrated evangelist. Whitefield had invited the Moravians to settle on his estate in Pennsylvania a decade earlier, after the German Pietists ran afoul of authorities in Georgia for their refusal to bear arms during the War of Jenkins' Ear. But Whitefield was only one of many religious elites who turned to the press to denounce the Moravians and their religious teachings as the fervor of the Great Awakening wound to a close. For the next thirty years, Moravians in America struggled against accusations that stemmed from their unorthodox religious practices, their close relations with Native peoples, and their attempts to steer a neutral course during times of war.

\footnotetext{
${ }^{28}$ George Whitefield, An Expostulatory Letter Addressed to Nicholas Lewis, Count Zinzendorf, and Lord Advocate of the Unitas Fratrum, $2^{\text {nd }}$ Edition (London: Printed for G. Keith, 1753), 4.

${ }^{29}$ Ibid., 5.
} 
The decades surrounding the Seven Years' War were a time of turmoil for both colonists and Native Americans. Prior to the outbreak of violence in 1754, Pennsylvania witnessed a marked increase in the number of non-English and non-Quaker immigrants settling in the colony, drawn by the prospects of abundant farmland and religious tolerance. Many of these newcomers journeyed to Indian country to establish family farms. The colonial government proved itself unable to control the squatters who edged across the western boundaries of the colony, provoking many Native Americans who resided on the land. Even as tensions between the colonial government and Indians rose, divisions among Pennsylvania's Native inhabitants intensified. The long-standing alliance between the Delaware and Iroquois splintered as the Iroquois negotiated land deals with the Pennsylvania government that resulted in huge swaths of Delaware land being sold out from under the tribe.

While land and property rights were a source of conflict in the mid-eighteenth century, other areas of contention were less tangible. Pennsylvania prided itself on religious tolerance, a stance that fostered a diverse array of spiritual beliefs and believers. Religious beliefs did not merely influence ideas of salvation and afterlife, but had profound implications for gender roles, family life, and power structures within societies. In the midst of the Great Awakening, both colonists and Native Americans experienced religious movements that emphasized new paths to salvation. Rather than engendering an atmosphere of brotherly love, however, the end result of such diversity was often conflict and at times violence between and within Native and EuroAmerican communities. It was in this period of uncertainty that Moravians and Delaware Indians, both relative newcomers to the region, came together as each struggled to secure a place in the Pennsylvania borderlands. Their intercultural alliance began as a spiritual encounter at a 
time when both communities were in the midst of religious revivals, but evolved into a political and diplomatic alliance that extended beyond the borders of the mission towns.

The Moravians ventured to the outskirts of colonial settlement in 1740, planting a small community of believers along the Lehigh River in eastern Pennsylvania. The members of this pietist sect had a long history of persecution and displacement in Europe. Colloquially known as the Moravians, the Unitas Fratrum or Unity of the Brethren traced their roots to the early Czech reformer Jan Hus. The Unity expanded rapidly in the fifteenth century but was largely broken in the face of violence and persecution during Europe's Thirty Years War (1618-1648). ${ }^{30}$ In the early eighteenth century, however, the descendants of the exiled Moravians began to make their way to the estate of the Lutheran nobleman Count Nicolas Ludwig von Zinzendorf in Saxony. ${ }^{31}$ The reemergence of the Moravian church coincided with the spread of Pietism, an international religious movement, and the Great Awakening, which swept Protestant Europe and British North America into throes of religious revival.

Zinzendorf would prove himself the spiritual leader of the eighteenth-century Moravian church. Under his leadership, the Moravian Church expanded rapidly and adopted a missionary

\footnotetext{
${ }^{30}$ The Thirty Years' War (1618-1648) proved catastrophic to the young Unity. After the Protestant Bohemian army fell to Catholic forces at the Battle of White Mountain (1620), many Protestants converted to Catholicism. Others continued to worship clandestinely or fled the region in search of more hospitable lands. In 1627, all Protestants living in Bohemia and Moravia were given the choice to either convert to Catholicism or go into exile. Although the Unity was largely broken in the face of violence and persecution, a few small communities of displaced Moravians migrated to Poland, where they struggled to rebuild the church. Count Lesczynski of Poland proved amenable, and the city of Leszno became an important center for the Unity until 1656, when it was destroyed in a war between Poland and Sweden. In 1648, when the Peace of Westphalia ended the Thirty Years' War, the Unity was denied legal status in the Holy Roman Empire. The remnants of the Unitas Fratrum abandoned hope of returning to Moravia or Bohemia and struggled to survive in exile in Poland and Prussia. Many struggling congregations were slowly absorbed into other churches. See Craig D. Atwood, Community of the Cross: Moravian Piety in Colonial Bethlehem (University Park: The Pennsylvania State University Press, 2004); Harry E. Stocker, Moravian Customs and Other Matters of Interest (Bethlehem, PA: Times Publishing Co., 1918); Edmund De Schweinitz, The History of the Church Known as the Unitas Fratrum, or the Unity of the Brethren, Founded by the Followers of John Hus, the Bohemian Reformers and Martyr, $2^{\text {nd }}$ Edition (Bethlehem, PA: The Moravian Publication Concern, 1901).

${ }^{31}$ As Atwood notes in Community of the Cross, there is some debate whether those who migrated to Zinzendorf's estate had preserved the beliefs and practices of the original Unitas Fratrum. The Moravian Church (and their historians) maintain that a "Hidden Seed" of devout Moravians continued kept the church alive between 1627, when members of the Unity were forced into exile, and 1722, when they began arriving on Zinzendorf's estate. See Atwood, Community of the Cross, 21-24.
} 
zeal that led them to establish outposts around the globe. ${ }^{32}$ Born in 1700 , the son of Saxon nobility, Zinzendorf was raised on the estate of his grandmother, Baroness Henrietta Catherine von Gersdorf. The Baroness was a highly educated and deeply pious woman. She read the Bible in its original languages and regularly corresponded with well-respected theologians and philosophers. Zinzendorf adopted his grandmother's deep religious zeal and as a young man embraced the teachings of the Halle Pietists - so much so that his family began to grow concerned. Although Zinzendorf's family had no qualms with Pietist theology, they expected the young count to eventually assume his position in society. When Zinzendorf informed his family that he wished to devote his life to the ministry, they removed him from Halle and transferred his studies to the University of Wittenberg, the center of Lutheran orthodoxy. At Wittenberg, he studied law and at the age of twenty-one adhered to his families' expectations and became a judicial counselor in Dresden. Zinzendorf shortly thereafter married Erdmuth Dorthea von Reuss and purchased his grandmother's estate of Berthelsdorf. Zinzendorf's bride was herself devoted to pietism and the couple shared the conviction that their marriage was a Streiter Ehe - a “militant marriage" dedicated to Christian service. ${ }^{33}$

Berthelsdorf soon became a gathering place for religious refugees. In 1722, a small group of Protestants arrived from Moravia, only weeks after the count purchased the land. The Moravians christened their small community Herrnhut; over the next few years the town slowly increased in size. Although the Moravians at Herrnhut traced their community back to the Unity of the Brethren, the renewed church was fundamentally shaped by Zinzendorf. The count moved

\footnotetext{
32 In Community of the Cross, Atwood notes that there is "little concrete evidence for the continued existence of the Unity in Bohemia or Moravia" between the destruction of the church during the Thirty Years War and the eighteenth century, although there is evidence that the Protestants more broadly continued to worship in secret during and after the war. Atwood, Community of the Cross, 21-4.

${ }^{33}$ Atwood, Community of the Cross, 46-49; Elizabeth Zorb, "Reflections on Moravian Pietism," Pennsylvania History: A Journal of Mid-Atlantic Studies, Vol. 25, No. 2 (April, 1958): 115-21; Enoch Pond, Memoir of Count Zinzendorf: Comprising a Succinct History of the Church of the United Brethren from Its Renewal at Herrnhut to the Death of Its Illustrious Patron (Boston: Massachusetts Sabbath School Society, 1839), 2-45.
} 
to Herrnhut in 1727 , formally established the community within the Lutheran parish, and convinced those living in the community to sign a "Brotherly Agreement" outlining the spiritual life of the town. In the covenant, the Brethren "individually engaged to belong entirely to the Savior" and confessed that they "were ashamed of their religious quarrels" and "sincerely renounced self-love, self-will, disobedience and free thinking." 34 The Brethren, in turn, elected Zinzendorf to the office of superintendent, where he was charged with overseeing "all of the concerns of the church." ${ }^{35}$ During this period, the Herrnhutters reorganized their community into a communal system, establishing "choirs" that organized living arrangements based on age, sex, and marital status. The church regulated economic activities within Herrnhut; all property was owned collectively. ${ }^{36}$

As a wealthy nobleman, Zinzendorf was able to protect Herrnhut from the Lutheran Saxon authorities who tolerated but distrusted the Moravians in their midst - for a time. But his actions roused many in the Saxon aristocracy. In 1736, accusations that the count was “encouraging religious separatism" resulted in Zinzendorf being thrown into exile, although Saxon officials allowed the Herrnhutters to remain. ${ }^{37}$ The following year, Zinzendorf was consecrated as a Moravian bishop, although he retained his position as an ordained Lutheran minister as well.

Since his time at the University of Wittenberg, Zinzendorf's theology had been moving away from Halle orthodoxy. He rejected Halle's understanding of the conversion experience as a time of intense struggle, instead choosing to believe that each individual came to Christ in their

\footnotetext{
${ }^{34}$ August Gottlieb Spangenberg, The Life of Nicholas Lewis Count Zinzendorf, Bishop and Ordinary of the Church of the United (or Moravian) Brethren, trans. Samuel Jackson, (London: Samuel Holdsworth, 1838), 83.

${ }^{35}$ Spangenberg, The Life of Zinzendorf, 84.

${ }^{36}$ Michele Gillespie and Robert Beachy, eds., Pious Pursuits: German Moravians in the Atlantic World (New York: Berghahn Books, 2007), 5.

${ }^{37}$ Atwood, Community of the Cross, 60.
} 
own unique way, which might or might not involve a period of painful questioning. Craig Atwood suggests that Zinzendorf and the Herrnhutters were heavily influenced by Jan Amos Comenius, whose vision for social reform was based on "simplicity, spontaneity, and unity." 38 Indeed, communities like Herrnhut were "laboratories in which Comenius's millennial dream was partially recognized." ${ }^{39}$ Unlike many Pietist sects, which sought to shield their members from worldly temptations by retreating to insular agricultural communities, under Zinzendorf the Moravians "managed to look simultaneously inward and outward."40 While the communal Herrnhut sheltered its members and removed them from the concerns of the larger world, it also launched a program of vigorous evangelical work that scattered Moravian missionaries throughout the world.

The Moravians began their international work as the "First Great Awakening" swept the Atlantic World. During the 1730s and 1740s, thousands of men, women, and children flocked to Christian revivals throughout Great Britain, British North America, and the Caribbean. In colonial America, revivalism and religious ardor varied by region and were driven by different forces. New England saw perhaps the most widespread and intense fervor; Pennsylvania and the other mid-Atlantic colonies witnessed significant revivalism as well. Celebrity preachers embraced a new, captivating style of preaching that emphasized individuals' personal conversion experience and offered religious and spiritual authority to anyone who experienced a "new birth" in Christ. During this relatively brief period, when formal education was no longer a prerequisite to spiritual authority, formerly disenfranchised groups including women, Indians, and blacks,

\footnotetext{
38 Atwood, The Theology of the Czech Brethren from Hus to Comenius (University Park: The Pennsylvania State University Press, 2009), 370.

${ }^{39}$ Ibid., 402.

${ }^{40}$ Gillespie and Beachy, Pious Pursuits, 5.
} 
shouldered their way into this seemingly more egalitarian public religious sphere. ${ }^{41}$ The evangelical fervor that the Great Awakening sparked tended to "take ethnic and racial boundaries lightly," although most of the prominent figures of the time failed to denounce the legal or social subjugation of black Americans or Indians even as they preached spiritual equality. ${ }^{42}$ The Great Awakening fostered a religious climate that proved beneficial to the Moravians, who held that true believers were defined only by their willingness to give their hearts to Christ. Deep study or understanding of the Scriptures was not a prerequisite for salvation. As the Moravians' spiritual leader, Zinzendorf emphasized that the Brethren "learn nothing of their conduct out of Books," but rather found themselves when the "Holy Spirit seizes the Heart."43

In 1732 - only five years after the Brethren signed their "Brotherly Agreement" at Herrnhut - the first Moravian missionaries arrived in St. Thomas in the West Indies. The following year, they established a mission in Greenland. By 1760, the Moravians had expanded their evangelical outposts to include North America, Lapland (Finland), Surinam, South Africa, West Africa's Gold Coast, Guyana, Jamaica, and Antigua. ${ }^{44}$ The first Moravian evangelical efforts in America took place in Georgia. The young colony was eager for settlers and open to religious minorities; other religious refugees, including the German speaking Salzburgers, also set their sights on the southern British colony. In 1735, a mere three years after the colony was

\footnotetext{
${ }^{41}$ There is some debate among historians regarding the nature of the First Great Awakening. Indeed, some question whether such an event occurred at all or if the Great Awakening is merely - in Jon Butler's words - an "interpretive fiction" invented by modern historians. For more on this debate, see Jon Butler, "Enthusiasm Described and Decried: The Great Awakening as Interpretive Fiction," Journal of American History 69, no. 2 (September 1982): 305-25; Thomas Kidd, The Great Awakening: Roots of Evangelical Christianity in Colonial America (New Haven: Yale University Press, 2007); Frank Lambert, Inventing the 'Great Awakening' (Princeton: Princeton University Press, 2001).

${ }^{42}$ Kidd, Great Awakening, 30.

${ }^{43}$ Henry Rimius, A Candid Narrative of the Rise and Progress of the Herrnhutters, Commonly Call'd Moravians or Unitas Fratrum, with a Short Account of their Doctrines Drawn from Their Own Writings (London: A. Linde, 1753), 49.

${ }^{44}$ Robert L. Gallagher, "Zinzendorf and the Early Moravian Mission Movement” (paper presentation, Wheaton College, September 21, 2005), accessed at https://www.scribd.com/document/212680155/Zinzendorf-and-the-EarlyMoravian-Mission-Movement, 1.
} 
established, August Gottlieb Spangenberg disembarked with a small group of Moravian men and settled in Savannah. The following year, twenty-five more missionaries arrived under the leadership of Bishop David Nitschmann. The Moravians quickly set about ministering to the local inhabitants, establishing a school for Creek Indians in nearby Irene and a mission for slaves in Purrysburg, South Carolina. Despite their initial success, the Moravian missions quickly faltered. As tensions between England and Spain escalated in the War of Jenkin's Ear, the Moravians came under increasing pressure to bear arms in defense of the colony. Although the missionaries had the assurances of colonial officials that they would not be forced into combat against their will, the Moravians decided to start fresh in Pennsylvania, where pacifism was not only tolerated but embraced by many. ${ }^{45}$

In 1740, the celebrated evangelist George Whitefield offered the Moravians passage to Pennsylvania and a home on his landholdings there. Whitefield's willingness to help speaks to the Moravian's favorable position in America's evangelical community at this time - a position that would soon change. Bishop Nitschmann and the Moravians who traveled to Georgia in 1736 had sailed with John Wesley, the Anglican minister and theologian who would later found the evangelical Methodist church. Although these close ties with prominent church leaders soon frayed, the Moravians arrived in Pennsylvania positioned to continue their missionary efforts to both local German settlers and Native peoples. In May 1740, the Moravians settled on Whitefield's estate, Nazareth, in the lush Lehigh Valley and set about working as carpenters, helping Whitefield construct a school for free black children. ${ }^{46}$ What initially appeared to be a minor theological dispute between Whitefield and Moravian leader Peter Bohler over the nature

\footnotetext{
45 Vernon Nelson, “The Moravian Church in America," in Unitas Fratrum, ed. Mari Van Buijtenen, Cornelius Dekker, Huib Leeuwenberg, (Utrecht: Rijksarchief, 1975), 145-9.

${ }^{46}$ Nelson, "The Moravian Church in America," 146-47.
} 
of universal redemption, however, soon left the Moravians homeless. ${ }^{47}$ Six months after their arrival, Whitefield demanded that the Moravians vacate his property. Despite this inauspicious beginning, the Moravians quickly secured a plot of five hundred acres a few miles from Nazareth and laid the cornerstone of the Bethlehem mission town in 1741. Bethlehem was to be the heart of Moravian evangelization efforts in North America. The town functioned as a trading center and a launching site for missions to Native American and Euro-American settlements, while the surrounding fields ensured a steady food supply and allowed the mission to remain largely selfsufficient. ${ }^{48}$ Months after establishing Bethlehem, the Moravians convinced Whitefield to sell them his five thousand acre Nazareth estate.

Pennsylvania's Moravian mission system expanded rapidly throughout the 1740 s. The Bethlehem complex included not only a trade and manufacturing center, dormitories, and a schoolhouse in Bethlehem proper but also the farming communities of Nazareth, Christianbrunn, Gnadenthal, and Friedensthal. The imposing structures that comprised the settlement included some of the largest buildings in the colony. ${ }^{49}$ In 1746 , Gnadenhütten was established roughly forty miles northwest of Bethlehem, sprawling from under two hundred acres to encompass 1,382 acres in less than a decade. ${ }^{50}$ The extensive attention that Bethlehem has received from historians tends to obscure the fact that not all Moravians in America resided in settlement towns. Bethlehem was the only community of its kind in Pennsylvania, establishing a residential

\footnotetext{
${ }^{47}$ Atwood, Community of the Cross, 116. The Moravian later purchased Nazareth from Whitefield and it became the primary farming community for the Bethlehem complex.

${ }^{48}$ Ibid., 116-7. Unlike other religious groups migrating to Pennsylvania in the eighteenth century, the Moravians tended to relocate in carefully organized communities. Most had received training that prepared them for missionary work and travelled to North America specifically for that purpose.

${ }^{49}$ Ibid., Community of the Cross, 120.

${ }^{50}$ Jane Merritt, At the Crossroads: Indians and Empires on a Mid-Atlantic Frontier, 1700-1763. (Chapel Hill: University of North Carolina Press, 2003), 132. This was the first mission town named Gnadenhütten, which collapsed in 1755 after an attack by French-allied Indians. Another mission town by the same name was established in 1772 in the Ohio Valley. This second settlement is where the more widely known Gnadenhütten Massacre occurred.
} 
choir system and serving as a testing ground for the "General Economy." The General Economy structured the town as a commune in hopes of avoiding dependency on outside merchants and limiting worldly influences. The church owned all property, and residents worked together to grow crops, manufacture goods, prepare meals, and raise their children. ${ }^{51}$ Residents were not paid for their labor, but received housing, food, clothing, and medical care in exchange for their time and efforts. Bethlehem's communal economy emerged directly from the town's commitment to mission work and thus "the Moravians' religious lives and their economic lives merged into one." ${ }^{52}$ The year that Bethlehem was founded, the town boasted 131 residents; by 1751, it had grown to 744. In 1753, as the region poised on the brink of war, Bethlehem and its sister settlements - Nazareth, Gnadenhütten, Gnadenthal, Friedensthal, and Christiansbrunn boasted a combined population of over $1,200 . .^{53}$

In June 1742, Zinzendorf divided Bethlehem's residents into two distinct groups. The pilgrim congregation was responsible for mission work throughout the region, while the house congregation, composed of those who would remain in Bethlehem, worked to support missionaries in the field. Zinzendorf emphasized that these two groups were equal and both contributed to the same ultimate goal - spreading the word of God to unbelievers. Without the house congregation, the work of the pilgrim congregation would not be possible. In Zinzendorf's eyes, providing financial and material support for those in the field was essential for the success of the mission; he warned the missionaries that "you could make yourselves spiritual servants and slaves, as soon as you let yourselves take money. ${ }^{" 54}$ Furthermore, these groups were not

\footnotetext{
${ }^{51}$ Atwood, Community of the Cross, 118-9; Aaron Spencer Fogleman, Jesus is Female: Moravians and the Challenge of Radical Religion in Early America (Philadelphia: University of Pennsylvania Press, 2007), 86-7. 
static. Members of the pilgrim congregation would periodically return to Bethlehem and work alongside those in the house congregation.

From the beginning, Bethlehem perched between two worlds. In one, all economic decisions and residents' daily lives revolved around the church and its missionary efforts. At the same time, the economic success required to maintain those efforts depended on close interaction with the surrounding settlements. Unlike many other religious communities in Pennsylvania during this period, the Moravians focused on developing an artisanal economy rather than an agricultural one. Bethlehem drew people throughout the region who came to take advantage of its black smithy, tannery, saddlery, gristmill, sawmill, oil mill, and pottery shop. ${ }^{55}$ This choice was a result of the towns' own needs and its residents' skills. Erecting a village in the borderlands required a steady stream of goods and building materials. Financially, it made sense to establish the means of production rather than continually rely on goods imported from eastern cities. Furthermore, many of the Moravians arriving from Europe were skilled artisans. As Spangenberg noted in 1751, the Moravians worked to "cultivate all crafts, particularly those that are indispensable to us, and useful to others, e.g., the tannery, wagonry, potters, etc., so that we will not only avoid paying money that we would otherwise have to, but also something will come into the coffers, and we will incur all the fewer debts." 56 There was an additional benefit to this system. Aside from the fact that the success of agricultural communities was dependent on circumstances beyond their control - months of labor (and livelihoods) could be laid to waste by a late frost, freak hailstorm, or relentless drought - agricultural communities, by their nature, also tended to limit interactions with outside peoples. By establishing an artisanal economy, the Moravians created a reason for potential converts to come to them and knit themselves into the

\footnotetext{
${ }^{55}$ Engel, 39.

56 “Spangenberg's Gedanken,” Spangenberg Papers, Moravian Archives Bethlehem, PA, in Engel, 53.
} 
fabric of the borderlands. This strategy was successful. When the Brethren opened the Crown Inn to accommodate travelers in 1745 , it hosted some two hundred visitors in the first eight months. ${ }^{57}$ Agriculture was nevertheless important to the Moravian complex, even if it was not the primary focus. While Bethlehem was the artisanal center, Nazareth was the agricultural center. The Brethren produced most of the crops they needed to support their community but also purchased additional supplies when necessary.

As Katherine Carté Engel notes, the success of the General Economy can be attributed to its pragmatism. The Moravians at Bethlehem "were more interested in supporting missionary work than they were in challenging the nature of the early modern economy," and as a result, "their communalism was never economically absolute." 58 This perhaps explains why the system worked so well for as long as it did. Residents of Moravian Bethlehem contributed to the combined labor system and received food, shelter, clothing, and childcare in lieu of wages. They did not, however, hand over private property that they possessed prior to joining the settlement community. Individuals maintained their personal wealth, real estate, and all other worldly possessions. Much like the decision to create an artisanal economy, this decision had a number of direct and indirect consequences. Allowing residents to maintain their own financial resources while serving within the General Economy enabled those who may have grown disenchanted with the Moravians to leave easily, thus maintaining a harmonious communalism among those who remained firmly committed to missionary work. At the same time, this system supported the social hierarchies that characterized the outside world. While these hierarchies were muted by

\footnotetext{
${ }^{57}$ Engel, 38-41. For information on the Crown Inn, see S.M. Parkhill, “Crown Inn Housed Bethlehem's Early Visitors,” The Morning Call, June 16, 1998 http://articles.mcall.com/1998-06-16/news/3194833_1_sun-innmoravians-farms.

58 Ibid., 39.
} 
the fact that the community resided in choir houses, dressed plainly, and deferred to decisions made by the Elder's Council and the Lot, they existed nonetheless. ${ }^{59}$

Rather than residing in traditional familial households, the Moravians in Bethlehem pioneered a "choir system" like that in Herrnhut, which established households based on age, gender, and marital status and dictated where a member of the congregation lived, worked, and worshiped. The choir, instead of the biological family, became the most influential social unit to which an individual belonged. ${ }^{60}$ Married couples lived separately, meeting occasionally in "special sleeping quarters," and sent their children to reside in the Children's Choir as soon as the infants were weaned. ${ }^{61}$ The Moravians firmly believed that relationships between people similar in age, sex, and marital status best fostered spiritual growth and knowledge. The choir system recognized the different needs of various groups within the community and sought to address the spiritual needs of each individual. ${ }^{62}$ The religious instruction of children was deemed particularly important, and the Children's Choir guided its members in developing a "personal experience of Christ," as they were taught the values of communal living and the more practical details of a gender-appropriate trade. ${ }^{63}$ Every choir had its own liturgy, hymn book, and held separate choir services in addition to the congregational worship services.

\footnotetext{
${ }^{59}$ Ibid., 56-8.

${ }^{60}$ Gunlog Maria Fur, A Nation of Women: Gender and Colonial Encounters Among the Delaware Indians. (Philadelphia: University of Pennsylvania Press, 2009), 57.

${ }^{61}$ Fogleman, Jesus is Female, 94-6. In Bethlehem, the choir system divided married couples into separate choirs. This was not a universal practice, however. As Atwood maintains in Community of the Cross, the Bethlehem mission town adopted a more extreme choir system than many other Moravian communities in America or Europe. In other communities, only children who had entered puberty and unmarried or widowed adults lived with their choir.

62 Amy Schutt, "Female Relationships and Intercultural Bonds in Moravian Indian Missions," in Friends and Enemies in Penn's Woods: Indians, Colonists, and the Racial Construction of Pennsylvania, ed. William A. Pencak and Daniel Richter (University Park: The Pennsylvania State University Press, 2004), 90.

${ }^{63}$ For a detailed explanation of the Moravian choir system, see Atwood, Community of the Cross, 173-99; Fogleman, Jesus is Female, 86-104; Beverly Smaby, "Female Piety Among Eighteenth Century Moravians," Pennsylvania History 64 (Summer 1997): 151-67; Lillian Gollin, "Family Surrogates in Colonial America: The Moravian Experiment," Journal of Marriage and Family 31 (November 1969): 650-8.
} 
Both the General Economy and the choir system developed as a means to meet the practical day to day requirements of the town while allowing men and women the flexibility necessary to engage in missionary work. The choir system profoundly changed life for women in Bethlehem, breaking the monotonous toil of housework and child rearing that characterized many colonial women's lives and providing them leadership roles within the church. Women were routinely appointed to church governing boards and ordained as Acolytes, Eldresses, Deaconesses, and Pristerinnen (female ministers), positions that allowed them to minister to the community and lead absolution and footwashing ceremonies. ${ }^{64}$ Although women were not permitted to deliver sermons in services that included men, they could preach to members of their own choir, administer (though not consecrate) the Communion, and ordain other women. ${ }^{65}$ While many of the Christian denominations that flourished during the Great Awakening relied on single, male missionaries to spread their religious doctrine, Moravians strongly preferred to send married couples. Given the strict division of the sexes that Moravians maintained, having women missionaries available to shoulder the responsibility of ministering to and educating the female members in the mission field was a high priority. ${ }^{66}$ Because the education and welfare of children was recognized as a community responsibility, married couples could leave their children in the care of the town while they left for extended mission trips, traveling from Bethlehem to regions as far north as the Hudson Valley in New York and south to the Shenandoah Valley in Virginia. ${ }^{67}$ Although female missionaries were typically married women engaged in mission work alongside their husbands, there were a handful of

\footnotetext{
${ }^{64}$ Smaby, "Female Piety," 151-157.

${ }^{65}$ Ibid. In Jesus is Female, Fogleman disagrees with Smaby and suggests that Moravian women did preach to mixed groups of men and women throughout America and Europe. Count Zinzendorf, head of the Moravian church until his death in 1760, edged around the issue of women preaching by declaring that although the Bible specifically forbade wives to speak in church (as it was disrespectful to their husbands), this restriction did not necessarily apply to single and widowed women. For further discussion, see Jesus is Female, 96-7.

${ }^{66}$ Fur, 57.

${ }^{67}$ Fogleman, Jesus is Female, 100.
} 
single, young women who traveled throughout the region organizing love feasts and revivals for non-Moravian women. ${ }^{68}$

Despite the extensive attention that Bethlehem and its choir system have received from historians, not all Moravians lived in this type of community. Eastern Pennsylvania, New York, and North Carolina were all home to a number of "town and country congregations" where members lived in conventional households and - outwardly at least - differed little from their non-Moravian neighbors. Those Moravians who chose not to live in a settlement community often faced scrutiny from settlement Moravians and church leaders alike. Zinzendorf himself questioned whether it was wise to have members of the Brethren living in mixed communities. Living "in the world" both limited opportunities to devote one's life to missionary service and offered numerous temptations that might cause one to lose focus on spiritual matters. Nonetheless, as Scott Paul Gordon has argued, the Moravians benefitted from members who chose to "involve themselves in the corrupting and noisy world," as the Seven Years War and American Revolution would later demonstrate. ${ }^{69}$

As 1741 wound to a close, Zinzendorf arrived in the American colonies. After landing in New York, he traveled to Bethlehem. Fittingly, he formally christened the settlement Bethlehem on Christmas Eve. Zinzendorf harbored an ecumenical vision of Christian unity in the face of increasingly splintered Protestant denominations and wasted little time pursuing this vision. The seemingly chaotic state of religion in Pennsylvania - particularly among German immigrants made it ripe for revival. Zinzendorf's dream of drawing churches together in interdenominational harmony met with some success in 1742 when he managed to gather leaders from the Lutheran, German Reformed, Presbyterian, Anglican, Quaker, Mennonite, Dunker,

\footnotetext{
${ }^{68}$ Ibid., 98.

${ }^{69}$ Scott Paul Gordon, "Entangled by the World: William Henry of Lancaster and "Mixed" Living in Moravian Towns and Country Congregations," Journal of Moravian History 8 (2010), 7-52.
} 
Sabbatarian, Inspired, and Separatist churches for an "Ecumenical Synod" in Germantown. ${ }^{70} \mathrm{His}$ victory was fleeting, however, and the promise of ecumenical unity died amidst interdenominational squabbling. Undaunted, Zinzendorf and his followers focused instead on ministering to the burgeoning German population in the colonies. ${ }^{71}$

The vast majority of German-speaking immigrants belonged to either the Lutheran or German Reformed communities and were pulled to America by the prospect of economic opportunity rather than pushed by religious persecution. Nonetheless, many of them were quite religious and troubled by the lack of ordained pastors and established churches in the Pennsylvania countryside. German church leaders, either unaware of or unconcerned by their shepherdless flocks in North America, failed to recruit ordained pastors to migrate to the colonies. ${ }^{72}$ The Moravians filled this void, traveling throughout Pennsylvania and into neighboring colonies where they hosted revivals and hymn sings, offered their doctoring skills, and helped communities erect church buildings and schools. ${ }^{73}$ In the spirit of the Great Awakening, Moravian ministers embraced an emotional style of preaching and focused their sermons on the bloodshed and suffering of Christ. Unlike oppositional church leaders, most German settlers were unconcerned with dogmatic purity and flocked to hear the Moravian speakers. ${ }^{74}$

As the Moravians gained influence and attracted followers during the 1740s, Pennsylvania's Lutheran pietists spearheaded an opposition movement to combat what they considered the Moravians' radical ideology. Leaders of the German Reformed and Lutheran

\footnotetext{
${ }^{70}$ Fogleman, Jesus is Female, 108-10.

71 Ibid., 111-2.

72 Aaron Fogleman, "Jesus is Female: the Moravian Challenge in the German Communities of British North America," The William and Mary Quarterly 60 (April 2003), 298-302.

${ }^{73}$ Fogleman, Jesus is Female, 126.

${ }^{74}$ Fogleman, Jesus is Female, 118-25.
} 
churches flooded the countryside with pamphlets and books that detailed the dangerous beliefs of the Moravians and urged residents to drive Moravians from their areas. ${ }^{75}$ These polemics, issued from church leaders in Europe and printed in New York and Philadelphia, attacked the Moravians for very real violations of religious and social norms as well as highly exaggerated (and at times fantastical) transgressions. Authors warned that the Moravians' radical depiction of the feminine Trinity and the role women played in church leadership distorted and defied Biblical teachings. The Moravians' odd ideas of marriage and sex turned their commune into a "whoredom" where wives dominated their husbands. As one author warned, "a Husband is also properly no more than a Chamberlain of his Wife; his Office is but for a Time and ad interim."76 To the Moravians' enemies, the choir system represented not only a dangerous trend of women's empowerment, but undermined the hierarchical power system upon which society rested.

Anti-Moravian theologians also decried what they considered to be the Moravians' blind following of Count Zinzendorf's deranged and perverse theological dictates, claiming that "Zinzendorf exercised more than a Papal power over his society and that a Blind Obedience was paid him in whatever he directed." ${ }^{\text {"77 }}$ Moreover, they warned, Zinzendorf's feigned interest in ecumenical co-operation concealed a malevolent plot to infiltrate other denominations. Indeed, Lutheran theologian Siegmund Baumgarten claimed that the Moravians were attempting to destroy the Lutheran church outright. Some questioned whether the Moravians would stop even after destroying other denominations. "May not the Safety of the Government depend on their good Will?," one concerned author queried. ${ }^{78}$

\footnotetext{
${ }^{75}$ Fogleman, "Moravian Challenge in German Communities," 331.

${ }^{76}$ Henry Rimius, A Candid Narrative, 50.

${ }^{77}$ Ibid., 62.

78 Ibid.
} 
Although the anti-Moravian fervor originated with German religious leaders, other prominent evangelists began to distance themselves from the Moravians as well. As early as 1742, George Whitefield clarified his prior association with the Moravians, writing "some there are suspicious that I am joined with the Moravian Brethren, but indeed I am not. . Some of my principles differ from theirs and are as far different as the East is from the West." ${ }^{79}$ By 1753 , Whitefield had joined in the attacks against the Moravians, accusing them of destroying Christian families and leading believers astray. Presbyterian minister Gilbert Tennent and Methodist John Wesley also denounced the Moravians, with Tennent describing their "most dangerous doctrines" and alarming ability to "delude the weak, tho honest minds into Measures which might have a tendency to the subversion of the Gospel of Christ." 80

With the weight of prominent Awakening leaders behind the anti-Moravian accusations, colonists began to eye the Moravians suspiciously. Scattered protests, at times leading to physical altercations, occurred periodically throughout the 1740s. Aaron Fogleman has suggested that the level of violence against Moravians throughout the Middle Colonies during this decade was significantly higher than most historians have recognized and led the Moravians to avoid holding revivals aimed at Euro-American colonists in favor of expanding Indian missions in the early $1750 s^{81}$

\footnotetext{
${ }^{79}$ George Whitefield, The Works of the Reverend George Whitefield, M.A. Late of Pembroke-College, Oxford, and Chaplain to the Rt. Hon. the Countess of Huntingdon (London: Printed for Edward and Charles Dilly, 1771), 441. ${ }^{80}$ Gilbert Tennent, Some Account of the Principles of the Moravians: Chiefly Collected from Several Conversations with Count Zinzendorf; and from some sermons (London: Printed for S. Mason, 1743), iii.

${ }^{81}$ Fogleman, Jesus is Female, 212. Fogleman's claim has generated some criticism from other historians. In his review of Fogleman's work, Craig Atwood argues that "church divisions, legal actions, and personal attacks were not uncommon during the 1740s or other periods of religious fervor" and suggests that the opposition to the Moravian church was not as "unusual or particularly violent" as Fogleman maintains. See Craig Atwood, review of Jesus is Female: Moravians and the Challenge of Radical Religion in Early America, by Aaron Spencer Fogleman in The American Historical Review 113 no. 1 (2008): 167-8. Other historians have documented that Moravian beliefs and practices around gender did result in cultural conflict, however. In particular, see Paul Peucker's articles "Inspired by Flames of Love": Homosexuality, Mysticism, and Moravian Brothers around 1750," Journal of the History of Sexuality 15, no.1 (January 2006): 30-64 and "Wives of the Lamb: Moravian Brothers and Gender around 1750" in Katherine Faull, ed. Masculinity, Senses, Spirit (Bucknell: Bucknell University Press, 2011).
} 
The Moravians appealed to German settlers by combining a recognizable liturgy with emotionally charged presentations, but they were also uniquely prepared to minister to the region's Native Americans. Unlike many other denominations, the Moravians offered Native Americans an interpretation of Christianity that granted women more power and greater freedom within the church community, focused on personal experience and feeling, and represented less of a break with Native religious traditions than other strains of Christianity. Throughout the 1740s and well into the Seven Years' War, Moravian missions to Indians in Pennsylvania flourished. Given the location of the Moravian settlement in the Lehigh Valley, there were a number of Delaware Indian towns in close proximity. Like the Moravians, the Delaware were recent arrivals to the region. As Moravian religious refugees made their way to Zinzendorf's estate in the early part of the eighteenth century, a continent away the Delaware were being displaced by Europeans fleeing religious persecution. Delaware Indians who left their homeland in the Delaware Valley established new communities along the Susquehanna and Lehigh Rivers. Some of the towns, most notably Wechquetank and Meniolagomekah, became strongholds of Moravian teachings but maintained populations of Christian and non-Christian Indians living alongside one another. Other towns rejected overtures from the Moravians to send missionaries but established trading connections. The borders between Moravian and Delaware towns were fluid, and baptized Delaware remained connected to non-Christian Indians through expansive kin networks. ${ }^{82}$

The Moravians began their intensive missionary efforts to the Delaware at a time when the Delaware were struggling to solidify their identity as a group and define themselves as a people. Throughout the seventeenth century, Europeans encountering Algonquian peoples in the Hudson and Delaware Valleys routinely used the term "Delaware" to describe members of what

\footnotetext{
${ }^{82}$ Fogleman, Jesus is Female, 133-4.
} 
they perceived as a "nation" or "tribe." Although these Indians shared linguistic and cultural patterns, their similarities did not represent political or tribal unity. ${ }^{83}$ To label them a "nation" or "tribe" was almost certainly inaccurate; furthermore, it is unclear precisely which groups of people seventeenth-century Europeans included in their references to the "Delaware Nation." In the midst of rampant epidemics that wiped out huge swaths of the Native population in the wake of contact with Europeans - not to mention the warfare that often resulted from the ensuing power vacuums - the Algonquians who called this region home adapted by merging with other Native groups. ${ }^{84}$ Survival in the face of disease and war required the peoples of the Delaware and Hudson Valleys to maintain a "flexible approach to social organization" that "promoted intergroup cooperation and a layering of multiple associations." 85

Historian Amy Schutt suggests that it was not until the mid-eighteenth century that the Delaware developed a cohesive identity even as they "remained a group with permeable boundaries and even though they were not monolithic in viewpoint and organization." 86 During this period, the Delaware worked to define themselves as "alliance builders" and "peacemakers" who carefully nurtured connections with Native peoples and, at times, with Euro-Americans. These bonds linked them not only to other groups of people - hopefully powerful ones - but also to sources of spiritual power in the natural world. The Delaware enjoyed a close relationship with Pennsylvania's founder William Penn and negotiated a series of land deals with the Quaker as he established his "peaceful kingdom" in the New World. Like many Indian peoples, the

\footnotetext{
${ }^{83}$ The Delaware River was named after Sir Thomas West - Lord de la Warr - the governor of Virginia. The terms "Lenape" and Delaware" refer to the same group of Native peoples and are often used interchangeably; Lenape is a Native term, meaning "original person" or "real person." Europeans were the first to routinely refer to these peoples as "Delaware." The term "Delaware," according to Amy Schutt, "gained importance as an ethnic/political designation in the course of the eighteenth century." See Amy C. Schutt, Peoples of the River Valleys: The Odyssey of the Delaware Indians (Philadelphia: University of Pennsylvania Press, 2007), 3.

${ }^{84}$ Ibid., 3, 34.

${ }^{85}$ Ibid., 31.

${ }^{86}$ Ibid., 5.
} 
Delaware understood land "ownership" in terms of land usage rather than exclusive rights to a given property. There is some evidence that the Delaware approached Penn with a mind to secure an alliance and develop a long-term partnership. The Delaware leader Sassoonan recalled that "When Wm. Penn first came in he called the Indian leaders together" and asked to "purchase their Lands but they Said they would give it to him." ${ }^{87}$ Penn noted that the Indians "presented me with several parcels of Land" in addition to those that he bought, but he likely failed to grasp that such gift giving carried with it future obligations and was only the first offering in a cycle of reciprocal giving.

This initial misunderstanding was complicated by Penn's financial situation. By the late 1680s, the proprietor was burdened with significant debt, which led him to disperse his land payments over time as he acquired the necessary funds. A situation born out of financial necessity inadvertently played into Delaware expectations of land transactions as ongoing relationships. Disgruntled colonists complained that "As we bought our Land in England to be free from Indian Title \& Incumbrances... We cannot but be concerned that of [such] title the Land be clear'd by plain \& Regular purchases," and expressed their concern that Penn was "engaged in 'Reciprocall kindenesse... in his daily gifts \& presents to the Indians." 88

When Penn died in 1718, the Delaware found themselves facing a new political reality. John and Thomas Penn had no regard for the carefully developed relationship between their father and the Delaware. Their concern was ridding themselves of debt, and to do so they needed land. The Penn brothers turned to the Iroquois and over the next several years formed an alliance with the Six Nations that rewarded both sides at the expense of Pennsylvania's other Native

\footnotetext{
${ }^{87}$ James Logan to Sassoonan, August 13, 1731, Penn Manuscripts, Indian Affairs I, Penn Family Papers, Historical Society of Pennsylvania, in Schutt, Peoples of the River Valleys, 35.

${ }^{88}$ Richard S. Dunn et al., eds., The Papers of William Penn, Vol. 2 (Philadelphia: University of Pennsylvania Press, 1982), 573.
} 
peoples. By the 1740s, Pennsylvania had acquired massive sections of Delaware territory through questionable means. The Delaware attempted to resist the steady march of settlers onto their lands by appealing to their Indian allies, particularly the Iroquois. They were stunned when the Iroquois responded by siding with the Pennsylvanians and denying that the Delaware had any claim to their land, declaring "We conquered you; we made Women of you; you know you are Women, and can no more sell land than women." ${ }^{\prime 89}$

Scholars have debated at length what exactly this statement reveals about relations between the Delaware and Iroquois. Certainly Euro-American observers understood it to mean that the Delaware were subordinate to the Iroquois. Native peoples likely had a much more nuanced understanding. According to David Zeisberger, the Iroquois and Delaware had entered into an alliance in which "one nation should be the woman" who was placed under the protection of "the other nations, who make war." This "woman" would not engage in warfare, but would "endeavor to keep the peace with all." ${ }^{90}$ Because of this agreement, the "Delaware nation is thus looked to for the preservation of peace." ${ }^{.1}$ In this telling, the Iroquois had no ground to claim that they "conquered" the Delaware. Indeed, Zeisberger notes that the alliance emerged because "with the Delaware the Six Nations carried on long wars...but the former were always too powerful for the Six Nations" and the Iroquois "were convinced that if they continued the wars, their total extirpation would be inevitable." 92 Whatever the nature of the Iroquois-Delaware relationship, it is unquestionable that the Iroquois repeatedly sold land claimed by the Delaware, Shawnee, and Susquehanna Indians residing in Pennsylvania.

\footnotetext{
${ }^{89}$ Alden T. Vaughan, ed., Early American Indian Documents: Treaties and Laws, 1607-1789, Vol. 2 (Frederick, MD.: University Publications of America, 1984), 42, in Schutt, Peoples of the River Valleys, 90.

${ }^{90}$ Archer Butler Hulbert and William Nathaniel Schwarze, eds., David Zeisberger's History of the Northern American Indians (Columbus: Press of F.J. Heer, 1910), 34.

${ }^{91}$ Ibid., 35.

92 Ibid., 34.
} 
The Delaware had long embraced a practice of shared land use that allowed territory sharing with allies. After Penn's death and the proprietors' turn to the Iroquois, their attempt to continue this system with Euro-Americans failed. The Delaware's struggle to renegotiate their position with Pennsylvania's colonial leaders and reassert their power in relation to the Iroquois ultimately led them to split internally. In the 1740s, several bands of Delaware abandoned efforts to negotiate with British colonists and relocated to the Ohio Country, where they formed multicultural villages and alliances with militant Seneca, Mingo, and Shawnee peoples. ${ }^{93}$ Those who remained in the east continued to seek allies in their quest to protect their land from the tide of Europeans immigrating to the region.

The Moravians settled along the Lehigh River as competition for land between the Delaware and Lehigh rivers - the "forks of the Delaware" - intensified. The German Brethren were unwitting beneficiaries of the infamous 1737 "Walking Purchase" that had swindled thousands of acres from the Delaware people. Nonetheless, significant numbers of Delaware eventually joined the missions. The Indians' willingness to pursue a relationship with the Moravians and draw the missionaries into their network of allies was in keeping with their larger goals of securing power, solidifying their identity, and seeking spiritual and political benefit through mediation and alliance building. Furthermore, the Moravians' unconventional interpretation of Christianity and accompanying practices made them particularly appealing allies.

The Moravian success in Indian mission towns can in part be attributed to the role of women in the church. Rather than stripping Indian women of their traditional spiritual authority as most other Protestant denominations did, Moravians offered them the chance to enhance their

\footnotetext{
${ }^{93}$ Although the Seneca were members of the Iroquois Confederacy, the western bands who lived in the Ohio Country were largely independent and were less inclined to negotiate land deals with colonists.
} 
standing in the community. Because the choir system divided worshipers by gender and age, Moravian women held separate services for Indian women, met with individuals and in small groups to discuss spiritual matters, and administered communion. The gathering of women to contemplate spirituality and engage in formalized ritual was somewhat familiar to Delaware women, who were accustomed to ceremonial celebrations surrounding first menstruation and marriage that "highlighted the separateness of female experience." ${ }^{94}$ Perhaps most significantly, Moravian women selected and trained Delaware women to become eldresses, a role that allowed them to act as lay ministers. Native eldresses "proselytized to unconverted neighbors, blessed newly baptized children, and listened to and translated other Native women's professions of faith." ${ }^{95}$ This approach was particularly successful, and was likely the reason that the Moravians baptized more Indian women than any other Protestant missionary effort. ${ }^{96}$

Despite the comparatively egalitarian nature of Delaware society, men and women largely operated in separate spheres. Men were more likely to pursue activities outside of the village and were frequently absent for extended periods on hunting or military expeditions. Women farmed, gathered wild fruits and berries, prepared animal skins for trade or clothing, and cared for their villages' children. ${ }^{97}$ Because clan affiliation was passed from mother to child, the relationship between siblings was elevated over that of husband and wife and marriage was a fluid institution. Households were organized around maternal kinship networks, in which women owned their houses and material goods. In the Delaware societal structure, women held authority over decisions within the household and the clan while men wielded power when dealing with

\footnotetext{
${ }^{94}$ Schutt, "Female Relationships," 90.

${ }^{95}$ Merritt, At the Crossroads, 104.

${ }^{96}$ Ibid., 102.

${ }^{97}$ Schutt, "Female Relationships," 92-3.
} 
broader village, district, or tribal matters. ${ }^{98}$ Although decisions regarding warfare and diplomacy ultimately fell to men, women retained some political power by naming the chief leader of their village. They also held the power to initiate raids to secure captives if a member of their clan was killed in warfare and determined whether the subsequent captives would be adopted or ritually tortured and killed. ${ }^{99}$ The distinct divisions between men and women in Delaware society rested on a delicate balance of power that found its counterpart in the gender-defined roles of the Moravian missionaries.

Beyond the visible role that women played in the day-to-day activities of the Moravian church, Moravian theology relied heavily on female imagery and reconceptualized the traditional view of the Holy Trinity to emphasize what they considered its maternal nature. The Holy Trinity, comprised of the God the Father, Jesus the Son, and the somewhat ambiguous Holy Spirit, was broadly understood in the Protestant world as a masculine triumvirate of spiritual power. In the early 1740s, the Moravians' leader Count Zinzendorf gave a series of sermons espousing the view of the Holy Spirit as the "mother" of Jesus Christ and, by extension, all of humanity. The fact that Indian (and other "pagan") societies often recognized goddesses or mother figures in their creation myths was evidence, he claimed, that the Holy Spirit was the mother of all. ${ }^{100}$ In addition to claiming a maternal identity for the Holy Spirit, Zinzendorf maintained (somewhat confusingly) that Jesus Christ was the omnipotent creator of the universe, thereby stripping "God the Father" of his previously accepted role. The Moravians also embraced a metaphorical depiction of Jesus as a mother, emphasizing both the nurturing nature of the Christian Savior and the understanding that believers were re-born through Christ.

\footnotetext{
${ }^{98}$ Merritt, At the Crossroads, 54.

${ }^{99}$ Anthony Wallace, The Death and Rebirth of the Seneca (New York: Alfred A. Knopf, 1969), 28-9. Although Wallace discusses the Seneca, Delaware society shared these practices.

${ }^{100}$ Fogleman, Jesus is Female, 75.
} 
Although historians disagree just how far the Moravians carried the metaphor of Jesus as female, they concur that the Moravians challenged traditional understandings of the Holy Trinity as a symbol of and justification for patriarchal power. ${ }^{101}$ Zinzendorf developed the theological basis for the feminized Trinity, but it was common men and women who shared this belief with the Indians and settlers they encountered.

The theological underpinnings of the Moravian church likely influenced Native American converts less than other overlapping spiritual practices. Both Euro-American Christians and Indians pondered the meaning of dreams and visions, and recognized dreams as glimpses into the supernatural world. At times, their dreams bore an uncanny resemblance to one another, reflecting the influence of Christian teachings on Native beliefs. Trader James Kenny wrote in his journal of a dream in which there appeared "a Glorious Person Possited over me like toward the firmament the attire of his head looked bright a shining Star on his forehead," while Native Keposch told a Moravian missionary of his vision where he encountered "a man in a bright white robe floating in the air." 102 Indians understood that dreams held specific instructions for the dreamer, and actively sought to fulfill their visions while Euro-Americans were more apt to view dreams as metaphors or veiled messages. Jane Merritt has suggested that in Moravian

\footnotetext{
${ }^{101}$ Fogleman, Jesus is Female; Smaby, "Female Piety"; Merritt, "Cultural Encounters"; Merritt, At the Crossroads; Merritt, "Dreaming in the Savior's Blood"; Fur, Nation of Women; Schutt, "Female Relations"; Atwood, Community of the Cross. There are a range of perspectives regarding the Moravian understanding of the Holy Trinity and the effect that their beliefs had on practices in the Moravian Church. Fogleman argues that the Moravians radically departed from the traditional understanding of the Trinity and not only emphasized Jesus' feminine qualities but promoted "graphic portrayals of the side wound...in the form of female genitalia" (77). In Fogleman's view, this conceptualization of the Trinity fundamentally altered power structures within the church. Fogleman stresses that despite the metaphorical depiction of Jesus as female, the Moravians also stressed masculinity of his physical body. Fur rejects the notion that Moravians moved beyond the engrained patriarchy of Christianity in practice; Schutt, Smaby, and Merritt believe that the Moravians, for a least a brief period, offered women uncommon opportunities for participation in the leadership of the church.

102 Bethlehem Register, January 13, 1749, in Merritt, At the Crossroads, 108, 109. For discussion of colonists' belief in the supernatural, see David D. Hall, Worlds of Wonder, Days of Judgment: Popular Religious Belief in Early New England. (New York: Alfred A. Knopf, 1989).
} 
mission towns, Indians incorporated missionaries into traditionally Native spiritual roles, and missionaries unwittingly found themselves "acting more and more like shamans." 103

Just as Natives imposed their own meanings and traditions on Moravian interpretations of dreams, they attached new meaning to the Christian focus on the blood and body of Christ. The Moravian church held an uncommon fascination with the blood and wounds of Jesus, particularly the side wound where they believed the Holy Spirit resided until it was "released" through the wound. Indian men and women both responded to the powerful image of Christ's blood, albeit for different reasons. For men, the true test of a warrior's bravery and masculinity was his behavior in war, not only as an aggressor on the battlefield but, if captured, under torture. A show of stoicism and defiance in the face of excruciating pain revealed a man's true worth. Many Delaware men may not have been able to reconcile the Moravians' pacifist beliefs with their worldview, but the Crucifixion proved that Jesus was a spiritual figure worthy of respect. ${ }^{104}$

Delaware women also had cultural reasons to revere bloodshed. During puberty, at the time of their first menstruation girls retreated deep into the woods, isolating themselves from other members of the town and contemplating the dreams and visions that visited them. Women were seen as dangerously powerful during menstruation and not only lived apart from others but were forbidden to cook or serve food, walk on common paths, or touch medicine for fear that it would immediately lose its power. Warriors, concerned that their own power might be stripped from them, avoided any contact with menstruating women. ${ }^{105}$

\footnotetext{
103 Merritt, At the Crossroads, 109.

${ }^{104}$ Ann Little, Abraham in Arms: War and Gender in Colonial New England (Philadelphia: University of Pennsylvania Press, 2007), 35; Merritt, "Dreaming in the Savior's Blood." For further discussion of how Native Americans and colonists understood masculinity and manhood, see Little.

105 Wallace, Death and Rebirth of Seneca, 38. Jane Merritt suggests that childbirth also allowed Indian women to connect with "the power and physicality of blood to create a new religious identity that combined their own traditional values with Christian theology," At the Crossroads, 116.
} 
Indians, convinced of the inherent spiritual power of blood, flocked to the Moravians to partake in symbolic consumption of Christ's blood in the form of communion and to engage in bloodshedding of their own. The Moravians, who believed that spiritual health had profound implications for physical health, again adopted the role of shamans as they provided medical care for Christian and non-Christian Indians in the mission towns. ${ }^{106}$ Bloodletting, a common medical treatment throughout Europe and the American colonies, was an accepted cure for a range of illnesses. However, the Moravians also used bloodletting as a preventative measure and believed that regular bleeding could prevent smallpox. The Delaware, whose population had been decimated by the smallpox epidemics that periodically swept the countryside, were quick to ask for bloodletting in hopes of gaining spiritual protection. ${ }^{107}$

The Moravians' unorthodox doctrine and practices proved to be both a benefit and detriment to the mission system. While the Moravians' rejection of traditional households and their embrace of women's authority gave them an advantage over other Christian missionaries when dealing with Indian converts, it made them a target as well. Protestant theologians howled in outrage over the Moravians' violations of accepted social and gender norms, warning darkly that the "Moravian beliefs and practices represented a political threat to the state and communities" by undermining male authority. ${ }^{108}$ Although early opposition to the Moravians originated in the leadership of other denominations, by the end the Seven Years' War the main enemies of the church were found in the ranks of other white settlers in the Pennsylvania borderlands.

\footnotetext{
${ }^{106}$ Merritt, At the Crossroads; Elizabeth Fenn, Pox Americana: The Great Smallpox Epidemic of $1775-82$ (New York: Hill and Wang, 2001), 24-5.

${ }^{107}$ Merritt, At the Crossroads, 119-21.

${ }^{108}$ Fogleman, Jesus is Female, 148.
} 
As the Great Awakening invigorated Protestants throughout the Atlantic World and launched Moravian evangelical efforts around the globe, North America's Native population was experiencing what Gregory Evans Dowd has called the "Indian Great Awakening.” Nativist movements originated in the ethnically diverse villages that many Native refugees moved to as they were forced from their eastern homelands. ${ }^{109}$ In the middle of the eighteenth century, a number of Native men and women reported spiritual encounters with the Master of Life. In 1737, Conrad Weiser, a well-traveled Indian agent, heard of one such encounter while visiting a small settlement along the Susquehanna. The resident Shawnee and Onondagas informed him that one of their seers had experienced a "vision of God" in which the deity informed him the all of the wild animals had been driven "out of the country" as punishment for the Indians' engaging in the fur trade. If the Natives failed to stop exchanging hides for alcohol, the Master of Life would wipe their race "from the earth." 110 Around the same time that Weiser noted his conversation with the Shawnee and Onondaga, Presbyterian missionary David Brainerd encountered similar rhetoric among the Shawnee and Delaware. Brainerd spoke with a seer who warned his people had "grown very degenerate and corrupt." In a community plagued by disease, the man claimed that the Indians could only regain their former strength if they shunned alcohol and revived their traditional religious ceremonies.

While the encounters that Weiser and Brainerd recorded did not contain a strong political message, as the Seven Years' War approached religious revivals in Indian country began to emphasize a pan-Indian identity that sought to unite Native peoples against the encroaching

\footnotetext{
${ }^{109}$ Gregory Dowd, A Spirited Resistance: the North American Indian Struggle for Unity, 1745-1815 (Baltimore: The Johns Hopkins University Press, 1992). Dowd argues that this "Indian Great Awakening" was not so much a religious revival but rather "an awakening of the idea that, despite all the boundaries defined by politics, language, kinship, and geography, Indians did indeed share much in the way of their pasts and their present," 27.

${ }^{110}$ Paul A. W. Wallace, Conrad Weiser, 1696-1760, Friend of Colonist and Mohawk (Philadelphia: University of Pennsylvania, 1945), 88.
} 
British colonists. As Dowd notes, "attachments to the older, local, linguistic, and lineageoriented conceptions of one's people now competed with a decidedly innovative panIndianism." 111 In 1751, John Brainerd (David Brainerd's younger brother) recorded "the Indians' theory of the Races," as shared with him by a group of Delaware. According to Brainerd, "they told me that the Great God first made three men and three women, viz: the Indian, the negro, and the white man." The white man was the last to be created; God gave this youngest brother a book "and told him that he must worship him by that." Significantly, God did not provide "the Indian or negro" with such a book. Therefore, the Delaware concluded, it "could not be right for them to have a book or be in any way concerned with that way of worship." 112 Brainerd had hoped to establish a Christian mission among the Delaware, but this recitation damped his enthusiasm. More importantly, the Delaware's explanation of the races highlighted the solidifying pan-Indian identity that was coalescing in the many multi-ethnic villages in the Ohio region. Those who adopted this new identity not only conceived of "Indians" as a distinct group but viewed "whites" as a cohesive group as well - one whose interests were in direct opposition to the Indians' continued survival on the land. After discussing the creation of the three races, the Delaware shared with Brainerd their fear that "the white people were contriving a method to deprive them of their country" and "to make slaves of them and their children as they did of the negroes." Indeed, Brainerd himself was suspect. The men accused Brainerd of having been "sent on purpose to accomplish that design," and the wary Brainerd fretted that "two or three of them seemed to have resentment enough to have slain me on the spot." ${ }^{113}$

\footnotetext{
${ }^{111}$ Dowd, Spirited Resistance, 30.

112 Thomas Brainerd, The Life of John Brainerd, the Brother of David Brainerd, and His Successor as Missionary to the Indians of New Jersey (Philadelphia: Presbyterian Publication Committee, 1865), 235.

${ }^{113}$ Ibid.
} 
It would be another decade before the most well-known Delaware prophet, Neolin, received his vision from the Master of Life and advocated for a complete rejection of British trade goods and a return to traditional rituals and beliefs. But the notion that Indians and whites were distinct peoples with incompatible ways of life fed early political movements to "unite Indians against the Anglo-American menace." 114 For the Moravian missionaries and their converts, the nascent separatist movement placed Natives who chose to reside in the mission towns in a delicate position. As the violence of the Seven Years' War escalated, Christian Indians found themselves torn between accommodationist leaders who advocated working within colonial legal and social structures to protect Indians' land and interests and those who called upon Native peoples to reject European influences and recreate an Indian homeland through violence if necessary.

The religious revivals that swept through eighteenth-century America held significant implications for gender roles, family life, and power structures within both colonial and Native societies. In the midst of the evangelic fervor of the Great Awakening, the revitalized Moravian Church launched missions around the Atlantic World. Energized by their spiritual leader, Count Nicholas Zinzendorf, the Brethren created a mission system that granted women considerable power and - perhaps more than any of their contemporaries - overlooked racial and ethnic divisions. Although the Great Awakening created new opportunities for women, Indians, and blacks to exercise some degree of spiritual authority, the Moravians' radical practice of ordaining women and their communal homes and economy proved too controversial for religious leaders outside of the Moravian Church. When prominent Awakening leaders joined with members of local Lutheran and German Reformed churches in denouncing the Brethren, the missionaries turned their efforts to local Indian populations. The backlash against the Brethren during the

\footnotetext{
${ }^{114}$ Dowd, 30.
} 
years leading up to the Seven Years' War did not persuade the church to curtail women's influence within their congregations or limit their interactions with Native peoples. It did, however, paint them as outsiders to be viewed with suspicion and - at times - hostility. When the Seven Years War began, the Moravians' social position grew increasingly tenuous as a result of their marginal status.

Pennsylvania's Native peoples were also in the midst of a religious revival during the mid-eighteenth century. In the regions west of Bethlehem, deep in the Ohio River Valley, nativist movements encouraged Native peoples to overlook traditional ethnic divisions and unite in opposition to colonial interlopers. A number of Indian prophets experienced remarkably similar visions from the Master of Life, urging them to reject alcohol and distance themselves from Euro-American practices and goods. But while these revitalization movements united Native peoples west of the Alleghenies, they also divided some communities against one another. Nativist leaders worked to entice Indians affiliated with the Moravians away from the mission towns; as open conflict engulfed the borderlands, this enticement became tinged with threats of violence. By the 1750s, Delaware Indians found themselves alienated from their former allies, the Iroquois, and divided from within as nativist and accommodationist leaders argued over the best strategy to secure a Delaware homeland and security for their people. In this atmosphere of religious and political upheaval, the Delaware and the Moravians established a tentative spiritual and political alliance. But as the American colonies descended into the chaos of the Seven Years War, the Moravians and their Native converts found their fledgling alliance tested when they were targeted by both colonists and Indians. 


\section{Chapter 2 \\ “Like Sheep Among Wolves": Moravians and Delaware in the Seven Years' War}

On November 22, 1755, a young Delaware Indian named Jemmy visited his mother outside of the Moravian mission town of Bethlehem in central Pennsylvania. He quietly informed her that "great Numbers of the Allegheny, Shawanese, Mohawks, Tuscarora, and Delaware Indians ... were determined to destroy the Back Inhabitants of Pennsylvania ... and that the Moravian Settlement of Gnadenhütten would be first cut off." ${ }^{115}$ In hopes of persuading the Moravian Indians to join with their western brethren, Jemmy carried another message from the warriors:

the Gap of the Mountain was then open, and would remain so all the next Day, to give a free Passage for all the Indians in that Neighbourhood to return to the Friends at Neskopecka; but that if they refused this Invitation, they would meet with the same, nay worse Usage than the white People. ${ }^{116}$

Despite this dire warning, when the western Delaware and their allies attacked Gnadenhütten two days later they targeted the white missionaries, not the Christian Indians. Warriors killed seven white men along with three women and a child, butchered all of the cattle and horses, and burned the bodies along with every structure in town. ${ }^{117}$

Eight years later, in November 1763, residents of Philadelphia watched with a mixture of curiosity and outrage as a small train of wagons filled with Christian Delaware Indians and Moravian missionaries from the mission town of Wechquetank wound its way through the city

\footnotetext{
115 "Philadelphia, December 4," The Pennsylvania Gazette, December 4, 1755. Neskopecka was a Delaware town northwest of Gnadenhütten.

${ }^{116}$ Ibid.

117 Jane Merritt, At the Crossroads: Indians and Empires on a Mid-Atlantic Frontier, 1700-1763. (Chapel Hill: University of North Carolina Press, 2003), 185-6; Gunlog Maria Fur, A Nation of Women: Gender and Colonial Encounters Among the Delaware Indians. (Philadelphia: University of Pennsylvania Press, 2009), 53; "Philadelphia, December 4," The Pennsylvania Gazette, December 4, 1755. The town of Gnadenhütten where this attack occurred was the first Moravian mission town by that name, located along the Lehigh River in eastern Pennsylvania. The more well-known mission town of Gnadenhütten in eastern Ohio, where the infamous Gnadenhütten Massacre occurred in 1782, was not founded until 1772.
} 
streets. To Moravian missionary Bernhard Adam Grube, in the wagon alongside the Delaware converts, the group was "like sheep among the wolves." As the mob swelled, those huddled in the wagons "were much abused" and "had to listen to all revilements, mockery, and scorn." 118 The pacifist Moravian Indians who braved the jeering crowds in Philadelphia might have wished to return to their cloistered town, but Wechquetank was no longer a sanctuary. The Pennsylvania Assembly feared that the Moravian Delaware were secretly assisting the marauding Indians attacking settlers in the borderlands. They ordered the Indians to relocate to Philadelphia, where their movements could be more closely monitored. The Moravians were willing to accept internment in the wake of increasingly violent threats against them. A few short weeks later, a mob of white settlers launched an attack against Christian Indians living in Conestoga Town, killing and scalping twenty residents. ${ }^{119}$

In 1754, the world stood poised on the edge of a devastating world war, although few in Europe or America could have foreseen how the Seven Years' War (1754-1763) would reshape power structures around the globe. Deep in the Pennsylvania borderlands, Bethlehem bustled with activity, secure in its role as the seat of Moravian evangelization efforts in North America. The town functioned as a trading center and a launching site for missions to Native Americans and white settlements, while the surrounding fields ensured a steady food supply and allowed the mission to remain largely self-sufficient. But Bethlehem's vibrant success would prove to be short-lived. Between 1755 and 1763, the Delaware and Moravian alliance was tested as the Seven Years' War plunged the borderlands into bloody warfare. Native warriors threatened

\footnotetext{
118 Bernhard Adam Grube, "Diarium des Indianer-Gemeinleins in Weequetank [and Philadelphia], November 11, 1763 in Peter Silver, Our Savage Neighbors: How Indian War Transformed Early America (New York: W.W. Norton and Company, 2008), 176.

${ }^{119}$ Krista Camenzind, "Violence, Race and the Paxton Boys," in Friends and Enemies in Penn's Woods: Indians, Colonists, and the Racial Construction of Pennsylvania, ed. William A. Pencak and Daniel Richter (University Park: The Pennsylvania State University Press, 2004), 201.
} 
Bethlehem and its surrounding mission towns from the west while the colony's political power structures fractured in the east.

In the midst of war, Pennsylvania's social and political landscapes were fundamentally reshaped. The Quakers, who had maintained their grasp over the governance of the colony since William Penn had established it in 1681, found the Quaker-dominated Assembly pitted against a series of proprietary governors. Much of Pennsylvania's population turned on the ruling pacifists, laying the bloodshed in the borderlands at their feet. The backlash against Pennsylvania's Quaker political class reverberated through Moravian Bethlehem. For the German Moravians, the challenges to the Quaker-dominated Assembly threatened to undermine the influence of Moravian politicians who navigated the complicated terrain between the insular Bethlehem community and the broader world. For Native peoples who had cast their lot with the Moravians in hopes of securing their homelands and carving a protected space for themselves in the increasingly crowded borderlands, the shifting political ground called into question whether the German pacifists would prove to be the powerful political ally they had hoped.

The Seven Years' War might have been the undoing of the Delaware-Moravian political and spiritual alliance. The conflict exposed deep social and political divisions in the colony that prided itself on religious tolerance and friendly relations with Native peoples. By the time that the Treaty of Paris formally established peace in 1763, many Pennsylvanians had embraced a new racial ideology that cast all Natives as dangerous "others" and turned hostile eyes upon those known for their associations with Indian peoples. Rather than splintering the Delaware and Moravian alliance, however, the war reinforced ties between the two groups and solidified their commitment to intercultural cooperation. 
Historians have largely overlooked the role that Moravian politicians such as James Burnside, William Edmonds, and Timothy Horsfield played during this period. These men established relationships with men such as Governor Robert Morris and Benjamin Franklin and worked with both Quaker and Proprietary leaders to protect those living in and around Moravian mission towns. Their influence led to the establishment of Fort Allen, which was erected to protect white settlers but also served as a vital diplomatic meeting place for Native and colonial representatives. In spite of the Moravians' tenuous social position in eighteenth-century Pennsylvania, the colony's unique political dynamics allowed the Brethren to garner a degree of political influence that eluded them in other colonies. The Moravians' ability to protect their Native friends and allies was by no means absolute, but they proved to be savvy political actors and valuable allies to Native peoples. ${ }^{120}$

Although the Delaware-Moravian alliance survived the Seven Years' War intact, both communities struggled with internal conflicts that threatened their spiritual and diplomatic partnership. For Pennsylvania’s Moravians, the destruction of Gnadenhütten and threats of further violence from Native warriors raised serious questions about the core belief systems of the church and its missions to Native peoples. Over objections from some community members who found any form of violence to be incompatible with Christian morality, Bethlehem's leaders adapted their stance on non-violence and declared that absolute pacifism was not - and had never been - a firm tenet of the Moravian Church. This stance did little to improve the Brethren's standing in the eyes of their white neighbors, who continued to view the Moravians with

\footnotetext{
${ }^{120}$ Few works have been published on these men. Those that have, such as Whitfield J. Bell's profiles in Patriot Improvers: Biographical Sketches of Members of the American Philosophical Society, Volume II (Philadelphia: American Philosophical Society, 1999), often do little to explore the connection between their position as elected officials and their membership in the Moravian church. Katherine Carté Engel's excellent study Religion and Profit: Moravians in Early America (Philadelphia: University of Pennsylvania Press, 2011) does explore Timothy Horsfield's contributions to the Moravian church but does not examine how his political connections enabled the Moravians to support their Native allies.
} 
suspicion as they watched Indians travel to and from the mission towns. While the Moravians worked to reconcile differences within their community, the outbreak of war complicated relations between the eastern and western branches of the Delaware. Both had embraced alliance-building as a tactic to secure their future, but the Seven Years' War pitted their respective allies against one another and left the Delaware deeply divided.

When warriors from the Ohio Country attacked Gnadenhütten in the autumn of 1755 , their target was chosen for its strategic and symbolic significance. Established in 1746, Gnadenhütten was home to Mahican refugee-converts from New York as well as a number of German, English, Wampanoag, and Delaware residents. The town was perched in the Blue Mountains, along the Lehigh River's water gap. ${ }^{121}$ As a result, traders and Indian peoples frequented the town, passing through Gnadenhütten as they crossed the mountains. Both Christian affiliated and non-Christian Indians called Gnadenhütten home, living alongside one another in what Anthony F.C. Wallace described as "a little sylvan utopia." 122 The town maintained a blended economy, relying on farming, milling, and hunting to support its residents. While some Indians set about "earning money by cutting timber and conveying it to Bethlehem in floats down the Lecha," hunting remained "the chief support of the people" with "from fifteen to twenty deer and bears frequently shot in one day." ${ }^{123}$ Despite this activity, the town required "a continual supply of provisions" from Bethlehem as Gnadenhütten was "frequently visited by various companies, chiefly Delawares and Shawanose." ${ }^{124}$ Although the town was segregated the Moravian missionaries built their houses and barns alongside the chapel on the west side of

\footnotetext{
121 Today, the town of Lehighton, Pennsylvania stands over the former mission town of Gnadenhütten.

${ }^{122}$ Anthony F.C. Wallace, King of the Delawares: Teedyuscung (Philadelphia: University of Pennsylvania Press, 1949), 41.

${ }^{123}$ George Henry Loskiel, The History of the Moravian Mission Among the Indians in North America, From Its Commencement to the Present Time with a Preliminary Account of the Indians, trans. Christian Ignatius La Trobe (London: Printed for the Brethren's Society for the Furtherance of the Gospel, 1794), 264.

124 Ibid.
} 
the river while the Indians established their homes on the eastern side - the end result was a town that was perhaps the most ethnically diverse in Northampton County. ${ }^{125}$

If Amy Schutt is correct in her argument that the mid-eighteenth century Delaware strove to create an identity based on their role as "alliance-builders" and "peacemakers," then the attack on Gnadenhütten seems curious. ${ }^{126}$ But for the western Delaware, these actions were in keeping with their larger goal. By the 1730s, there were a number of Delaware towns west of Bethlehem. Several, including Connumach or Conemaugh (near present-day Johnstown), Shannopin's Town (near present-day Pittsburgh), and Kittanning (northeast of Pittsburgh) were located in the Allegheny River Valley. Other bands of Delaware migrated deeper into the Ohio River Valley, where they joined Indians from a variety of tribes - most of whom were also recent arrivals to the Ohio Country. When the Delaware moved westward, they continued to nurture their role as alliance makers. One of their most important alliances in the Ohio Country was with the Shawnee. The relationship between the Delaware and the Shawnee evolved from earlier connections between the two groups. The Delaware and Shawnee had lived alongside one another in the Susquehanna River Valley years earlier; when both were forced from their lands by encroaching settlers, they resettled along the Ohio River and renewed friendly relations. As the Seven Years' War approached, the militant Shawnee urged the Delaware to join them in their opposition to the British, declaring "let Us live and die together and let our Bones rest together." 127 The western Delaware accepted the invitation and joined their Shawnee allies in launching raids across Pennsylvania and into Maryland and Virginia. While both the western and

\footnotetext{
${ }^{125}$ Daniel Ingram, “Anxious Hospitality: Indian 'Loitering' at Fort Allen, 1756-1761” The Pennsylvania Magazine of History and Biography, 133, no. 3 (July 2009), 225.

${ }^{126}$ Amy C. Schutt, Peoples of the River Valleys: The Odyssey of the Delaware Indians (Philadelphia: University of Pennsylvania Press, 2007).

${ }^{127}$ Minutes of the Provincial Council of Pennsylvania, From the Organization to the Termination of the Proprietary Government, Vol. 6 (Harrisburg: Theo. Fenn \& Co., 1851), 37.
} 
eastern branches of the Delaware considered themselves "alliance builders," they did not necessarily agree on which groups would serve as the most strategic allies.

Nevertheless, these divisions did not sever ties between the eastern and western Delaware. On the contrary, despite the fact that the western Delaware ostensibly fought alongside the French while the eastern Delaware leaned toward the British, the western and eastern branches of the Delaware continually sought to influence one another. Indeed, some eastern Delaware eagerly participated in raids against Euro-American colonists in the borderlands having seen settlers continue to encroach upon their lands and officials do little to stem the tide. But others - particularly the Moravian Indians - noted "we have liv'd in Quiet \& Peace under the Protection of the Government of this Province" and "none of us have any hand in the abominable Murders lately committed by the Indians but abhor \& detest them."128

In 1750, Gnadenhütten became home to Teedyuscung, a Delaware leader who would gain recognition in the coming years as the "King of the Delawares," a title more reflective of colonial officials' desires than with reality. Born around 1700 in present-day Trenton, New Jersey, Teedyuscung experienced the Delaware migration from their traditional homelands to the heart of Pennsylvania and became acquainted with the Moravians soon after their arrival in Penn's colony. He joined the congregation at Gnadenhütten and sought to receive baptism from the missionaries. Soon after his arrival in the Moravian missions, Teedyuscung confronted the missionaries, voicing his "distrest that the time had not yet come, that I shall be baptized and cleansed in the blood of Christ." For their part, the Brethren were reluctant to welcome their eager convert into the fold. One described Teedyuscung as "unstable as water and like a reed

${ }^{128}$ Ibid., 748. 
shaken in the wind." ${ }^{129}$ Nonetheless, on March 12, 1750, Bishop Cammerhoff baptized Teedyuscung, noting "Today I baptized Tatiuskundt, the chief among sinners." ${ }^{130}$ After his baptism, Teedyuscung took the name Gideon and left the Delaware town of Meniolagmeka to live at Gnadenhütten, about ten miles east. The newly baptized Gideon did not come alone - his wife was baptized and took the name Elizabeth soon after arriving in Gnadenhütten; their son Tachgokanhelle and his wife Pingtus were welcomed as Amos and Justina. ${ }^{131}$

Teedyuscung's association with the Moravians proved relatively short-lived. In 1754, he led an exodus of Moravian Indians from Gnadenhütten to Wyoming, an area roughly seventy miles north of Gnadenhütten in Iroquois territory. The new settlement in Wyoming was not a formal mission community, but the Moravians did occasionally send missionaries to the region to minister to and trade with the Christian Indians. ${ }^{132}$ The community of Indians that Teedyuscung and the other Moravian-affiliated Indians joined was a multi-ethnic string of settlements that included Delawares displaced by the Walking Purchase as well as Nanticokes and Mahicans. The Iroquois who claimed the Wyoming Valley had been pushing the Moravian Indians to resettle in the region for a number of years. In 1745, Zinzendorf and other Moravian leaders had asked permission from the Onondaga council to resettle the Native converts living at the Shecomeco mission in Connecticut to Wyoming after Shecomeco became unviable "on account of the increasing animosity of the settlers" who grew hostile in the wake of King

\footnotetext{
${ }^{129}$ William C. Reichel, ed. Memorials of the Moravian Church, Vol. 1 (Philadelphia: J.B. Lippincott \& Co., 1870), 219.

${ }^{130}$ Ibid.

${ }^{131}$ Wallace, King of the Delawares, 41. Incidentally, Pingtis's sister was married to Moravian Christian Frederick Post.

${ }^{132}$ Ibid., 48-66. The Moravians called this area Wajomick; the Iroquois referred to it as Scehantowano. The missionaries who traveled to this region included David Zeisberger and Martin Mack. For additional information, see Edmund De Schweinitz, The Life and Times of David Zeisberger: The Western Pioneer and Apostle of the Indians (Philadelphia: J.B. Lippincott \& Co., 1871).
} 
George's War. ${ }^{133}$ Although the Onondaga council granted permission for the resettlement, the Native residents of Shecomeco refused to immigrate to the Wyoming Valley and eventually settled in Gnadenhütten instead. Nonetheless, the Moravians continued to foster their relationship with those in the Wyoming Valley and near Tioga, a region farther northwest near the New York border. In 1750, Bishop Cammerhoff and missionary David Zeisberger followed their Cayuga guide to Tioga and then to "Onondago, the chief town of the Six Nations." There, town council leaders declared that "the Iroquois and the Brethren on both sides of the great ocean should be indissoluble, and that two Brethren should have leave to live either in Onondago, or some other town, to learn their language." 134 Two years later, Zeisberger and missionary Gottfried Rundt returned to "dwell among" the Onondagas.

In 1753, when the newly formed Connecticut-based Susquehanna Company began surveying the Wyoming Valley, the Onondaga moved to protect their land - in part by increasing the number of Indians living in the territory. The Iroquois accordingly "called the Nantikoks from Wajomick [Wyoming] into their neighborhood, to make room for the Christian Indians" and urged those in Gnadenhütten to move northward. Writing several years later, Moravian George Henry Loskiel suggested darkly that the Iroquois' true motive was not to protect the Wyoming Valley from land-hungry New Englanders, but rather to "furnish a safe retreat from their countrymen, the Indians of Gnadenhütten, that they might more easily fall upon the white people in those parts." ${ }^{135}$ The fact that representatives from the Iroquois Nation entered into a secret agreement with the Susquehanna Land Company to sell the Wyoming Valley during the

\footnotetext{
${ }^{133}$ De Schweinitz, The Life and Times of David Zeisberger, 140. The Iroquois Nation (also known as the Six Nations) consisted of the Onondaga, Mohawk, Oneida, Cayuga, Seneca, and Tuscarora.

${ }^{134}$ Loskiel, 113.

135 Ibid., 121.
} 
Albany Conference in the summer of 1754 lends some credence to this supposition. ${ }^{136}$ Whatever their true motives, the Iroquois began pressuring those in Gnadenhütten to relocate. The missionaries fretted, fearing that removing the Christian Indians to Wyoming would tempt them away from the church but also knowing that they could not "dissuade them, lest it should be again reported, that they made slaves of their Indians, and deprived them of that free exercise of their judgement." ${ }^{137}$ Natives living in Gnadenhütten divided between those who supported the move to Wyoming and those who wished to remain closer to the Moravian brethren in Bethlehem. Eventually, sixty-five followed Teedyuscung to Wyoming, many "promising, that they would cleave unto the Lord Jesus, and remain faithful." 138

As tensions between the British, the French, and their respective allies mounted in North America, Teedyuscung and the Wyoming people increased their demands of those Indians who continued to live among the Moravians. In early 1755, Teedyuscung and Paxnous, a Shawnee leader, carried a message to Gnadenhütten from the council at Onondaga. The council declared that they "rejoice that some of the believing Indians have moved to Wajomick" but now wished to see "the remaining Mahikans and Delawares" join their kin for "a fire is kindled for them." Unlike earlier requests, however, this message warned those would not heed that "the great head, or council, will come and clear their ears with a red-hot iron.” After sharing these words, Paxnous - whose wife had been baptized by Moravian bishop August Spangenberg in Gnadenhütten - urged the Moravian missionaries "not to hinder the Indians from removing." His

\footnotetext{
136 The primary Indian negotiators who signed this deed of sale were Mohawk and did not legitimately possess the land. Like many land sales during this period, the transaction occurred in the midst of heavy drinking and possibly monetary bribes. The Onondago Council denounced the sale and the controversy led to open fighting between Delaware Indians and white settlers as well as the Pennamite-Yankee wars in the latter half of the eighteenth century. Wallace discusses the land sale in King of the Delawares, p. 60-3; the land deed is held by the University of Pittsburgh. Iroquois Land Deed, 1754, DAR.1925.13, Darlington Collection, Special Collections Department, University of Pittsburgh.

${ }^{137}$ Loskiel, 121.

${ }^{138}$ Ibid.
} 
words fell on deaf ears. ${ }^{139}$ Although the Moravians were quick to deny that they would "prohibit any one from leaving Gnadenhütten," they also reminded their converts of "the great grace they had received from God" and warned of "the imminent danger of giving ear to seducers." 140

By the autumn of 1755, French-allied "Ohio Indians" swept the Pennsylvania borderlands with increasing frequency, leaving dead bodies and burned homesteads in their wake. On November 2, Timothy Horsfield, a Moravian who was also the Justice of the Peace for Northampton County, penned a letter to Governor Morris alerting him that "the people in the parts adjacent are under frightful apprehensions of the French Indians coming down annoyed," adding that "two of the Brethren returned from a journey to [the] Susquehanna" and carried with them concerning news regarding events in the borderlands. ${ }^{141}$ Days later, Horsfield dispatched a second letter detailing the news that these two Brethren - David Zeisberger and Christian Seidle - carried back from their travels. The two men visited the Wyoming Valley after being "invited by the Indians...to preach the Gospel" and while there met with "the Shawannos [Shawnee] Chief named Pachshanos [Paxnous]" who told them that during a recent visit with "the Shamokin Indians" he learned of "three White Men who had been kill'd." Close to the bodies of the murdered settlers was "a Grave of an Indian, well dressed who had been shot." The Indians who stumbled upon this grisly scene concluded the Indian "to be a French Mohack [Mohawk]" on account of "the Hairs of his Head being pull'd out excepting a Tufft on his crown." Paxnous told Zeisberger and Siedle that the Wyoming Indians "are in great Fear of the French Indians,

\footnotetext{
${ }^{139}$ August Gottlieb Spangenberg served as Bethlehem's principle leaser from 1744-1762; aside from Zinzendorf, he was the man most responsible for shaping the town. Bethlehem. Like Zinzendorf, Spangenberg had been shaped by the Halle Pietists but later broke with the theological teachings of the group. Indeed, Spangenberg had taught at Halle until 1733, when he was fired because of concerns over his increasing radicalism and growing connection to Zinzendorf's revitalized Moravian church. Soon after joining the Unity, Spangenberg traveled to the West Indies; he later served in Georgia before settling in Pennsylvania. See Katherine Carté Engel, Religion and Profit: Moravians in Early America (Philadelphia: University of Pennsylvania Press, 2011).

${ }^{140}$ Loskiel, 125-6.

${ }^{141}$ Timothy Horsfield to Governor Robert Hunter Morris, November 2, 1755. Timothy Horsfield Papers, American Philosophical Society, Philadelphia, PA.
} 
and are also under a great concern lest the White People should think that they have had a Hand in these last Disturbances." Horsfield assured Morris that "as far as we could perceive they are all well affected toward the English And the aforesaid Chief fully intends to come here to Bethlm on a visit shortly."142

On November 22, shortly after Horsfield reported the Brethren's information to Morris, Zeisberger provided another update from the Wyoming Indians. He reported that the Indians "had observed and followed the Tracks of a considerable number of Indians in their neighborhood" and believed that these "strange Indian men" had ultimately "divided themselves and went several ways in small companies." After a brief council, the Wyoming Indians decided to send a representative to Gnadenhütten to determine "if the Indians could safely come down amongst the White People, who they were afraid would suspect them for Enemies if they should be seen several together," and if the situation was deemed secure, would dispatch "5 or 6 of their Chiefs to the Gov. to inform him of what has passed and of their Fidelity to the English." 143 As Zeisberger shared his new information, the "Indian Lad named Jemmy" was issuing his warning to the Native residents in Gnadenhütten, urging them to flee to Neskpecka. ${ }^{144}$ Meanwhile, Timothy Horsfield, James Martin, and William Parsons penned an address to "the inhabitants to Northampton County and all other well wishers of this Province.” Issued on November 24, the address opened with a solemn recognition that in the recent "time of general Distress and Calamity" many "back inhabitants have been most cruelly murdered and hundreds of them driven from their Habitations by a savage cruel and merciless Enemy." In light of these recent events, and the fact that the region was "quite destitute of any regular Force or

\footnotetext{
142 Timothy Horsfield to Governor Robert Morris, November 10, 1755. Timothy Horsfield Papers, American Philosophical Society, Philadelphia PA.

${ }^{143}$ Examination of David Zeisberger, November 22, 1755. Timothy Horsfield Papers, American Philosophical Society, Philadelphia, PA.

144 "Philadelphia, December 4," The Pennsylvania Gazette, December 4, 1755.
} 
Assistance" to defend the countryside, the leaders of Northampton proposed that the "Townships and Districts select from Time to Time a number of men to range about the mountains" in areas "most likely for the Enemies to come thro," and that a "constant Change of men may be supplied every 4 or 5 days" in hopes that "the Enemy will be kept off from the Inhabitants and you yourselves will be the better able to bear the Fatigue of this necessary Service." 145

The call to arms came too late for those in Gnadenhütten, however. Mere hours after the men at Northampton sent their address, Gnadenhütten was "attacked by the French Indians, and eleven of the inhabitants murdered." ${ }^{146}$ According to the account Horsfield sent to Governor Morris shortly after the event, the attack occurred at about " 6 o'clock while they were sitting at Supper, 14 in number" when "they heard a Dog bark very much...but on opening the Door 4 Guns were immediately discharged in upon them, which kill'd one of them immediately" while "one of the balls hit Sturgis's Chin \& set his hairs on Fire." Sturgis, surprisingly, managed to escape along with two others and fled south to Bethlehem. ${ }^{147}$ The Native inhabitants of Gnadenhütten scattered, some following the fleeing missionaries to Bethlehem while others escaped north to the Wyoming Valley. Upon their arrival in Bethlehem, the missionaries reported that the Indian party that attacked them "did not exceed $12 \ldots$ they were Delawares \& that one of them had a French match-Coat on."148

Following the massacre at Gnadenhütten, the Moravians wrote to the governor on behalf of the Christian Indians. The Natives assured the governor "none of us had any hand in the abominable murders lately committed by the Indians, but we abhor and detest them" and asked

\footnotetext{
${ }^{145}$ Address from Timothy Horsfield, James Martin, and William Parsons to the Inhabitants of Northampton County, November 24, 1755, Timothy Horsfield Papers, American Philosophical Society, Philadelphia, PA.

${ }^{146}$ Loskiel, 129. Horsfield's report to the Governor - written on November 26, two days after the attack - identifies the victims as "7 men, 3 women, and a child." See Timothy Horsfield to Governor Morris, November 26, 1755.

Timothy Horsfield Papers, American Philosophical Society, Philadelphia, PA.

${ }^{147}$ Timothy Horsfield to Governor Morris, November 26, 1755. Timothy Horsfield Papers, American Philosophical Society, Philadelphia, PA.

${ }^{148}$ Ibid.
} 
the Governor for his protection, adding "it is our desire...to put ourselves as children under the protection of this Government" and requesting "that our Honorable Governor will give us a gracious answer to this our humble petition, and provide for our future welfare and security." 149 When he replied on December 4, Morris not only assured the Indians that he believed they had no part in the "late mischief" but also informed them that the colony would erect a fort at Gnadenhütten for their protection. ${ }^{150}$ Spangenberg also wrote Governor Morris, emphasizing that the Moravian Indians should be protected as they "could do the government the greatest service." He warned Morris that Gnadenhütten was “of as great important to our government as Shamokin; for if that place not be secured...the Indians can run down... in a few hours into any part of the Forks; yea, quite down to Philadelphia." With an eye to the safety of Bethlehem, Spangenberg offered to "give of the land we have there, ten acres...in a place which can command the Lehigh and a great way on all sides" if the Government "should think well to build a fort there." A sense of urgency pervaded Spangenberg's letter, as he informed the Governor that "they must needs keep a guard there, before the houses... and mill are burned down." 151

Morris acted quickly. British Colonel Anderson and his company soon arrived in Bethlehem and then marched to Gnadenhütten along with "a number of people from other Parts of the Country," whom the Moravians supplied "with Powder \& Ball." They were greeted with the sight of smoking embers, the last remnants of houses, barns, stables, and the chapel. A small provincial company under the command of Captain William Hays set up camp in the ruins of the mission town to protect the remaining crops and what little property survived the destruction. If the western Delaware warriors had hoped to drive the Native converts away from their Moravian

\footnotetext{
149 Joseph Mortimer Levering, A History of Bethlehem, Pennsylvania: 1741-1892 (Bethlehem, PA: Times Publishing Company, 1903), 325.

${ }^{150}$ Ibid.

${ }^{151}$ Ibid.
} 
brothers and sisters, their plan was largely a failure. Delaware and Mahican converts joined their Moravian brethren and other white refugees in Bethlehem as the town struggled to meet the needs of their rapidly expanding population. As refugees from Gnadenhütten and the surrounding countryside poured into Bethlehem, Horsfield sent a plea for assistance to the Governor, writing "I hardly know what to say to your Hon. Upon these Deplorable Circumstances, our Country being in the utmost confusion imaginable, one flying here and the other there for safety." Even in the religious town, there were "men enough... who appear willing to go in Defence of themselves \& the country, but being under no command, not having Persons of Skills \& Judgement...I expect little or no Services to become by them." ${ }^{152}$ Governor Morris responded quickly, informing Horsfield that "the Law is now made granting Fifty five thousand pounds... and Mr. Penn has made a free gift of Five thousand pounds toward the defence of the province," adding "I can give no directions at present as soon as I have concluded on the measures proper to be taken to secure the Frontier, I shall make my orders publick." ${ }^{153}$ But on January 1, 1756, Delaware warriors once again swept the region. Inexperienced and unprepared, the provincial soldiers who had taken up residence in the town fell into disarray. By the end of the attack, only eighteen of Hays's seventy-two man unit remained - twenty had died in the fighting and the remainder fled in the ensuing chaos. ${ }^{154}$

In the wake of the Gnadenhütten attacks, Bethlehem hustled to prevent similar carnage in their village. Benjamin Franklin arrived to Bethlehem in early January and expressed his "surprise to find it in so good a posture of defense; the destruction of Gnadenhut had made them apprehend danger" and the Moravians had erected a stockade around the "principle buildings"

\footnotetext{
152 Timothy Horsfield to Governor Morris, November 27, 1755. Timothy Horsfield Papers, American Philosophical Society, Philadelphia, PA.

${ }^{153}$ Governor Morris to Timothy Horsfield, November 29, 1755, Timothy Horsfield Papers, American Philosophical Society.

${ }^{154}$ Ingram, 228.
} 
and "purchased a quantity of arms and ammunition from New York, and had even plac'd quantities of small paving stones between the windows of their high stone houses, for their women to throw down upon the heads of any Indians that should attempt to force into them." Franklin, well aware that the Moravians had "obtained an act of Parliament exempting them from military duties" on account of their religious beliefs, questioned Spangenberg on the Moravians' exemption as "I had suppos'd they were conscientiously scrupulous of bearing arms." Spangenberg clarified the Brethren's position, explaining that pacifism "was not one of their established principles" but that the church had received the military exemption in good faith for "at the time of their obtaining that act, it was thought to be a principle of many of their people." It was only after the outbreak of war that the church discovered "to their surprise" that strict pacifism was "adopted by but a few." While many of their white neighbors may have viewed this change of heart with open hostility, Franklin concluded rather philosophically that the Moravians were "either deceiv'd in themselves, or deceiv'd the Parliament; but common sense, aided by present danger, will sometimes be too strong for whimsical opinions." 155

It may be unfair to dismiss the Moravians' pacifism as a "whimsical opinion." But it is undeniable that the attacks on Gnadenhütten highlighted the fact that unlike other pacifist sects in Pennsylvania, the Moravian commitment to non-violence was not enshrined in church doctrine but rather relied on individual church member's freedom of conscience and thus allowed for a degree of ambiguity. Throughout the American colonies, most Christians - Protestant and Catholic - participated in the cycles of violence that plagued European colonization from within "traditions that offered theological justification for violence." 156 Only a small minority of

\footnotetext{
${ }^{155}$ Benjamin Franklin, The Autobiography of Benjamin Franklin (Boston: Houghton Mifflin \& Co., 1906), 191-2.

${ }^{156}$ Jared S. Burkholder, "Neither 'Kriegerisch nor Quakerisch: Moravians and the Question of Violence in Eighteenth-Century Pennsylvania," Journal of Moravian History 12 (2012), 144. The peace church tradition specifically rejects state-sponsored warfare; many believers reject violence even for self-defense.
} 
Christian denominations rejected the notion that warfare and Christianity could be reconciled; in eighteenth-century America, these "historic peace churches" were more influential in Pennsylvania than elsewhere in the Atlantic World. ${ }^{157}$ Although Pennsylvania's Quaker leaders were not in all cases strict pacifists, they did fight attempts to enact militia bills in the colony and used their political clout to shield pacifists even in the outbreak of war. But faced with open violence in the borderlands, the Moravian church proved that their commitment to nonviolence was not absolute.

Although the historic Unitas Fratrum had been committed to pacifism, the Moravian church that was reinvigorated under Zinzendorf did not entirely embrace the theological teachings of the former Unity. The first Brotherly Agreement, signed in 1727 on Zinzendorf's estate, did specifically prohibit the Brethren from "military service and participation in executions." ${ }^{158}$ In keeping with these prohibitions, a decade later Moravians in Georgia refused to raise arms to defend the colony against the Spanish - a stance that ultimately resulted in their fleeing Georgia for the more hospitable Pennsylvania colony. But in his later writings, Zinzendorf adopted a stance much closer to the Lutheran's just war philosophy. Published in 1753, Zinzendorf's Twenty-One Discourses Upon the Augsburg Confession reflected on the necessary use of state violence to "inflict Pain on Evil-Doers," noting "There is no Doubt of it. I myself, as great a Lover of Peace as I am, and as much as I love Mankind, yet have one Principle: Had I remained a Magistrate, I should have insisted upon it very much." ${ }^{159}$ In addition

\footnotetext{
157 The designation of "historic peace churches" did not emerge until the twentieth century and refers to the Quakers, the Church of the Brethren, and the Mennonite Church. These three denominations have for centuries remained committed to the belief that the teachings of the New Testament forbid Christians to participate in war or violence. There are, of course, denominations and individuals who embrace a strong peace ethic but fall outside of this designation.

${ }^{158}$ Burkholder, 149.

${ }^{159}$ Count N.L. Zinzendorf, trans. by F. Okeley, Twenty-One Discourses or Dissertations Upon the AugsburgConfession, Deliver'd by the Ordinary of the Brethren's Churches Before the Seminary (London: W. Bowyer, 1753), 267.
} 
to accepting that civil leaders were justified in engaging in violence so long as it was to protect society, Zinzendorf laid out the circumstances under which it was appropriate for Christians to engage in warfare: “...if I am invaded by any one in my own Country unjustly, and am like to be driven out, or disturbed in my Peace; who will blame me, if I beg God Almighty to give me the Victory; if I beg Him not to let the Invader gain the Day?"160

Part of Zinzendorf's rational rested on his belief that modern warfare was "conducted by Principles and Rules: There is a certain Law of Nations observed in War, which all Countries have tacitly agreed upon." Furthermore, he suggested that "Military Life has within these few Years become even a School for Souls, in which the Saviour has taken an opportunity of apprehending Souls who would else have never been seized for Him...but by Means of this State have been made happy and Members of his Body." And yet, Zinzendorf refrained from equating military service with Christian duty, writing

What would I prove by all this? Is it, that War is a noble, excellent, and desireable Thing... God forbid! And if we should say, our Saviour had forbid Christians, that is, all Europeans, to wage War, we should speak Nonsense. It would however be too much on the other side; to address on thus, "Thou (who art a free Christian, and by thy Condition mayst act according to thy own Choice) Wilt thou be a Soldier?" and upon his answering, No! to proceed farther, "But thou art obliged to it, else thou art no good Christian, thou art no good Citizen, thou art no Adherent of the Augustan Confession, \& c." This would be, on the other Side, an absurd Conclusion from the Premises. ${ }^{161}$

In the early days of the Seven Years' War, Spangenberg's actions fell in line with Zinzendorf's position on the use of violence even as they departed from the actions of other

\footnotetext{
${ }^{160}$ Ibid., 268.

${ }^{161}$ Ibid., 270.
} 
peace churches in the immediate area. ${ }^{162}$ As the town filled with refugees, Spangenberg directed residents to begin stockpiling their guns and ammunition. He quickly organized men into watches, which patrolled the perimeter of the town while others worked to erect palisades. While Franklin and others saw these measures as a rejection of the Moravians' self-proclaimed love of peace, Spangenberg likely saw them as means to avoid violence - a stance that remained consistent with the Moravians' beliefs and evangelical agenda. The guns carried by Moravian men patrolling the area were "meant primarily as an early warning system" and guards were encouraged to "aim for the legs" if it became necessary to shoot in order to avoid killing the enemy if at all possible. As historian Jared Burkholder suggests, Spangenberg seemed to understand his actions as "peacekeeping efforts implemented for the protection of innocent and distressed civilians" which therefore "never contradicted the Moravian peace ethic or implied lack of trust in divine protection." 163

The outbreak of violence at Gnadenhütten not only caused the Moravians to clarify their position on the use of violence (in the eyes of their neighbors, if not their congregants), but also forced them to acknowledge the increasingly important role of "town and country" congregations and of Moravian leaders whose willingness to engage "with the world" allowed those in the settlement communities to focus on mission work. While Bethlehem and its affiliated mission towns have drawn the most interest from historians in recent years, many Moravians did not live in these settlement communities. Scattered Moravian congregations appeared throughout urban

\footnotetext{
${ }^{162}$ Burkholder provides examples of Mennonites, Brethren, and Amish who chose "the path of suffering or even death rather than resistance." One of best-known examples of resolute pacifism in the face of violence in the Seven Years' War is the account of Amish man Jacob Hochstetler, who stopped his sons from seizing their guns when the family was attacked by Indians in 1757. Hochstetler and two of his sons were taken captive; his wife and two other children were killed. As Burkholder notes, Hochstetler's actions "cannot be verified aside from family tradition," but the "hagiography of Hochstetler that continues in Anabaptist circles, however, attests to the importance of strict pacifism and nonresistance for Anabaptist identity." See Burkholder, "Neither "Kriegerisch" nor "Quakerisch": Moravians and the Question of Violence in Eighteenth-Century Pennsylvania," 157-8.

${ }^{163}$ Ibid.
} 
centers such as Lancaster, Philadelphia, and New York; smaller, more rural congregations existed as well. Unlike those who resided in the settlement communities, the Brethren who worshipped in the town and country communities were, for the most part, indistinguishable from their neighbors - they lived in individual households, established professions, and remained embedded in the surrounding communities. Some of the town and country congregants aspired to move to Bethlehem or another settlement community, but many others were seemingly content to remain outside the mission towns. ${ }^{164}$

Church leaders had ambivalent feelings toward town and country congregations. As late as 1781 - years after the General Economy had ended in Bethlehem - Bishop Johann Friedrich Reichel shared his fear that those living outside of the settlements "might intirely loose the Character of living Congregations of Jesus and degenerate into a mere form of Religion." 165 Zinzendorf himself questioned the wisdom of creating a settlement that included Moravians alongside "people we do not know." ${ }^{166}$ But as the Seven Years' War tore through the borderlands, it was impossible to ignore the utility of non-settlement communities. Many of these Brethren - including political leaders such as Timothy Horsfield, William Edmonds, and James Burnside - fostered economic and political connections that allowed the Moravian settlements to thrive and provided a degree of protection during the Seven Years' War.

In 1752, Moravian Timothy Horsfield was named Justice of the Peace for Northampton County and handed responsibility for overseeing regional defense. Given that his election came prior to the outbreak of violence at Gnadenhütten - when the Moravians' pacifist leanings were largely unquestioned and their reluctance to involve themselves in colonial politics (in any

\footnotetext{
${ }^{164}$ Scott Paul Gordon, "Entangled by the World: William Henry of Lancaster and "Mixed" Living in Moravian Town and Country Congregations" Journal of Moravian History 8 (2010), 7-9.

165 "Conferences kept with the Labourers of the City and Country Congregations in Bethlehem from the $26^{\text {th }}$ to the $28^{\text {th }}$ April, 1781," 5, Moravian Archives, Bethlehem, PA, quoted in Gordon, "Entangled by the World," 9.

166 Ibid., 8.
} 
formal sense) intact - Horsfield's foray into public life is curious. Prior to the outbreak of the war, however, Horsfield's post entailed little in terms of coordinating armed defense of the colony. Instead, it seems that Horsfield's utility to the Moravians rested in his ability to navigate provincial politics. Just as Zinzendorf did not hesitate to use his political connections in Europe for the benefit of the Moravian Church even after he resigned from his formal political office, the Brethren in Pennsylvania recognized that securing political influence within the colony could further their evangelical goals.

Horsfield was well-suited for his role. Unlike most of the Moravians in Bethlehem, Horsfield was a native English speaker and thus moved naturally in circles that would have excluded many German Moravian leaders. Born in England in 1708, Horsfield immigrated to New York as a young man in 1725. Although he had been raised in the Church of England, Horsfield was neither an active church member nor, it appears, a devout believer. He was one of many swept up in the drama of the Great Awakening, however, and began reevaluating his Christian faith after hearing George Whitefield preach. In 1739, Horsfield met Moravian missionaries Peter Boehler and David Nitschmann, recently arrived from Georgia. Horsfield and his wife Mary, who had been raised Quaker, soon became active members in the transatlantic Moravian world. Their home in Long Island frequently served as "an inn for the Pilgrims who traveled from the West Indies in the service of the Savior."167

When Zinzendorf arrived in New York for the first time in 1741, he spent his first night on American soil in the Horsfield's home. Throughout the 1740s, Horsfield used his political and financial influence to smooth the Moravians' way as they established themselves in Pennsylvania. In addition to opening his home, he facilitated large cash transactions on behalf of the church, allowing them to secure the financing necessary to launch their mission efforts; in

${ }^{167}$ Timothy Horsfield, Lebenslauf, Moravian Archives Bethlehem, PA, quoted in Engel, Religion and Profit, 58. 
1743 , he intervened on behalf of the church to secure the release of three Moravian missionaries who had landed themselves in trouble with the law in Connecticut. Despite his active support of the church and its missionary efforts, Horsfield did not formally become a member of the Moravian Church until 1748. Whether this was entirely his choice or not is unclear, although there are indications that Horsfield wished to join earlier. In 1745, the Horsfields sent their two eldest children to Bethlehem for schooling. Another son joined his siblings in 1747, at which point Horsfield requested permission to move his entire family to the community but was denied. In a letter to Zinzendorf, Bethlehem's Bishop Cammerhoff wrote that "Br. Horsfield would prefer to be with his whole family in the Gemeine" but concluded "for now, however, he is still useful and needed in New York." ${ }^{168}$ It was not until 1748 that Horsfield was granted permission to join in Communion; the following year Moravian leaders allowed him and his wife to join their children in Bethlehem. ${ }^{169}$

When the Horsfields arrived in Bethlehem, they did not establish themselves as full members of the community. Rather, they occupied an ambiguous place on the outskirts of town. The town built a house for the Horsfields, where Timothy and Mary lived instead of taking their places in the choir houses. Their children continued to reside with the other students in the children's choir house, however, and Josua - a slave Horsfield had purchased in 1743 - moved into the Single Brothers' House. Therefore, unlike other members of the community, Horsfield paid an annual rent for his home and continued to pay for his children's board and schooling as he had when living in New York. ${ }^{170} \mathrm{He}$ also purchased household supplies, including food and clothing, from the communal store. Meanwhile, his house on Long Island remained open for the

\footnotetext{
${ }^{168}$ Cammerhof Letters to Zinzendorf, 1747-1748, Moravian Archives Bethlehem, PA, quoted in Engel, Religion and Profit, 59.

169 Engel, 59.

${ }^{170}$ Ibid., Josua was baptized into the church in 1750, two years after Horsfield, and lived in Bethlehem until his death in 1761. Horsfield never granted Josua his freedom.
} 
church to use as they deemed fit. Even after leaving their "town congregation" in New York to relocate to Bethlehem, the Horsfields continued to occupy the space between Bethlehem and the larger colonial world.

When Horsfield was installed as justice of the peace, Bethlehem leaders took advantage of his new position by adding a small store to his home, allowing those who traveled to Bethlehem in hopes of meeting with the county justice to purchase provisions for their trek home as well. With the outbreak of war, however, Horsfield's task of overseeing regional defense took on new meaning as he dispatched increasingly desperate letters to Governor Morris, pleading for assistance from the provincial government as attacks in the region escalated. In 1755, perhaps recognizing the benefits of establishing closer ties between Bethlehem's Moravian population and Pennsylvania's colonial government - benefits which only increased as the town struggled to deal with a spiraling refugee crisis - Moravian leaders supported another English speaking convert, William Edmonds, as he worked to secure a place in Pennsylvania's political system. William Edmonds was elected to the Pennsylvania Assembly three years after Horsfield secured his position as justice of the peace, during a period when counties in the borderlands were garnering increasing attention as they pushed for more funding and protection from the state. In many ways, Edmond's path to Bethlehem paralleled Horsfield's. Like Horsfield, Edmonds was born in England in 1708 and baptized into the Anglican Church. Trained as a tanner, Edmonds left to seek his fortunes in America in 1736, a decade after Horsfield sailed west. Although the Moravian church was active in England during the 1730s, it does not appear that Edmonds was familiar with the Moravians prior to his arrival in New York. Edmonds remained in the city and three years after immigrating married Rebecca DeBeauvios. ${ }^{171}$ The couple first became involved with the Moravian church in 1741 and quickly became active

${ }^{171}$ The couple had five children before Rebecca's death in childbirth in 1747. 
members in the congregation. Incidentally, Timothy Horsfield's family owned land adjacent to the DeBeauvios family land in Brooklyn, although it is unclear if Horsfield was directly responsible for introducing William and Rebecca to the Moravian church. William threw himself into the church and was admitted to communion in 1744; he was soon recognized as one the "spiritual leaders" of the New York City Congregation. ${ }^{172}$ Although the family remained in New York, Edmonds traveled between the city and Bethlehem on church business and the couple sent their first born son, John, to a Moravian school in Montgomery County, Pennsylvania, when the child turned three. ${ }^{173}$

In 1747 , Rebecca died in childbirth. Faced with the loss of his wife and their newborn child, William requested to move to Bethlehem. But Moravian leaders - just as they had with Horsfield - asked him to remain in New York for the time being, suggesting that he could be of more use to the church in the city. Edmonds remained in New York for several months after Rebecca's death, then placed his son and three daughters in a Moravian boarding school in Germantown and boarded the Unity's shipping vessel Irene as a crew member. He sailed to Europe, where the Irene welcomed a number of Moravians destined for Bethlehem. Upon their arrival in New York, Edmonds accompanied the Brethren from the port to Bethlehem. ${ }^{174}$ It was not until 1749 that Edmonds finally left New York City for Bethlehem, arriving in the mission town one year after Horsfield.

As the sole representative from Northampton County - a county that witnessed a number of attacks throughout the Seven Years' War - Edmonds was deeply involved in debates around provincial debt and funding. Because many committees in the Assembly required a

\footnotetext{
172 Whitfield J. Bell, Patriot Improvers: Biographical Sketches of Members of the American Philosophical Society, Volume II (Philadelphia: American Philosophical Society, 1999), 455. It is unclear if Rebecca Edmonds became a full member of the church at this time or at any point before her death.

${ }^{173}$ Ibid., 455.

${ }^{174}$ Ibid., 456.
} 
representative from each county, Edmonds received an unusually high number of committee assignments compared to his peers. During his tenure, much of his work focused on questions concerning the provincial militia. Prior to the Seven Years' War, Pennsylvania - owing to its Quaker background - did not maintain a militia. When active fighting broke out, the Assembly scrambled to create the framework necessary to create, regulate, and finance a militia in the midst of active fighting. ${ }^{175}$ Edmonds worked tirelessly, helping to draft ten bills related to establishing paper currency and paying for defense; he also labored on behalf of the Assembly to improve relations with local Indians.

When Edmonds was elected in 1755, he replaced James Burnside, who had served as Northampton's representative during the 1752 and 1754 terms. Like Horsfield and Edmonds, Burnside was a native English speaker who had left the Anglican church to join the Moravians after immigrating to the American colonies. Burnside first became acquainted with Moravians while managing an orphanage founded by George Whitefield in Savannah, Georgia. In 1743, following the death of his wife, Burnside left Georgia for Pennsylvania. When he returned to Savannah in 1744, he left his young daughter at a Moravian school in Germantown. But the following year, Burnside returned to Pennsylvania, remarried, and purchased a farm outside of Bethlehem. Like Horsfield, Burnside rejected the communal choir system and lived with his wife on the outskirts of the town. In a hard-fought election in 1752, Burnside defeated William Parsons, the founder of Easton who had the backing of Pennsylvania's Proprietary leaders. ${ }^{176}$ As a member of the Assembly, Burnside served on the finance and Indian affairs committees. In the years between Burnside's first term and Edmonds' election, the evolving dynamics of the Assembly placed the Moravians in a tenuous position. Even before the outbreak

\footnotetext{
${ }^{175}$ Ibid., 456-58.

${ }^{176}$ John Jordan, “James Burnside of Northampton County, Pennsylvania,” The Pennsylvania Magazine of History and Biography, 21, no. 1 (1897), 117-8.
} 
of violence in Pennsylvania's borderlands, tensions between the powerful Quaker contingent of the Assembly and the Proprietary party were escalating. Indeed, during the 1752 elections William Parsons warned Northampton voters that James Burnside would advance the interests of the Quakers. ${ }^{177}$ Although this message failed to resonate in 1752, Parsons did defeat Burnside the following year. His success was short-lived, as Burnside retook the seat in 1754 and was succeeded by Edmonds in 1755. But by the time that the 1756 election came about, concerns about having a Moravian in office emerged once again. Just prior to the election, the Reverend William Smith wrote to a local resident "I hope that the County would never disgrace itself by putting in any Moravian whose principles for ought we know may be Popish," adding that "They are against Defence, and you know even refused to sell Powder to Protestants tho' it is said they furnished the Indians with it... it would be a Shame to send down a Moravian at such a dangerous time." 178

In reality, the elected Moravians from Northampton County worked to secure the borderlands. While Horsfield's letters to the governor urged the state to provide resources - both financial and military - for the defense of the county, Edmonds helped draft multiple bills relating to the formation, funding, and regulating of a provincial militia. In the process, Edmonds formed relationships with Assemblymen who would prove to be important allies in the future most notably, Benjamin Franklin. Edmonds and Franklin served on several committees together during Edmonds' first term. It was this connection that brought Franklin to Bethlehem after the

\footnotetext{
177 John Jordan, "William Parsons," The Pennsylvania Magazine of History and Biography, Vol. 33 (1909), 341. Part of Parsons' animosity toward the Moravians may have been personal rather than strictly political. In the early 1740s, Parsons' German wife joined the Moravians over his strong objections; he subsequently left her and took their six children with him. Early in his political career, Parsons was known for his strong anti-German and antiMoravian positions. Later, these positions moderated - upon his death in 1757, his "good friend" Timothy Horsfield served as an executer of his will.

${ }^{178}$ William Smith to William Vernon, October 15, 1756, in William Henry Egle, ed., Notes and Queries Historical and Genealogical Chiefly Relating to Interior Pennsylvania, Vol. 3 (Harrisburg: Harrisburg Publishing Company, 1896), 538.
} 
attack on Gnadenhütten. When Franklin and Edmonds arrived in early January, Franklin wrote to the governor "We found this place fill'd with Refugees, the Workmen's Shops, and even the Cellars begin crowded with Women and Children." ${ }^{179}$ The situation continued for months - in April, a resident of Bethlehem noted "Most of our Rooms have been obliged to lodge 20 or 25 Persons and Seventy of our Indians have lived in one Small House where they had but 2 Rooms." ${ }^{180}$ The Moravians hastened to assure Governor Morris that the Indians in their midst were loyal to Pennsylvania; the governor not only accepted their assurances but announced that the colony would erect a fort at Gnadenhütten to safeguard their property. In response, Moravian leaders in Bethlehem agreed to donate ten acres of land to the province in order to erect a fort.

The site of the Gnadenhütten settlement was situated along a passage between the Blue Mountains, making it an ideal location for hostile Indians coordinating attacks east of the mountains. Soon after arriving in Bethlehem, Franklin and Edmonds set off from Bethlehem with a contingent of 130 men to build the new fort. When they arrived, they quickly set about burying the dead and organizing the outlines of the new structure. A little over a week later, Franklin christened the structure "Fort Allen." ${ }^{81}$ After spending much of January in Northampton County, Franklin and Edmonds traveled together back to Philadelphia. ${ }^{182}$ Fort Allen was intended to serve as an outpost for Pennsylvania's frontier defense. But the fort also benefitted Native peoples throughout the region and offered proof that the Moravians were worthwhile allies. The fort provided protective cover from hostile Indians - the main threat so far as Pennsylvania's authorities were concerned - but also from embittered settlers who often proved to be the more deadly threat to Native peoples as the war progressed.

\footnotetext{
${ }^{179}$ Ingram, 229.

${ }^{180}$ Letter from Unnamed Bethlehem Resident, April 1756, Timothy Horsfield Papers, American Philosophical Society, quoted in Ingram, 232.

${ }^{181}$ Ingram, 230-1.

182 Bell, 458.
} 
Fort Allen was used by both Moravian Indians and those who remained outside of the mission towns. Over the course of its relatively short lifetime, the fort served an important role as a “diplomatic way station” where Indian leaders frequently stopped as they traveled the space between the western borderlands and eastern towns such as Easton and Philadelphia. Indeed, as Daniel Ingram has argued, "instead of keeping Delawares away from the Blue Mountain region, it attracted them." ${ }^{183}$ In part, this was due the Moravians' continued interest in facilitating peaceful relations between the colonial government and the province's Native peoples.

Although the criticisms that men such as Parsons and Smith leveled against the Moravians were largely unfounded in terms of the Moravians' willingness to defend the colony, the Moravians did align with the Quakers in that they "actively sought peaceful and honest transactions with neighboring Indians." ${ }^{184}$ Both Horsfield and Edmonds worked to balance an active defense of white settlements with ongoing negotiations between colonial officials and Native peoples not allied with the French. As the Moravians in Bethlehem and Nazareth worked to protect their Native converts from increasingly hostile settlers, Edmonds used his position to maintain peaceful relations between friendly Indians and Pennsylvania's fracturing provincial government. Throughout his term, Edmonds ferried messages between the governor's office and Pennsylvania's Native peoples. In the spring on 1756, he traveled alongside a group of Indians who feared "being Hurt in the Irish settlement" as they returned home from Philadelphia; weeks later he accompanied a different group as they made the trip from Fort Allen to Bethlehem. ${ }^{185}$ The Moravians may have been motivated by their desire to save souls, but their actions had the more immediate consequence of protecting lives.

\footnotetext{
183 Ingram, 222.

184 Bell, 457.

185 Ibid., 458.
} 
Although the Moravians had facilitated the building of Fort Allen, the relationship between the fort and Bethlehem was uneasy at best. Soldiers escorted friendly Indians between Fort Allen and Bethlehem, but fort commanders also sought permission from Pennsylvania officials to seize weapons held at Bethlehem in order to more adequately arm the garrison. ${ }^{186} \mathrm{In}$ spite of their increasingly close involvement with government officials and soldiers - and their willingness to serve as an armed refuge for white settlers fleeing their homes - Bethlehem's Moravians struggled to escape rumors that they were secretly aligned with the French and their "savage" allies. Accusations that Bethlehem supplied hostile Indians with gunpowder circulated throughout the war; in 1763 the governor demanded that Edmonds provide detailed records of all of the gunpowder bought and sold by at the Bethlehem store during the previous year. ${ }^{187}$

Harder to escape was the fact that at least some baptized Moravian Indians took part in the violence aimed at white settlers. As the western branch of the Delaware launched a series of attacks from deep in the Ohio Country, the Delaware in the Wyoming Valley carefully weighed their options. In December 1755, only a few short weeks after the Gnadenhütten attack, Teedyuscung led a raid that left five white settlers dead. The roughly thirty warriors who accompanied him included two of his sons, Amos and Jacob, as well as three brothers and a nephew. Four of the men (including Teedyuscung) had been baptized by the Moravians. In addition to the five settlers who were killed, three men were taken captive and marched back to Wyoming. Just as the Moravians in Bethlehem reconsidered their pacifism in the face of direct violence, their Delaware affiliates in Wyoming divided over whether to ally themselves with their French-allied kin or to remain loyal to the English as it became apparent that continued pacifism and neutrality were becoming less viable options.

\footnotetext{
186 Ingram, 232.

${ }^{187}$ Bell, 459.
} 
By early 1756, many of the eastern Delaware had joined with their western brethren in attacking borderland communities. The Moravians sought to maintain good relations with the Indians who visited their towns, but as evidence mounted that Delaware warriors were participating in local raids some began to eye non-Christian Indians warily. Indians continued to visit Bethlehem in order to purchase good and visit the artisans as they had before the war, but at times the Moravians hesitated to fulfill their requests. On July 6, 1756, Horsfield penned a letter to the Governor requesting advice. He wrote that "We labour under much difficulty on account of these Indians - a son of Paxnous and three others from Tioga - wanting their guns repaired, and to have some powder and lead," and hastened to add that the Moravians would not do this "unless we have your Honour's express commands for it." 188 Morris replied that the Moravians should "supply them with as much as they can carry, and a small quantity of powder and lead," as it was important that they "by all means be sent very well satisfied." 189 The war forced the Moravians to walk a delicate line in their dealings with Native peoples. Bethlehem's artisan economy had been created, in part, to draw both Indians and settlers from the surrounding countryside into the town; Indians who joined the church remained in contact with friends and kin and Native peoples frequently visited the town. The problem with supplying Indians with powder and lead was twofold. Most obviously, it was possible that weapons could make their way to hostile Indians and be turned against the Bethlehem or other settlers. But there was also a very real danger of creating a backlash from settlers who witnessed the Moravians supplying powder and shot to the Indians and concluded that the Moravians were "against defense" or possibly even allied with the French. Indeed, Smith hurled this very accusation against William Edmonds during the 1756 election.

\footnotetext{
${ }^{188}$ Levering, 341.

189 Ibid.
} 
In spite of the outburst of violence in late 1755 and early 1756, Teedyuscung was soon at Fort Allen, working to establish peace and secure a formal alliance between the "friendly" Delaware and the Pennsylvanians. ${ }^{190}$ In July 1756, Indian diplomats and Pennsylvania officials gathered in Easton, about ten miles east of Bethlehem, to negotiate a treaty between the Delaware and the colony. Governor Morris appointed Edmonds to accompany him to the proceedings, undoubtedly because of Edmond's personal connections with some of the Native attendees. Upon his arrival, Morris eyed the free-flowing rum and open taverns with disdain and suggested that the proceedings be moved to Bethlehem. Teedyuscung - known for his prodigious drinking - informed Morris "I am come and will stay here," and that that he had no intention of being moved "from place to place like a Child." 191 The atmosphere at the peace talks was volatile. White settlers eyed the Native delegates with hostility; Teedyuscung did little to help matters, proudly wearing a "fine dark brown cloth Coat very much laced with Gold" that he had received from the French weeks earlier at Niagara. ${ }^{192}$ Several Delaware women who accompanied the party arrived dressed in clothes "made of Dutch Table Cloaths," which settlers concluded "they took from the People they murdered on our Frontiers." 193 Nonetheless, the parties were able to negotiate terms that held the promise of ending the violence in the borderlands.

After the talks concluded in early August, Teedyuscung stopped at Fort Allen on his way north to Wyoming, where the visiting commander happily plied his guest with liquor and cheated the Delaware out of a number of deerskins. The situation devolved rapidly. Within days, the combination of soldiers "a little merry with Liquor" and the visiting Indians resulted in a

\footnotetext{
190 Wallace, King of the Delawares, 70-86.

${ }^{191}$ Reply of Teedyuscung to Governor Morris, July 24, 1756 in Pennsylvania Archives, Series 1, Vol. 2, 722.

192 Wallace, 105.

193 Ibid.
} 
drunken melee and near mutiny. In the aftermath, Timothy Horsfield worked to smooth relations between the Delaware diplomats and the province. He caught up with the Teedyuscung, apologized for the soldiers' conduct, and promised to address the issue with the deerskins. More importantly, he convinced the outraged leader not to abandon his mission to secure a treaty between the Delaware and the province. ${ }^{194}$ By October, Teedyuscung claimed that he had persuaded the Delaware at Wyoming and Tioga to accept the treaty terms established at Easton and sent word that he would return to Fort Allen with several white captives as a goodwill gesture. Rumors of violence forced Teedyuscung to delay his arrival by a month, but by November he was in Easton meeting with the newly-elected Governor Denny and serving as a liaison between Pennsylvania officials and a contingent of Minisinks who were encamped outside of Fort Allen. ${ }^{195}$

The peace negotiations, which dragged from 1756 until the Treaty of Easton in 1758, were fraught with accusations of violence and dishonesty on both sides. Neither Teedyuscung nor the Moravians escaped the suspicion of those who believed that the Delaware were firmly allied with the French and that the Brethren were enabling their attacks throughout the borderlands; in response Teedyuscung declared that the Walking Purchase of 1737 and the Albany Treaty of 1754 were the underlying causes of Delaware hostilities. He openly charged the Pennsylvanians with fraud, explaining "All the land, extending from Tohiccon, over the Great-Mountain, to Wioming, has been taken from me by Fraud; for when I had agreed to see the Land to the old Proprietary by the Course of the River, the young Proprietaries came and got it run by a straight Course by the Coumpass, and by that Means to in double the Quantity intended

\footnotetext{
${ }^{194}$ Ingram, 240-3.

195 Robert Hunter Morris served as Pennsylvania's governor from 1754-1756; William Denny served from 17561759.
} 
to be sold." 196 The Proprietary representatives reacted in shock, with some blaming Teedyuscung's charges of fraud on Quaker meddling. ${ }^{197}$

The charge of Quaker meddling was one that was growing increasingly common in the 1750s. The sniping between proprietary officials and Quaker assemblymen highlighted a deepening divide that continued to undermine the Assembly's response to violence in the borderlands. Pennsylvania politics had been troubled for years by ongoing disagreements between Governors, who served as representatives of the Proprietors, and the Assembly, which represented "the people." In the wake of Indian attacks across the borderlands, petitions begging the Quaker-controlled Assembly to increase defensive measures and send arms flowed into Philadelphia. The Proprietary party cast blame for the violence on the Quakers, arguing that their reluctance to adequately provide for the armed defense of the colony had led to the horrific murders of dozens of white settlers. The Quaker party countered these accusations by claiming that the Delaware only attacked after the Proprietors swindled their land. ${ }^{198}$

But as the violence in Pennsylvania escalated, so did attacks on the Quaker political class and their German allies. Writing in 1755, Reverend William Smith - the provost of the College of Philadelphia - declared that the Quakers had sacrificed the lives of settlers in order to preserve their own political power. "Our Assemblies apprehend," Smith wrote "that as soon as they agree to give sufficient Sums for the regular Defence of the Country, it would strike at the Root of all their Power, as Quakers, by making a Militia-Law needful, in Time of Danger.” Smith argued that once a provincial militia was in place, the men serving "would all vote for Members of Assembly, and being dependent on their Officers, would probably be influenced by them....and

\footnotetext{
196 Julian P. Boyd, ed., Indian Treaties Printed by Benjamin Franklin, 1736-1762 (Philadelphia: Historical Society of Pennsylvania, 1938), in Wallace, 135. This statement refers to the Walking Purchase of 1737.

${ }^{197}$ Wallace suggests that the Quakers were motivated, in part, by their commercial interests and their political interests, which "demanded freedom from proprietary apron strings." See Wallace, King of the Delawares, 140-8. 198 Wallace, 140-5.
} 
thus the Quakers fear they would soon be out-voted in most Places." It was "For this Cause, they will suffer the Country to fall into the last Extremity, hoping that when it is so, our Neighbours will, for their own Sakes, defend it, without obliging them to pass a Law, which, they fear, would so soon strip them of their darling Power."199

Smith's outrage was not limited to the English-speaking Quakers. He also directed his readers to consider the danger posed by Germans in the colony. "But here it may be justly asked," Smith wrote, "By what means the Quakers, who are so small a Part of the Inhabitants, and whose Measures are so unpopular, get continually chosen into our Assemblies?" The answer, he concluded, was the influx of German voters. "Near 1800 of them voted in the County of Philadelphia, which threw the Balance on the Side of the Quakers," he claimed, and as a result, "the Quakers having found out this Secret, have ever since excluded all other Persuasions from the Assembly, constantly calling in the Germans to their Aid." ${ }^{200}$ Smith decried the "evil Genius of the Quakers," who opposed “every scheme for instructing and making Englishmen of the Germans," noting that "our Quakers, though they never swear, stick not gravely to affirm and adhere to any Falsehood whatever, provided it will support them in their darling Schemes for Power." In Smith's eyes, the most dangerous and "wealthy Sect among the Germans" were "the Mennonites, whose Principles are much the same with those of the Quakers; for they hold it unlawful to take Oaths, or bear Arms," although there was also much to fear from the "near one Fourth of the Germans supposed to be Roman Catholics, who cannot be supposed Friends to any Design for defending the Country against the French" as well as the German "Moravians, who, as they conceal their Principles, are suspected to be a dangerous People." He concluded warily

\footnotetext{
${ }^{199}$ William Smith, A Brief State of the Province of Pennsylvania, Second Edition (London: R. Griffiths, 1755), 20. ${ }^{200}$ Ibid., 29-30. Smith specifically accused Christoph Saur, the influential printer and publisher of German-language literature, of using his propaganda to drive German immigrants into a political alliance with the Quakers.
} 
that there were "also many other Sects springing up among the Germans; which it would be tedious to name, but most of them are principled against bearing Arms."201

Smith's attack on Pennsylvania’s Germans may have been hateful and hyperbolic, but it was not entirely inaccurate. Quakers and members of other pacifist sects were a minority in the colony, but they were an organized and influential minority. ${ }^{202}$ Lancaster Mennonites held meetings to discuss potential candidates while the Quakers' Philadelphia Yearly Meeting served as a caucus for members of the Assembly; between 1740 and 1776 Mennonites voted as a group in support of Quaker politicians. ${ }^{203}$ Furthermore, settlement patterns in Pennsylvania concentrated the peace church vote into a handful of counties, which allowed their votes to hold more sway than if they had been more evenly dispersed throughout the colony. ${ }^{204}$ The political alliance that emerged between the Quakers, Mennonites, Moravians, and other peace churches was based primarily on their vested interest in upholding the rights promised in William Penn's Charter of Privileges. Pennsylvania went beyond most colonies in not simply protecting the right to worship as one pleased, but in allowing "nonresistant sects to live according to conscience." Pennsylvania's Charter of Privileges, established in 1701, held that no person should be forced "to do or suffer any other Act or Thing, contrary to the religious Persuasion" and also that all were "capable (notwithstanding their other Persuasions and Practices in Point of Conscience and

\footnotetext{
${ }^{201}$ Ibid., 36-7.

202 There are no reliable figures for the exact numbers of Quakers, Mennonites, Schwenfelders, Dunkers, and Moravians living in Pennsylvania during the eighteenth century. In Conscience in Crisis, authors Richard K. MacMaster, Samuel L. Horst, and Robert F. Ulle use individual church membership records and official estimates to estimate the population. They conclude that even by "the most generous estimates," these group comprised a combined total of less than one fourth of Pennsylvania's total population. See Richard K. MacMaster, et. al, Conscience in Crisis: Mennonites and Other Peace Churches in America, 1739-1789 (Scottsdale, PA: Herald Press, 1979), 50-5.

${ }^{203}$ MacMaster, 52-3.

${ }^{204}$ Ibid., 53.
} 
Religion) to serve this Government in any capacity, both legislatively and executively." 205 This stance allowed pacifist men to hold office and exercise a degree of political power that was denied their peers living in other colonies.

Smith emerged as one of the most prolific anti-Quaker writers in the 1750s, although he was far from alone. Proprietary leaders, including then-governor Robert Morris, seized on this rhetoric in hopes of shifting political power from the Quakers to factions more friendly to the Proprietors. Morris accused the Assembly of leaving the borderlands in a defenseless state by refusing to grant him the necessary money and men to deal with the crisis. However, he failed to acknowledge the degree to which the Proprietors' resistance to paying taxes on proprietary estates contributed to the fighting between the Proprietors and the Assembly over the financing of a colonial militia or to acknowledge that the Quaker dominated Assembly was funding war efforts at unprecedented levels. ${ }^{206}$ Nonetheless, political attacks on the Quakers during these years began the slow process of transforming the polyglot inhabitants of the borderlands into "white Folks" who united to fight against Indians - regardless of the Natives' tribal or religious affiliation. A burgeoning number of printed accounts of attacks and captivity narratives condensed the diverse array of European colonists into a "single, suffering peoplehood" defined as "white." 207 Even as a more cohesive "white" identity began to form, race remained a slippery concept. Race was not necessarily understood as an innate, permanent trait and "white" was more often a political signifier than a racial one. Environment, class, and allegiance could blur racial lines; children taken captive and adopted by Indians might, quite literally, go Native.

\footnotetext{
${ }^{205}$ William Penn, The Charter of Privileges, American Philosophical Society digital history collection, https://www.amphilsoc.org/exhibits/treasures/charter.htm

${ }^{206}$ For information regarding the debates between the Proprietors and the Assembly over taxes and the financing of war efforts, see Whitfield Bell, Patriot Improvers, 457-9; for an extended discussion on attempts to discredit the Quaker political class, see Peter Silver, Our Savage Neighbors, 191-226.

${ }^{207}$ Peter Silver, Our Savage Neighbors: How Indian War Transformed Early America (New York: W.W. Norton and Company, 2008), 211, 115.
} 
Historian Peter Silver argues that pacifist groups such as the Moravians, Quakers, and other German peace churches in Pennsylvania were excluded from the new "white" identity not only because they refused to participate in armed attacks against Native people, but because they rejected the idea that all Indians were "enemies." Their allegiance was suspect, and as a result "white" settlers believed that pacifists were undermining patriarchal and racial authority and increasingly targeted them for political and physical attacks as the Seven Years' War raged on. ${ }^{208}$

In the spring of 1756, Governor Morris announced "under strong pressure from certain frontier settlers who proposed to have, at least, the grim satisfaction of turning the hazardous employment of hunting Indians...to pecuniary account" that the colony would offer scalp bounties. By their very nature, scalp bounties encouraged indiscriminate killing as the monetary reward depended only on the bounty collectors' word that the scalps they possessed were indeed those of "hostile" Indians. ${ }^{209}$ The Brethren denounced the bounties as "a new temptation to men in whose eyes one Indian was the same as another" and worried that this new policy would "again turn sinister attention to the inoffensive Indians at Bethlehem." ${ }^{210}$ When gangs of white men formed themselves into impromptu militias and commenced attacking and pillaging peaceful Indian towns, Morris denied that his proclamation sanctioned racial violence. He denounced the raiders as the "most unaccountable, headstrong People," and claimed they had "no Authority from me for what they are doing." 211

It was in the midst of these deteriorating racial and political relations that Indian representatives and government officials met in Easton yet again to continue peace negotiations.

\footnotetext{
208 Ibid.

${ }^{209}$ Ibid., 161-2. Silver points out that only eight scalp bounties were awarded to private citizens in Pennsylvania during the colonial period. Nonetheless, the introduction of scalp bounties by the Pennsylvania government fundamentally altered the context in which Indian and colonial interactions occurred.

${ }^{210}$ Levering, 340.

${ }^{211}$ Governor Hamilton to Timothy Horsfield, September 1, 1763, Horsfield Papers, American Philosophical Society, Philadelphia, quoted in Silver, 168.
} 
Both sides were divided within their ranks. Teedyuscung arrived with nearly 160 Delaware, including women and children. Over one hundred Seneca were in attendance. Members of the Proprietary Party as well as Quaker Isaac Pemberton and his allies in the Friendly Association gathered, and at Pemberton's urging, Teedyuscung demanded a clerk to produce a record of all of the proceeding for the Indians in hopes of avoiding any chicanery on the part of Pennsylvanian officials. ${ }^{212}$ If the Proprietors and the Assembly were at odds, so too were the eastern and western factions of the Delaware. Teedyuscung may have claimed the ability to convince the western Delaware to accept any peace treaty brokered at Easton, but in reality their agreement was far from assured. However, years of waging war had disrupted western Delaware communities to the point where leaders were willing to evaluate options for ending the conflict. Rather than rely on Teedyuscung, the western Delaware sent two negotiators, Pisquetomen and Keekyuscung, to Philadelphia during the summer of 1758 to outline their requirements for peace and evaluate the government's willingness to address Delaware grievances. The men insisted that they did not have the authority to reach a formal peace settlement but promised to inform western Delaware leaders of the Pennsylvania government's willingness to discuss peace terms.

When Pisquetomen and Keekyuscung left Philadelphia, they were accompanied by Moravian Christian Frederick Post, a well-known and respected missionary among the eastern Delaware. ${ }^{213}$ Post, whose mission was to convince the western Delaware to reestablish peaceful relations with the Pennsylvanians, discovered that the western Delaware were themselves deeply divided. The French-allied Ohio Indians had helped defeat British forces at the Battle of Fort Necessity in 1754 and the Battle of Monongahela in 1755. Though war weary, many were

\footnotetext{
${ }^{212}$ Wallace, 140-8.

${ }^{213}$ For a helpful discussion of the western Delaware during the Seven Years' War, see Daniel Barr, "A Road for Warriors: The Western Delaware And The Seven Years' War," Pennsylvania History: A Journal of Mid-Atlantic Studies, Vol. 73, No. 1, (Winter 2006), 1-36.
} 
convinced that General Forbes' expedition to Fort Duquesne in the autumn of 1758 posed a threat to Delaware lands in the Allegheny and Ohio valleys. They had joined with the French in hopes of securing their land; they would abandon the French only if the British could assure the Delaware that their land rights would be protected. Pisquetomen traveled with Post to Easton where the two sides finally agreed to peace terms. With the Treaty of Easton (1758), Pennsylvania - at the urging of the Quakers - agreed to repeal the Albany grant of 1754 and promised that no settlers would be permitted to reside west of the Appalachian Mountains. ${ }^{214}$

The promise of the Treaty of Easton was short-lived. Even before negotiations were taking place in the east, Indian nativism and pan-Indian spiritual renewal movements were coalescing among the disaffected Indians from various tribes that had formed inter-tribal communities deep in the Ohio Country. Just as anti-Quaker and anti-Indian literature worked to create a new "white identity" in colonial Pennsylvania, Indian revitalization movements in the mid-eighteenth century clearly delineated racial boundaries and urged all Native peoples to join together and defend their common interests.

By the end of the Seven Years' War in 1763, Pennsylvania was in the midst of a radical transformation. The racialized violence of the war exposed deep fault lines in the social and political structures of the colony once known for its religious tolerance and peaceful relations with Native peoples. When much of the population turned against the Quaker political class and embraced a new racial ideology that cast all Native peoples as dangerous "others," the backlash shook Moravian Bethlehem. For Pennsylvania’s Moravians, the war raised serious questions about the core belief systems of the church and its missions to Native peoples. Bethlehem's leaders compromised their stance on non-violence and accepted that defensive measures were necessary to protect the residents and refugees that filled the town; at the same time, they

214 Barr, 80-2. 
accommodated the beliefs of those in their community who found any form of violence to be incompatible with Christian morality. When Moravian Indians faced threats of violence, either at the hands of white settlers or other Native peoples, the missionaries worked to offer what protection they were able. The degree to which Moravians sought to nurture and use political influence in order to advance their mission efforts and protect their Native converts is often overlooked but vital for understanding why Native peoples - whether Christian or not - sought to maintain ties with the Moravians. Moravian office-holders such as James Burnside, William Edmonds, and Timothy Horsfield used their positions to establish connections with prominent leaders such as Governor Morris and Benjamin Franklin; they worked with both the Quaker political class and Proprietary leaders to address the concerns of those living in and around Bethlehem. Their political connections resulted in the building of Fort Allen outside of Bethlehem. Politicians in Philadelphia erected the fort as a means to protect white settlers, Moravians, and Christian Indians, but the site became an important diplomatic way station and meeting ground for Native peoples who were not directly affiliated with the missionaries as well. Over the course of the Seven Years' War, many Moravians who never held public office nonetheless escorted Native delegations from Fort Allen to Easton or Philadelphia, carried messages between Indian towns and Pennsylvania authorities, and appeared at treaty negotiations and diplomatic meetings. In spite of the Moravians' tenuous social position in eighteenth-century Pennsylvania, they proved to be savvy political actors and valuable allies to Native peoples. 


\section{Chapter 3 \\ A New Hope: The Ohio Country Missions}

In November 1762, James Kenny greeted a small group of Delaware Indians at his trading post outside of Fort Pitt. As Kenny visited with his guests, he learned of a Delaware prophet whose recent revelations were sweeping through the Ohio Country. The prophet Neolin, or as Kenny called him in his journal that evening, "the Imposter," had meticulously drawn a map to salvation on several deerskins that were circulating throughout the region. The map depicted the torturous path to hell that Indians who had adopted "all ye Sins and Vices. . from ye White people" would be forced to travel. Those willing to "learn to live without any Trade or Connection with ye White people," however, could travel directly to heaven. ${ }^{215}$ Perhaps most disturbing, Neolin insisted that those who followed his instructions would "in a few years, be able to drive the white people out of their country." 216

The following year, the Treaty of Paris officially ended the Seven Years' War. When he heard of the treaty, Delaware Chief Netawatwees voiced what many Native leaders felt, declaring himself "Struck dumb for a considerable time." The French had abandoned their Indian allies, and Netawatwees worried that the British had "grown too powerful \& seemd as if they would be too Strong for God himself." 217 The terms of the treaty, negotiated without any input from Native peoples, gave Britain possession of French land claims in North America including the Ohio Country. Reeling from the betrayal and stripped of their most powerful ally, the Ohio Indians mobilized to defend their land. When their effort to drive the British east of the

\footnotetext{
215 James Kenny, The Journal of James Kenny, 1761-63, ed. John W. Jordan. The Pennsylvania Magazine of History and Biography 37 (1913): 171.

216 John McCullough, "A Narrative of the Captivity of John McCullough," in A Selection of Some of the Most Interesting Narratives of Outrages, Committed by the Indians, In their Wars with the White People, ed. Archibald Loudon (Carlisle, PA: Press of A. Loudon, 1808), 272-6.

${ }^{217}$ Kenny, 187.
} 
Appalachian Mountains by force during Pontiac's Rebellion failed, Native peoples worked to develop new alliances that could ensure their future in the Ohio Country.

Years of warfare had left the Delaware deeply divided. Over the course of the 1760s, Delaware leaders worked to unite the eastern and western branches of their people physically and politically. Against a backdrop of nativist revitalization movements in the Ohio Country that urged all Native peoples to join to defend their common interests and a coalescing "white" identity among Euro-Americans in Pennsylvania that treated all Indians as dangerous outsiders, eastern Delaware moved westward to join their kin. The Moravian Delaware joined in this westward migration, but only after the Delaware Council invited the Moravians to establish a new mission town in their territory. The decision to invite missionaries to the Ohio Country enticed Moravian Indians at the expense of alienating Delaware who embraced nativist teachings. The Delaware Head Council faced a delicate task in retaining the support of western Indians while nurturing a relationship with the Moravians. For Native leaders, the DelawareMoravian alliance in the Ohio Country was grounded in political and diplomatic aims. Inviting the missionaries could reunite the eastern and western branches of the Delaware but also held the promise of providing an ally capable of helping the tribe secure a homeland and regain a voice with colonial authorities.

The Delaware's invitation to the Ohio Country came as Moravian Bethlehem struggled with its own divided community. Prior to the war, the Moravians had, for the most part, centered their missionary efforts in the regions adjacent to their main congregation in Bethlehem. ${ }^{218}$ Since their arrival in 1740, Moravians had endured attacks from religious authorities because their

\footnotetext{
218 The Shekomeko mission to the Mahican Indians in New York operated from 1740 until 1745, when the Moravians were forced to close the mission after New York passed a law that limited religious teaching to a small number of colony-approved denominations. See Rachel Wheeler, To Live Upon Hope: Mohicans and Missionaries in the Eighteenth Century Northeast (Ithaca: Cornell University Press, 2008).
} 
unorthodox beliefs about the Christian trinity and willingness to grant women leadership positions in the church challenged the prevailing gender hierarchy. ${ }^{219}$ However, it was only after the outbreak of the war that anti-Moravian fervor became widespread. Settlers in the borderlands may have perceived the Moravians as a threat to gender norms during a time when male patriarchy was being undermined as a result of the rampant violence in the borderlands, but their primary fear was that the missionaries served as a dangerous ally to potentially hostile Native Americans. This local backlash in Pennsylvania was coupled with significant changes in the international Unity, which after 1762 no longer considered missions to North America's Native Americans a high priority. Recognizing that their mission faced open animosity from their neighbors and dwindling enthusiasm from their church, Bethlehem's Moravian missionaries accepted the Delaware's invitation. ${ }^{220}$ In spite of significant internal divisions and external threats driven by an increasingly racialized landscape, Delaware Indians and Moravians chose to continue their intercultural political and spiritual partnership.

Often overlooked and dismissed as the backwater of the thriving Pennsylvania colony, the area west of Fort Pitt was home to numerous Indian tribes, British and American traders, adopted white captives, runaway slaves, and missionaries from a variety of faiths. ${ }^{221}$ The denizens of the Ohio Valley, white and Native American, maintained surprisingly close contact with the established cities on the east coast and understood themselves as actors on a national and at times global stage. During the first half of the eighteenth century, the Ohio Country

\footnotetext{
${ }^{219}$ Aaron Spencer Fogleman, Jesus is Female: Moravians and the Challenge of Radical Religion in Early America (Philadelphia: University of Pennsylvania Press, 2007).

${ }^{220}$ Historian Krista Camenzind has suggested that the violence that swept the Pennsylvania frontier during the Seven Years' War destabilized the patriarchy of the backcountry because it "interrupted men's abilities to farm, to control their land and the labor of their dependents, and to protect their dependents from an outside threat." See Krista Camenzind, "From the Holy Experiment to the Paxton Boys: Violence, Manhood and Race in Pennsylvania During the Seven Years' War" (Ph.D. Diss., University of California, San Diego, 2002), 251.

${ }^{221}$ Randolph C. Downes, Council Fires on the Upper Ohio: A Narrative of Indian Affairs in the Upper Ohio Valley until 1795 (Pittsburgh: University of Pittsburgh Press, 1940), 18-21.
} 
witnessed an influx of not only Delaware but Shawnee, Wyandot (Huron), Munsee, and Mingo (formerly Seneca and Cayuga) peoples. ${ }^{222}$ Multi-national towns emerged where tribes intermingled and established new political and military alliances. The Delaware Indians fostered this diverse mix of people, religion, and culture as a means to secure land rights and bolster their reputation as the primary "peacekeepers" and alliance-builders in the region. As factions of the Delaware attempted to nurture tribal unity, prominent leaders fostered relationships with the Moravians in hopes of reuniting the eastern and western bands of the Delaware and extending beneficial political alliances.

The Delaware-Moravian partnership in the Ohio Country came at a time when both Indians and colonists were moving toward new identities defined by race. ${ }^{223}$ When European first encountered indigenous peoples, they defined them not in racial terms but as "nonChristian." By the early 1720s, however, Indians had started describing themselves as "red" in opposition to the "white" and "black" peoples settled along the eastern seaboard. Indians came to embrace an identity of "red people" in direct response to the increasing threat posed by the British. Stories advocating the idea that the three races - red, white, and black - emerged from separate creations circulated and gained popularity during the eighteenth century. As one Delaware explained to Presbyterian John Brainerd, "God first made three men and three women, viz: the Indians, the negro, and the white man." Nancy Shoemaker notes "it is still not clear whether these expressions meant that Indians believed themselves racially, or physiologically and innately, different from Europeans," but the idea that common skin color determined

\footnotetext{
${ }^{222}$ Richard White, The Middle Ground: Indians, Empires, and Republics in the Great Lakes Region, 1650-1815 (New York: Cambridge University Press, 1991), 188.

${ }^{223}$ Nancy Shoemaker suggests that a "white" identity first emerged in major slaveholding regions; the Northeast and Mid-Atlantic colonists lagged behind their Southern peers. The first racial label to appear consistently was "black" or "negro," which was commonplace by the early 1700s. See Nancy Shoemaker, A Strange Likeness: Becoming Red and White in Eighteenth-Century North America (New York: Oxford University Press, 2004), 125-40.
} 
common interests (broadly defined) gained acceptance. ${ }^{224}$ This concept formed the basis for nativist resistant movements in the Ohio Country. The first major pan-Indian war effort came in 1763, when Indians energized by the teachings of the Delaware prophet Neolin launched what became known as Pontiac's Rebellion.

Around 1760, Neolin received a visitation from the Master of Life. The deity shared with him how the Indians could purge themselves of the social ills introduced by the White people and regain their land and prosperity. Afterward, Neolin traveled the region around Lake Erie, sharing his vision and urging Native peoples to unite. Neolin's message differed from those of earlier prophets not in content but in degree, and he soon emerged as the spiritual leader of the nascent Indian revitalization movements. Prophets in the 1740s and 1750s had suggested that whites and Indians were created separately by the Master of Life and urged Indians to shun alcohol and avoid dependence on white trade. But whereas earlier prophets spoke to their immediate village or tribe, Neolin envisioned a pan-Indian movement that rejected all white influences. Deerskins with pictorial explanations of Neolin's teachings passed from the Ohio Country to the Great Lakes region and Illinois Country. Neolin was also unique in that he outlined a specific seven-year plan for ending white influence in Indian country. The course to returning to traditional Native society included a sustained period of ritual fasting and purging, required boys to learn how to use a bow and arrow, and dictated that elderly men and women eat only corn. Only after seven years would all trade be cut off, thus removing lingering remnants of white influence. ${ }^{225}$ By 1763 , Native peoples throughout the Ohio Valley had enacted the first

\footnotetext{
${ }^{224}$ Ibid., 132.

${ }^{225}$ Gregory Dowd, War Under Heaven: Pontiac, the Indian Nations, and the British Empire. (Baltimore: The Johns Hopkins University Press, 2002), 94-105; Alfred Cave, Prophets of the Great Spirit (Lincoln: University of Nebraska Press, 2006), 22-6; David Dixon, Never Come to Peace Again, 95-98; Lee Irwin, Coming Down From Above: Prophecy, Resistance, and Renewal in Native American Religions (Norman: University of Oklahoma Press, 2008), 125-33. Dowd argues that Neolin's prophecy differentiated between the British and the French and called only to end British influence in Native culture.
} 
steps toward fulfilling Neolin's vision. The Delaware Council began "to train their boys in the traditional arts of warfare" and the Ohio Delaware and Shawnee ritually consumed an emetic "black drink" designed to purify their bodies and society. ${ }^{226}$

Neolin's vision itself demonstrated the futility in attempting to remove all white influence from Native society. Neolin incorporated Christian notions of heaven and hell into his teachings, warning that Indians who failed to live up to the Master of Life's standards would "undergo a degree of Punishment, before they are admitted into heaven," including torture with "a flame of fire." ${ }^{227} \mathrm{He}$ also urged followers to practice "abstinence from carnal knowledge of the different sexes" and denounced adultery and the practice of polygamy. ${ }^{228}$ Considering that premarital and extramarital sexual relations were broadly accepted in Delaware culture and the matrilineal society traditionally dissolved marriages with ease, Neolin's dictates represented the incorporation of white mores, rather than an embrace of traditional norms.

The Prophet's teachings were affected by Christian and nativist beliefs, but they also reflected a decidedly Delaware agenda. In keeping with the Delaware's commitment to position themselves as alliance builders and peacekeepers, Neolin called for peace between Indian peoples. The most important message conveyed in his vision from the Master of Life was "Do not fight among yourselves;" to demonstrate this unity, Indians were to "exchange greetings and proffer the left hand which is nearest the heart." 229 It is possible that Neolin's vision was successful in uniting the peoples of the Ohio Country in part because he was Delaware - a people known for building connections between nations. The Delaware were also recognized as a "special source of visionaries who offered guidance to Indians in time of trouble." During the

\footnotetext{
${ }^{226}$ Dowd, 33-5.

227 John McCullough, in Loudon, Most Interesting Narratives, 275.

${ }^{228}$ Ibid., 273.

${ }^{229}$ Milo Milton Quaife, ed. The Siege of Detroit in 1763: The Journal of Pontiac's Conspiracy and John Rutherfurd's Narrative of a Captivity (Chicago: R.R. Donnelley \& Sons Company, 1958), 16.
} 
early eighteenth century, a number of Delaware prophets rose to prominence for their messages that promised to heal the ills plaguing Indian society. ${ }^{230}$

There was some ambiguity in Neolin's vision and its subsequent interpretation. While the Master of Life warned against drunkenness and reprimanded the Indians for their dependency on white trade goods, he did not require total abstinence from alcohol and told Neolin "I do not forbid you to permit among you the children of your Father [the French]; I love them...and I supply their wants and all they give you." ${ }^{231}$ Yet at the same time, the Master of Life queried "Can ye not live without them? I know that those whom ye call the children of your Great Father [the French] supply your needs, but if ye were not evil, as ye are, you could surely do without them." He continued, "Ye could live as ye did before knowing them...Did ye not live by the bow and arrow?" Adherents of Neolin's vision also seemed to view the French differently. Iroquois and Shawnee warriors urged other Indians to "take up the Hatchet against the White People, without distinction, for all their Skin was of one Color and the Indians of a Nother, and if the Six Nations wou'd strike the French, they would strike the English." 232

Indians' actions during Pontiac's Rebellion suggest that they ultimately defined "White People" along ethnic and political lines rather than racial ones. When the Ottawa war chief Pontiac adopted and militarized Neolin's message in 1763, he directed his anger at the British, calling on his allies to "exterminate from our lands this nation which seeks only to destroy us," continuing “...the English sell us goods twice as dear as the French do, and their goods do not last... when we wish to set out for our winter camps they do not want to give us any credit as our

\footnotetext{
${ }^{230}$ Amy C. Schutt, Peoples of the River Valleys: The Odyssey of the Delaware Indians (Philadelphia: University of Pennsylvania Press, 2007), 120.

${ }^{231}$ Robert Navarre, Journal of Pontiac's Conspiracy, trans. R. Clyde Ford (Detroit: Clarence Monroe Burton, 1910), quoted in Dixon, Never Come to Peace Again, 97.

232 "At a Conference Held at Fort Augusta, October 18, 1756, The Speech of Ogagradarisha," Minutes of the Provincial Council of Pennsylvania, From the Organization to the Termination of the Proprietary Government, Vol. VII (Harrisburg: Theo. Fenn \& Company, 1851), 299.
} 
brothers, the French, do." ${ }^{233}$ Throughout 1763 and 1764, a pan-Indian confederation lashed out at British forts in the Ohio and Illinois countries while maintaining good relations with the remaining French residents. In spite of some decisive victories early on, Native forces faltered in the face of disease, supply shortages, and a fractured base. Although pan-Indian religious and political movements sought to unite Native peoples, they had the paradoxical effect of "dividing their own peoples from within." 234 Gregory Dowd argues that such divisions actually extended the life of nativist movements. A defeat in the face of a dedicated, united movement would have suggested that the prophecy was false; so long as Native communities remained divided between accommodationists and nativists, a defeat could be explained away as "the consequence of other Indians' misdeeds." 235 Even at the height of the fighting, some Indians worked with the British to provide intelligence and other assistance. As losses mounted, Native peoples slowly made peace with the British. By the autumn of 1764, Pontiac's Rebellion was effectively over, although Pontiac did not formally surrender until July 1766.

Interestingly, the man whose vision helped unite Indians in the Ohio and Illinois countries received another visit from the Master of Life in January 1765, after the pan-Indian confederation had largely collapsed. Neolin reported that in this vision, the Master of Life called on the Delaware to negotiate with the British, but only through the Quakers. Neolin's request for Quaker representatives went unanswered; the Delaware signed a peace treaty in April 1765 in spite of "great Confusion amongst themselves and without any order in their Council."236 Nonetheless, Neolin's vision and willingness to negotiate only through the Quakers is significant. At the very least, it demonstrates that Native peoples deemed the Quakers more

\footnotetext{
${ }^{233}$ Quaife, 22.

${ }^{234}$ Dowd, A Spirited Resistance, xviii.

235 Ibid., 37.

${ }^{236}$ George Croghan to Thomas Gage, May 12, 1765, Gage Papers, in Dowd, Spirited Resistance, 36.
} 
trustworthy than other colonial representatives. This is unsurprising, given the Delaware's long history with the Quakers. It also suggests that Native spiritual and political leaders may have viewed the Quakers just as Pennsylvania's angry settlers did - as a people exempt from "white" identity.

During Pontiac's Rebellion, the western Delaware fought alongside the Shawnee, Wyandot, and a number of other nations to drive settlers back across the Appalachian Mountains even as their eastern kin turned to colonial officials and allies for protection. The Moravians rallied to protect their converts, but the violence of Pontiac's Rebellion, following so closely on heels of the Seven Years' War, triggered another onslaught of anti-Moravian protest. With religious leaders no longer heading the anti-Moravian fervor, the movement became more widespread and violent. Unlike the protests in the 1740s, those in the 1760s were due to the Moravians' close association with Native peoples. Moravian opponents ignored doctrinal disagreements and centered their rage on the Moravians' protection of Indians. For many settlers, the violence of the Seven Years' War had erased the distinction between "friendly" and hostile Indians, even as elite politicians in Philadelphia hastened to strengthen relationships with "friendly" Indians. To those who had been victimized during the war, all Natives now fell into the category of "enemy," and the Moravians were thereby complicit in the murder of white settlers throughout the borderlands.

In the fall of 1763, weeks after western Indians successfully captured British forts west of the Appalachians, approximately two hundred Moravian Delaware Indians from mission settlements outside of Bethlehem left for Philadelphia after a series of visits from white neighbors who threatened to "fall upon us in the Night \& kill us all." 237 Provincial officials

\footnotetext{
${ }^{237}$ Bernhard Adam Grube to Timothy Horsfield, October 13, 1763, Horsfield Papers, American Philosophical Society, in Silver, 138.
} 
organized the relocation, perhaps motivated more by the testimony of provincial Indian commissioners who claimed that the Moravians were smuggling weapons to the militant western Delaware than concern for the Christians' safety. Although there was little evidence to substantiate these rumors, officials could be forgiven their suspicions in light of the permeable boundaries between the mission towns and surrounding Indian villages. After angry mobs blocked the Moravians' entry into the city, Philadelphia's sheriff arranged for the Indians to stay at Province Island, a city-owned farm a few miles outside of town. ${ }^{238}$

Remaining in the Pennsylvania borderlands as the Seven Years' War gave way to Pontiac's Rebellion was an increasingly risky proposition. Weeks after the Bethlehem Indians retreated to Philadelphia, a group of approximately fifty white men attacked a community of Christian Conestoga Indians sixty miles west of the city. Only eight Indians were home at the time, but they were killed, scalped and mutilated and their houses torched. The remaining Conestogas, who had been visiting Lancaster for the day, were taken into protective custody. A few days later, raiders broke into the Lancaster jailhouse, murdering the six adults and eight children inside. Moravian William Henry described the carnage, reporting a "man's head and feet had been chopped off with a tomahawk." Nearby, "men, women and children spread about the prison yard' shot, scalped, hackled, and cut to pieces." ${ }^{239}$ The Paxton Boys, as the murderers became known, declared that the Moravian Indians sheltering in Philadelphia would soon meet the same fate.

The Conestoga Massacre exemplified the deadly consequences of the new racial ideology taking hold in Pennsylvania. Yet this incident also highlights the fact that, as Scott Gordon states, "while racial prejudice influenced the groups that the Paxton Boys considered enemies, their

\footnotetext{
${ }^{238}$ Silver, 174-8; a description of Province Island can be found in the Pennsylvania Gazette, March 28, 1781.

${ }^{239}$ I. Daniel Rupp, History of Lancaster County: To Which is Prefixed a Brief Sketch of the Early History of Pennsylvania (Lancaster PA: Published by Gilbert Hills, 1844), 358-59.
} 
category of enemy was not limited by race." ${ }^{240}$ After slaughtering the Conestoga Indians, the Paxton Boys jubilantly "paraded around town, publicizing their feat." Then several of the men, "high spirited and full of themselves," rode to the Moravian settlement community of Litiz where they galloped through the streets firing their weapons and shouting "God damn you, Moravians." ${ }^{241}$ Two days after the attack, an "Irishman" told Litiz innkeeper Andreas Horn that "after the Irish protestors (he indicated about 400 men) have carried out their plans in Philadelphia, they want to go to Bethlehem, and destroy the Indian town."242 Matthäus Hehl, minister of the Litiz congregation, anxiously warned the Bethlehem congregation that "if such a mad mob should get the idea of coming to Bethlehem to pay some sort of unpleasant visit...you wouldn't be able to respond to such an unexpected attack any faster than a rumor can fly." He urged the residents to "be prepared and armed in prayer" as the "Paxtown group is evilly disposed towards Bethlehem."243

The Paxton Boys' march to Philadelphia was cut short in Germantown when a delegation led by Benjamin Franklin convinced the mob that colonial officials would consider their grievances, but the diplomatic solution did little to assuage Moravians' alarm. Their fear proved well founded when men returning from Germantown boasted that "they had killed all the Indians, five Quakers, and two Moravians in Philadelphia."244 The Moravians who heard these rumors had no way of knowing that they were untrue; given the horror at Conestoga, there was no reason to dismiss reports of further bloodshed.

\footnotetext{
${ }^{240}$ Scott Paul Gordon, "The Paxton Boys and the Moravians: Terror and Faith in the Pennsylvania Backcountry" Journal of Moravian History 14, no. 2, 2014, 119.

${ }^{241}$ Matthäus Hehl to Bethlehem, December 29, 1763, Records of the Indian Missions, 1742-1898, Moravian Archives, Bethlehem PA, quoted in Gordon, "Paxton Boys and Moravians," 120.

242 Ibid., 138.

${ }^{243}$ Ibid., 140.

${ }^{244}$ Peter Boehler to Nathanael Seidel, February 27, 1764, Letters from Lancaster, Moravian Archives Bethlehem, PA, quoted in Gordon, "Paxton Boys and Moravians," 142.
} 
If there is little question that the Paxton Boys and their sympathizers viewed all Indians as enemies, thus creating a distinct racialized "other," it is less clear whether Euro-American colonists had embraced an understanding of their own racial unity. Conceptions of race were in flux and race was not yet understood as an innate, biological trait. But just as Indians adopted the label "red people," the term "white people" was becoming broadly accepted as a distinct category. "White people" in the mid-eighteenth century may have been united primarily by shared experience and culture, but the definition was characterized by race and ethnicity as well. Following the Conestoga Massacre, Benjamin Franklin accused the attackers of acting from racial motivations:

In Europe, if the French, who are White-People, should injure the Dutch, are they to revenge it on the English, because they too are White People? The only Crime of these poor Wretches seems to have been, that they had reddish brown Skin, and black Hair; and some People of that Sort, it seems, had murdered some of our Relations. ${ }^{245}$

Elite politicians far removed from the borderlands may have recoiled from such logic, but settlers who had experienced violence firsthand were not concerned with determining which Indians posed a threat and which did not. The Indians' "reddish brown Skin and black Hair" offered all the proof needed to define them as enemies. Franklin's statement condemns racially motivated violence but also accepts the premise of racial identity. His "White People" do not merely share a political identity - in this hypothetical, the French and English occupy the same racial space. The Indians who joined Pontiac's Rebellion may have maintained a distinction between French and British "white people," but Pennsylvania's settlers increasingly failed to acknowledge differences among the Indians.

\footnotetext{
${ }^{245}$ Benjamin Franklin, A Narrative of the Late Massacres, in Lancaster County, of a Number of Indians, Friends of this Province, By Persons Unknown, With Some Observations on the Same (Philadelphia: Franklin and Hall, 1764), 13.
} 
As the Moravian Indians hovered anxiously outside of Philadelphia, a mixture of Christian and non-Christian eastern Delaware headed west to the Ohio Country under the leadership of Delaware chief Netawatwees. ${ }^{246}$ Over the course of his life, Netawatwees had witnessed his people being forced inexorably westward. He fought alongside the French during the Seven Years' War and banded with his western brethren during Pontiac's Rebellion. As war raged across the land, Netawatwees urged the eastern Delaware to move to the Ohio Valley in hopes of reuniting the eastern and western branches of the Delaware and securing the safety of all. Netawatwees did not trust the British and feared that they had "grown too powerful," but after the British routed the strongest pan-Indian alliance North America had ever seen it was abundantly clear that if the Delaware wished to secure their land, they would have to work with the British to do so. ${ }^{247}$

The close of the Seven Years' War left both the Delaware and the Moravians struggling to recreate their communities. In the Ohio Country, Netawatwees and other Delaware leaders sculpted a fragile unity based on their drive to secure legal recognition of their land and establish their own political sovereignty. Gaining a legal title to the land that the Delaware occupied in the Ohio Valley was motivated not merely by the desire for security from encroaching white settlers, but by the larger goal of ending Delaware dependence on the Iroquois. ${ }^{248}$ The decision to invite the Moravians to the Muskingum Valley was highly contested and largely motivated by the Council's desire to unite Christian Delaware living in the eastern Moravian missions with their

\footnotetext{
${ }^{246}$ Netawatwees actively worked to reestablish Delaware unity in the 1760s and 1770s. Although he had been associated with militant western forces in the 1750s, his views moderated as the Seven Years' War drew to a close and he began to see a degree of cultural accommodation as acceptable so long as it supported to ultimate goal of Delaware unity. Netawatwees invited the Moravians to the Muskingum Valley in 1772. For further discussion, see Michael McConnell, A Country Between: the Upper Ohio Valley and Its Peoples, 1724-1774 (Lincoln: University of Nebraska Press, 1992).

${ }^{247}$ Colin Calloway, The Scratch of a Pen: 1763 and the Transformation of North America (New York: Oxford University Press, 2006), 66-77.

${ }^{248}$ Hermann Wellenreuther, "White Eyes and the Delaware's Vision of an Indian State," Pennsylvania History 68, no. 2 (Spring 2001): 139-61.
} 
western kin. ${ }^{249}$ From the Delaware Council's standpoint, the ultimate goal was the consolidation of the Delaware people and the establishment of a protected homeland. Delaware men and women who had been baptized in the eastern missions were reluctant to leave their "teachers," however, which forced the Council to consider how they would deal with the Brethren. Allowing the Moravians to establish missions by the western Delaware town would reunite the two branches, but nativists resisted any call to bring Christian missionaries to the region.

Jesuit missionaries had been active in the Ohio Country since the seventeenth century, but Protestant efforts to evangelize the region were relatively limited until the end of the Seven Years' War. When the Catholic presence diminished as Jesuits retreated from Wyandot and Seneca villages and concentrated their efforts in the scattered French settlements west of the Ohio river valley, Protestant leaders began to show an interest in the area. The previous lack of Protestant influence in the region was due in part to the French Catholic influence in the area, but the more significant limitation was Native peoples' distrust (and at times hostility) toward English Protestant missionaries. This wariness only grew in the middle of the eighteenth century as displaced Indians retreated from the east coast to the Ohio Country. For those who had seen their homelands washed away by a tide of European immigrants, the presence of missionaries carried an aura of foreboding. ${ }^{250}$ Their fear was not misplaced. When Baptist minister David Jones visited the Ohio Country in 1773, he noted the rich farmland and opined that "the land is indeed good, but at present... is in the hands of fools" as the Indians were "so lazy, that they are commonly needy, and must be more so, if they do not cultivate their land." Jones and Delaware leaders regarding one another with mutual disdain. He concluded that the Delaware "from the greatest to the least, seem mercenary and excessively greedy of gain"; their "virtues are but few,

\footnotetext{
${ }^{249}$ Wellenreuther and Wessel, introduction to Zeisberger, The Moravian Mission Diaries, 51.

${ }^{250}$ Ibid., 46-50.
} 
their vices near the same with other Indians." ${ }^{251}$ Netawatwees and the Grand Council greeted Jones cordially but stymied his efforts to deliver a sermon. Netawatwees' son Killbuck attempted to explain to Jones why the Delaware were resistant to his efforts and those of other missionaries, noting they also "would not have Presbyterians, because their ministers went to war against them, and therefore did not like to be taught by them now, who were before killing them." 252 He also shared that the Delaware were concerned that white ministers held "some design of enslaving them" as a "highland officer" had taken "one of their women as his wife, and went with her in Maryland" where "he sold her a slave like a negro... and they never saw the squaw afterwards." ${ }^{253}$ Upon hearing these concerns, Jones concluded "it was plain that Indian prejudice was very great and unreasonable." 254

In spite of nativist leaders' very legitimate concerns, the Grand Council eventually agreed to invite the Moravians to build a mission town on their land. Convincing the Christian Delaware to move westward may have been the driving motivation, but there were other potential benefits as well. Inviting the Moravians to establish religious communities in the region demonstrated to colonial officials that the Delaware were happy to become permanent, peaceful neighbors.

Furthermore, the Moravians were appealing because they expressly forbade their missionaries to involve themselves with political matters or war efforts and required them to work toward peace and reconciliation between tribes. Both stances were particularly helpful to leaders struggling to counteract the widespread hatred towards Indians among the white settlers, maintain tribal unity, and negotiate for Delaware independence from the Iroquois; they also dovetailed with the

\footnotetext{
${ }^{251}$ David Jones, A Journal of Two Visits Made to Some Nations of Indians on the West Side of the River Ohio, In the Years 1772 and 1773 (Burlington, N.J.: Isaac Collins, 1774), 100, 106.

${ }^{252}$ Ibid., 98.

${ }^{253}$ Ibid., 101.

${ }^{254}$ Ibid., 98.
} 
Delaware's dedication to cementing their own identity as "peacekeepers" in the Ohio Country. ${ }^{255}$

Perhaps most importantly, the Moravians had proved themselves valuable allies to eastern

Delaware during recent conflicts. The Moravians' had been unable to shelter their Indian

converts from all harm during the Seven Years' War, but they nevertheless proved themselves

important allies in a swiftly changing world. The political landscape in Pennsylvania may have

shifted power from the Quakers and their coalition of the colonial Assembly, but they still

maintained some grip on the reins of power.

The Delaware had a long established relationship with Pennsylvania's colonial leaders.

From its founding in 1681 until the outbreak of conflict in the 1750s, Pennsylvania's colonial

government had maintained friendly terms with the Delaware, often favoring the tribe over other

native groups. This preferential treatment was largely due to the fact that William Penn's earliest

interactions with the Native Americans in North America were with the Delaware, who were

inclined to maintain peaceful terms with the white newcomers and sold Penn the massive tract of land on which Pennsylvania was founded. ${ }^{256}$ With William Penn's death in 1718, however, the dynamics of Pennsylvania's proprietary government shifted. The elder Penn may have sought to establish open and trusting relationships with Indians in alliance with Pennsylvania, but his descendants had no such priorities. John and Thomas Penn, land rich but cash poor and deeply in debt, sought to assert their proprietary rights in order to regain their financial stability and were

\footnotetext{
${ }^{255}$ Wellenreuther, "White Eyes and the Delaware's Vision of an Indian State," 59.

${ }^{256}$ See Amy Schutt, Peoples of the River Valleys and Richard Grimes, "The Emergence and Decline of the Delaware Indian Nation in Western Pennsylvania and the Ohio Country, 1730-1795," (Ph.D. Diss, West Virginia University, 2005), 8-9. Grimes argues that the Iroquois-Pennsylvania alliance of 1732 led the Delaware to recognize the necessity of developing a unified national front. Rather than weakening the Delaware, the loss of their land proved to be the catalyst for establishing a national identity among those Delaware who moved into western Pennsylvania. By the late 1740s, the western Delaware were not only capable of taking action as a unified body but had found a new middle ground from which they openly challenged their subjugation to the Iroquois confederacy. The nascent national identity that the Delaware forged in the mid-eighteenth century proved too fragile to withstand the onslaught of violence that the Revolution brought to the Ohio Valley, however, and by the end of the eighteenth century the political unity, identity and autonomy had crumbled.
} 
willing to step outside the moral boundaries their father had created to do so if necessary. ${ }^{257}$ Native peoples suddenly found themselves engaged in a power struggle amongst themselves for influence in Pennsylvania's new political landscape.

Within months of William Penn's death, the Penn brothers and provincial leaders of Pennsylvania began cultivating alliances with the powerful Iroquois Nation. In 1736, the governor of Pennsylvania signed a treaty with the Iroquois that ensured Iroquois war parties safe passage through the colony in exchange for the Iroquois using their political might (and military skill) to prevent western tribes from attacking the Pennsylvania borderlands from the Ohio region. Significantly for the Delaware, the agreement explicitly granted the Iroquois jurisdiction over all other Indians residing in Pennsylvania, a stipulation that the Delaware viewed as a betrayal by both sides. ${ }^{258}$ From the proprietors' perspective, there were several advantages to aligning with the Iroquois, not least of which was countering French influence with the Nation. But more significant in the short run was the Iroquois' willingness to sell land that did not strictly belong to them. A series of shadowy land deals between the Iroquois and the colony allowed the Pennsylvanians to swindle the Delaware out of vast tracts of land, effectively dispossessing the Delaware while maintaining a veneer of legitimacy. ${ }^{259}$

Divisions between Native American tribes in Pennsylvania deepened as the Iroquois repeatedly sold land belonging to the Delaware, Shawnee, and Susquehanna Indians residing on the borderlands of the colony. The Delaware's struggle to renegotiate their position in the colony ultimately led to internal divisions. It was in the 1740 s that several bands moved to the Ohio

\footnotetext{
${ }^{257}$ David L. Preston, "Squatters, Indians, Proprietary Government, and Land in the Susquehanna Valley," in Friends and Enemies in Penn's Woods: Indians, Colonists, and the Racial Construction of Pennsylvania, ed. William A. Pencek and Daniel Richter (University Park: The Pennsylvania State University Press, 2004), 183.

${ }^{258}$ Grimes, 22-5.

${ }^{259}$ James Merrell, Into the American Woods: Negotiators on the Pennsylvania Frontier (New York: W.W. Norton \& Company, 1999), 35-6.
} 
Country; the western bands' continued disillusion with the colonists' willingness to negotiate fairly and anger over the Iroquois' manipulation helped spur them toward French alliances as the peaceful colony transformed into a battleground during the Seven Years' War. ${ }^{260}$ The bands of Delaware that remained in the east sought to repair relationships with the colonial government and accommodate the white settlers that increasingly surrounded them. They no longer had a connection to the proprietors as they had under William Penn, but the Delaware nurtured relationships with Quakers in the Pennsylvania Assembly. When the Moravians arrived in 1740 and settled in the hotly contested "forks of the Delaware" region, the Delaware Indians recognized that an alliance with the Moravians held the possibility of strengthening ties to the white community and Pennsylvania government. The eastern Delaware hoped to regain the privileged status they had once enjoyed with the colonial government and thereby secure their land from white settlement and avoid having it sold out from under them by the Iroquois. In the meantime, they used the Moravians as a shield for their land. Settlers who had no qualms pushing onto Native land refrained from stealing land claimed by Euro-American Christians; in their eagerness to convert Native peoples, the Moravians were willing to help even those Indians not affiliated with their church. In 1742, the Moravians offered a compromise to the nonMoravian Indian Captain John:

We are willing that the said Captain continue his Habitation on our Land, and that he enjoy the Use of all the Land he has hitherto cleared. We will also consider him as our Tenant, but without any Payment of Rent to us, because the said Place has been a Settlement of his Forefathers; and we will not drive any body from such a Right. ${ }^{261}$

\footnotetext{
${ }^{260}$ Pencak, ix-xii. Although the Seneca were members of the Iroquois Confederacy, the western bands of the Seneca operated largely independently and were more inclined to oppose the British than work with them to secure land. ${ }^{261}$ Diarium von Bethlehem, June 22/July 3, 1742, Van Pelt Library, University of Pennsylvania, in Merritt, At the Crossroads, 97.
} 
The Moravians, having purchased the contested land from the colonial proprietor, clearly felt that they were now the rightful owners of Captain John's home. Nonetheless, their willingness to compromise with Captain John rather than forcibly remove him, which would have been within their legal rights, allowed the Delaware to retain some control over his property. Native Americans also worked within the Moravian mission system to acquire new plots of land. In an effort to convince Delaware men to practice agriculture, the Moravians gave men individual plots to farm. They also granted single or widowed women land to cultivate. Because these lands were commonly seen as an extension of the Moravian mission complex, white settlers did not infringe on their boundaries. ${ }^{262}$

Delaware leaders in the Ohio Country did not intend to replicate the circumstances of the eastern mission towns. The missionaries would reside on Native land at the invitation of the Council; presumably, nativist leaders who agreed to allow the Moravians to establish missions by their towns did so knowing that any invitation could be withdrawn once Delaware lands were legally protected and a Moravian alliance was no longer needed. But in the short-term, a Delaware-Moravians partnership could prove useful. The Moravians could provide a defense against the land hungry speculators and settlers who trickled into the area while the Delaware worked to formally secure their land. Western Delaware leaders were well aware of the Moravians' political connections in Philadelphia, their role in establishing Fort Allen during the Seven Years' War, and their efforts to protect their Indian converts. There were also personal relationships between certain influential Delawares and Moravians. Netawatwees' grandson, Gelelemind, had forged a friendship with the prominent Moravian convert William Henry, a wealthy Lancaster politician. Expanding the networks that already linked the Delaware and the Moravians seemed a promising means of advancing the Delaware's political agenda.

${ }^{262}$ Merritt, At the Crossroads, 152. 
William Henry would prove to be an influential figure in the Moravian Church and in Pennsylvania's political scene during the latter half of the eighteenth century. The origins of his relationship with Gelelemind remain murky. Henry family histories credited William Henry with saving Gelelemind's life on a battlefield in 1755. According to the most popular account, Gelelemind, a young warrior at the time, was captured by British soldiers who were "about to dispatch him with their bayonets" when Henry intervened "at the risk of his own life" and rescued the warrior "from the infuriated soldiers." In gratitude, Gelelemind took the name William Henry as "no greater honor could be conferred." 263 A different version of the story claims that the two men met outside Pittsburgh in the summer of 1775; yet another maintains that the two men met for the first time in 1784 . There is no doubt that Gelelemind and Henry met before David Zeisberger established the first Moravian mission in the Ohio Country. In 1771, Edward Shippen wrote to his son Joseph "the day before yesterday arrived here, two Indians, Killbuck \& his son [Gelelemind], from Ohio, with a letter...from Newcomer King of the Delaware Nation." During that visit, "Brother Henry spent lots of time with them" as they "knew Br. Zeisberger and praised his efforts to acquaint the Indians with their Creator and Redeemer." ${ }^{264}$ Gelelemind called on Henry's home in Philadelphia during a visit in 1774; the two men met again in 1784, when Gelelemind appeared before Congress in hopes of securing Delaware land claims. The circumstances of the two men's meeting are unclear, but it is undeniable that there was strong connection. During Gelelemind's adult life he was known

\footnotetext{
${ }^{263}$ Francis Jordon, The Life of William Henry, of Lancaster, Pennsylvania, 1729-1786, Patriot, Military Officer, Inventor of the Steamboat (Lancaster, PA: New Era Printing Company, 1910), 8-11. Jordan was William Henry's great-grandson. His book, published as a history, relies heavily on family tradition. In many cases, there is no other evidence to verify his account; there is some question as to whether Henry had even joined war efforts prior to 1756. See Scott Paul Gordon's articles "The Killbuck-Henry Legend Revisited, Part 1" The Jacobsburg Record, 37 no. 1 (February 2010): 1-7 and "The Killbuck-Henry Legend Revisited, Part 2" The Jacobsburg Record, 37 no. 3 (April 2010): 1-11 for detailed discussion of the Killbuck-Henry story. The story had been recounted by other family members before Jordon's account, with some discrepancies in the telling.

${ }^{264}$ Gordon, “The Killbuck-Henry Legend, Part 1", 3.
} 
variously as Killbuck, John Killbuck, Captain William Henry, and William Henry Killbuck. When he was baptized in 1789 , Gelelemind formally took the name William Henry.

Although William Henry was himself a recent convert to the Moravian church, he was one of the church's most valuable members, if also one of its most controversial. Born in Chester County, Pennsylvania, on May 19, 1729, Henry was raised in the local Presbyterian Church and apprenticed as a gunsmith in Lancaster after his father died. He may have marched with General Braddock's failed expedition to Fort Duquesne in 1755; he joined the Provincial forces as an armourer in 1756 and participated in General Forbes expedition in the same capacity in $1758 .^{265}$ Henry steadily worked his way into Lancaster society. After he married Ann Wood in 1756, the couple invited the then-unknown painter Benjamin West to live with them and became the young artist's first patrons. In 1759, he was elected Lancaster's Justice of the Peace. By 1760, Henry had aligned himself closely with Thomas Penn and the Proprietary party. He rubbed shoulders with Lancaster's elite politicians, serving on the original board of directors of the Juliana Library Company and renting a pew in Lancaster's affluent St. James Church. William Smith, the minister who vehemently denounced the Quakers and worked against the election of William Edmonds during the Seven Years' War, occasionally preached at St. James; joining Henry in the pews were Edward Shippen, James Burd, Thomas Barton and many others from Lancaster society. During this period, Henry also went into partnership with businessman Joseph Simon. Simon had been funding ventures into the western fur trade since the 1740s, shipping goods from Lancaster west in exchange for furs that were then sent to New York and London. When Henry

\footnotetext{
${ }^{265}$ Whitfield J. Bell, Patriot Improvers: Biographical Sketches of Members of the American Philosophical Society, Volume II (Philadelphia: American Philosophical Society, 1999). Family lore holds that Henry marched with Braddock in 1755 but no evidence corroborates that story.
} 
joined him, Joseph Simon's Lancaster store had earned a reputation for being "the distributing center for beaver and other furs from the Ohio Valley.”266

William Henry, wealthy and connected, was not a man likely to join the Moravian church. But Henry was a spiritually troubled man. In his Lebenslauf, he recounted an incident in 1758 in which he witnessed his "neighbor's child lying as a corpse," and his "heart was so filled that I could not restrain my tears." ${ }^{267}$ Henry left the child's funeral and found "a place where no one would observe me, threw myself on my face and said to the dear God: I do not know You...I am quite ignorant of your ways. But grant me one thing: an open ear and a thoughtful heart so that if You want to teach me something, I will be able to understand You and distinguish Your Voice from all others." ${ }^{268}$ In 1762, Henry and his wife left St. James Anglican church to attend the local Quaker meeting. The following year, the couple befriended their neighbors, Albrecht and Mary Russmeyer, who were members of Lancaster's Moravian congregation. William's wife Ann was eager to join the Moravians, but Henry was reluctant. He later wrote "I reproached the dear God with all that I had already had to endure, since I had left and gone to the Quakers and [said] that it would be much worse if I were to join this despised people, surely he would not want me to prostrate myself again." ${ }^{269}$ Nonetheless, the Henrys were received into the Moravian church in 1764 and formally became members on June $23,1765 .{ }^{270}$

Unlike Bethlehem, Lancaster's Moravian church was not a settlement congregation. Members did not reside in sex-segregation choir houses and continued to engage with their local community. Therefore, William Henry continued his active involvement in Lancaster politics

\footnotetext{
${ }^{266}$ Gordon, "William Henry of Lancaster," 10-15; B. and M. Gratz, Merchants in Philadelphia (Jefferson City, MO: Hugh Stevens Printing Co., 1916), 34.

${ }^{267}$ Lebenslauf of William Henry of Lancaster, trans. by Rev. Roy Ledbetter, quoted in Gordon, "Entangled by the World," 45.

${ }^{268}$ Ibid., 46.

${ }^{269}$ Ibid., 50.

${ }^{270}$ They were not permitted to take communion until 1767, however, as the Lot rejected them several times.
} 
and business. Scott Paul Gordon suggests that Henry "may have insulated himself from the potential consequences of joining the Moravians by making himself economically indispensable in town." ${ }^{271}$ His gunsmith business hummed along. Henry and Simon's Lancaster store "imported a bewildering variety of merchandise from England" and as their wealth accumulated the two men served "as a source of credit for many of Lancaster's leading citizens." ${ }^{272}$ Whatever they may have whispered behind his back, Lancaster's elite recognized their financial dependence on William Henry. ${ }^{273}$

William Henry's partnership with Joseph Simon connected him - and, indirectly, the Moravians - to the fur-rich Ohio Country years before the missionaries arrived in the region. Simon wasn't his only connection, however. By 1766, William Henry's youngest brother, Moses Henry, was living at Fort Pitt and working as a gunsmith for Bynton, Warton, and Morgan, a Philadelphia trading house whose networks crisscrossed Indian country, stretching from Fort Pitt to Detroit. ${ }^{274}$ Within a few short years, Moses had left Fort Pitt to settle in the Shawnee town of Chillicothe as part of Simon's extensive trading network in the Ohio Country. Moses "married a white woman, who was captivated so young that she speaks the language as well as any Indian,” and no doubt benefitted Henry's prospects in Indian country. ${ }^{275}$ Henry did well for himself. In 1773, the minister David Jones met Henry in Chillicothe and noted that he "lived in a comfortable manner, having plenty of good beef, pork, milk, \& c."276

The Henry household in Chillicothe appears to have served a number of functions. It was a trading post, a meeting place for Native peoples and Euro-Americans, and a lodging space for

\footnotetext{
${ }^{271}$ Gordon, "Entangled by the World," 24.

${ }^{272}$ Ibid.

${ }^{273}$ Henry's business partner Joseph Simon was Jewish, making both men religious outsiders.

${ }^{274}$ Scott Paul Gordon, "The Henrys and the West: Moses Henry, Gunsmith and Indian Agent," The Jacobsburg Record 35 no. 1 (March 2008): 1.

${ }^{275}$ David Jones, Journal of Two Visits, 55-6.

${ }^{276}$ Ibid., 56.
} 
visitors. Moses repaired guns, dispatched letters, and kept his shelves stocked with European goods and foodstuffs. Many Shawnee had strong nativist leanings and traders were often viewed with hostility in the local villages, yet Moses Henry appears to have established friendly relations with his Native neighbors. When an Indian threated the ever unpopular David Jones with a knife, Jones retreated to the Henry household for protection; after a later incident in which Jones encountered another Indian who appeared "the very harbinger of death itself," Ann Henry and her "foster-mother" from "the time of her captivity" chastised the man who was then "very glad to find the door." ${ }^{277}$ Moses Henry wasn't the only man in his family to venture westward. In 1773, his brother John joined him in Chillicothe before continuing on to Detroit. Incidentally, William Henry's son John Joseph joined his uncle on this trip, illustrating the associations that Moravian William Henry maintained with his non-Moravian brothers. ${ }^{278}$ William Henry had personal and economic ties to the Ohio Country prior to joining the Moravian church; after he became a member of the Lancaster congregation, he would gain religious and political ties as well.

While Indians in the Ohio Country struggled to adapt to a new political and racial landscape honed by brutal warfare, Bethlehem was also undergoing a revolutionary social evolution that fundamentally altered the thriving community. During the Seven Years' War, the Moravian church experienced a number of upheavals, both theologically and socially, which radically transformed Bethlehem's social, cultural, and economic structures. While most of these changes were initiated by Moravian leaders in Europe and only indirectly connected to the Seven Years' War, the racialized violence that the war enflamed in the colonies also drove significant change in Bethlehem. As a result, the community more closely integrated into the surrounding

\footnotetext{
277 Ibid., 51.

${ }^{278}$ Gordon, "The Henrys and the West," 10.
} 
society and experienced religious decline. A number of historians have worked to explain how this reorganization of Bethlehem affected its residents, but few have looked beyond Bethlehem to consider how the dissolution of communal systems and values shaped Moravian missionary efforts to Native peoples.

In 1762, as Neolin traversed the Ohio Country sharing his vision for the future, the international Moravian Unity dissolved Bethlehem's General Economy in an effort to solve the fiscal issues plaguing the community. This decision was handed down from leaders of the Moravian Unity in Europe, not those in Bethlehem, who were faced with heavy debts and unforgiving creditors. Trouble had been brewing for years, as the economic well-being of the Moravian enterprise and Zinzendorf's personal finances had been tangled since the rebirth of the Unity in 1722. The Unity's impressive growth led them to establish a number of far-flung missions. In addition to Bethlehem, the church built entire towns in North Carolina, Germany, Britain, and the Netherlands. While Zinzendorf was generous in donating his own resources to the church, his social standing also allowed the Moravians to borrow vast sums of money nearly all of it from Zinzendorf's wealthy family and friends. As a result, the Moravian movement was financed by an ever-increasing mountain of debt. Initially, most of this borrowing occurred in Europe. But in 1748, Johann and Juliana Nitschmann replaced Spangenberg in overseeing Bethlehem and launched a building phase that expanded the town at the expense of producing goods and farming. With so many resources being devoted to building, the Brethren were forced to purchase food and other basic necessities outside of the community. By the time 
that Spangenberg resumed his leadership role in 1751, Bethlehem's outstanding loans had grown to staggering levels. ${ }^{279}$

Under Spangenberg's watch, Bethlehem managed to stabilize and within two years was once again financially solvent. Meanwhile, in Europe, the Unity scrambled to get their finances in order. By 1755, the Unity had instituted austerity measures and established a payment system designed to manage the burgeoning debt. This plan entailed dividing the church's liabilities among all Moravian communities, with contributions determined by each area's ability to pay. Bethlehem was suddenly faced with new expenses just as they managed to curtail their own spending. This may not have constituted a crisis had it occurred a few years earlier, but by the end of 1755 Bethlehem was struggling to support hundreds of refugees who crowded into the town in hopes of escaping the rampant violence in the borderlands. Although the Moravians did receive some financial help from the provincial government and Quakers sympathetic to their mission, most of the burden of caring for the displaced refugees fell onto the General Economy. Writing in October 1756, nearly a year after the attacks on Gnadenhütten, Spangenberg noted that the Native converts "have been diligent...they have dug, chopped wood, mown grass, and done what they could, and for their earnings, they have acquired clothing other necessities...It is not enough, however, because there are many widows and orphans among them that still need help." ${ }^{280}$ As the population of Bethlehem continued to grow, the communal system became increasingly untenable - and Bethlehem proved unable to contribute satisfactory payments to the Unity's debt.

\footnotetext{
${ }^{279}$ Smaby, Transformation of Moravian Bethlehem: From Communal Mission to Family Economy (Philadelphia: University of Pennsylvania Press, 1988), 26-35; Katherine Carté Engel, Religion and Profit: Moravians in Early America (Philadelphia: University of Pennsylvania Press, 2011), 150-60.

280 "Lieben Brüder u. Schwestern," October 12, 1756, Spangenberg Papers, Moravian Archives Bethlehem, PA, in Engel, 144.
} 
By 1756, the Seven Years' War reached far beyond the Pennsylvania borderlands.

Fighting in Europe disrupted harvests and stalled commerce around the Atlantic world. In Saxony, troops marched across the countryside. The Unity's plans for achieving financial stability unraveled as both Bethlehem and the international church failed to meet their pecuniary commitments. Letters between Unity leaders and Bethlehem leaders crossed the Atlantic, each side pleading poverty and asking the other for funds. Years passed without a resolution in sight. Then, on May 9, 1760, Count Zinzendorf died. ${ }^{281}$

For nearly four decades, Zinzendorf had been the spiritual leader, theological authority, and financial backbone of the Moravian church. Unsurprisingly, his death threw the church into disarray. But it also cleared the way for the fundamental reorganization of a denomination that was foundering. As part of the restructuring, Unity leaders in Herrnhut elevated their authority over the international church and prioritized achieving economic stability. Soon after Zinzendorf's death, Herrnhut enacted changes that would reshape Bethlehem's economy and religious mission. First, they ordered that the General Economy be dissolved. They determined that in this case, the overall financial health of the Moravian enterprise trumped the religious mission of the pilgrim town. With the dissolution of the General Economy, the choir system was partially disassembled. Married couples were now expected to live in nuclear households, support themselves financially, and care for their children. This complicated process began in 1762 but took years to complete, as eliminating the communal economy entailed restructuring the social and familial structures of the town as well. Transitioning to nuclear households required new houses to replace the choir homes. Few members of the community had the resources necessary to obtain their own land or house, which required the town to launch into a

\footnotetext{
${ }^{281}$ Ibid., 159. Zinzendorf's wife, Anna Nitschmann, died on August 19, 1760. Nitschmann was Zinzendorf's second wife and a prominent leader in the Moravian church (much more so than Zinzendorf's first wife had ever been). Had she lived, it is possible that the reorganization of the church would have taken a different path.
} 
flurry of building and remodeling. Several larger buildings were converted into apartments with individual kitchens and neat rows of small houses were erected along new streets. Those who moved into these homes paid rent to the church, which retained ownership of all the property in Bethlehem. The Single Brothers and Single Sisters continued to live in the choir house, but were now expected to pay rent from the wages that they received for their work. ${ }^{282}$

When the community transitioned to nuclear households, they also adapted to a new system of wage labor. Many of the most established (and profitable) businesses remained under church ownership. The artisans - now employees of the church - received wages based on their experience, skills, and the profitability of the business. ${ }^{283}$ Profits from these church-owned enterprises went toward paying down the Unity's debt and supporting ongoing missionary work. Many artisans, particularly those whose trades did not require substantial infrastructure, established private businesses. It was not uncommon for these "independent" artisans to pay interest and annual fees to the church, however, as the church had initially invested the capital needed to establish the business. ${ }^{284}$

The dissolution of the General Economy had social consequences that the Unity leadership had likely not considered. Although Bethlehem had never eliminated - nor attempted to eliminate - social hierarchies, the nature of the General Economy maintained relative gender and class equality. With the move toward a market economy, however, segments of the population found themselves able to accumulate wealth while others struggled to make ends meets. As a means to motivate master craftsmen to increase the annual profits of church-owned

\footnotetext{
282 Smaby, 105-10; Engel 170-5.

${ }^{283}$ Engel points out that at this point, leaders "chose to reward some labor more highly than others, just as the larger Atlantic economy valued the work of skilled adult white males more than it did any other category of workers." See Religion and Profit, 174.

${ }^{284}$ Ibid., 175-80.
} 
businesses, leaders instituted a profit-sharing system - but only for master craftsmen overseeing the business, not the journeymen or other workers who labored under their direction.

The Single Sisters were hit particularly hard as the result of the new system. Despite the role that women played in the leadership of the Moravian church and in mission work, even under the communal system labor had been divided along traditional gender lines. Women did not train to be artisans; men did not prepare meals or launder clothing. Therefore, the Single Sisters suddenly found themselves in a confined economic role with few opportunities for paid employment. Many took in laundry or sewing, others spun fabric and cleaned homes. Eventually, the Single Sisters' Choir organized a spinning operation that became the core industry supporting the choir house. But compared to the General Economy, which was premised on the belief that all work was equally important in supporting the mission, the new market-based system that clearly elevated certain professions (and individuals) over others constituted a dramatic change in the social and gender dynamics of Bethlehem. ${ }^{285}$

The second change that Unity leaders in Herrnhut dictated was initially less dramatic but ultimately played a significant role in changing the nature of the settlement community. In 1762, the same year that Unity leaders dissolved the General Economy, they created a new council called the Mission Diacony and tasked with overseeing global missionary endeavors. From this point forward, the Mission Diacony selected and trained missionaries, supervised the financial aspects of new missions, and oversaw the logistics of transporting missionaries to and from their posts. In reviewing the worldwide scope of the Brethren's evangelical work, efforts to reach North American Indians no longer ranked a high priority to the council. The Seven Years' War and ensuing racial tensions had disrupted Indian missions in Pennsylvania for nearly a decade and Bethlehem was no longer the crown jewel that it once was. Not only were Bethlehem's

\footnotetext{
${ }^{285}$ See Smaby and Engel for greater discussion of these changes.
} 
missions now on the periphery of the Moravian Church's international system, but the Diacony also ended the communication system that required all correspondence from the Caribbean missions to pass through Bethlehem in route to Herrnhut. Together, these two changes - the dissolution of the General Economy and reorganization of international Moravian missions altered the character of Moravian Bethlehem and led those still dedicated to evangelical work among Native Americans to consider how to proceed in light of the new dynamics in Pennsylvania and within the Unity. ${ }^{286}$

Historian Beverley Smaby argues that as a result of the dissolution of the General Economy, Bethlehem became more integrated into the surrounding society and experienced religious decline; the communal economic system had functioned as the support structure of the church and its religious beliefs and without them, the settlement stagnated. In the years following the end of the General Economy, marriage rates fell by $44 \%$ and the birthrate dropped by $39 \%$; Bethlehem's population fell by $20 \%$ in 5 years. ${ }^{287}$ Smaby argues that the Unity's cultural logic "insisted that a communal economic and social system was justified only if the cultural focus was spiritual...since Bethlehem's religious work was to be discontinued, the communal system had to be abandoned as well." 288 To give credit where it is due, the dissolution of the General Economy did make Bethlehem more profitable, as the Unity's leadership had intended. But it also changed not only the economic and social structure of the Moravians but their understandings of how people should live and the values a community should hold. The simple, communal life had encouraged religious commitment, but the ability to accumulate wealth

\footnotetext{
${ }^{286}$ It is important to note that although these two changes did significantly alter Bethlehem's character as a pilgrim town, this shift in focus unfolded over several years. Because the church retained ownership of nearly all the property within the town's borders, the church also determined who could move into Bethlehem. In effect, Bethlehem remained "closed" to outsiders for decades, thus preserving some of the unique characteristics of the mission town. See Engel, pages 171-3.

${ }^{287}$ Smaby, 239.

${ }^{288}$ Ibid., 242.
} 
inspired financial success - a boon for the financial well-being of the church, but a detriment to religious commitment.

In the spring of 1771, Head Council of the Delaware at Gekelemukpechünk invited the Moravians to settle in the Muskingum River Valley and establish a mission to the Native peoples there. Since the collapse of the Native missions in and around Bethlehem, Moravian missionaries had edged westward and continued their evangelical efforts despite the church's wavering support. But divisions between Delaware peoples plagued their efforts. In 1767, David Zeisberger established a mission on the Allegheny River near Tionesta Creek at the invitation of the Delaware leader Allemewi. The mission was forced to relocate soon thereafter, as the Delaware preacher Wangomen and his followers proved openly hostile to the missionaries' presence. Two years later, Johann Roth founded a mission in Schechschiquanünk, which met a similar fate. In 1770, the Moravians accepted an invitation from the Delaware council at Kuskuski, but their settlement continued to draw the ire of Wangomen. The situation further deteriorated as settlers began to trickle into the areas surrounding Kuskuski, land that had been exchanged by representatives of the Iroquois at Fort Stanwix in 1768.

It was in this atmosphere that the Moravians decided to accept the offer from Gekelemukpechünk. To the Moravian Provincial Helpers' Conference, the invitation from the Delaware Head Council offered hope that these mission congregations would avoid the fate of their earlier efforts in the region. If the missions received protection from the Head Council, perhaps they could avoid the tensions brought about by nativist leaders. If this is what motivated the Moravians to accept the Council's offer, they were to be disappointed in the coming years. Missionary David Zeisberger founded the first mission in 1772, which was settled by Delaware converts and christened Schoenbrunn. A few months later, the Moravians established a second 
mission, Gnadenhütten, roughly ten miles away from Schoenbrunn. Gnadenhütten became home to Mahican converts who had recently migrated to the region. Four years later, at the request of Delaware Chief Netawatwees and the General Council at Gekelemukpechünk, the Lichtenau mission was founded near the new Delaware head town of Goschachgünk. ${ }^{289}$

The missionaries who traveled to the Ohio Country had a long history of ministering to Native peoples and were dedicated to continuing their work, even as the international Unity no longer prioritized Indian missions in North America. The demise of the General Economy shaped the new towns in the Muskingum Valley. Zeisberger and his fellow missionaries were responsible for supporting themselves. They worked alongside their converts erecting houses, plowing fields, and harvesting crops. In keeping with early efforts (and unlike many other denominations), the Moravians distinguished themselves by sending missionaries who were trained artisans rather than theologians. The primary purpose of training missionaries in a variety of trades was to enable them to construct settlements and maintain a reasonable level of selfsufficiency in the backcountry. Johann Roth was a locksmith, Johann Schmick a joiner, and Johann Jungmann a miller. ${ }^{290}$

In the years between the close of the Seven Years' War the establishment of the Ohio missions, both Delaware and Moravian communities experienced significant turmoil. The new towns held promise for the future, although Delaware leaders and Moravian missionaries did not share the same vision. Delaware leaders remained committed to the Delaware-Moravian

\footnotetext{
${ }^{289}$ Wellenreuther and Wessel, introduction to Zeisberger, The Moravian Mission Diaries, 59. Although the Moravians preached that all converts were part of a Christian family that overlooked ethnic differences, their Indian converts insisted on segregated villages. In 1777, when the mission towns feared attack from British-allied warriors, the Mahicans in Gnadenhütten moved to Lichtenau, the Delaware mission town that enjoyed the protection of nonChristian Delaware warriors in adjacent Goschachgünk. After tensions eased, the Moravians returned to Gnadenhütten. Schoenbrunn was given up when Lichtenau was settled in 1776, but reestablished in 1779. Similarly, Lichtenau was abandoned and the new community of Salem created in 1780.

${ }^{290}$ Before joining the Moravian Church, Schmick was a Lutheran pastor. As such, he was a trained theologian. In the Moravian mission field, however, his education was not as significant as his trade skills.
} 
intercultural alliance in hopes that their connections with the Moravians would garner political power and secure American recognition of an Indian homeland, which in turn would foster Delaware unity. For the Moravians, the new mission towns offered a chance to continue their evangelical mission removed from the dangers posed by hostile white settlers and nativist Indians leaders. When the Delaware invited the Moravians to establish mission towns along the Muskingum, neither the Indians nor the Moravians could have foreseen the new war on the horizon. The American Revolution undermined the Delaware's efforts to unite their people and carve a place for themselves in the west and the Moravians once again found their missions fraught with violence. The coming war would test the Delaware-Moravian intercultural alliance and the Moravian's political influence as both sides worked to protect themselves and their friends in the Ohio Country. 


\section{Chapter 4 \\ "Our Own Flesh and Blood": Alliance and Kinship in the Ohio Country}

On a warm morning in the summer of 1777 , the former Delaware war captain Isaac

Glikhicken rose to his feet and addressed the assembled Wyandot warriors:

Our teachers are not only our friends; we consider them our own flesh and blood and love them as such. Since we are your Cousins, our request and desire of you, Uncles, is that you also consider our teachers part of your own body as your Cousins, because we are of one body with them and cannot be separated from them. ${ }^{291}$

Isaac's declaration came as the Wyandot war party readied for battle. Once again, war had spread across North America, this time as the British colonies turned against their mother country. As the conflict engulfed the western tip of Pennsylvania and tore into the Ohio Valley, Native peoples carefully evaluated their options. The Wyandot, like many of their neighbors, cast their lot with the British. The Delaware, true to their traditional role as "peacekeepers" between nations, sought to remain neutral in the conflict. The Wyandot recognized the Delaware's respected position in the Ohio Valley, but eyed the plain clothed German pacifists who had recently entered the Muskingum Valley with suspicion. Glikhicken's words conveyed the strong ties of kinship that the German Moravians had established with the Delaware, however, and after a moment of consideration the Wyandot leader Half King acquiesced to Glikhicken's request. Nonetheless, his reply held a subtle warning to the Moravians: "Hold your worship services and do not get involved in other affairs. You see that we are going to war now, but you should remain completely quiet and calm and do not think much about it."292

\footnotetext{
${ }^{291}$ David Zeisberger, The Moravian Mission Diaries of David Zeisberger, 1772-1781, ed. Herman Wellenreuther \& Carola Wessel, trans. Julie Tomberlin Weber (University Park: The Pennsylvania State University Press, 2005$), 396$. ${ }^{292}$ Ibid., 397. According to Delaware tradition, the Delaware accepted the status of "peacekeepers" in 1677. In doing so, they came to be known as "grandfathers" and "women" - metaphors that hinted at the Delaware's respected status among Indian peoples and their role in mediating conflict. This version of events was later challenged by Iroquois interpretations that held the Delaware were a conquered people and the label "women" was one of derision. Nonetheless, the Delaware acted of their own accord, meeting and negotiating with colonial governments with no
} 
Moravian missionaries moved to the Ohio Country in 1771 at the invitation of the Delaware Grand Council. Their arrival coincided with a period of upheaval in both Delaware and Moravian communities and signaled a continuation of the Delaware-Moravian alliance that originated in the 1740s. What began as an alliance between the Brethren and Indians seeking access to new spiritual power gained political and diplomatic significance during and after the Seven Years' War. Delaware leaders invited the missionaries with a specific agenda: to reunite the eastern Delaware with their western kin and to use the Moravians' political connections to help in their quest to secure a Delaware homeland. Unlike the lands surrounding Bethlehem, the Ohio Country was still Indian Country and Delaware leaders - many of whom had strong nativist leanings - believed that the Moravians' spiritual influence could be contained to the mission towns. What they failed to foresee was that some prominent leaders - such as Isaac Glikhicken, Welapachtschiechen, and Gelelemind - would be drawn to the Moravians and seek to integrate more closely into the mission towns.

Four years after the Moravians first arrived in the Ohio Country, the Delaware formally adopted the missionaries and granted them "official status within the Delaware Nation." In doing so, they drew the Moravians into a complicated network of extended kin and allies that the Delaware had knit as a means to garner status and secure themselves in the region. The missionaries were not the first "white" members of the Delaware. Former white captives, seized during the Seven Years' War and adopted by Indians, created bonds between Native peoples and, at times, between Indians and colonists. The few former captives who sought to join the mission towns received a lukewarm reception from the Moravians. The missionaries' reluctance to accept

Iroquois oversight. Although factions of the Delaware fought in both the Seven Years' War and the American Revolution, Delaware leaders were instrumental as "peacekeepers" in the Ohio Valley. For a more detailed discussion of the Delaware's traditional role as "peacekeepers," see Daniel K. Richter and James H. Merrell, Beyond the Covenant Chain: The Iroquois and Their Neighbors in Indian North America, 1600-1800 (University Park: The Pennsylvania State University Press, 1987). 
"white Indians" into their communities provides valuable insight into their understanding of racial lines in the Ohio mission field, just as the Delaware's willingness to adopt white colonists hints at their racial beliefs.

In the decade between Pontiac's War and the American Revolution, Delaware peoples worked to unify their people and solidify their identity and political standing in the Ohio Country. The Delaware forged alliances and mediated peace as a means of garnering power and respect, but the American Revolution proved the limits of this strategy as the Delaware were torn between conflicting allies and powerless to keep the war from their land. ${ }^{293}$ Delaware leaders extended the Delaware-Moravian alliance by inviting the Brethren to settled in the Ohio Country and strengthened the partnership with their decision to adopt the missionaries. But when the outbreak of the Revolutionary War forced Native peoples to choose sides in the conflict, Delaware leaders found themselves facing an impossible situation where they could not uphold conflicting alliances. Some remained committed to the Delaware-Moravian partnership, even as their decision fractured the delicate political unity Delaware leaders had so recently achieved. While the Brethren remained committed to the intercultural partnership, their attempts to protect their Native friends and kin ultimately placed the mission communities in the center of the conflict. Just as the Delaware and the Moravians had been pulled inexorably into the Seven Years' War, the American Revolution unleashed forces that proved impossible to resist.

The historical record detailing the Moravians' journey to the Ohio Country, unsurprisingly, is the story of Delaware and Moravian men. But women - both Native and EuroAmerican - played a significant role in the mission towns and were instrumental in building relationships between the Brethren and Indian peoples. The Moravians had generated outrage

\footnotetext{
${ }^{293}$ Amy C. Schutt, Peoples of the River Valleys: The Odyssey of the Delaware Indians (Philadelphia: University of Pennsylvania Press, 2007), 174.
} 
from many other Protestant denominations when it became widely known that they appointed women to church governing boards and routinely ordained women as Acolytes, Eldresses, Deaconesses, and Pristerinnen (female ministers), positions that allowed women to lead absolution and footwashing ceremonies as well as ordain and deliver sermons to other women. ${ }^{294}$ By the end of the Seven Years' War, the leadership of the Moravian church had ended the choir system in Bethlehem to establish single-family dwellings and ceased the ordination of Pristerinnen. Although women continued to serve as Deaconesses and Acolytes, Eldresses were no longer allowed to ordain other women into these positions independently. As a result, the number of Deaconesses and Acolytes dwindled; the last Deaconess was ordained in 1786 and the final Acolyte four years later. ${ }^{295}$

The Ohio congregations allowed women many of the same leadership roles they had enjoyed in the early years of the Moravian missions. This was undoubtedly due in part to the fact that Moravians who traveled to the region to establish new mission towns were experienced missionaries who had been trained prior to the extensive changes in the church and who spent considerable periods of time in the field, away from the internal politics of Bethlehem. As was typical, most of the missionaries in the Ohio Valley were married couples. Zeisberger was the notable exception - he remained unmarried until 1781 despite repeated requests from the

\footnotetext{
${ }^{294}$ Beverly Prior Smaby, "Female Piety Among Eighteenth Century Moravians," Pennsylvania History 64 (1997): 151-157. Notably, women were not allowed to deliver sermons to groups that included men; women could administer but not consecrate the Communion. Women's influence in the Moravian church reached its apex between the 1750s and 1760s. After Zinzendorf's death in 1760, women's influence in the church steadily declined. Regarding lovefeasts and footwashing, see Abraham Ritter, The History of the Moravian Church in Philadelphia from its Founding in 1742 until the Present Time (Philadelphia: Hays \& Zell, 1857).

${ }^{295}$ Smaby, "Female Piety Among Eighteenth Century Moravians," 161-3. Smaby argues that it was Zinzendorf's death in 1760 that led August Spangenberg, the leader of the Bethlehem complex, to dismantle women's authority in the church. However, Spangenberg was against the decision to end the General Economy and previously supported women's role in the church. Before her death, Spangenberg's wife Eva took his place governing Bethlehem whenever he traveled. While Zinzendorf's death may have had some impact on Spangenberg's decision, I believe that he was primarily reacting to the increasingly violent protests against the Moravians.
} 
Provincial Helpers' Conference that he take a wife. ${ }^{296}$ Anne Margarethe Jungmann, the wife of missionary Johann Jungmann, worked alongside Zeisberger in Gnadenhütten and Schoenbrunn. Jungmann had been an active member in the North American missions for years. ${ }^{297}$ She was an ordained deaconess who spoke Mahican and Delaware as well as German, and through Zeisberger's diaries it is apparent that she was integral to the success of the early Ohio mission towns. Although Zeisberger offers frustratingly few details about the Moravian women who worked in the missions, Jungmann appears periodically traveling between towns to lead services and administer communion to other women. Often, she was accompanied on her journeys by "some Indian Brothers and Sisters." 298 On at least one occasion, the deaconess absolved the sins of one Indian by laying hands on her, demonstrating that ordained women continued to function as religious leaders in the western missions. ${ }^{299}$ In 1775 , Jungmann accepted responsibility to oversee the "special care of the girls." 300 Jungmann was joined in her efforts by other German women and "Indian Helpers." Sisters Johanna Schmick, Maria Roth, and Anna Sensemann also traversed the countryside, ministering to Native women and maintaining lines of communication between the mission towns.

While Delaware men were instrumental in drawing the Moravians to the Ohio Country and dominate the surviving historical records, the mission towns were filled with Native women who nurtured personal ties within the missionary communities. Jane Merritt has detailed the ways in which Indian women "created kinship networks that crossed ethnic and racial boundaries" in the early eastern missions and forced missionaries to "conform to Indian social

\footnotetext{
${ }^{296}$ Shortly after his sixtieth birthday, Zeisberger finally agreed to marry a woman that the Unity Elders' Conference recommended to him. Susanna Lecrom, who was twenty-three years younger than Zeisberger, was ordained a deaconess before traveling with Zeisberger to the Ohio region in 1781.

${ }^{297}$ Zeisberger, Moravian Mission Diaries, 64.

${ }^{298}$ Ibid., 149.

${ }^{299}$ Ibid., 295.

${ }^{300}$ Ibid., 64.
} 
and economic customs as much as Indians were expected to adapt to theirs." ${ }^{301}$ Although the mission towns represented a cross section of Native society, widows and pregnant women were particularly drawn to the Moravians, likely because alcohol was banned and food shortages rare. ${ }^{302}$ The Ohio missions did not adopt the choir system for living purposes, but worshipers divided along gender and age lines for special services. Moravian women ministered to Indian women, met with individuals and in small groups to discuss spiritual matters, and administered communion. Independent from their male peers, Moravian and Native women formed connections and support networks in ways that combined traditions from both groups.

These communities of women often came to function as extended kin networks. Native women, accustomed to community support in raising children, depended on their peers to help look after children and in at least one instance, an Indian woman asked her Moravian friend to adopt a child she felt unable to adequately provide for. ${ }^{303}$ Native women asked German women to attend them in childbirth, where the Moravians offered assistance as well as prayers for the mother and child. In turn, Moravian women relied on Indian healers within the mission community. John Heckewelder noted that "the wives of Missionaries, in every instance in which they had to apply to the female physicians, for the cure of complaints peculiar to their sex, experienced good results from their abilities." ${ }^{304}$ Moravian and Indian women also worked together to resolve domestic issues in ways that adhered to norms in both communities.

\footnotetext{
${ }^{301}$ Merritt, At the Crossroads, 55, 70. Merritt examines the missions in central Pennsylvania.

302 Zeisberger, The Moravian Mission Diaries, 69; Jane Merritt, At the Crossroads: Indians and Empires on a MidAtlantic Frontier, 1700-1763. (Chapel Hill: University of North Carolina Press, 2003), 64-6; Gunlog Maria Fur, A Nation of Women: Gender and Colonial Encounters Among the Delaware Indians. (Philadelphia: University of Pennsylvania Press, 2009), 141. All of these authors note that alcohol abuse was a significant social problem in the Ohio Country, as it was in many other regions. Merritt points out that some women who engaged in trade at times profited handsomely from the sale of liquor. Although women also consumed alcohol, they frequently became victims of alcohol-fueled violence. Many women sought protection for themselves and their children in the Moravian communities.

303 Jane Merritt, At the Crossroads, 144-45.

${ }^{304}$ John Heckewelder, History, Manners, and Customs of the Indian Nations who once Inhabited Pennsylvania and the Neighboring States (Philadelphia: Publication Fund of the Historical Society of Pennsylvania, 1881), 229.
} 
Marriages in Delaware and Mahican society were rarely permanent, meaning household conflict could be ended when one partner chose to leave. Moravian leaders expected their converts to maintain lifelong monogamous unions, however, which fundamentally changed the dynamics of marriage and women's ability to control their households. In situations where a husband was abusive or failing to adequately support his family, Moravian women welcomed Indian women into their homes, albeit usually on a temporary basis as the couple worked toward resolution.

Beyond offering support to one another in the common tasks and trials of daily life, Moravian and Native women also connected in the spiritual realm. Some Delaware women served as eldresses, a role that enabled them to act as lay ministers in the community. ${ }^{305}$ Women gathered to take communion and engage in the Moravian "lovefeasts" and footwashing ceremonies together. ${ }^{306}$ The communities of women that evolved in the mission towns fostered close personal ties that contributed to the success of the missions and connected mission towns to the broader Native community. ${ }^{307}$

Similarities notwithstanding, the Ohio missions remained distinct from their eastern predecessors. The Ohio missions modeled their towns after local Indian villages. The Indian converts organized their homes and divided their labor according to Native customs, although the Moravians modeled traditional Euro-American gender norms in hopes that the Indians would follow. ${ }^{308}$ Further removed from white settlements than Bethlehem had been, the missionaries were more reliant on their Indian brethren for information and news from the outside world. Perhaps the most significant difference between the earlier eastern missions and those in Ohio

\footnotetext{
305 Merritt, At the Crossroads, 104.

306 Amy Schutt, "Female Relationships and Intercultural Bonds in Moravian Indian Missions," in Friends and Enemies in Penn's Woods: Indians, Colonists, and the Racial Construction of Pennsylvania, ed. William A. Pencak and Daniel Richter (University Park: The Pennsylvania State University Press, 2004), 90.

${ }^{307}$ Merritt, At the Crossroads, 102.

${ }^{308}$ Ibid., 67, 115, 129, 256-57.
} 
was that while only Moravians and Indian converts called the eastern missions home, the Ohio mission towns became home to a third group - white captives.

Throughout the Seven Years' War, Indian warriors seized hundreds of white settlers in raids that littered the landscape with burned homesteads and bodies and cleared swaths of the Pennsylvania countryside of white inhabitants. ${ }^{309}$ Captive women and children were far more likely than adult men to be adopted into Indian families, where many of them assimilated and became fully accepted as members of the tribe. Male captives were often sold to the French as prisoners of war - destined to be exchanged back to the British - or executed. ${ }^{310}$ By nearly all accounts, Native Americans succeeded admirably in converting white captives to Indian ways of life, especially if the captives were young. ${ }^{311} \mathrm{With}$ the end of the war, the position of these whites in Native communities grew uncertain. British colonial governments demanded that all white prisoners be returned, and many were, returning east where they reentered colonial society with varying degrees of success. But many others chose to remain with their Native families - in some cases, the only family they had ever known.

The presence of white Indians in the Ohio Valley posed a dilemma for the Moravians. When the Moravians shifted their missionary efforts to the Ohio Country in the 1770s, they did so convinced that the success of their missions would depend on their ability to shield the

\footnotetext{
${ }^{309}$ The Moravian missions in eastern Pennsylvania were not immune from these attacks. In November 1755, an attack on Gnadenhütten left seven men, three women, and one child dead. Warriors butchered all of the cattle and horses, and burned the bodies along with every structure in town. This town of Gnadenhütten was the first Moravian mission town by that name, located along the Lehigh River in eastern Pennsylvania. A report of this attack appeared in "Philadelphia, December 4," The Pennsylvania Gazette, December 4, 1755.

310 James Axtell, Natives and Newcomers: The Cultural Origins of North America (University Park: The Pennsylvania State University Press, 2001), 192. Axtell suggests that Indians were careful in selecting their captives and generally chose adult women or children of either sex, who were most likely to successfully assimilate. Because English captives who "became Indian" did not possess any inherent traits that made them more likely to assimilate, Axtell credits the Indians' "educational process" of assimilation. Axtell maintained that this exposure to superior Indian technology served as a beginning point for captives' conversion to Indian life. He concluded that the features of Indian culture itself, with its strong sense of community, integrity, social equality, mobility, and adventure, rather than any trait of the captives, convinced them to stay.

${ }^{311}$ Ibid., 193-97.
} 
Natives from the negative influences of white society. ${ }^{312}$ Their statutes thus dictated that only missionaries and Indians could live in the mission towns. ${ }^{313}$ Initially, white captives who sought to join the Moravian congregations were turned away. Eventually, however, the Moravians bent their rules and allowed some of these former captives to reside in the mission towns. Although the number of former white captives that appear in the Moravian records between 1772 and 1782 is small, these acculturated women used their connections to Native leaders and extensive kin networks to facilitate broader Native and white relationships and protect their Moravian friends. In 1773, less than a year after Schoenbrunn was established, John Heckewelder visited a Shawnee town along the Muskingum River. There, he "visited a white man who lives here with a white wife" and reported "she had been a prisoner and can speak nothing but Shawano." 314 Within months of Heckewelder's visit, the Baptist minister David Jones stopped at the same Shawnee town. He reported meeting Mr. Conner, "a white man from Maryland" who ran a "sort of a tavern" and offered "moderate accommodations" to travelers. According to Jones, Conner, who was a former captive himself, was well regarded in the town and he and "the chief Indian of

\footnotetext{
${ }^{312}$ Peter Silver has suggested the bloody warfare that swept through Pennsylvania during the Seven' Years' War was a catalyst for transforming the polyglot inhabitants of the borderlands into "white Folks" who united to fight against Indians - regardless of the Natives' tribal or religious affiliation. Pacifist groups such as the Moravians, Quakers, and other German peace churches in Pennsylvania were excluded from the new "white" identity not only because they refused to participate in armed attacks against Native people, but because they rejected the idea that all Indians were "enemies." Patrick Griffin's work has also pinpointed the emergence of racial identity and racial hatred to the latter half of the eighteenth century. Nonetheless, Moravian and Native understandings of race appear more nuanced. Both Zeisberger and Heckewelder routinely apply the label "white" to non-Moravian Euro-Americans, regardless of their ethnicity or circumstances, while often (albeit not always) exempting themselves from this group. Even acculturated captives, who were as or more familiar with Native life than the Moravians, were "white." This suggests that while the Germans did not necessarily consider themselves white, they did see race as a permanent trait that remained even if captives adopted the language, customs, and beliefs of their Native captors. For their part, Indians who were familiar with or sympathetic to the Moravians often differentiated between the pacifist Moravians and "whites," while Natives who were hostile to missionary efforts in the Ohio region appear less willing to make this distinction. See Peter Silver, Our Savage Neighbors: How Indian War Transformed Early America (New York: W.W. Norton and Company, 2008); Patrick Griffin, American Leviathan: Empire, Nation, and Revolutionary Frontier (New York: Hill and Wang, 2007); Nancy Shoemaker, "How Indians Got to be Red," The American Historical Review 102 (1997): 623-44.

${ }^{313}$ David Zeisberger, Diary of David Zeisberger, A Moravian Missionary Among the Indians of Ohio: 1781-1798. Vol. 1, ed. and trans. Eugene Bliss (Cincinnati: Robert Clarke \& Co., 1885), xxviii.

${ }^{314}$ John Heckewelder, Thirty Thousand Miles with John Heckewelder, ed. Paul A. W. Wallace (Pittsburgh: University of Pittsburgh Press, 1958), 111.
} 
this town are married to two sisters." Jones marveled that the adopted women "had the very actions of Indians" and concluded that they had been captives, "likely from childhood." 315 Two years after David Jones recorded his meeting with Richard Conner, Zeisberger wrote that "a White man and his wife came from Pittsburgh...they were traveling back there [to the Shawnee town] to get their child whom she had had to leave there."316 Subsequent entries in Zeisberger's diary over the following weeks and months gradually reveal Richard and Peggy Conner's story and demonstrate how adopted captives occupied the space between Native and white worlds.

Between Jones' departure from the Shawnee village in 1773 and Zeisberger's diary entry in February 1775, simmering tensions between the Ohio Country Indians and Virginians erupted into Lord Dunmore's War. From early spring until the autumn of 1774, scattered violence plagued the region, eventually culminating in the Battle of Point Pleasant, where the vastly outnumbered Shawnee were forced to retreat. The Moravians watched the unfolding events nervously. Two of the missionaries, John and Maria Roth, gathered their newborn son and retreated east to Pittsburgh. ${ }^{317}$ On October 30, 1774, Zeisberger wrote with some relief "we received news that the Gouverneur of Virginia had set up his camp with his army on the Plaine near the Lower Shawnee Towns, that the Shawnee are engaging in negotiations with him." 318 By the time that Zeisberger was writing in his journal, the Treaty of Camp Charlotte had formally ended Dunmore's War.

The ending of Dunmore's War had profound consequences for Peggy Conner. Under the Treaty of Camp Charlotte, the Shawnee not only lost their land south of the Ohio, but were

\footnotetext{
315 David Jones, A Journal of Two Visits Made to Some Nations of Indians on the West Side of the River Ohio, in the Years 1772 and 1773 (Burlington: Printed and Sold by Isaac Collins, 1774), 66.

316 Zeisberger, Moravian Mission Diaries, 271. The Conners arrived in Lichtenau from Pittsburgh on February 24, 1775.

${ }^{317}$ Ibid., 197-200. From Pittsburgh, the couple returned to Bethlehem.

318 Ibid., 234.
} 
required to deliver all of the white captives in their midst. ${ }^{319}$ While Peggy had been raised as a Shawnee, "had the exact gestures of Indians," and spoke only "broken English," she was taken to Pittsburgh under the terms of the treaty and forced to leave her young son behind. ${ }^{320}$ Richard followed his wife to Pittsburgh, where they stayed for several weeks, waiting for the worst of the winter storms to pass before heading west to retrieve their son. The couple arrived in Schoenbrunn during the last days of February. After hearing their situation, the Moravians agreed to make a temporary exception to their statutes and allowed Peggy, who was pregnant with the couples' second child, to remain in the town while Richard continued on to the "Shawnee Towns to see if he could retrieve his child." 321

The conclusion of Dunmore's War held significant consequences for the Moravians as well. At Camp Charlotte, Virginia governor Lord Dunmore met with Delaware war captain White Eyes. According to the hazy details in Zeisberger's diary, Dunmore agreed to assist White Eyes in his plan to travel to England and "straighten out the matter of the Delaware's land with the King, so that...the White people would never drive them out." ${ }^{322}$ It is possible that Dunmore suggested that the King would expect the Delaware to adopt a degree of "civilization" before granting them permanent rights to their land. In any case, when White Eyes returned from Camp Charlotte, he pushed the Delaware to grant the missionaries official status within the nation. In February 1775, the Delaware adopted the Moravian missionaries in their midst, granting them "official status within the Delaware Nation," and ensuring that "the converted Indians together

\footnotetext{
${ }^{319}$ Colin Calloway, "We Have Always been the Frontier: the American Revolution in Shawnee Country." American Indian Quarterly, 16, No. 1 (Winter 1992): 39-52.

${ }^{320}$ Jones, A Journal of Two Visits, 65. There is no mention in the records of why Peggy could not take her child to Pittsburgh with her. Presumably, Peggy's Shawnee family considered the child their kin and because he was born in the village did not fall under the dictates of the Camp Charlotte Treaty.

${ }^{321}$ Zeisberger, Moravian Mission Diaries, 270.

${ }^{322}$ Ibid., 250.
} 
with their teachers would enjoy all the rights, liberties and properties pertaining to

Delawares." 323

This declaration secured the Moravians' status in the Ohio Valley and transformed the informal support networks between the missionaries and Indians into legitimate kinship ties. Whether literal or symbolic, kinship forged chains of obligation between individuals and groups, and cemented economic, political, and military alliances between peoples. Offering gifts, engaging in trade, and exchanging information nurtured relationships and ensured that alliances remained secure. ${ }^{324}$ In regions such as the Ohio Valley, where fragments of various tribes, villages, and clans gathered and formed new aggregate communities, people often found themselves in the midst of complicated kinship networks. Since migrating to the Ohio region, the Delaware had worked diligently to acquire alliances among many groups. Zeisberger noted that "the Delaware have powerful connections, being in league with most of the nations" and were the "grandfather to all these nations." 325 Although widespread alliances offered security and power, they also held the potential to become liabilities when circumstances forced Indians to choose between competing loyalties and obligations. ${ }^{326}$

Adopting the Moravians was a politically savvy move in more ways than one. For Netawatwees and other Delaware leaders, this was a calculated step toward garnering colonial support as they maneuvered to gain a legal title to their land. Not only could formal kinship ties between the Delaware and the missionaries promote the Delaware's cause to the British monarch, but the bond helped solidify the reputation of the Delaware as a "people with a

\footnotetext{
${ }^{323}$ Ibid., 148.

${ }^{324}$ Schutt, Peoples of the River Valleys, 51-59.

${ }^{325}$ David Zeisberger, David Zeisberger's History of the Northern American Indians, eds. Archer Butler Hubert and William Nathaniel Schwarze (Columbus: Press of F.J. Heer, 1910), 109-10.

${ }^{326}$ Richard White, The Middle Ground: Indians, Empires, and Republics in the Great Lakes Region, 1650-1815 (New York: Cambridge University Press, 1991), 18-22.
} 
particular peacemaking mission." ${ }^{327}$ An association with the Moravians, well known for their abhorrence of violence and warfare, facilitated the Delaware's agenda of neutrality and peace and allowed them to maintain their tenuous position as mediators of intertribal alliances in the early years of the American Revolution.

While their new status entitled the missionaries to the protection of Delaware warriors, as part of the Delaware family and kin network, the mission congregation was expected to "contribute its share to the costs of the diplomatic and other activities of the Delaware." 328 The most significant aspect of these new obligations was the expectation that the Moravians provide the trade goods and gifts that fostered friendships and alliances between the Delaware and the other Indian peoples of the Ohio region. The Moravians' agricultural pursuits, combined with the provisions that they stocked in the mission towns, transformed these towns into "important regional economic centers." 329 Becoming adopted members of the Delaware had broad implications that the Moravians may not have fully grasped. In accepting their new kinship position, the Moravians inextricably tied their future in the Ohio Valley to that of the Delaware. As the colonies edged toward war with Great Britain, and the Ohio Indians were once again forced to choose sides in an imperial war, the Moravians were deeply vested in maintaining Delaware neutrality, even if doing so required them to break their vow to avoid engaging in political matters.

Two months after Richard Conner left Schoenbrunn he returned empty handed, although he assured Peggy "the Chiefs promised him that he would get his child back." ${ }^{330}$ Fresh from his unsuccessful campaign to retrieve his child from the Shawnee, Conner embarked on a new quest

\footnotetext{
327 Schutt, Peoples of the River Valleys, 141.

${ }^{328}$ Herman Wellenreuther and Carola Wessel, introduction to Zeisberger, Moravian Mission Diaries, 68.

${ }^{329}$ Ibid., 69.

${ }^{330}$ Zeisberger, Moravian Mission Diaries, 270.
} 
to convince the Moravians to allow him and Peggy to remain living in Schoenbrunn and become permanent members of the community. In the spring of 1775 , the missionaries were the only Euro-American residents of the mission towns, and Zeisberger and the other Moravian leaders were reluctant to change that dynamic. Conner, however, was not easily dissuaded. He argued that "his wife has gotten very used to us while she has been here," and Zeisberger conceded that Peggy "is so obliging toward the Sisters...that we could see it would be difficult for her to leave here.” Indeed, Peggy had been eager to settle with the Moravians for quite some time. According to Richard, "his wife had already asked him numerous times to go to our [the Moravians] place, several years ago when they still lived among the Shawnee." Conner reminded Zeisberger that when he had stayed at Conner's tavern during a journey to the Shawnee in 1773, the two had talked "half a night about being saved and what is required for this." The couple's brief stay in Pittsburgh had convinced Peggy that she could not "fit in with White people, especially people like those at the Fort," but yet did not "want to live among the savage Indians any more."331 Schoenbrunn, with its blend of Native and Euro-American residents and culture, seemed one of the few places for the Conner family.

The Reverend David Jones had privately thought Richard Conner "a man that seems not to fear God and it is likely he will not regard man," but Conner worked to convince the Moravians that he not only feared God but was willing to regard all of the Moravians' rules. Several weeks after Conner returned to Schoenbrunn, Zeisberger noted with a touch of exasperation that "we have explained everything to him and made enough objections, but he refuses to be deterred by this." 332 Eventually, after considering "Mr. Conner's situation...many times," the Moravians capitulated and agreed to "make a trial" of the Conners' residence after

\footnotetext{
${ }^{331}$ Ibid, 270.

332 Jones, A Journal of Two Visits, 66; Zeisberger, Moravian Mission Diaries, 271.
} 
discussing the matter "from all sides with the Indian Brothers and Sisters." 333 The Conners vowed to "submit to our rules just as the Indians who come to us must do" and took their place alongside the non-baptized Indians. ${ }^{334}$

The missionaries' reluctance to welcome William and Peggy Conner to their mission town provides insight into how the Moravians parsed racial lines in the Ohio mission field and categorized those around them. Even as understandings of race were in flux during the late eighteenth century, both Zeisberger and Heckewelder routinely applied the label "white" to nonMoravian Euro-Americans, regardless of their ethnicity or circumstances, while often (albeit not always) exempting themselves from this group. ${ }^{335}$ It is possible that the missionaries' main objection to accepting the Conners as permanent residents stemmed from William Conner's history as a trader. Nativist opposition to British traders - and the Christian missionaries remained strong and the Moravians could ill afford to give their opponents ammunition against them. But their subsequent treatment of other captives proves otherwise. In December 1776, only a year after the Conners came to live in Schoenbrunn, the Wyandot Half King's wife arrived in the village with two of her sons and "a White man who had been captured some time ago in Assünnünk and was given to this woman in place of her brother." The man had lived with the Delaware leader Welapachtschiechen "for some years" and was eager to rejoin him. The Moravians, however, "spoke with Welapachtschiechen and told him that we could not allow any White people to live here" and advised that he "free himself of the man who had come here from

\footnotetext{
${ }^{333}$ Richard Conner was ahead of the missionaries and had already discussed his plan with White Eyes.

334 Zeisberger, Moravian Mission Diaries, 271.

335 The Moravians diaries vary in how they refer to both Euro-Americans and Native Americans. At times the writers use the phrase Weißen leute (white people) to describe American colonists, but at other times they also simply use Leute (people). The diaries refer to Native peoples as Indianer (Indian), but occasionally will simply use Leute. For an example, see Moravian Indian Diary, Philadelphia Barracks, Bethlehem Digital History Project, http://bdhp.moravian.edu/community_records/christianindians/diaires/barracks/1764/1764janthrufeb.pdf.
} 
the Wyandot." ${ }^{336}$ A decade later, John Leeth, a former captive who had been adopted by the Delaware as a teenager, claimed he "could not remain away" from the Moravians and "was resolved to live" in the mission town. ${ }^{337}$ Leeth's wife was "also a prisoner to the Indians; who had been taken by them when about twenty months old." 338 Zeisberger noted that the couple "asked very earnestly to be received" and while the missionaries "pitied him" it "was a well fixed rule with us in all our missions to receive no white people," so they could not allow Leeth and his wife to remain "before we had inquired of the brethren in Bethlehem about it."339 Thus, even acculturated captives, who spoke Native languages as their primary tongue and maintained close kinship ties with Native peoples, were "white." This suggests that while the missionaries did not necessarily consider themselves as belonging to Pennsylvania's "white people," they did see race as a permanent trait that remained even as captives adopted the language, customs, and beliefs of their Native kin.

If the Moravians were inconsistent in how they defined their racial identity, so too were Ohio's Native peoples. Indians who were familiar with or sympathetic to the Moravians often differentiated between the pacifist Moravians and "whites," while Natives who were hostile to missionary efforts in the Ohio region appear less willing to make this distinction. Even as Netawatwees invited the missionaries to the region, his son John Killbuck remained wary. Killbuck strongly objected to the decision to invite the pietists to Indian country. Zeisberger believed that Killbuck had "secretly incited the people against us" at Gekelemukpechünk and

\footnotetext{
336 Zeisberger, Moravian Mission Diaries, 350.

337 Zeisberger, Diary of David Zeisberger, 299.

338 John Leeth, A Short Biography of John Leith, with a Brief Account of His Life Among the Indians (Cincinnati: Robert Clark \& Co., 1883), 41.

${ }^{339}$ Zeisberger, Diary of David Zeisberger, 299. This was after the missionaries made exceptions for Richard and Peggy Conner; Zeisberger writes that "we had examples that we had fared badly with such people, and had afterwards much repented of having received them."
} 
"made up all sorts of evil accusations against us." 340 While his father Netawatwees and his son Gelelemind worked alongside the Moravians, Killbuck declared his desire to "kill the white people, i.e. us Brethren and Sisters in Schoenbrunn and Gnadenhütten." ${ }^{341}$ Yet it appears that other Indians who shared Killbuck's inclination to "kill the white people" did not consistently include the Moravians in this definition. In the early morning hours of November 12, 1776, missionary John Heckewelder "got up at daybreak and opened the doors" to find six Minque warriors "standing directly across" from his house. They informed the Indian brothers "we are looking for White people so we can beat in their heads." The brothers "told them there were no White people here" and asked why they were seeking "White people in the Delaware Towns?" When the warriors replied "We know some are here and we want to see them," the Indian brothers hastened to assure them that the only white people present were "their teachers, and they were their friends." The warriors replied "We know they [the Moravian missionaries] are there and if we had wanted to kill them, we would have done so before you knew anything about it. We do not want to do anything to them; we are looking for Traders." 342

This exchange demonstrates the Moravians' ambiguous racial standing. When the warriors demand to see the "White people," the Indian brothers first replied that there are "no White people here." Given the setting of this exchange - right outside of Heckewelder's house, in the middle of a mission town - this claim seems disingenuous if the Moravians were widely understood to fall into the category of "white." But when pressed, the Indian Brothers clarified that the only "White people" in the town were the missionaries, only to have the warriors dismiss this information and specify that it was "Traders" they sought. The Brothers correctly assumed

\footnotetext{
${ }^{340}$ Zeisberger, 135.

${ }^{341}$ Gnadenhütten Diary, April 7, 1774, trans. Schwarze, Moravian Archives, Bethlehem, PA, quoted in Scott Paul Gordon, "The Killbuck-Henry Legend Revisited, Part 2: Gelelemend," The Jacobsburg Record 37 no. 3 (April 2010): 4.

${ }^{342}$ Zeisberger, Moravian Mission Diaries, 341.
} 
that the Moravians were not the "White people" that the warriors hoped to find, but clearly there was some degree of uncertainty at play. ${ }^{343}$ While the Moravians considered former captives like Peggy Conner "white" and thus outside the defined boundaries of the mission towns, both the missionaries and adopted captives occupied a liminal space between Native and white society. In November 1775, Richard left Peggy and his newborn son to again travel to the Shawnee Towns on the Muskingum in hopes of retrieving his firstborn child. This time, however, he had company. John Gibson, newly appointed Agent of Indian Affairs by the Continental Congress, had stopped overnight at Schoenbrunn on his way to "receive the prisoners...promised them in the Treaty" from the Shawnee. ${ }^{344}$ Conner joined Gibson when he left Schoenbrunn the following morning, and the men disappeared for four months. On March 18, Zeisberger reported "Mr. Conner returned from the Shawnee," this time with his son, who "is 4 years old and cannot speak anything but Shawnee." Gibson arrived a week later, with "a party of warriors and about 20 white prisoners." Although Conner had successfully retrieved his child after "paying another 40 bucks" for him, Gibson "had much work and trouble and had endured many dangers until he got a party of warriors on his side." The warriors were necessary because after weeks of negotiations, it had become clear to Gibson that the Shawnee were not about to give up their "white prisoners" and the "prisoners" themselves had little interest in accompanying him to Pittsburgh. Backed by a party of warriors, he "took the prisoners away by force" and declared "if they could not take them to the Fort alive, they would take their Scalps there." 345 Despite this inauspicious beginning, Zeisberger noted that many of the former captives attended the Moravian's services and "were all very grateful and apprecitive [sic] of the good

\footnotetext{
${ }^{343}$ In May 1777, Zeisberger noted that the Indians had adopted the term "Virginians" to refer to "all White people." Zeisberger, Moravian Mission Diaries, 377.

${ }^{344}$ Ibid., 290. Gibson is referring to the Treaty of Camp Charlotte, signed a year prior.

${ }^{345}$ Ibid., 307-8.
} 
hospitality they had enjoyed here." ${ }^{346}$ Months later, "7 White people passed through here going to the Shawnee...to visit their friends there." Although Zeisberger neglected to mention if any of these visitors had stayed with the Moravians previously, "five of them had been prisoners" among the Shawnee. ${ }^{347}$

As the reunited Conner family settled into Schoenbrunn, the Moravians greeted Welapachtschiechen, a "headman among the Indians" and leader of the Delaware Turkey Clan. Welapachtschiechen listened attentively to the missionaries as they discussed their teachings and then shared his hope that another "Town would be established for Indian Believers" close to his village of Assünnünk. ${ }^{348}$ Welapachtschiechen maintained that he and "the Indians who lived with him, currently about 10 families," were eager to "accept God's word." ${ }^{349}$ While it is hard to say with certainty whether this was the case, there was without doubt one member of the village advocating for the Moravians. Rachel, Welapachtschiechen's wife, was a white woman who had been taken captive from Virginia during the Seven Years' War and adopted into the Delaware tribe. According to Zeisberger's diary, Rachel pressured her husband to move to Schoenbrunn so that their three children might grow up among the Moravians.

Welapachtschiechen's request for an additional mission town close to his own village may have reflected his desire to balance his wife's wish to live with the Moravians and his own responsibilities as a Delaware leader. But in the spring of 1776, the Moravian missionaries were stretched thin. As the Ohio Country teetered on the edge of yet another war, the Moravians found their Indian missions threatened once again. Given the Delaware's primary goal to secure a land title, they did not want to risk aligning themselves with the losing side in a British-American

\footnotetext{
346 Ibid., 307.

${ }^{347}$ Ibid., 330.

${ }^{348}$ Ibid., 297-98.

349 Ibid., 314.
} 
conflict. The Moravians, with their pacifist views, supported Delaware neutrality. However, as the Revolution progressed, neutrality became less of a possibility with each passing day. Rather than being respected as neutral "peacemakers," the Delaware and the Moravians were viewed with suspicion by all sides. The active fighting in the early stages of the Revolutionary War damped the Moravian's missionary efforts and they responded to the Delaware's "Invitation to come to Assünnünk by sending word that we would wait and see how things went because currently we are hearing only bad news." 350

Unfortunately, the news grew only worse. During the autumn of 1776, the Ohio Valley simmered with barely contained violence. The missionaries' reports to Bethlehem were filled with worrisome reports that "another Company of Wyandot had gone to war," and "over 100 Wyandot, Tawa, and others had gathered in Detroit and they would march to Virginia on an expedition any day now." ${ }^{351}$ Even more troubling were the unavoidable signs of violence. On October 23, Zeisberger wrote that a party of Wyandot and Minque had murdered eleven settlers, a report that was echoed in the Pennsylvania Gazette a few days later, although the Gazette held the Tawas (Ottawas) and "other disaffected Indians" responsible as well. ${ }^{352}$ Days later, Zeisberger ominously noted that "a party of Wyandot had returned with 3 scalps." ${ }^{353}$ Faced with the prospect of open warfare spreading to the Muskingum Valley, the Moravians abandoned their scruples and openly cultivated political allies among the Delaware's increasingly fractionalized leaders. When Welapachtschiechen expressed his desire to resign his leadership position among the Delaware and move to Schoenbrunn to live with the Moravians, Zeisberger persuaded the chief to remain in his position of power. Given the political climate, Moravian leaders

\footnotetext{
${ }^{350}$ Ibid., 330.

${ }^{351}$ Ibid., 338-39.

352 “Williamsburg, October 26," Pennsylvania Gazette, November 6, 1776.

${ }^{353}$ Wellenreuther and Wessel, introduction to Zeisberger, Moravian Mission Diaries, 340.
} 
recognized that they could not risk losing leaders who were dedicated to maintaining Delaware neutrality and held strong political sway over their clans. ${ }^{354}$ Despite their circumstances, the missionaries continued to require their Indian converts to refrain from "concerning themselves with political matters or warlike efforts" - an impossible task that the missionaries themselves could no longer pretend to uphold. ${ }^{355}$

The Delaware leader Netawatwees had been instrumental in bringing the Moravians to the Ohio County and maintained close contact with the missionaries as the British colonies unraveled. His son Killbuck and grandson Gelelemind were also active political players between the Seven Years' War and the American Revolution. As a new war spread across the land, the Moravians leaned heavily on their connection with Netawatwees to secure the mission towns. ${ }^{356}$ Their relationships with Killbuck and Gelelemind proved more complicated. Killbuck had myriad reasons to oppose the Moravian's influence in the Ohio Country. Interestingly, his opposition stemmed in part from the Moravians' pacifism - one of the very traits that made the missionaries more attractive to other Delaware leaders. But their refusal to take up arms also meant that the Moravians "could not protect them in war time." ${ }^{357}$ Killbuck pointed to "the distresses and dangers of the Moravian Indians last war," claiming "that for all the assistance that the Moravians could give, their Indians might have been killed." ${ }^{358}$ He had raised this objection

\footnotetext{
${ }^{354}$ Gregory Schaaf, Wampum Belts and Peace Trees: George Morgan, Native Americans, and Revolutionary Diplomacy (Golden, CO: Fulcrum Publishing, 1990), 76.

355 Zeisberger, Moravian Mission Diaries, 59-63.

${ }^{356}$ Netawatwees was also called Newcomer by the colonists. Netawatwees' son Killbuck went by the names Captain Killbuck and Bemino/Bemineo; his grandson Gelelemind also appears in the records as Gelelemind, John Killbuck, and Killbuck Jr. For clarity, I use the name Killbuck when referring to Netawatwees' son and Gelelemind when referring to his grandson.

357 Gordon, "Killbuck-Henry," 4; Quotation from Jones, 99.

358 Jones, 98-9. Scott Gordon and others have assumed that Jones spoke with the elder Killbuck. I'm writing under this assumption as well, although the text is not entirely clear; this conversation came before Gelelemind expressed his support for the Moravians and therefore I think it is possible that Jones was speaking with the younger Killbuck. See also Zeisberger, Moravian Mission Diaries, 158, where Killbuck argues against the Moravians and claims that he is "going to see Johnson," referring to William Johnson, then superintendent of Indian Affairs, who Killbuck believed would inform the Delaware that the Moravians "would not be allowed" in the Ohio Country.
} 
before the Moravians were firmly established along the Muskingum, but with the outbreak of war his fears gained new relevance. While he had tempered his stance toward the Moravians and no longer threatened physical harm, Killbuck continued to work against Moravian interests in the region.

Unlike his father, Gelelemind supported the mission wholeheartedly and before long sought to join the community. In January 1776, he informed the missionaries of his "desire in my heart...to become a believer, to love the Saviour, and to become a saved person." Gelelemind's eagerness to join the Moravians concerned his grandfather and drew the ire of many of his peers. Netawatwees asked him to consider "What will happen to the Chief affairs and the worldly government and who will take care of this if you leave me?" 359 Gelelemind acknowledged that "my uncle, the chief, desires that I should take his place," but also claimed “...I do not wish this; I want to have the Saviour." 360 Netawatwees persuaded him not to leave Goschachgünk, suggesting "perhaps a town of the Brethren would be built near them." And indeed, in the spring of 1776, the Moravians established Lichtenau at the invitation of the Grand Council. It is difficult to know to what degree Gelelemind's wish to live with the Moravians factored into Netawatwees' decision to invite the missionaries to the area. But if the move was aimed at keeping Gelelemind in Goschachgünk, it succeeded. Gelelemind decided that he would not risk "drawing upon himself the enmity of his friends" by moving to the mission but would instead simply visit the Moravians to "hear the Word of God in the neighborhood of Goschachgünk."361 The backlash against Gelelemind's open desire to join with the Moravians highlights how controversial the missions remained in the Ohio Country. The Grand Council formally invited

\footnotetext{
359 Zeisberger, Moravian Mission Diaries, 322.

${ }^{360}$ Gnadenhütten Diary, January 3-4, 1776, trans. Schwarze, Moravian Archives, Bethlehem, PA, quoted in Scott Paul Gordon, "The Killbuck-Henry Legend Revisited, Part 2: Gelelemend," The Jacobsburg Record 37 no. 3 (April 2010): 4.

${ }^{361}$ Ibid., February 16, 1776, quoted in Gordon, 4.
} 
the missionaries to minister to the Delaware in hopes of drawing the eastern mission residents to the Ohio Country; they did not necessarily wish to see the Moravians draw new converts from their ranks.

It is not surprising that Gelelemind's family and friends intervened to dissuade him from joining the mission community. The Moravians were also reluctant to accept the influential leader, however. It would seem that the Moravians would be eager to welcome a high-status individual such as Gelelemind to their community. Nonetheless, Zeisberger and the other missionaries tread carefully. It appears that Netawatwees expected Gelelemind to be his successor and the Moravians, as always, kept an eye on the larger picture rather than focusing on individual converts. Just as they had with Welapachtschiechen, the Moravians discouraged Gelelemind from seeking baptism, reminding him that all converts were required to abandon "worldly endeavors." This pattern of denying willing converts a place in the mission towns reflects similar choices that the Moravians had made during the Seven Years' War. The Moravians had initially refused to allow Timothy Horsfield and William Edmonds to join them in Bethlehem, deeming them more useful as affiliated members outside of the mission community in light of their political activities. The same logic dictated that Zeisberger and his fellow missionaries would not allow either Gelelemind or Welapachtschiechen to enter the Ohio missions.

Although Welapachtschiechen accepted that the Moravians encouraged him to retain his position on the Grand Council but also refused to allow him to reside in Schoenbrunn because of his political activities, he requested that the Moravians "call his family here so that they would be out of danger" while he and Gelelemind traveled to Fort Pitt to meet with representatives from 
the Continental Congress. ${ }^{362}$ Perhaps sensitive to their own hypocrisy, the missionaries agreed to shelter Rachel and her children as well as Gelelemind's wife and children in Lichtenau. Both Rachel and Gelelemind's wife (who remains nameless in the records) had previously expressed their desire to "become part of the congregation," but had been advised to remain with their husbands. In the initial years of the Ohio missions, the Moravians were careful to avoid disrupting familial relationships within Delaware towns and on several occasions counseled women to remain with their husbands rather than move to missions alone. ${ }^{363}$ When Rachel moved into a house in Lichtenau, she exclaimed "Oh, how happy I am to be here at last," and told the Sisters "I have often longed to come to your place and live with you...I woke up happier this morning than I can ever remember being."364

Welapachtschiechen and Gelelemind were part of a larger delegation of Delaware, Munsee, Mohican, Shawnee, and Iroquois who gathered at Fort Pitt on the morning of October 26, 1776 to meet with commissioners from the newly formed Continental Congress. The commissioners optimistically aimed to secure Indian alliances against the British, but recognized that securing promises of Native neutrality was a more achievable goal. The conference failed to produce the results the Continental Congress had hoped for, however. In the aftermath of the talks, several tribes in the Ohio Country, including the Wyandot, Shawnee, and Mingo, gravitated toward British alliances.

As the Delaware occupied an increasingly tenuous position in the Ohio Country, they lost the one leader who may have been capable of maintaining Delaware neutrality. After a short

\footnotetext{
362 Ibid., 336.

${ }^{363}$ Schaaf, Wampum Belts and Peace Trees, 191.

${ }^{364}$ Zeisberger, Moravian Mission Diaries, 339.
} 
illness, Netawatwees died on October 31, 1776 in Pittsburgh. ${ }^{365}$ Gelelemind replaced him as the primary chief of the Delaware, but perhaps because of his close affiliation with the Moravians, he proved unable to hold together the increasingly fractured Delaware. The changing dynamics in the Ohio Country forced the Moravians to reconsider some of their previously non-negotiable rules. The missionaries had feared they would sacrifice valuable political allies if they allowed influential men like Welapachtschiechen and Gelelemind to receive baptism and abandon their political activities. The Wolf Clan's movement toward a formal alignment with the British forced the Moravians to be pragmatic, even if at the expense of compromising their ideals. When Welapachtschiechen returned from the conference at Fort Pitt, he did not travel to Assünnünk but remained in Lichtenau with his family. Although he never relinquished his position in the Grand Council, Welapachtschiechen and Rachel were baptized several months later and accepted as permanent members of the congregation. ${ }^{366}$

As winter deepened, John Anderson, the "honest Quaker trader" who frequently carried messages from the Continental Congress to the Ohio Country, urged the Moravians to "retreat among the White people and put ourselves under their Protection," informing Zeisberger that the "Commissioners in the Fort had written to Congress about this...they would propose this to the Delaware in general and also to our Indians." Zeisberger, however, recognized that "if we had our choice, we would prefer to stay here in Indian Country despite all the wars, because we can see in advance that some harm will be done if we got to the Settlements of the White people." 367 Weeks later, Gelelemind offered his own plan for protecting those residing in the mission towns.

\footnotetext{
${ }^{365}$ Earl P. Olmstead, David Zeisberger: A Life Among the Indians (Kent, OH: Kent State University Press, 1997), 16.

366 Zeisberger, Moravian Mission Diaries, 425. Welapachtschiechen took the name Israel at his baptism.

${ }^{367}$ Ibid., 337. Wellenreuther and Wessel note that in a letter from the Commissioners for Indian Affairs dated September 25, 1776, the commissioners reported that tensions had eased and that they "had disbanded the larger part of the militia." This runs contrary to Anderson's report to the Moravians. See 337 n. 841.
} 
He warned that "it is possible that the Delaware Nation might get involved in bargains or even in a war with other Nations if large parties of warriors should come here to harm the White Brothers and the Indians fend them off." He offered that "it might be possible" to protect the Moravians and their coverts "if our Indians from Schoenbrunn and Gnadenhütten all moved here to Goschachgünk and took the White Brothers among them." ${ }^{368}$ When another missionary suggested that the Moravians retreat to Fort Pitt if they appeared to be in danger, Zeisberger shared his fear that the missions would "be scattered and perish" if they left and his determination to "take a chance on them [the warriors] killing him and on dying with them [the Christian Indians]." ${ }^{369}$ To this, Isaac Glikhicken responded that he would tell any warriors who threatened the Moravians "Before you kill our teachers, you should kill me. As long as I am alive, you will not do anything to them," and recounted how he had recently jumped up from an injury upon hearing "that there were warriors in the Town looking for White people." 370

The following day, December 7, 1776, a message arrived in Goschachgünk from Indian agent George Morgan. Morgan wrote that the Continental Congress had proposed to "build a Fort for their safety anywhere they wanted to, if they thought this necessary" and promised to defend them if other Nations should attack them or force them to wage war against the White people." ${ }^{371}$ Morgan addressed his letter to Gelelemind, but dispatched a letter to Zeisberger as well urging him to "explain to Killbuck [Gelelemind] carefully the passage about the fort."372 Zeisberger was either not privy to the ensuing debate or did not feel the need to document it in the mission diary; the Delaware did not accept the offer, however. Two decades earlier, both the Moravians and Indians had advocated for the construction of Fort Allen to protect Bethlehem

\footnotetext{
368 Ibid., 346.

${ }^{369}$ Ibid., 346.

${ }^{370}$ Ibid., 347.

${ }^{371}$ Ibid.

372 Ibid., 347 n.874.
} 
residents and Native peoples in the midst of the Seven Years War. But in 1776 the dynamics were strikingly different. A potential fort was not seen as a place to facilitate negotiations and provide refuge, but rather as a tacit alignment with the Americans - an alliance that would threaten Delaware neutrality and potentially escalate violence in the region. Furthermore, many Delaware advocated for an alliance with the British should neutrality prove an unviable option. Erecting a fort outside of Goschachgünk would establish an influential white presence in the region and undermine Native war efforts.

With the Delaware's neutrality far from assured, the Moravians realized that their adoptive kinship bonds with the Delaware no longer afforded them the protection they had once enjoyed. Because of their close ties with the Delaware people - some of whom were now openly fighting against the Americans - American officials grew increasingly convinced that the Moravians were helping the British. More immediately problematic, British-allied Natives suspected the Moravians were sympathetic to the Americans because the Grand Council refused to ally themselves with their neighbors. Kinship networks between the Moravians and Indians extended beyond the Delaware, however, and the Moravian leaders were startled to realize that they enjoyed protection from unexpected sources.

In the summer of 1777, Peggy Conner's adopted brother, a "Shawnee Captain," arrived in Lichtenau with a group of Shawnee warriors. Zeisberger eyed them warily, noting "we were somewhat concerned...they live among the Mingo and are not very well disposed toward the White people." ${ }^{373}$ Perhaps more alarming, Peggy's brother "had come through...recently with a party of warriors and had prisoners with him." 374 The Shawnee declared that he had come "to get his sister Peggy Conner...because times were so dangerous and he feared he would someday see

\footnotetext{
373 Ibid., 392.

${ }^{374}$ Ibid.
} 
his sister taken away as a prisoner, which he would not like." 375 The Brothers hastened to forestall this plan, presumably with the Conners' blessing.

After spending several days at the mission and attending religious services with the Moravians, Peggy's brother was mollified. The warrior clearly had doubts about the mission town prior to his visit. As Zeisberger diplomatically noted, the Shawnee had "heard much about us...however, since he had been here all of his concerns had left him." ${ }^{376}$ Although the Shawnee Captain's primary concern was undoubtedly for his sister, he declared the Moravians his "friends" and offered his protection, promising that he would "tell the Mingo and the warriors he saw not to harm us, because his friends lived here."

Peggy's presence in Lichtenau secured a degree of protection for the Moravian villages as a whole. Her kinship ties with the Shawnee Captain likely influenced his decision to extend the bonds of friendship to the Moravians and intervene on their behalf. As a member of both the Shawnee and the Moravian church, Peggy bridged the space between the two. Not only did Peggy's Shawnee brother work to protect the Moravians and their converts from hostile Indians, he used what limited means he had to guard the mission town from hostile whites in the region, stating he "wanted to turn away the warriors if possible so that they did not come here to our place as much." 377

The Captain's desire to keep warriors from entering Lichtenau acknowledged the Moravians' delicate position. As the Moravians and Christian Indians residing in the Ohio Valley struggled to convince others of their neutrality and pacifism, they offered food, supplies, and shelter to any party that passed through their villages, whether British or American, in an attempt

\footnotetext{
${ }^{375}$ Ibid., 393. Whether the Captain was aware of any direct threats to the Moravians is unknown. Although the records are silent about Peggy's reaction to her brother's plan, presumably she was inclined to stay in Lichtenau. ${ }^{376}$ Ibid.

${ }^{377}$ Ibid.
} 
to secure good relationships and garner support. This strategy, such as it was, ignored the reality of the Moravian's situation. Although Zeisberger explained the tactic by writing "there is nothing better to do here than to choke the ignorance of foolish people with good deeds," John Heckewelder offered a more truthful explanation years later when he noted that there was little choice but to provision war parties as "the warriors would have taken the food, anyway, and so serious a breach of Indian etiquette . . . would have brought immediate reprisals." 378

Unsurprisingly, however, this tactic did little to endear the Moravians to either side. ${ }^{379}$ Instead, the missionaries' actions placed the Moravians and their converts in an impossible position as both the British and the Americans correctly suspected they were aiding the enemy. In addition to the very real danger of inviting hostilities, hosting and supplying war parties strained the Moravian's ability to care for their own residents. In August 1777, Zeisberger worried that if the Wyandot war party that had arrived in Lichtenau a week earlier "stayed much longer they will eat us out of house and home" and sent a messenger to Gnadenhütten "to ask the Brothers and Sisters there for help supplying Provisions to the many people who are here, because our Brothers and Sisters are already quite exhausted." ${ }^{380}$ While he winced at the dwindling food stores, however, Zeisberger was reassured that the warriors did "not seem to be in much of a hurry to... have a battle with the White people" and declared "if they turned back it would be worth the trouble of entertaining them for so long." 381

Before the Shawnee Captain and his company left Lichtenau, he quietly warned Peggy that "there would be more bad times" although he "could not yet say when or what it would

\footnotetext{
378 Zeisberger, Moravian Mission Diaries, 395; Heckewelder, Thirty Thousand Miles, 136.

${ }^{379}$ Silver, Our Savage Neighbors, 265-66.

${ }^{380}$ Zeisberger, Moravian Mission Diaries, 400-1.

${ }^{381}$ Ibid., 401.
} 
be." 382 Zeisberger's diary makes clear that the Shawnee leader, despite having "spoken a great deal with them" shared his concerns with only Peggy, not the Moravians. ${ }^{383}$ When Peggy reported her brother's warning, Welapachtschiechen hurried to Goschachgünk to intercept the Captain before he returned home and ask "what he meant by this and what he had wanted to say." While the Captain may have been reluctant to elaborate on his warning in the Moravian village, when he and Welapachtschiechen sat down together at Goschachgünk the Captain shared his knowledge. The Moravians, he stated, "were in danger from the other Nations because of the great War Belt...which all the Nations except the Delaware had accepted." 384

The Shawnee's warning could not have come as a surprise to the Delaware. White Eyes grimly warned that the "Nations are preparing to speak very sharply with the Delaware and wanted to force them to join the war." 385 Pacifism and neutrality had both failed the Delaware and the Moravians. By refusing to align themselves with either the British or the Americans, they had drawn the wrath of both. The Moravians' vow to avoid becoming entangled in political matters long forgotten, Zeisberger agreed to help White Eyes send a plea for assistance and protection to the Americans at Fort Pitt. ${ }^{386}$ Because the chief was not literate, the burden of correspondence fell on Zeisberger. General Edward Hand, the commanding officer at Fort Pitt quickly assured White Eyes

You may depend that my Soldiers will not hurt your Women or Children . . . if any Nation strikes you on our account, I desire you will call on me and \& you shall be supported with as much power as you wish for. ${ }^{387}$

\footnotetext{
382 Ibid., 393.

383 Ibid.

${ }^{384}$ Ibid., 27, 393. The Wyandot formally sided with the British at a conference in June-July 1777; the Shawnee did the same in March 1778. This left the Delaware as the only neutral nation in the Ohio Valley.

385 Ibid., 456.

${ }^{386}$ Ibid., 457.

${ }^{387}$ General Edward Hand to White Eyes, October 1, 1777, in Frontier Defense on the Upper Ohio Frontier 17771778, Draper Series, Vol. 3 (Madison: Wisconsin Historical Society, 1912), 113.
} 
The missionary took the initiative to plead the Moravians' case with the Americans independently as well. In a letter penned on September 22, 1777, Zeisberger asked the commander to "let us know if we, the Christian Indians, or the Delaware are in any Danger \& if we have any Thing to fear of the white People," assuring him that if the Indians moved toward war the Moravians "should be obliged to separate ourselves from them." 388 Although Zeisberger's letters in 1777 stopped short of offering military alliance, both White Eyes and Zeisberger recognized that by accepting military protection from the Americans, the Delaware were forfeiting their claim to neutrality. And despite the Moravians' proclamations of neutrality, Zeisberger and Heckewelder continued to dispatch intelligence to the American forces at Fort Pitt, reporting enemy movements and signs of impending attacks. Whether their actions reflected sympathy to the American cause, a desire to protect their congregations from American attack, or a sense of loyalty to the Delaware, the Moravian missionaries knowingly placed themselves and their converts in the center of the conflict. The Moravian leaders in Bethlehem realized (much too late) that the Ohio missions had failed in one of the basic tenants of their mission. In a letter to the missionaries, bishop John Ettwein anxiously reported "we cannot conceal for you our concerns...It seems to us that you got yourself too much involved in the troubles of this world and thus are losing the character of a friend of all the world." 389

The following summer, Delaware leaders, led by White Eyes, cast their fate with the Americans and in September 1778 met with representatives of the Continental Congress at Fort Pitt. The resulting Treaty of 1778 promised Delaware statehood, full recognition of their land rights, and military protection of women, children, and the elderly as well as food, clothing, and

\footnotetext{
${ }^{388}$ David Zeisberger to General Edward Hand, in Frontier Defense on the Upper Ohio Frontier 1777-1778, Draper Series, Vol. 3 (Madison: Wisconsin Historical Society, 1912), 94.

389 John Ettwein, letter, John Ettwein Papers, Moravian Archives Bethlehem, PA, quoted in Wellenreuther and Wessel, introduction to Zeisberger, Moravian Mission Diaries, 80.
} 
weapons. ${ }^{390}$ In exchange, the Delaware would fight with the Americans. White Eyes agreed to lead an expedition of American soldiers against Fort Detroit and was granted a colonel's commission. ${ }^{391}$ The treaty proved to be a disaster. Upon learning of the negotiations, the British in Detroit refused to provide goods to the Delaware. When the Americans failed to uphold their promise of supplying the goods as agreed to by treaty, Captain Pipe and other leaders who harbored pro-British sentiments began to sway the Delaware people toward an alliance with the British. Furthermore, many Delaware were outraged that their leaders had committed them to fight on behalf of the Americans. Gelelemind maintained that he had never agreed to do so, claiming that "the Tomahawk was handed to me at Fort Pitt but not in a warlike manner," adding "I neither desired any Implements of War, all that I agreed to was to pilot the Army, 'til beyond our bounds." Gelelemind claimed that in his understanding of the agreement, "Capt. White Eyes with several others" would "go before the Army \& convey them to the Enemy in order to be of use to both Parties, in case they should desire to speak or treat with one another." 392

It is impossible to know precisely what transpired at the treaty talks. Americans had a long history of shaping treaties to benefit their own interests. White Eyes signed the treaty along with Gelelemind, and his subsequent actions give some hints as to how the Delaware understood the agreement. White Eyes joined the Americans in a march toward Fort Detroit, although his exact role is unclear. Whether Gelelemind truly misunderstood that he had committed Delaware warriors to the American cause, was intentionally misled, or backtracked after witnessing the outrage of his community is equally uncertain. And, indeed, it proved not to matter much at all.

\footnotetext{
${ }^{390}$ Wellenreuther, “White Eyes and the Delaware's Vision of an Indian State,” 159.

391 Schaaf, 200.

${ }^{392}$ Killbuck [Gelelemind] to George Morgan, January 20, 1779, in Louise Phelps Kellogg, Frontier Advance on the Upper Ohio, Draper Series Volume IV (Madison: The Society, 1916), 204.
} 
The treaty Delaware leaders signed at Fort Pitt was never presented to Congress for approval and White Eyes was soon murdered by the soldiers ostensibly under his command. ${ }^{393}$

With both Netawatwees and White Eyes gone, Captain Pipe abandoned neutrality and aligned his people with the British. Some Delaware belonging to the Turkey and Turtle clans abandoned the Americans and joined the British-allied Delaware fighting under Captain Pipe, although other segments of the Delaware remained loyal to the fledgling United States. ${ }^{394}$ While representatives of the Grand Council tried to bring the Wolf Clan back into the fold, they simultaneously struggled to avoid open hostilities with the Wyandot, Shawnee, and Mingo sympathetic to the British cause on one side and the white settlers who failed to discriminate between friendly and unfriendly Indians on the other. ${ }^{395}$

In the years following the Treaty of 1778 , Gelelemind remained a dedicated ally to the Americans. He sent his son and half-brother to be educated at Princeton and spent much of his time traveling to Fort Pitt, where he kept commander Daniel Brodhead informed about the Ohio Indian's evolving alliances and military expeditions. As a result, his standing in the community deteriorated as Captain Pipe convinced increasing numbers of Delaware to join with the British.

In April 1781, Brodhead, likely acting on Gelelemind's intelligence, launched an attack against British allied Delaware towns. A few weeks later, Brodhead wrote to Joseph Reed, then president of Pennsylvania’s Executive Council, "I surprized the Towns of Cooshasking \& Indaochaie, killed fifteen Warriors and took upwards of twenty old men, women, \& Children.” After the attack, Brodhead planned to "send for some craft from the Moravian Towns, \& cross

\footnotetext{
393 Schaaf, 200.

394 The soldiers told officials that White Eyes died of smallpox. However, a subsequent investigation revealed that the Indian chief had been assassinated. George Morgan, commissioner of Indian Affairs for the Continental Congress, condemned both the murder and General McIntosh, commanding officer of the soldiers who carried out the murder. Although many Delaware may have suspected foul play, the events surrounding White Eyes' death were not officially reported until 1784, years after his death.

${ }^{395}$ Wellenreuther, "White Eyes and the Delaware's Vision of an Indian State," 157-58.
} 
the River to pursue the Indians," but the volunteers in his expedition "conceived they had done enough" and instead the men "marched to Newcomers Town" where they "experienced great kindness from the Moravian Indians...\& obtained a sufficient supply of men \& Corn to subsist the men and Horses to the Ohio River." ${ }^{396}$ Brodhead also noted that "upon hearing of our Troops being on the Muskingum," Gelelemind and a Captain Luzerne "immediately pursued the Warriors, killed one of their greatest Villains and brought his scalp to me."397 This was a dramatic departure from merely providing intelligence to the Americans. While Gelelemind was not a member of the Moravian towns, his close affiliation with the missionaries was well known. Fearing that his life was in danger, Gelelemind fled to Fort Pitt where John Gibson offered him protection on a small island outside the fort.

Gelelemind's actions may have served as a catalyst for the ensuing sequence of events that shattered the vulnerable mission towns. Wyandot warriors swarmed Gnadenhütten and the Moravians were "plundered, stripped, and taken on a nightmarish long march with their congregations to the outskirts of Detroit," where they were placed on trial by the British for treason. ${ }^{398}$ The trial in Detroit highlighted how the outbreak of war had tangled the bonds of kinship and friendship in the Ohio region. When the British Council assembled to open the proceedings, Captain Pipe presented Major de Peyster a number of scalps, but as he did so voiced his reservations that "perhaps it was wrong that he had ruined these men, for they were his friends...they were his flesh and blood, his nation, and his color." 399 As the focus of the gathering turned to the treason charges against the Moravians, Pipe rose and entreated the

\footnotetext{
396 Daniel Brodhead to Joseph Reed, May 22, 1781 in Pennsylvania Archives, $1^{\text {st }}$ series, 9: 161.

${ }^{397}$ Ibid., 162. Brodhead's letter calls him “Captain Killbuck” rather than “Gelelemind.” Killbuck Sr. died in 1779, however, meaning that this was certainly Killbuck Jr., also known as Gelelemind.

398 Ibid.

${ }^{399}$ Zeisberger, Diary of David Zeisberger, 37. It is unclear precisely who the victims were, but given the timing and location as well as Pipe's speech it seems reasonable to assume that the scalps had been taken from Delaware allied with the Americans.
} 
commandant to "speak kindly to them, for they are our friends, and I hold them dear and should not like to see harm befall them." 400 The startled Major responded to Pipe's plea by enumerating "all of the complaints he [Pipe] had made against the Brethren," and demanded that the Captain "prove that his accusations were true and that the missionaries had corresponded with the Americans." ${ }^{401}$ Pipe responded that "there is something in the matter" but "they who are the ministers, are innocent, they have not done it of themselves, they had to do it." Furthermore, "it would now not again happen" as the Moravians were in Sandusky, where "it could no longer happen." 402

Acquitted but forced to resettle at Upper Sandusky, beyond the reach of Fort Pitt, the missionaries and Christian Delaware suffered near starvation. The Moravians' removal to Upper Sandusky weakened any lingering kin ties they held with the broader Delaware community. The Conners, who had been relocated with the Moravians, drifted away from the others and settled in Lower Sandusky, in a small Wyandot town populated with "many white prisoners." 403

Captain Pipe was clearly instrumental in bringing the Moravians to trial and forcing them to relocate in barren Upper Sandusky as the bitter winter storms approached. According to Moravian George Loskiel, he also "boasted publicly" that he had "taken the believing Indians and their teachers prisoners, and considered them now his slaves." ${ }^{404}$ Yet Pipe's actions demonstrate his willingness to honor the obligations of kinship and friendship, even as the war complicated these bonds. His obligations to those Delaware who joined him in fighting the Americans - and to his British allies - required him to address the Moravian's correspondence

\footnotetext{
400 Ibid., 38.

${ }^{401}$ George Henry Loskiel, History of the Mission of the United Brethren Among the Indians in North America. Translated by Christian Ignatius LaTrobe. (London: Printed for The Brethren's Society for the Furtherance of the Gospel, 1794), 166-7.

402 Zeisberger, Diary of David Zeisberger, 38.

403 Zeisberger, Diary of David Zeisberger, 76. Peggy Conner's relationship with her Shawnee brother is unknown.

${ }^{404}$ Loskiel, History of the Mission, 163. There is no indication that Pipe treated the Moravians or their converts as "slaves."
} 
with Fort Pitt, particularly if that correspondence was instrumental in leading American forces to attack Delaware villages. Nevertheless, Pipe attempted to balance his obligations of kinship and friendship by neutralizing the Moravian threat to British war efforts while still protecting the missionaries from British retribution. Pipe's assertion that the Moravians were forced to correspond with the Americans and were therefore innocent of treason suggests that he both acknowledged and respected the kinship bonds between the German missionaries and the neutral Delaware - bonds that obligated the Moravians to act on the Delaware's behalf. Pipe is portrayed as a villain in Moravian writings, yet his actions are comparable to Gelelemind's. Both men betrayed their kin in an effort to uphold a conflicting alliance with an outside party.

Rather than strengthening the Delaware and securing their place in the Ohio Country, the Delaware's complicated web of alliances and kinship bonds fractured their delicate unity as it became clear that they could not uphold all of the alliances they had built in the decade since the Seven Years' War. Netawatwees and other Delaware leaders invited the Moravians to their land as a means of reuniting their people and maintaining a useful ally. The decision to invite the Moravians to the Ohio Country had been controversial from the beginning; the Delaware Council did so believing that the benefits outweighed the costs and confident that they could force the Moravians to leave their land once a Moravian alliance was no longer needed. For these leaders, the Moravians were merely part of a long-term strategy to secure Delaware land and bolster their political standing in the region. What they failed to foresee was that some prominent leaders - such as Isaac Glikhicken, Welapachtschiechen, and Gelelemind - would be drawn to the Moravians and seek to integrate more closely into the mission towns. While the Delaware may have been physically reunited, deep divisions remained. 
Isaac Glikhicken and Welapachtschiechen continued to play important diplomatic and political roles in the region after they were baptized into the Moravian church. Even as they worked to maintain neutrality, their actions drew them closer to the Americans as Zeisberger and Heckewelder were slowly entangled in the Revolution. Indian leaders who committed themselves to the Moravians were no less dedicated to Delaware sovereignty and survival than their nativist peers, but they were willing to embrace a degree of cultural change and assimilation that other leaders rejected. These leaders remained dedicated to the Moravian alliance as a means of protecting their people, even as their decision eroded Delaware political unity. Unfortunately, the Americans' declaration of independence undermined the Moravians' political influence at the time the Delaware needed it most. 


\section{Chapter 5 \\ "Years of Blood": The Collapse of the Delaware-Moravian Alliance}

Writing years after the war ended, Moravian scholar Edmund de Schweinitz reflected "The last years of the Revolution, in the West, were years of blood...murders were committed in every direction." ${ }^{405}$ In the bitter winter of 1782 , the former residents of the Ohio mission towns struggled to survive after their forced relocation outside of Detroit. As food supplies dwindled and their cattle died of starvation, several Indians decided to return to the mission towns in hopes of scavenging crops from their abandoned fields. On the morning of March 6, 1782, the Indians worked quickly, as "some gathered the corn in heaps; some bagged it; while others stored what could not be transported in such rude but safe garners as the forest afforded." 406 Their work came to an abrupt halt when a contingent of roughly one hundred and sixty militia men appeared at the edge of their fields.

In missionary John Heckewelder's telling of events, the Indians "received the militia with joy and escorted them to Gnadenhütten." ${ }^{207}$ The Delaware leader Welapachtschiechen, who now went by the name Israel, was well aware that the Moravian missionaries had been providing information to the Americans for months and hoped that "the Americans were come to deliver the Christian Indians from their troubles." Israel quickly set about convincing the militia that the Indians were friends of the Americans. ${ }^{408} \mathrm{He}$ presented "a Number of Belts \& Strings of Wampum, which he had received from Time to Time of divers Agents and Commanding Officers, all tending to Friendship \& Unity between the States \& the peaceable Delaware part of

\footnotetext{
${ }^{405}$ Edmund De Schweinitz, The Life and Times of David Zeisberger: The Western Pioneer and Apostle of the Indians (Philadelphia: J.B. Lippincott \& Co., 1871), 538.

${ }^{406}$ Ibid., 540-1.

${ }^{407}$ Ibid., 542. It is unclear how many men were in David Williamson's party. Sources offer conflicting numbers, ranging from 160-300. See Rob Harper, "Looking the Other Way: The Gnadenhütten Massacre and the Contextual Interpretation of Violence," The William and Mary Quarterly, Third Series, 64 no. 3 (July 2007): 622, n. 1, for a summary of primary sources that give different figures.

${ }^{408}$ De Schweinitz, 541.
} 
the Indians." ${ }^{09}$ Israel had "no doubt left" that the Indians "would be received as Friends." He hoped that "God had prepared a Way \& place for them, where they could enjoy Peace" and that after "they arrived at such a Place, the Brethren in Bethlehem would soon send them Teachers." ${ }^{110}$ When some of the soldiers "were inquisitive as to politicks," Israel and Isaac Glikhicken addressed "every Question in a most satisfactory manner" so that the men might become "fully acquainted with these Christian Indians in every Respect." 411

As the nearly one hundred Christian Indians gathered in the center of Gnadenhütten, the militia surveyed "the Plunder they might be Master of, if these Indians could be condemned, and put to Death." 412 Having "taken care to get Possession of all Rifles, Hatchets, Axes" that the Indians carried, the militia held "a Councill of the Manner in which they should be put to Death." A number of soldiers - perhaps even "the Major part" - argued that the Moravian Indians were innocent and "recommended to the Protection and Charity of all as good and true Christians." But their protestations were no match for the vehement hatred of those in the group who "declared themselves having a just right to revenge" for the loss and suffering they had experienced during the war. Eventually the men who argued against executing the Moravians "wrung their Hands, and called God to wittness that they were not guilty of the Blood of these innocent creatures" before retreating. ${ }^{413}$ As the Indians knelt to pray and sing hymns together, the remaining militia men debated whether they should burn their captives alive or scalp them. Arriving at a consensus, the Americans bludgeoned ninety-six men, women, and children to

\footnotetext{
409 John Heckewelder, Thirty Thousand Miles with John Heckewelder, ed. Paul A. W. Wallace (Pittsburgh: University of Pittsburgh Press, 1958), 192.

${ }^{410}$ Ibid.

${ }^{411}$ Ibid., 193.

412 Ibid.

${ }^{413}$ Ibid., 193-4.
} 
death and scalped each one before throwing the bodies into a nearby house and burning it to the ground.

By 1782, the Delaware-Moravian political alliance was deeply strained. The Brethren had never enjoyed unanimous support from Delaware leaders; with the deaths of Netawatwees and White Eyes, the missionaries lost their strongest advocates. Even after Captain Pipe led significant numbers of Delaware warriors into a formal alliance with the British and forced the Moravians into exile, however, a faction of the Delaware remained committed to the Brethren. The Gnadenhütten Massacre demonstrated the Moravians' inability to provide political or spiritual protection to the Delaware who had placed their faith in the Brethren. The aftermath of the Seven Years' War strengthened the Delaware-Moravian alliance, but the Revolutionary War shattered it.

Historians often point to the Gnadenhütten Massacre as a defining example of the racial violence that characterized much of the bloodshed in the west during the American Revolution. ${ }^{414}$ However, the massacre also symbolized the sharp divisions between the urban east and the rural west and the breakdown of political authority in the outer edges of the state. In the final years of the war, western settlers increasingly rejected the authority of eastern political and military leaders in favor of a "brash majoritarian localism" that often rode roughshod over those who failed to adhere to popular opinion. ${ }^{415}$ Historian Rob Harper argues that the "trauma of war, together with the chronic insecurity of frontier existence" yielded "hostility and even

\footnotetext{
${ }^{414}$ Both Peter Silver and Patrick Griffin have offered this interpretation. See Peter Silver, Our Savage Neighbors, and Patrick Griffin, American Leviathan: Empire, Nation, and Revolutionary Frontier (New York: Hill and Wang, 2007).

${ }^{415}$ Rob Harper, "Looking the Other Way: The Gnadenhütten Massacre and the Contextual Interpretation of Violence," The William and Mary Quarterly 64, no. 3 (July 2007), 634. Also see Saul Cornell, The Other Founders: Anti-Federalism and the Dissenting Tradition in America, 1788-1828 (Chapel Hill: The University of North Carolina Press, 1999).
} 
violence against dissenters." ${ }^{416}$ By focusing solely on the motives of white men who killed neutral and allied Indians, historians fail to fully appreciate the social and political context in which this violence occurred. The Delaware had invited Moravian missionaries to the Ohio Country in hopes that they would be valuable allies in the Indians' quest to secure a homeland. Throughout the Revolutionary War the Moravians maintained significant political connections with elite politicians in Lancaster and Philadelphia. When rural settlers and their elected leaders rejected eastern leadership and created their own course of action, however, the Moravians found their ability to protect the mission towns severely curtailed.

The breakdown of eastern authority in the west had dire consequences for the Moravian missionaries and their Native converts in the Ohio Country. Since their arrival to Pennsylvania in the 1740s, the Moravians had weathered controversy and persecution. In the early years, conflict stemmed from fears of their unorthodox religious beliefs and practices; with the outbreak of the Seven Years' War, public outrage came from the belief that the Moravians were secretly arming French-allied Indians. Throughout the Seven Years' War, settlers had eyed Moravians and their Indian converts with suspicion. Native peoples frequently passed through Bethlehem and the surrounding Moravian communities as they traveled from western Pennsylvania and the Ohio Country to the eastern towns of Lancaster and Philadelphia. Indians who resided in the mission towns maintained close contact with their friends and kin outside of the community. Moravian missionaries failed to join local militias. Combined, these factors fed a narrative in which the Moravians assisted French-allied Indians to drive settlers from the land. Following the war, the Moravians relocated their missions in hopes of shielding their converts from both the "corrupting influence" and the physical threat that they feared white society posed. Unwittingly, they established their new missions in what would become the hotly contested lands between the

${ }^{416}$ Harper, 634. 
British stronghold of Detroit and the American held Fort Pitt. Two decades after the Seven Years' War, the Moravians and affiliated Indians again found themselves the objects of suspicion.

During the Revolutionary War, opposition to the Moravians was multifaceted. Some patriots believed that the Moravians were Tories - or, if not loyal to the Crown, not sufficiently dedicated to the American cause. Moravian leaders' attempts at neutrality and resistance to Pennsylvania's Test Act and Militia Law made them easy targets for charges of loyalism. In the west, the Moravians' continued relationships with Native peoples infuriated settlers who suffered at the hands of Ohio Indians. The fundamental difference between the violence against the Moravians during the Revolutionary era compared to earlier eras, however, was that it came exclusively from their neighbors. In the 1740s, prominent religious leaders led the charge against the Moravian church; during the Seven Years' War, well-known politicians accused the Brethren of arming Native peoples. But during the American Revolution, elite leaders intervened on the Moravians' behalf. Violence against Moravians during the Revolution highlighted the "fractures between elite and rank-and-file patriots" and limited the extent to which the Moravians' carefully cultivated political allies were able to help them. ${ }^{417}$

Scott Paul Gordon argues that attacks on Moravians during this period came from "plebian patriots" who used the revolutionary crisis to pursue agendas that their "betters" had not anticipated and were powerless to stop. Their harassment was "rooted in religious intolerance and a greed for land" rather than a sincere belief that Moravians were loyalists. ${ }^{418}$ While the Moravians suffered from the economic downturn brought about by the war - just like their

\footnotetext{
417 Scott Paul Gordon, "Patriots and Neighbors: Pennsylvania Moravians in the American Revolution" Journal of Moravian History, 12 no. 2 (2012): 122. Gordon's article examines Moravian communities in eastern Pennsylvania. Many of his conclusions can be applied to western Pennsylvania and the Ohio Country, however.

${ }^{418}$ Ibid., 111.
} 
neighbors - Bethlehem's large buildings and numerous shops suggested prosperity and bred envy in the surrounding communities. If the situation for the Moravians in Bethlehem was concerning, it was even more ominous in the mission towns farther removed from political elites on the eastern seaboard. Following the Gnadenhütten massacre in 1782, John Heckewelder suggested that the murderers were motivated primarily by the belief that when they "killed the Indians," the "country would be theirs." 419

While "elite and rank-and-file patriots" were splintered in their opinions of and approach toward Moravians, the church community struggled to determine how they should respond to the American Revolution. Katherine Carté Engel argues that in the years leading up to the Revolution, the dissolution of the General Economy and subsequent "transformation of Bethlehem's economic life" resulted in “turning leaders' attention away from regional and international events and toward the life of the community." ${ }^{420}$ Bethlehem, which had always played an active role in the regional economy, integrated even more closely following the Seven Years' War. Nonetheless, those in the settlement town remained socially distinct from their neighbors. The Revolution placed the Moravians in a difficult position. Moravian leaders were opposed to war in principle, but their desire to remain neutral stemmed largely from the global nature of the church. In 1749, the British Parliament had formally recognized the international Unity, thus enabling the Moravians to work throughout the British Empire with the Crown's blessing. With mission fields scattered throughout the world, the Moravian church had a vested interest in the stability of the British Empire; any affiliation with the American rebellion could hold consequences for missions in other British colonies. Individual Moravians in the American

\footnotetext{
419 John Heckewelder, A Narrative of the Mission of the United Brethren Among the Delaware and Mohegan Indians, From Its Commencement, in the Year 1740, to the Close of the Year 1808 (Philadelphia: McCarty \& Davis, 1820), 318.

${ }^{420}$ Katherine Carté Engel, Religion and Profit: Moravians in Early America (Philadelphia: University of Pennsylvania Press, 2011), 216.
} 
colonies may have supported the American's cause, but the Church feared any formal action that could jeopardize support for their missions in London. ${ }^{421}$

As the American rebellion against the British grew, Moravians throughout Pennsylvania struggled alongside those in the Ohio Country to maintain their neutrality - and convince their neighbors that they remained above the fray. Where the Ohio missions were forced to contend with Native peoples who urged them to declare sides, those in eastern Pennsylvania faced backlash from their Euro-American neighbors. The church was also plagued by internal dissent. Early on, some members of the church voiced their support for American independence. Moravian leaders urged their congregations to adhere to the church's formal policy of neutrality. In May 1775, the Provincial Helper's Conference counseled its members to "abstain from any participation" in war efforts and "avoid any occasion of becoming unnecessarily involved" in political matters. After the signing of the Declaration of Independence, the Litiz congregation determined that it was "best to remain absolutely inactive" and refuse to "renounce all allegiance to the King of England." 422

Moravian leaders may have been united in their calls for neutrality, but individual members did not always fall in line. William Henry emerged as one of the most vocal proponents of American independence. Soon after the Boston Massacre in 1770, Henry signed Lancaster's non-importation pledge in protest. He joined Lancaster County's Committee of Correspondence and Observation when it was established in 1774 and ran for a seat in the Pennsylvania Assembly in 1777. Following his successful campaign, Henry served in the Assembly and as the treasurer of Lancaster County - a position that required him to manage funds to supply military efforts against the British. William Henry was not the only man to go against the wishes of

\footnotetext{
${ }^{421}$ Ibid., 218.

${ }^{422}$ Provincial Helpers Conference to Town and Country Congregation, June 19, 1776, in Kenneth Hamilton, John Ettwein and the Moravian Church During the Revolutionary Period (Bethlehem, PA: Times Publishing, 1940), 243.
} 
Moravian leaders and openly support the Americans in their armed rebellion, but he was the most prominent. Bishop John Ettwein, conveniently overlooking the Moravians' actions during the Seven Years' War, reminded congregants that it was “a firm principle of the Brethren's Church not to bear arms" and sought to maintain a hard line against those who sympathized with the American's cause. His task became significantly more difficult in June 1777, when the Pennsylvania Assembly passed the Test Act and the Militia Law.

Pennsylvania's Test Act was designed to determine those in the state who were committed patriots and those who remained sympathetic to Britain. It required all colonists to swear that they would "renounce \& refuse all Allegiance to George the Third King of Gr.Br. his heirs \& Successors" and remain "faithful \& bear true Allegiance to the Common Wealth of Pennsylvania as a free \& independent State." The limitations of this act in rooting out loyalists are obvious; nonetheless, it proved problematic to the Moravians and other peace churches such as the Mennonites and Schwenkfelders. The law ordered that any man who "shall refuse or neglect to take or subscribe to the oath as herein states shall be ineligible to occupy any office or important post in this State, to serve on juries, to collect any debts by legal methods, to vote or be elected...and is to be disarmed." ${ }^{423}$ Many Loyalists had their property seized by patriots during the war; the targeting of Moravians, Mennonites, and others shows that to be anything other than a gun-toting patriot opened one to attack as well. Philadelphia lawyer Lewis Weiss cautioned Ettwein that "Cruel Neighbors hunger and thirst after your estate" and warned that they would “certainly devour them in a few Months without the Assembly will interpose." ${ }^{224}$ In a letter to

\footnotetext{
423 Ibid., 252-3.

${ }^{424}$ Lewis Weiss to John Ettwein, October 1778, in Hamilton, John Ettwein, 297.
} 
the Pennsylvania Assembly, Weiss warned that the Moravians faced "Banishment of their Persons \& Confiscation of their Estates" at the hands of settlers eager for their lands. ${ }^{425}$

The Moravians, like other peace churches in Pennsylvania, sought an exemption from the Test Act and Militia Law on the grounds that since its inception, the former colony had honored its citizens" "liberty of conscience." Ettwein and other church leaders may have espoused a belief in individual conscience, but they also believed that true Christians would find themselves unable to participate in warfare. The church warned its members that "no individual belonging to a settlement congregation, who should comply under any pretext whatever to take [the] test, could remain a communicant member." 426 This policy proved increasingly untenable. Even as Pennsylvania's patriots proclaimed their desire for "liberty," they demanded that the Assembly punish those who refused to participate in military efforts or renounce the British monarch.

In April 1778, County Lieutenant Wetzel arrested twelve Moravian men and imprisoned them in the Easton jail. According to Moravian historian J. Mortimer Levering, the "arrests were not made at Bethlehem nor even at Nazareth, but in Wetzel's own neighborhood at Emmaus" where he could do so "more easily and with less likelihood of immediate interference from higher quarters." 427 Wetzel paraded the men "like criminals with much show of guard and restraint, through Bethlehem.” All of the men were eventually released, but threatened with future arrest if they failed to swear their oath and pay the required penalty. ${ }^{428}$ If the Moravians felt persecuted by their neighbors in general, Wetzel's actions were particularly galling. John Wetzel had been born into a Moravian family and raised in the community; it was only as an

\footnotetext{
425 Petition to the Pennsylvania Assembly, October 1778, in Hamilton, John Ettwein, 304-5.

${ }^{426}$ John Ettwein, "Short Account of the Disturbances in America and of the Brethren's Conduct and Suffering in this Connection," (1781) in Hamilton, John Ettwein, 254.

427 Joseph Mortimer Levering, A History of Bethlehem, Pennsylvania, 1741-1892, with Some Account of Its Founders and Their Early Activity in America (Bethlehem, PA: Times Publishing Company, 1903), 498. ${ }^{428}$ Ibid.
} 
adult that he rejected the church and its teachings. What motivated Wetzel to leave the church is unclear, but he seemed to harbor a deep resentment toward the community. Wetzel used his standing in Northampton County to harass the Moravians, forcing them to provide "progressively more expensive proofs the Moravian sympathy to the cause." 429

As they had in the past, Moravians leaned on their political allies for support and quickly received it. On May 22, 1778, George Bryan, Vice President of Pennsylvania’s Executive Council, wrote to Wetzel informing him "The Moravians and Schwenkfelders have been very urgent for the Assembly to relax the Test and free them from the abjuration part" and that "it is the wish of the Government not to distress them by any unequal fines, or by calling them, without any special occasion happens, to take the oath at all." ${ }^{430}$ But only weeks later, on September 7, Constable Walp arrived "armed with notices...to be served upon all of the men at Bethlehem, Nazareth, Gnadenthal and Christianbrunn to appear...to take the oath or take the consequences." ${ }^{431}$ Ettwein hurried to Easton to consult "with sensible men among the county officers" and then proceeded to Philadelphia "to take counsel with the executive heads of the State Government.” Days later, he returned with William Henry at his side and assurances that the summons were "unauthorized, illegal in method, and an impertinent assumption." Henry rode to Allentown, demanded that the local authorities "retract their summons," and informed them that "they need not expect any of the summoned men." 432 This outcome highlights how politically connected the Moravians remained in the late 1770s, even as their neighbors eyed them with suspicion. Similar summons had been issued to Mennonite farmers in the local Saucon Valley; in striking contrast to the Moravians, these German pacifists were forced to appear

\footnotetext{
${ }^{429}$ Engel, 222.

${ }^{430}$ George Bryan to Lieutenant Wetzel, May 22, 1778, in Levering, 499.

${ }^{431}$ Levering, 501.

${ }^{432}$ Levering, 501.
} 
before the squires and paid significant fines. ${ }^{433}$ When settlers criticized local authorities for their failure to bring Ettwein to heel, they reportedly defended themselves by claiming that he had "too many friends in the Assembly and Council."434

The Moravians could claim "friends" in the upper echelons of America's fledgling government, but their protection was far from assured. As early as 1775, Benjamin Franklin reminded church leaders that "there were among the Brethren many who did not hold it unlawful to arm in a defensive War," and urged them to allow "any such among your young Men” to "learn the military Discipline among their Neighbors, as this might conciliate those who at present express some Resentment." 435 In 1778, Ettwein wrote to his friend Henry Laurens, then president of Congress, for assistance. Laurens gently rebuked his request and "advised that the community make a formal petition to the Pennsylvania Assembly for relief, rather than seek to use back channel influence." ${ }^{436}$ Moravians in Bethlehem remained relatively sheltered, but Moravian congregations in other areas were not so fortunate. As a result, many Moravian men did swear the oath of allegiance and serve in the military - not because they rejected church leaders who urged them to remain outside of the conflict, but because they had little choice. The Moravians' carefully nurtured relationships with politicians in Philadelphia proved unable to protect them from local authorities as the dynamics of the war shifted power structures in Pennsylvania. ${ }^{437}$

At the same time, some Moravian men did not hesitate to swear the oath, despite the urging of their religious leaders to refrain from doing so. William Henry was quick to take the

\footnotetext{
433 Ibid.

${ }^{434}$ Ibid., 503.

${ }^{435}$ Benjamin Franklin, The Papers of Benjamin Franklin, Vol. 22, ed. William B. Wilcox (New Haven: Yale University Press, 1982) in Engel, 223.

436 Engel, 223.

${ }^{437}$ Gordon, "Patriots and Neighbors."
} 
oath. To the consternation of leaders in Bethlehem, William Henry "did all he could to persuade irresolute Brethren in Lancaster and Litiz and also Bethlehem to [take] the test." ${ }^{438}$ Ettwein observed that Henry "was exceedingly busy, these days, in an effort to free the Brethren from their scruples against taking the oath" and feared "he had had success with many." The Board of Elders decided to "let those Brethren, who felt they could take the test, decide for themselves" and even went so far as to "advise those employed in public enterprises to do so." But Ettwein could not bring himself to accept this decision, writing "I saw quite plainly that we would create a dissension in the Church and that offense and scandal would result." ${ }^{439}$ Henry not only encouraged his brethren to take the oath - he was the man charged with documenting those who took the oath in Lancaster County and reporting it to the Assembly. Ettwein bitterly accused Henry of using his position in the Assembly to undermine the Brethren's petition to be exempt from bearing arms in the conflict. The state refused to accept that members of the church deserved a blanket exemption as many Brethren (such as Henry) agreed to take the oath.

Yet at the same time, Henry used his influence to protect Moravian men who found themselves harassed by local politicians for their refusal to swear the oath or participate in military exercises. ${ }^{440}$ Ettwein may have dismissed Henry's actions as self-serving or craven, but he was not above seeking Henry's help when the Moravians came under increased threat after the Assembly passed a punitive addition to the Test Act that "licensed magistrates to imprison and confiscate the property of those who refused to sear the oath." Ettwein appealed to Henry, "I pray you to be an Advocate for tender consciences \& the suffering Members of Christ,"

\footnotetext{
${ }^{438}$ Hamilton, John Ettwein, 295.

${ }^{439}$ Ibid., 301-2.

${ }^{440}$ Gordon, "William Henry of Lancaster and Mixed Living," 31.
} 
admitting that "you are the only one in the present Assembly whom I know \& can put confidence in. ${ }^{441}$

Ettwein was open in his condemnation of Brethren who chose to take the oath and questioned the faithfulness of those in the town and country congregations, but even settlement communities such as Bethlehem were drawn irrevocably into the war. In December 1776, George Washington evacuated from New York and the Continental Army established a hospital in Bethlehem. Sick and wounded soldiers filled the Single Brothers house as the Moravians hustled to provide food and nursing services. The Choir house functioned as a hospital until March 1777; it was reestablished later that autumn when Washington established his winter encampment at Valley Forge. ${ }^{42}$ Nursing Continental soldiers did little to save the Brethren from their neighbors' resentment. In fact, many soldiers who witnessed able-bodied young men working in the relative safety of Bethlehem's hospital rather than facing the British on the battlefield considered them cowards. But if those engaged in armed fighting denounced the Moravians as spineless due to their unwillingness to bear arms, Moravians viewed their willingness to stand for their principles as proof of their manhood. As John Ettwein wrote to Matthäus Hehl, the minister of the Lititz congregation, "If we now endure some suffering for the sake of our principles and freedom, we shall approve ourselves in the sight of God and man; if we permit ourselves to be frightened and unmanned by threats, we must continue a shameful existence. ${ }^{\prime 43}$

\footnotetext{
${ }^{441}$ Ibid., 32-3.

${ }^{442}$ Engel, 224-25. Although the Choir houses for married couples and children had been dismantled when the General Economy ended, unmarried adult men and women continued to live in their respective Choir houses. Engel argues that the American Revolution was "a far less significant event for the Moravians than the Seven Years' War that preceded it had been, because their much reduced missionary work no longer placed Bethlehem at risk" whereas the "earlier conflict had struck at the heart of Moravian religious life by transforming the way that the Unity could carry out its religious work."

${ }^{443}$ John Ettwein to Matthäus Hehl, June 1, 1777[?], in Hamilton, 324-5.
} 
Ettwein's defense of Moravian manhood spoke to a larger debate over masculinity and manhood during the American Revolution. Colonial America's "dominant ideal of manhood was the traditional patriarch who devoted himself to governing his family and serving his community." ${ }^{444}$ His power within the household was nearly absolute, though he was expected to defer to religious and civic authorities. This understanding of manhood required economic and political independence - achieved through property ownership - and control of one's dependents. ${ }^{445}$ Needless to say, Moravian men had not fared well in the eyes of their peers who accepted these prescribed parameters of masculinity. Under the General Economy, men did not own independent households or exercise significant oversight of their wives and children. In the mid-eighteenth century, however, the Great Awakening ushered in a wave of evangelical revivalism, and with it, an alternative vision manhood. As Janet Moore Lindman notes, "the emergence of evangelical revivalism led to a new form of manhood, one based on Christian concepts of humility, piety, and sobriety." ${ }^{446}$ Moravian gender constructs remained distinct from this new understanding of manhood as well, however. The Brethren emphasized a belief that all souls were female, and thus, “masculinity was temporal.” After death, a man's "earthly form would fall away, and his female soul would then be married to the Eternal Bridegroom." ${ }^{447}$ Men routinely cried at religious gatherings and frequently exchanged kisses with their Moravian brothers. ${ }^{448}$ Even men who moved away from the "traditional patriarch" model of manhood during the Great Awakening often looked askance at Moravian men. As one writer noted

\footnotetext{
${ }^{444}$ Mark E. Kann, A Republic of Men: The American Founders, Gendered Language, and Patriarchal Politics (New York: New York University Press, 1998), 5.

445 Janet Moore Lindman, "Play the Man... for Your Bleeding Country": Military Chaplains as Gender Brokers During the American Revolutionary War," in Thomas A. Foster, ed., New Men: Manliness in Early America (New York: New York University Press, 2011), 237

${ }^{446}$ Ibid.

${ }^{447}$ Katherine Faull, "Masculinity in the Eighteenth-Century Moravian Mission Field: Contact and Negotiation," Journal of Moravian History 13 no. 1 (2013), 30.

${ }^{448}$ As Faull notes, kisses were "exchanged as a greeting, as a sign of love, as a sign of peace, and as a kind of medicine for the body and soul." Faull, Masculinity in the $18^{\text {th }}$ Century Moravian Mission Field, 41.
} 
dismissively, the Moravian men "take on rather effeminate manners...They laugh and weep within one breath." ${ }^{449}$

By the time of the Revolution, Moravians had abandoned their most controversial practices and teachings and edged closer to a more mainstream model of masculinity. They did so just as American ideals of manhood and family relationships underwent another evolution. The traditional patriarch, who exercised nearly absolute authority over his household, had come under attack as Americans began to see "tyranny" in new quarters. As the colonies edged toward war, Thomas Paine "denounced men who abused patriarchal authority to play the tyrant and keep women 'in a state of dependence' akin to slavery." ${ }^{50}$ Abigail Adams' famous call for husbands to "give up the harsh title of master for the more tender and endearing one of friend" came the following year. Judith Sargent Murray urged men to work toward "mutual esteem, mutual friendship, mutual confidence" with women. ${ }^{451}$ This new model of masculinity was in keeping with the Revolution's rhetoric of democracy and equality, but America's mainstream culture of manhood still required men to be independent and self-supporting. It also expected men to strenuously defend their independence and liberty - which in the context of war translated to military service.

Moravian men were determined to defend their liberty, but doing so did not include resorting to armed conflict. The Brethren's most pressing concern was religious freedom, and therefore the major threat to their liberty came from their neighbors and the Pennsylvania Assembly rather than the British. Their means of resistance came in the form of refusing to participate in violence. As Ettwein declared, men who allowed themselves to be intimidated and

\footnotetext{
${ }^{449}$ Quoted in Paul Peuker, "Wives of the Lamb: Moravian Brothers and Gender around 1750" in Masculinity, Senses, Spirit, ed. Katherine Faull (Lewisburg: Bucknell University Press, 2011), 46n24.

${ }^{450}$ Kann, 9.

${ }^{451}$ Ibid., 10.
} 
coerced into turning their back on their moral principles were "unmanned." His disdain for men who chose to take the oath was due to his belief that such men had acted of "selfwill, greed, ease, and a desire to escape the cross." ${ }^{452}$ Ettwein declared "I would rather permit myself to be hacked to pieces than go to war, butcher people, rob people of their property or burn it down" and argued that should God "permit anything to come upon us, He would surely give us a confident heart and patience in suffering." ${ }^{453}$ Despite his high standing in the church, Ettwein's position was complicated by the fact that the Board of Elders allowed men to rely on their individual conscience in deciding whether to swear an oath of allegiance to Pennsylvania or, eventually, to enlist in the fight against the British. Many Moravian men chose to take the oath. Some fought alongside their patriot neighbors. There is no doubt that some men were coerced into doing so, but others chose to take the oath or enlist because they were sincerely committed to the American cause. But whereas men outside of the Moravian church confirmed their manhood by marching into battle, Moravian men who participated in warfare faced the judgment of many in their own community. Refusing to take up arms proved that one had the strength to resist a corrupt world and accept suffering without fear; joining the ranks was a shamefully unmanly act.

In the late 1770s, Moravian missionaries in the Ohio Country were not troubled by debates of whether to take an oath of loyalty to the state or fearful of arrest for their refusal to bear arms. Nonetheless, their congregations confronted many of the same threats as those in eastern Pennsylvania. There was no longer any place for neutrality or pacifism in the Muskingum River Valley, although here it was the Moravian Indians who faced pressure to join the war from Native peoples rather than Americans. Perhaps most concerning to the missionaries was the growing awareness that the political alliances they had meticulously developed over

\footnotetext{
452 John Ettwein to Matthäus Hehl, June 1, 1777[?], in Hamilton, 325.

${ }^{453}$ Ibid., 326.
} 
many years no longer afforded them protection from the restless and angry settlers who vowed revenge for their family and friends killed by Indian war parties.

By the 1780s, state authority in western Pennsylvania and the Ohio Country - always somewhat uncertain - had nearly dissolved. The Americans maintained a series of forts, including Fort Pitt and Fort Laurens, but just barely. The forts were chronically understaffed and struggled to supply their garrison with even basic necessities. For a time, Fort Pitt held only one hundred ten men; the entirety of the American force in the Ohio Valley numbered just over two hundred. Commanders lacked the resources to conduct significant expeditions against British or Indian forces, and as a result area settlers had little motivation to support the Continental troops. County militias were routinely short on volunteers, and those who did muster were disinclined to accept orders from commanding officers. Men "refused to march east to serve when called up, and militiamen deserted their posts or did not turn out when ordered." ${ }^{254}$ Many declined to supply the fort with beef. Those who did often demanded "a most scandalous price" and were "not willing to part with them at any price other than hard money." ${ }^{455}$ Fort Pitt came to depend heavily on the meat provided by the Moravian Indians, one of their few steady providers. ${ }^{456}$ In the winter of 1780 , Zeisberger noted in the mission diary that "Brodhead, Commandant of Pittsburgh, sent a letter asking our Indians to go hunting for buffalo and elk... and take to the first and nearest Fort, and they would be paid for it." ${ }^{457}$ Daniel Brodhead resigned in 1781, citing his inability to "comply with the expectations of my superiors, and at the same time please a rabble." ${ }^{458}$ He was replaced by William Irvine, who upon his arrival surveyed the troops under

\footnotetext{
${ }^{454}$ Patrick Griffin, American Leviathan: Empire, Nation, and Revolutionary Frontier (New York: Hill and Wang, 2007), 164.

455 Ibid.

${ }^{456}$ Ibid.

${ }^{457}$ David Zeisberger, The Moravian Mission Diaries of David Zeisberger, 1772-1781, ed. Herman Wellenreuther \& Carola Wessel, trans. Julie Tomberlin Weber (University Park: The Pennsylvania State University Press, 2005), 545. ${ }^{458}$ Griffin, 164.
} 
his command and declared "I never saw troops cut so truly a deplorable, and at the same time despicable, a figure. ${ }^{~} 459$ Given the weak state of American forts, settlers in western Pennsylvania were forced to defend themselves as best they could.

When David Williamson gathered his men to march into Indian country in early 1782 , he was drawing from a county that had endured repeated attacks over the past three years. Estimates of how many militia men were present at the Gnadenhütten massacre vary widely, but even if the lowest figures are correct the Christian Indians were outnumbered. In an effort to demonstrate that they posed no threat, the Indians allowed the militia to easily gain control over them agreeing to hand over their weapons for "safekeeping" and submitting to being bound - until they found themselves sorted by sex and locked in two separate buildings. Heckewelder and other Moravians who wrote about the massacre tended to paint their converts as naïve innocents who unwittingly fell victim to the militia's cunning lies. This portrayal fails to give credit where it is due. The Moravian Indians had survived for years in often hostile environments; Israel and Isaac were not ingenuous leaders who took assurances at face value. The simple explanation for the Indians' actions is that they had faith that the alliances they had carefully nurtured with the Moravians would protect them from harm. By the time they realized otherwise, it was much too late.

When the militia first arrived outside of the mission town, John Martin, one of the Indian "Helpers" had been "over the hill, burying corn." Martin was alarmed when he saw evidence of "so many shod horses," but he approached the town and after "taking at a Distance a View... he observed to his Satisfaction that the Indians were up \& down the Streets together with the white People" and appeared "quite merry together." Martin reached the conclusion that "their Friends" the Americans had "come out of Love \& Friendship, to take them under their Protection \& Care"

${ }^{459}$ Ibid. 
so that they "should not perish in Sandusky." ${ }^{460}$ Israel and Isaac arrived at the same conclusion. Given the circumstances, it was an entirely logical reading of the situation. The militia men "pretended Friendship" and "hurried the Indians to get ready \& go with them." 461 They offered to help the Moravians "in carrying every thing along so that they might loose nothing," and loaded horses with the Indians' possessions. Some of the "big Boys among them...were playing all the Way with some of the White Lads." 462 These were not the actions Indians expected from men about to undertake a mass murder. And with good reason. It was not until after the militia had disarmed and confined the Indians that they gathered to debate what, exactly, they should do with their captives. The Christian Indians failed to recognize their dire situation because - at least initially - Williamson's men were not set on killing them. ${ }^{463}$ Many in the militia assumed, along with the Indians, that they were preparing to march the Moravians back to Fort Pitt. To Israel and Isaac, as well as many others, this was not an alarming scenario. William Irvine, the commander of Fort Pitt, was on good terms with the Moravians. John Gibson, the acting commander in Irvine's absence, had close ties with both the Delaware and Shawnee. Indeed, he had been married to a Shawnee woman who lived in Gekelemukpechünk until her death a few years prior. Furthermore, Gelelemind was currently living outside the Fort on Killbuck's island. The Moravian Indians had every reason to anticipate a friendly reception at the fort.

Once the Indians were secured in Gnadenhütten's cooper's shop and meeting house, Williamson informed his men "that he would leave it to their choice, either to carry the Indians as Prisoners to Fort Pitt, or to kill them." 464 Williamson was the elected leader of the expedition

\footnotetext{
${ }^{460}$ Heckewelder, Thirty Thousand Miles, 191.

461 Ibid.

462 Ibid., 193.

${ }^{463}$ It should be noted that members of the militia had killed one Indian when they first arrived outside of Gnadenhütten, before they had met with the Christian Indians or seen evidence of their "friendliness" toward Americans. The imprisoned Indians were not aware of this death.

${ }^{464}$ Relation of Frederick Lineback \& c., 1782 in Pennsylvania Archives, 9: 524
} 
and had an eye to his own popularity and reputation. Months before, Williamson and his men had captured a small group of Moravian Indians and marched them to Fort Pitt, only to see their captives promptly released and allowed to return to the Ohio Country. Williamson was roundly criticized for his leniency, however unfairly, and this no doubt shaped his decision to defer to the wishes of his volunteers. More broadly, Williamson's actions can be seen in the context of an emerging democratic political culture that held popular opinion in high regard and maintained "little concern for the rights of those who deviated from it." ${ }^{465}$ Later reports emphasized that the decision to kill the Indians came only after extensive debate and that several men refused to participate in the murder. Joseph Doddridge, who was raised in Washington County and familiar with some of the men in Williamson's expedition, praised those who spoke in favor of sparing the Moravians as they deserved "honorable mention for their intrepidity" and claimed that many others wished to spare the Indians but "the fear of public indignation restrained them from doing so" as they "had not heroism enough to express their opinion." These men allegedly "retired from the scene of slaughter with horror and disgust." 466

The events at Gnadenhütten represent more than simply an outburst of racial violence. They are also an example of the breakdown of eastern authority and the new democratic ideals emerging in the west. Fort Pitt represented the authority of the state. Williamson's men chose to ignore it and determine their own course of action. Israel had meticulously laid out evidence that the Moravian Indians were friends and allies of the Americans in general and of commanders at Fort Pitt in particular, but the militia decided against marching the Indians east to verify his

\footnotetext{
465 Harper, 633-34.

466 Joseph Doddridge, Notes of the Settlement and Indian Wars of the Western Parts of Virginia and Pennsylvania from 1763 to 1783, inclusive, together a Review of the State of Society and Manners of the First Settlers of the Western Country (Pittsburgh: John S. Ritenour and William T. Lindsey, 1912), 201. Doddridge's account was first published in 1824, forty years after the massacre occurred. Doddridge was around twelve years old when the Gnadenhütten Massacre took place.
} 
claims. It is possible that the militia believed Israel was lying, but it is equally possible that they simply did not care if Fort Pitt's commanders considered the Moravian Indians allies. The volunteers were not inclined to defer to the appointed officers in Pittsburgh, and elected militia officials such as Williamson found their grasp on authority was often tenuous. The militia's actions fell in line with a rash of other events that challenged eastern authority. Only weeks before Williamson's men marched into Ohio, an official in Washington County wrote to Pennsylvania President Moore that many local militia "officers and privates... Refuse becoming subjects of this State." Others had not been commissioned as they had "objects against taking the Oath of allegiance." Furthermore, a "Large Mob" prevented local elections from taking place "by ballot, as the Law directs" and instead forced voters to declare their choice for militia leaders "Verbally." 467 Unsurprisingly, the elected leaders enjoyed a "great Majority" of the votes. Eliminating secret ballots allowed the mob to silence dissent and energized a "bullying approach to democracy" where a "particularly determined or outspoken cohort" could "make itself a majority, and a slim majority could become a virtual consensus." 468

Similar dynamics were at play when Williamson's men gathered for their "Councill." Doddridge declared that "the justice and humanity of the majority" was overrun by "the clamor and violence of a lawless minority." 469 This might not be entirely accurate, but sources agree that the decision was far from unanimous. It is possible that the dissenters had a number of reasons for not standing their ground. Perhaps they were not entirely convinced of the Moravians' innocence or they were sympathetic to those in the group who sought revenge for murdered family and friends. Maybe, as Heckewelder suggests, they were enticed by the prospect of returning home with valuable loot. But given the "bullying political culture" that reigned in the

\footnotetext{
${ }^{467}$ Marshal to Moore, February 4, 1782, in Pennsylvania Archives, 9: 484-5.

${ }^{468}$ Harper, 635.

${ }^{469}$ Doddridge, 201.
} 
west, it is likely that they were unwilling to risk their own well-being to save Indian lives. Whatever the case, Williamson's decision to put the fate of the Moravian Indians up for a democratic vote and the dissenters' reluctance to challenge their peers resulted in tragedy.

One of the most chilling aspects of the massacre was the fact that it did not take place in a frenzied outburst of violence but that the militia spent hours talking with their victims and then weighing arguments for and against execution. The night before the killing began, two of Williamson's volunteers informed the Indians that they would be put to death the following morning. According to Heckewelder, the Indians said "they were willing to dye, tho innocent" and asked for "a Days time for the purpose of praying and preparing for Death." They were granted only a few hours, which they spent "on their Knees praying and singing Hymns." 470 Two "young lads...endeavored to make their Escape" but were quickly "shot down under the Bank of the River below the Village." "711 One Indian who "had like to have made his escape at the expense of the life of one of the murders" managed to get his hands on a knife and "aimed at stabbing one of the men." ${ }^{472} \mathrm{He}$ too was shot. Aside from these incidents, however, it seems that the Indian men were dragged one by one to their execution with relatively little resistance. The Indians continued singing "as long as there were three alive." 473

Doddridge captured the sentiments of many when he wrote, "one can hardly help reflecting with regret that these Moravians did not for the moment lay aside their pacific principles and do themselves justice." ${ }^{474}$ It is hard to imagine an alternative outcome, as the Indians were outnumbered and unarmed; any violent rebellion surely would have encouraged

\footnotetext{
${ }^{470}$ Heckewelder, Thirty Thousand Miles, 194.

471 Ibid.

472 Doddridge, 192. This incident is not mentioned in any other account and may be apocryphal.

${ }^{473}$ Frederick Lineback, "Relation of what Frederick Lineback was told by two of his Neighbors, living near Delaware River above Easton, who were just returned from the Monaungehela" April 1782, in Pennsylvania Archives, 9: 524.

${ }^{474}$ Doddridge, 194.
} 
even those opposed to killing the Christians to defend their countrymen. But it is worth considering what the actions of the condemned Indians demonstrate about their beliefs and worldviews. While many of the massacre victims were women and children, the men included prominent leaders such as Israel Welapachtschiechen and Isaac Glikhicken. Both men were experienced warriors and had garnered respect for their bravery in battle. When Wyandot warriors had stormed the mission towns and forcibly marched the Moravians to Detroit only months earlier, they sent twelve men to secure Isaac "So great...was the fear which his name still inspired." Despite having numbers on their side, "these warriors manifested no little trepidation when he stood before them and heard the object of their coming." ${ }^{475}$ Isaac's reaction to the warriors is telling. After hearing what they had come to do, he responded "There was a time, when I would never have yielded myself prisoner to any man; but that was the time when I lived in heathenish darkness and knew not God. Now that I am converted to Him, I suffer willingly for Christ's sake." 476

If this line of reasoning is applied to the events at Gnadenhütten, it suggests that Isaac and his peers - may have seen their execution as a martyrdom for their faith. It also suggests that they had adopted a distinctly Moravian model of masculinity. Rather than resorting to physical violence in an attempt to save their lives (and the lives of their wives and children), the men spent their last hours "Exhorting one another to Steadiness" and "committed their Souls unto God, who had given them the Assurance that they should be with him forever." 477 The Christ figure stood as the ideal of masculinity for eighteenth-century Moravians, and the Indians' last hours at Gnadenhütten echo the story of Jesus in the Garden of Gethsemane the night before his

\footnotetext{
${ }^{475}$ De Schweinitz, 510.

${ }^{476}$ De Schweinitz, 510.

${ }^{477}$ Heckewelder, Thirty Thousand Miles, 194.
} 
crucifixion. The men accepted their plight, even if they cried out against it, and entered into a time of prayer not for their deliverance, but for their eternal salvation.

At the same time, the men's actions reflect the practices and values of their native culture. Warriors were expected to face death with stoicism; if taken captive, they were to show no fear and "partake in the merriment" of the execution ceremony, taunting and "contemptuously scoffing" their tormentors. ${ }^{478}$ The men met these expectations. None of the accounts contain any mention of Indians begging for their lives to be spared. ${ }^{479}$ The continued singing, even as they watched their friends and family killed and scalped one by one, speaks to their stoicism. Singing hymns may not be considered "scoffing" or "taunting" in the same way as throwing insults would be, but in this context it was an act of defiance. The Indians sang hymns praising Jesus in the face of Christian white men who were engaged in mass murder. It would be difficult for any observer to not question which men were the "savages" in this scenario - a point that many outraged writers made as word of the massacre spread east. Singing hymns also connected the Indians to the tradition of performing war songs as they faced the possibility of death in battle. This connection was not lost on the men carrying out the killing, some of whom described their hymns as war songs. ${ }^{480}$

The Gnadenhütten Massacre was one event in a series of attacks on Native peoples in the Ohio region during the early 1780s. After the militia finished their deadly task at Gnadenhütten, they marched back to Fort Pitt, where they forced aside the federal soldiers who attempted to shield a small group of American-allied Delaware and killed four Indians. Gelelemind was

\footnotetext{
${ }^{478}$ John Heckewelder, History, Manners, and Customs of the Indian Nations Who Once Inhabited Pennsylvania and the Neighboring States (Philadelphia: Publication Fund of the Historical Society of Pennsylvania, 1876), 201.

${ }^{479}$ In David Zeisberger's account of the massacre, he writes that Christina, a Mahican woman, flung herself at Williamson and begged him to save her, "but got for an answer that he could not help her." David Zeisberger, Diary of David Zeisberger, A Moravian Missionary Among the Indians of Ohio: 1781-1798. Vol. 1, ed. and trans. Eugene Bliss (Cincinnati: Robert Clarke \& Co., 1885), 80.

${ }^{480}$ Silver, 270. The Indians most likely would have been singing in Delaware. During his time at the missions, Zeisberger translated a number of German hymns into Indian languages.
} 
present at the time and managed to escape unharmed. Other groups of settlers in western Pennsylvania launched attacks against Shawnee communities, killing children and raping women. Some of the men who participated in the killing at Gnadenhütten later assembled under the leadership of William Crawford to kill a group of Delaware and Wyandot Indians living in Sandusky, close to where Zeisberger and the Moravian refugees resided. ${ }^{481}$

Irvine was not in residence at Fort Pitt when the Gnadenhütten Massacre took place in early March. He returned to Pittsburgh at the end of the month to find Native peoples outraged at the murders, troops preparing to mutiny over unpaid wages, and local militia men threatening to seize the fort and scalp acting commander John Gibson - a Moravian ally who had married to a Native woman. This set of circumstances perhaps explains why Irvine failed to vigorously pursue the perpetrators of the violence even after Congress and the state of Pennsylvania demanded an investigation into the massacre. The militia may not have constituted a threat to the fort under normal circumstances, but if the soldiers carried through with their threats of mutiny and refused to defend their post there was a very real possibility that the militia could succeed. Irvine would then be placed in the unenviable position of explaining how he lost the American outpost to American settlers. ${ }^{482}$ Irvine had been tasked with the investigation along with Dorsey Pentecost, a local politician who depended on the support of militiamen to keep him in office. Neither man had any interest in alienating the local inhabitants. Irvine had already drawn criticism a few months earlier when he ordered the release of a few Moravian Indians who had been captured by local settlers and marched to Fort Pitt; his tenuous standing in the community undermined his authority as a local leader. ${ }^{483}$

\footnotetext{
${ }^{481}$ Griffin, 168-9.

${ }^{482}$ Harper, 638.

${ }^{483}$ Ibid., 638-44.
} 
Irvine and Pentecost may have overestimated the degree to which local residents supported the massacre, however. Harper suggests that the decision to kill the Christian Indians at Gnadenhütten "stemmed not from a collective desire to kill but from widespread deference to the demands of an especially vocal and bloodthirsty faction." ${ }^{484}$ Heckewelder's early account of the massacre, written a few years after the event, asserted that "only a minority of the militia supported or participated in the slaughter" and other accounts corroborated this claim. ${ }^{485}$ Dorsey Pentecost spoke with some of the militia members who claimed that only "thirty or forty of the party [at most one in four] gave their consent or assisted in the Catastrofy." 486 David Zeisberger reported that "two men alone had accomplished the whole murder." 487 The exact number of participants will never be known, but the exact number is irrelevant - all sources agree that the decision was not unanimous and that some men refused to participate in the massacre. Not only were the men divided in their decision to kill the Christian Indians, but the public split in its reaction to the killing. Unsurprisingly, denizens of Pennsylvania's eastern towns denounced the murders. More tellingly, however, settlers in the Ohio region were also ambivalent. Pentecost observed that some in the community were "condemning" while others were "applauding the measure." ${ }^{488}$ Some local militia leaders denounced Williamson's men. Resident Edward Cook maintained that "the Better part of the Community" believed "the Perpetrators of that wicked Deed" should be punished and warned that "without something is Done by Government in the

\footnotetext{
${ }^{484}$ Ibid., 629.

485 Ibid., 630; Heckewelder, Thirty Thousand Miles, 193-4.

${ }^{486}$ Dorsey Pentecost to President Moore, May 8, 1782, in ed. Samuel Hazard, Pennsylvania Archives: Selected and Arranged from Original Documents, Vol. 9 (Philadelphia: Joseph Severns \& Co., 1854), 540.

${ }^{487}$ Zeisberger, Diary of David Zeisberger, 85. Zeisberger's information came from a white man who had been captured by Indians a few weeks after the massacre. While other sources suggest only a minority of the men carried out the massacre, it strains credulity to imagine only two men killed dozens of Indians while the others stood by.

${ }^{488}$ Dorsey Pentecost to President Moore, May 8, 1782, in ed. Samuel Hazard, Pennsylvania Archives: Selected and Arranged from Original Documents, Vol. 9 (Philadelphia: Joseph Severns \& Co., 1854), 540.
} 
Matter, it will Disgrace the Annals of the United States;" others accused the group of cowardice and mourned the loss of "our well-known friends." 489

Given the political dynamics of the region, however, neither Irvine nor Pentecost had any wish to take a public stance on the massacre, let alone work to bring the killers to justice. In a letter to his wife, Irvine urged her to "keep your mind to yourself" and "not express any sentiments for or against these deeds" calling on "all the ties of affection" to buy her silence. He claimed that "no man knows whether I approve or disapprove of killing the Moravians" and hoped desperately to keep it that way. He feared that if his wife made a statement, "it may be alleged, the sentiments you express may come from me or be mine." ${ }^{490}$ Indeed, it appears that Irvine himself was not sure of his feelings. Even as he shared details of the massacre, including the fact that that "many children were killed in their wretched mothers' arms" he still mused "whether this was right or wrong, I do not pretend to determine." ${ }^{491}$ As Irvine wrote his wife, "People who have had fathers, mothers, brothers or children, butchered, tortured, scalped, by the savages, reason very differently on the subject of killing the Moravians [that is, the Moravian Indians], to what people who live the interior part of the country in perfect safety do." ${ }^{492}$

Whatever his deepest feelings on the issue, acquiescing to the darker impulses of the western settlers proved the easier course of action. In April 1783, as war with Britain wound to a close, Irvine wrote to George Washington that many settlers were committed "never to make peace with the Indians" and shared his opinion that "it will be next to impossible to insure peace with them till the whole of the western tribes are driven over the Mississippi and the lakes,

\footnotetext{
${ }^{489}$ Edward Cook to President Moore, September 2, 1782, in ed. Samuel Hazard, Pennsylvania Archives: Selected and Arranged from Original Documents, Vol. 9 (Philadelphia: Joseph Severns \& Co., 1854), 629; William Croghan to William Davies, July 6, 1782, in Harper, 639.

${ }^{490}$ C.W. Butterfield, ed. Washington-Irvine Correspondence: The Official Letters Which Passed between Washington and Brig. General William Irvine and Others Concerning Military Affairs in the West from 1781-1783 (David Atwood: Madison, WI, 1882), 344.

${ }^{491}$ Ibid., 343 .

${ }^{492}$ Butterfield, 344.
} 
entirely beyond the American lines." ${ }^{493}$ Furthermore, he believed the removal "will not now be very difficult," and although it would "be attended with great expense" the cost would be "not so great as holding treaties." ${ }^{494}$ If Washington responded to Irvine, his words have been lost.

Irvine's observation that white settlers would never "make peace" with the Indians foreshadowed the years of warfare that would continue to plague the region. The Northwest Ordinance of 1787 organized the lands west of the Appalachian Mountains between the Ohio River and the Great Lakes into the Northwest Territory and outlined the process for admitting new states carved from this massive territory. The ordinance declared that "the utmost good faith shall always be observed towards the Indians' their lands and property shall never be taken from them without their consent... unless in just and lawful wars authorized by Congress." ${ }^{495}$ Predictably, the decade following the Revolutionary War saw a series of "just and lawful wars" that culminated in the 1795 Treaty of Greenville. The treaty, negotiated with a coalition of leaders from the Delaware, Shawnee, Wyandot and a number of other tribes, ceded two-thirds of the Ohio Country to the United States.

After the Treaty of Paris ended the Revolutionary War in 1783, Gelelemind and "a few Indian families, of the Delaware tribe" remained close to Fort Pitt. Johann David Schoepf, a German traveling through the new country, reported that "General Irwin had several times, and again today, given them to understand that they could leave the Fort if they desired, peace now being declared," adding that the General was eager to see them go, "their presence in several ways being burdensome." The Delaware "seemed not at all inclined to go," however,

\footnotetext{
493 Ibid., 149.

${ }^{494}$ Ibid., 149.

495 An Ordinance for the Government of the Territory of the United States Northwest of the River Ohio, Article 3 , National Archives, https://www.ourdocuments.gov/doc.php?flash=true\&doc=8\&page=transcript.
} 
“apprehending perhaps not the most friendly reception among their people." ${ }^{496}$ In June 1788,

Gelelemind and his family arrived at the Moravian mission in Pettquotting, along the Huron

River near Lake Erie, where David Zeisberger ministered to a small group of Indians.

Gelelemind explained that he had wished to join the Moravians years earlier but "knew not how to come" as many Indians in the Ohio Country still "wished his life." ${ }^{497}$ According to John

Heckewelder, Gelelemind "lived in a manner under their protection, yet never durst venture far from home" as many Indians outside of the mission town still "threatened revenge" and "might come across and kill him." ${ }^{998}$ Years had passed since Gelelemind first requested to join the Moravian church. When he asked again in Pettquotting, Zeisberger granted him permission. On April 12, 1789, Gelelemind finally received his baptism. He took the name William Henry, "a name long since given him by an honourable member of congress by that name." 499

William Henry had died in 1786, a few years before Gelelemind took his name, but until his death he continued to use his political influence to benefit the Moravians and their Indian missions. Following the end of the war, John Ettwein worked diligently to secure land for the Christian Indians in Ohio. Ettwein first petitioned the United States Congress in 1783, although his request was not taken up for discussion until 1785. It is probably not a coincidence that Congress agreed to consider Ettwein's petition at this time - William Henry had been elected to

\footnotetext{
${ }^{496}$ Johann David Schoepf, Travels in the Confederation, 1783-1784, Vol. 1, trans. and ed. by Alfred J. Morrison (William J. Campbell: Philadelphia, 1911), 276-7.

${ }^{497}$ Pettquotting Diary, June 20, 1788, Moravian Archives Bethlehem, PA, quoted in Gordon, "Killbuck-Henry Family Legend Part 2," 6.

${ }^{498}$ John Heckewelder, "Names which the Lenni Lenape or Delaware Indians, who once inhabited this country, had given to Rivers, Streams, Places, \&c., with the now States of Pennsylvania, New Jersey, Maryland, and Virginia; and also Names of Chieftains and distinguished Men of that Nation; with the Significance of those Names, and Biographical Sketches of some of those Men" Transactions of the American Philosophical Society, Vol. 4 (1834), 393.

${ }^{499}$ Ibid.
} 
the United States Congress in $1784 .{ }^{500}$ It was not until June 1, 1796, that the United States

Congress finally approved an act granting the Society of United Brethren for Propagating the

Gospel Among the Heathen

three tracts of land of four thousand acres each, to include the towns of Gnadenhütten, Schoenbrun, and Salem, on the Muskingum, in the State of Ohio, in trust for the sole use of the Christian Indians formerly settled there.... including Killbuck and his descendants, and the nephew and descendants of the late Captain White Eyes, Delaware chiefs." $" 501$

President John Adams signed the act on February 24, 1798. These tracts were a significant addition to the five thousand acres near Lake Erie that the State of Pennsylvania had granted the Society in 1790 .

The relationship between the Henry family and Gelelemind continued for years after William Henry's death. When Congress created a commission to locate appropriate sections of public land for the Moravian Indians, William Henry II sat at the head of the board. In 1797, Henry II traveled to the Ohio Valley to assist in surveying the land set aside for the Indian's resettlement. Upon his arrival, “several of Killbuck's children” greeted him with "supplies of

\footnotetext{
${ }^{500}$ Henry sat on the committees for Coinage and Indian Affairs. Henry acquired quite the resume over the course of his life. His entry into public office came in 1758, when he was elected a Justice of the Peace for Lancaster County. In 1765, he became the Assistant Burgess of Lancaster - a position he held for the next decade. He simultaneously served as an Assistant Justice of the Country Clerks in 1770, 1773, 1777; the Canal Commissioner in 1771, a member of the PA Assembly in 1776 and sat on the Council of Safety of Pennsylvania in 1777. He was the President Judge of the Court of Common Pleas, Treasurer of Lancaster County, Assistant Commissary General, a confidential advisor of the Board of War. During the war, Thomas Paine lived in the Henry household until Ann Henry deemed his "indolent and intemperate habits" to be "intolerable." Upon William Henry's death, his wife Ann assumed his duties as the Treasurer of Lancaster County. Ann Henry was the first woman to hold public office in the state of Pennsylvania. See Francis Jordan, The Life of William Henry of Lancaster, Pennsylvania, 1729-1786, Patriot, Military Officer, Inventor of the Steamboat (Lancaster, PA: Press of the New Era Printing Company, 1910). ${ }^{501}$ Walter Lowrie, ed. American State Papers: Documents, Legislative and Executive of the Congress of the United States in Relation to the Public Lands, from the First Session of the First Congress to the First Session of the Twenty-Third Congress: March 4, 1789 to June 15, 1834 (Duff Green: Washington, 1834), 467-8.
} 
venison, bear's meat, wild turkeys, and other game." ${ }^{502}$ Two years later, a "party of thirty Delawares with their squaws and pappooses" visited Henry II as they passed through Nazareth on their way to Philadelphia. Gelelemind returned to Ohio in 1798, along with David Zeisberger and several other Christian Indians, to establish the mission town of Goshen. William Henry's brother Matthew met with Gelelemind and three of his sons - John Henry, Charles, and Christian Gottlieb - as he traveled through Ohio in 1800. According to Matthew, Charles was "married to a white woman, who was taken prisoner when a child" and "knows nothing of her parentage or native language." Another son, Christian, "whose wife is at Fairfield in Canada" served as Henry's guide. ${ }^{503}$

In 1805, Gelelemind petitioned Pennsylvania's governor to grant him rights to Killbuck Island, outside of Pittsburgh. He cited the fact that he had "uniformly maintained peace and friendship" with the Americans, which resulted in his life being threatened from "those Indians who had joined the English." 504 At the same time, he had missionary John Mortimer compose a letter to William Henry II, who was now a judge in Pennsylvania. Gelelemind addressed the letter to "My dearly beloved William Henry," and opened the missive "as you have the same name with me, and I have often heard of your love for me and my family, therefore I send this letter to salute you all, from me and my children, and grandchildren, and to assure you of our love for you." He continued, "My dearly beloved brethren: We are truly poor, needy and undeserving people; think with compassion on us. It is my desire to live entirely for our Saviour, and place my whole confidence in him. That is all I have to say to you." ${ }^{505}$

\footnotetext{
502 Jordon, 12.

503 Jordan, 14-15.

${ }^{504}$ William Henry Killbuck to Gov. Thomas McKean, January 8, 1805 in The Pennsylvania Magazine of History and Biography 10, no. 1 (1886), 117.

505 Jordon, 15.
} 
This odd letter appears to be the last communication between Gelelemind and the Henry family. Gelelemind may have hoped that Henry would intervene on his behalf to support his petition for Killbuck Island, but if so the request remained unspoken. There is no evidence that Henry responded to Gelelemind's letter, let alone offered his assistance. Nonetheless, on March 28, 1811, the Pennsylvania Legislature finally approved an act to "compensate William Henry Killbuck [Gelelemind], a chief of the Delaware tribe of Indians" for services provided to the Americans during the Revolution. A "sum of forty dollars" was to be paid "immediately" and a "further sum of forty dollars annually during life." They also called for three rifles, worth sixty dollars, be given to "the sons of William Henry Killbuck... as an acknowledgement of the services rendered by their father." 506 The gesture came too late to benefit the former warrior. Gelelemind had died on February 17, 1811. Before he passed, Gelelemind advised his sons "never to aim to become chiefs or headmen." ${ }^{507}$ He was buried alongside David Zeisberger in the Goshen Mission Cemetery in Ohio. In 1873, more than a century after William Henry and Gelelemind first met, John Henry Killbuck, Gelelemind's great-grandson, attended the Moravian Institute for Boys in Nazareth and then enrolled at Moravian College in Bethlehem. Following his graduation, he married "a white woman of excellent parentage" and became a missionary for the Moravian Church. ${ }^{508}$

The Seven Years' War was a turning point for the Moravian missions in Pennsylvania and the Ohio Country, but the Revolutionary War proved to be the undoing of the MoravianDelaware political and spiritual alliance. Despite Ettwein's successful efforts to secure lands

\footnotetext{
${ }^{506}$ Journal of the Twenty-First House of Representatives of the Commonwealth of Pennsylvania, 235-6, 742, in Gordon, "Killbuck-Henry Legend Part 2," 8.

${ }^{507}$ Goshen Diary, February 19, 1811, Moravian Archives Bethlehem, PA, quoted in Gordon, "Killbuck-Henry Family Legend Part 2," 8.

${ }^{508}$ Jordon, 16-8. In 1892, Edith Killbuck, John Henry's wife, visited James Henry in Pennsylvania. She and her husband were still in Alaska, working on behalf of the Moravian church.
} 
formally recognized by the United States government - and thus reasonably safe from white settlers - the Moravians were never able to reestablish a thriving mission community in the Ohio region. The missions in the Ohio Country withered as the result of racialized violence against Native Americans and the Moravians' own alienation from the white community during the American Revolution. In the early years of the Revolutionary War, Moravian leaders were able to rely on their political connections to shield their towns and congregants from persecution. But as the war progressed, a radical new democracy in the west undermined the authority of eastern leaders and rendered them powerless to control white settlers who enforced their own vision of justice against Native peoples.

The Gnadenhütten Massacre highlighted the limits of eastern authority in the west. Although state and federal officials denounced the event and demanded an investigation, Williamson's men were never held accountable for their actions. Not by American authorities, in any case. Shortly after the Gnadenhütten Massacre, members of Williamson's militia reassembled under William Crawford and launched an expedition against the Delaware and Wyandot near Sandusky. The ill-fated march ended in chaos and Crawford, along with several others, was captured by Delaware warriors. Well aware of the events that had transpired in Gnadenhütten, the Indians "were very much enraged against the prisoners, particularly Captain Pipe one of the chiefs." ${ }^{509}$ Crawford's grisly death came only after hours of torture. The men who actually killed unarmed Delaware at Gnadenhütten, for the most part, avoided capture and escaped unscathed.

For Native peoples, the Gnadenhütten Massacre offered horrific proof that the Moravians did not have the political clout necessary to protect the Delaware or their land from attack. It is

\footnotetext{
${ }^{509}$ H.H. Brackenridge, ed. Narratives of a Late Expedition Against the Indians: With An Account of the Barbarous Execution of Colonel Crawford and the Wonderful Escape of Dr. Knight and John Slover from Captivity in 1782 (Philadelphia: Francis Bailey, 1783), 5-10.
} 
worth noting, however, that the Brethren used every avenue at their disposal to protect the Moravian Indians during and after the war. General Hand's conciliatory response to David Zeisberger's letters in 1777 was no doubt influenced by his promise to William Henry that he would "help and serve the Brethren" in the Ohio Valley " in every way he can." 510 The commanders at Fort Pitt - first Captain Brodhead and later William Irvine - did intervene on behalf of the Moravians repeatedly. During the Indian wars of the 1780s, when Christian Indians received "terrifying Reports of the determined resistance of the white People on the Ohio, against their Return to their old Towns," the Moravians petitioned "the Brittish Government for Leave to come to the East Side of Lake Erie and to lend them some Land, where they could plant and live on until Peace should be restored." Fearing for their lives at the hands of the Americans, the missionaries "saw no other way to keep their Flock together" than to "retire under the Brittish Government" in Canada, where "some Land...was lent them and Protection promised." 511

While the Indians sheltered in Canada, Ettwein continued his efforts to secure a permanent, recognized territory for them in Ohio. The end result was certainly less than Netawatwees and the leaders who invited the Moravians to the Ohio Country would have hoped. Twelve thousand acres under the control of the Society for the Propagation of the Gospel Among the Heathen by no means constituted the type of Delaware homeland Indian leaders envisioned. But the failure was neither the result of the Indians' misjudgment in cultivating an alliance with the Moravian church nor the Brethren's unwillingness to use their political connections for the benefit of their Indian friends. The dramatic upheaval of the American Revolution fundamentally reshaped the political landscape and rendered the Moravian-Delaware alliance futile. The Society

\footnotetext{
${ }^{510}$ Letters from Lancaster to Provincial Helpers Council, 1754-1790, Moravian Archives Bethlehem, PA, quoted in Gordon, "William Henry of Lancaster and Mixed Living," 32.

511 John Ettwein to Thomas Jefferson, November 19, 1791. Founders Online, National Archives, https://founders.archives.gov/documents/Jefferson/01-22-02-0286.
} 
for the Propagation of the Gospel Among the Heathen returned the twelve thousand acres to Congress after the last remnants of the Ohio Indian missions folded in 1821.512

${ }^{512}$ Engel, 239. 


\section{Epilogue \\ Triumph in Death: The Ohio Missions in Public Memory}

On September 3, 1783, the Treaty of Paris ended the Revolutionary War. As Americans celebrated their new nation, David Zeisberger and his Native converts struggled to carve a place for themselves in an uncertain new world. Although the last Moravian mission in Ohio did not fold until 1821, the Gnadenhütten Massacre signaled the downfall of the Moravian-Indian political and spiritual alliance in the Ohio Country. Despite their relatively short life-span, the Moravian missions became an integral part of the state's founding narrative. Beginning in the mid-nineteenth century, local activists rallied to commemorate the victims of the Gnadenhütten Massacre. By the mid-twentieth century, Gnadenhütten and Schoenbrunn were well-established historic sites drawing tourists from across the United States. As the Moravians were embedded in local mythology, the public came to remember them as Ohio's first pioneers. The complicated relationships between Moravians, Native peoples, and imperial powers gave way to a simple narrative that celebrated a distinctly white, Christian version of history.

After Williamson's men left the smoldering remains of Gnadenhütten and its former residents, the site was abandoned for over a decade. In 1797, members of the Moravian church finally returned to the former mission town. Upon their arrival, they gathered together what scattered human remains they could find and buried them in a single mound. It wasn't until 1843, years after the Moravians had ended missionary efforts in the region, that the Gnadenhütten Monument Society formed and declared it their mission to "perpetuate the memory of the ninetysix Christian Indians" who "fell innocent victims to the savage ferocity of the lawless band of whites." 513 The Society acquired roughly six acres of land, which included the original mission town and the surrounding fields, and set about clearing "the underbrush with which it was

${ }^{513}$ Gnadenhütten Monument Society, A True History of the Massacre of Ninety-Six Christian Indians, at Gnadenhütten, Ohio, March 8, 1782 (New Philadelphia: Printed at the Ohio Democrat Office, 1870), 12. 
overgrown" and fenced in the area where "the slaughter houses can still be identified." The Monument Society functioned largely as a fundraising organization. Their goal was "the erection of a suitable monument on the spot where the massacre was perpetrated." 514

It took nearly thirty years, but in the summer of 1872 the Monument Society unveiled their memorial to some "ten thousand citizens of the Tuscarawas valley." 515 Reverend Edmund De Schweinitz, the Moravian bishop and historian, "delivered an oration of rich historic interest and rare beauty of expression" and "an immense band of trained singers" entertained the assembled crowd. ${ }^{516}$ The highlight of the event, however, was the moment when "four Indians of the Delaware tribe, two of them lineal descendants of the massacred Indians," pulled away a canvas to reveal the thirty-five foot gray stone obelisk. ${ }^{517}$ The simple structure bore the inscription "Here Triumphed in Death Ninety Christian Indians, March 8, 1782." The Indians who attended the ceremony traveled from Canada with "their missionary, the Rev. Mr. Riennecke," and the Moravian church sent a number of representatives from Bethlehem. ${ }^{518}$ Most of the observers arrived from the surrounding counties, according to local historian William Hunt, demonstrating "the interest of the whole people of the Tuscarawas valley," especially "those of classic and Christian taste and feeling" and "all interested in the annals of heroism and the legends of the Christian faith."519 The centennial commemoration of the massacre drew similar crowds. One estimate placed the gathering at "nearly 10,000 people," many of whom

\footnotetext{
514 Ibid.

515 William Ellis Hunt, Historical Collections of Coshocton County, Ohio: A Complete Panorama of the County, From the Time of the Earliest Known Occupants of the Territory Until the Present Time (Cincinnati: Robert Clarke \& Co. Printers, 1876), 170.

516 Ibid.

517 Ibid.

${ }^{518}$ Ibid. Following the violence in Gnadenhütten, some Christian Delaware and Moravian missionaries fled north, eventually creating the Fairfield settlement town in what is today southwestern Ontario. Many Christian Delaware continue to live in Moraviantown - according to the Delaware Nation at Moraviantown website, "there are about 574 residents of Moraviantown, with more than 1100 registered members who live throughout Ontario, Canada and the world." See http://delawarenation.on.ca/about-us.html for more information about Moraviantown.

${ }^{519}$ Hunt, 171.
} 
traveled to Gnadenhütten on "excursion trains" routed specifically for the event. Charles Foster, then governor of Ohio, and several "other distinguished guests" spoke at the anniversary event. $^{520}$

The Gnadenhütten Massacre continues to draw attention. In 2003, an Ohio Historical Marker sponsored by the Ohio Bicentennial Commission, the Society of Colonial Wars in the State of Ohio, and the Ohio Historical Society was placed at the site of the massacre. One side of the marker provides a brief overview of the mission towns; the other side, entitled "The Gnadenhütten Massacre: A Day of Shame," outlines the events of March 8, 1782. According to the marker, the Gnadenhütten Indians were "mistaken for Indian raiders who had struck in western Pennsylvania a few weeks earlier" and were subsequently "captured without incident and sentenced to death by a group of Pennsylvania militia seeking revenge." It concludes that the "massacre did not ease hostilities in western Pennsylvania, but fueled more attacks by Wyandot, Delaware, and Shawnee Indians." ${ }^{521}$ On March 8, 2017, the $235^{\text {th }}$ anniversary of the murders was commemorated with a ceremony at the site. According to the Columbus Monthly, a group of local residents and pastors "met at the burial mound to acknowledge the memory of the Moravian Delaware Martyrs." 522 Gerard Heath, whose "great-great-grandfather, Christian Moses Stonefish" participated in the 1872 dedication ceremony, shared his wish to "raise funds to erect a Christian Cross at the burial mound." In addition to the cross, the Gnadenhütten Historical Society plans to add wrought-iron fencing around both the burial mound and the massacre site.

\footnotetext{
${ }^{520}$ Henry Howe, Historical Collections of Ohio: An Encyclopedia of the State; History Both General and Local, Geography, Sketches of Eminent and Interesting Characters, etc. with Notes of a Tour Over It In 1886, Vol. 3 (Columbus: Henry Howe \& Son, 1891), 371.

521 "Gnadenhütten.” The Ohio History Connection Historic Marker Database, Remarkable Ohio, http://www.remarkableohio.org/index.php?/category/1428.

${ }_{522}$ Cindy Davis, "Event Marks Massacre of Moravian Delaware Indians in Gnadenhütten," Columbus Monthly, March 12, 2017, http://www.columbusmonthly.com/news/20170312/event-marks-massacre-of-moravian-delawareindians-in-gnaden
} 
The Gnadenhütten massacre was by no means the first time that Native peoples were targeted because of their race and it was far from the last. There are a number of historic sites throughout the United States dedicated to such atrocities. But commemoration efforts at Gnadenhütten are unique for their portrayal of the victims as Christian martyrs who "triumphed in death." This is a perplexing interpretation of events and one that has not been applied to other victims - Indians or white - who suffered such violence. When the massacre took place in 1782 , contemporaries understood that the Indians had been targeted because of their race. By the nineteenth century, however, the Gnadenhütten Indians were remembered as martyrs for their faith. Williamson's men sought revenge on Indians, but the victims are remembered as Christians.

The recasting of the Gnadenhütten Massacre to focus primarily on religion irrevocably alters how public audiences understand the events of March 8, 1782. A history of early Ohio published in 1871 referred "to the graves of the Indian martyrs, who fell victims to that love of peace which is the genuine attribute of Christianity." 523 This interpretation ignores the fact that many non-Christian Delaware also sought to remain neutral in the conflict and worked to maintain peaceful relations between Indian peoples and Euro-Americans. It may be true that the Indians' religious beliefs shaped how they responded to their impending death. By all accounts, the Indians spent their last hours praying and singing; they made no attempt to violently resist Williamson's men. But it was not the "love of peace" that led to their death. The fact that they were Christian was irrelevant to the militia men who murdered them. Some of Williamson's men did not believe the Indians' professions of faith; some simply did not care. When the Indians welcomed the militia, accompanied them back to Gnadenhütten, and handed over their weapons, they did not do so because of their pacifist ideals - they did so because they believed that the

\footnotetext{
${ }^{523}$ Howe, 371.
} 
Americans were allies prepared to relocate the Moravian Indians to the relative safety of Fort Pitt.

The suggestion that the Gnadenhütten Massacre resulted from the Indians' religion creates a confusing narrative that fails to explain why the militia elected to kill ninety-six men, women, and children. It does offer a reason for why future generations of Ohio citizens chose to celebrate these particular Indians, however. When the Gnadenhütten Monument Society formed in 1843, it argued that the Indians' "meek endurance of suffering, crowned with triumphant death, is worthy of commemoration." 524 In nineteenth-century America, the Moravian Indians somber and peace-loving - were sympathetic figures in a way that Native peoples more broadly were not. Because they had accepted many of the teachings and trappings of the white world, their deaths constituted a tragedy while the deaths of other Indian men, women, and children were overlooked. By coupling the Moravians' murder with their religion, the Gnadenhütten Monument Society erased the reality that the Christians' fate was linked to that of other Native peoples in the Ohio Country. This narrative holds Williamson's men responsible for the violence at Gnadenhütten but fails to acknowledge the social and political context that encouraged such atrocities. In the late eighteenth century, hatred of Native peoples and lust for their lands led to a series of violent encounters that eventually pushed Indians westward and opened Ohio for widespread settlement. The insistence that the Moravian Indians received a heavenly reward for their suffering eased the collective guilt of those who directly benefitted from Native peoples' dispossession.

If the Gnadenhütten Massacre garnered attention because its victims were viewed as Christian martyrs, the Moravian missions were deemed worthy of recognition for establishing a

\footnotetext{
${ }^{524}$ Gnadenhütten Monument Society, A True History of the Massacre of Ninety-Six Christian Indians, at Gnadenhütten, Ohio, March 8, 1782 (New Philadelphia: Printed at the Ohio Democrat Office, 1870 ), 12.
} 
white presence in the Ohio Country. Several early histories of the region claimed John Heckewelder's daughter, Johanna Maria Heckewelder, was "the first white child who saw the light of Heaven in Ohio," a claim that made her "the object of unusual attentions" as "visitors from all parts of the country resorted to her residence...Historians sought her acquaintance, antiquarians her photograph and autograph; learned societies her correspondence." ${ }^{525}$ In 1846, a local historian challenged Heckewelder's title, pointing to a passage in Edmund De Schweinitz's "Life of David Zeisberger" that noted Zeisberger had baptized John Lewis Roth, the son of two Moravian missionaries, in Gnadenhütten during the summer of 1773 - eight years before Heckewelder's birth in 1781. In 1871, the Western Reserve Historical Society published an article that carefully examined the possibility that a white child had been born in the area that became Ohio prior to the establishment of the Moravian missions and concluded that although "white children were doubtless born to some of the many traders in Ohio before $1763 \ldots$ there is no evidence that such was the fact." ${ }^{526}$

As there was no conclusive evidence to prove that John Roth was not the first child born in Ohio, Gnadenhütten's organizers staked their claim. Today, visitors on their way to view the Gnadenhütten monument walk past a marker recognizing the "Birthplace of First White Child Born in Ohio." The sign is planted beside a plaque that reads "This tablet marks the birthplace of the first white child born in the Moravian mission house at Gnadenhütten, John Lewis Roth.” The Ohio Society Daughters of the American Colonists erected the memorial in 1934, sixty years after the unveiling of the monument to the massacre victims, positioning it directly beside the reconstructed cooper's house where the executions took place. The presence of a marker commemorating the birth of the "first white child" in the shadow of a monument

\footnotetext{
${ }^{525}$ Alfred. T. Goodman, "First White Child in Ohio," Western Reserve and Northern Ohio Historical Society, no. 4 (Cleveland: Western Reserve Historical Society, 1871).

526 Ibid., 1.
} 
commemorating the murder of Native peoples is jarring. Perhaps unintentionally, the juxtaposition reinforces a narrative of inevitable American expansion at the expense of the “disappearing Indians."

The Gnadenhütten historic site revolves almost exclusively around the massacre, but a short drive away, Schoenbrunn Village offers visitors a glimpse of everyday life in the mission settlements. Schoenbrunn, founded on May 3, 1772, was the first village that the Moravians established in the Ohio Country. It was abandoned five years later, when residents fled to Lichtenau. Before leaving, Zeisberger set fire to the church; the rest of the town burned soon thereafter. In the years following the Revolution, Native peoples were forced westward and American settlers slowly transformed the forests into farms. The remnants of Schoenbrunn disappeared beneath plowed fields and the town faded from memory. Over a century later, a Moravian minister in nearby Dover, Ohio, began searching for the mission town and associated burial ground. Working from the mission diaries, Reverend J.E. Weinland eventually pinpointed the location of the burned village. In 1923, excavations of the area uncovered the charred remains of Schoenbrunn and forty-five skeletons in "God's Acre," the settlement's cemetery. ${ }^{527}$ Following the discovery, the Tuscarawas County Historical Society and the Ohio State Archeological and Historical Society appointed a local commission to "have charge of the site and of the securing of a fitting Memorial." 528 Weinland served as chair of the committee, which included the mayor of New Philadelphia as well as a member of the local chamber of commerce and the superintendent of the local school system. ${ }^{529}$ The Schoenbrunn committee launched a fundraising campaign aimed at rebuilding part of the town and opening the site to the public.

\footnotetext{
${ }^{527}$ Jim Baker, “Ohio Was Like That," The Columbus Sunday Dispatch, July 25, 1948, Moravian Archives Bethlehem, PA.

528 “The Romantic Story of Schoenbrunn," Pamphlet, unknown publication date, Moravian Archives Bethlehem, PA.

${ }^{529}$ Ibid.
} 
They focused their efforts on churches throughout the state, distributing pamphlets detailing the "Romantic Story of Schoenbrunn" and requesting that each church in Tuscarawas County donate "10c per member" and suggesting "1c per member from the churches throughout the rest of the State." Weinland urged congregations to consider "the heroic labors of these pioneer heralds of the gospel and their converts" and argued that the memorial was "not a local matter, nor does it concern only the state, but it should be a matter of interest to everyone now living in the great North West Territory." 530

In order to convince Ohio residents that the former mission town was worthy of their attention (and money), Weinland and the Schoenbrunn Committee emphasized a history that was both Protestant and white. They distributed pledge cards that encouraged recipients to give "an offering towards rebuilding the first Protestant Church in Ohio," and proclaimed Schoenbrunn "the first town in Ohio." 531 The missionaries were "pioneer heralds of the Gospel" and the town represented the spot where "the first ground was broken for the cultivation of crops according to civilized methods." ${ }^{532}$ This tactic was successful. In 1926, Dr. W.J. Holland, the director of the Carnegie Museum in Pittsburgh, Pennsylvania, praised Weinland's efforts to rebuild the mission town. "The plan to erect a proper memorial," Holland wrote, "should have the hearty support and approval of all those who are interested in preserving the records of our historic past." Holland promised "to do anything in my power" to help move the project forward, citing his belief that "if the people of New England remember Plymouth rock, the people of Ohio and the states west should do something to mark the labors and sacrifices of the heroic men who laid the foundations Schoenbrunn." Their work, in Holland's mind, was "in as noble a spirit as what was

\footnotetext{
530 J.E. Weinland to Ohio Churches, date unknown, Moravian Archives Bethlehem, PA.

531 "The Romantic Story of Schoenbrunn" and "An Offering," Moravian Archives Bethlehem, PA.

${ }^{532}$ W.J. Holland to J.E. Weinland, December 8, 1926, Moravian Archives Bethlehem, PA.
} 
accomplished by the founders of New England" and it was "time that the world should not only hear of what was done, but preserve memorials of what was done." 533

The recreated Schoenbrunn reflected this vision of the Moravians as civilizing pioneers. The first building to be erected was a replica of the mission schoolhouse, followed by the church. A dedication ceremony for the schoolhouse took place on July 29, 1928, one hundred and fiftyfive years to the day after the original had been completed. Schoenbrunn's school was remembered as the "first school house in Ohio" while David Zeisberger received recognition as “Ohio's First School Teacher." The program for the day included hymns, a trombone concert, addresses by the Lieutenant Governor of Ohio and the State Director of Education, and the presentation of an American flag by the Daughters of Union Veterans. ${ }^{534}$ Four months later, a similar ceremony marked the first service in the rebuilt church.

National trends soon helped establish Schoenbrunn as a tourist destination. During the 1920s, the National Park Service had launched their "See America First" campaign, which aimed to persuade upper-middle-class white Americans to forgo travel in Europe in favor of exploring their own country. Originally, the NPS partnered with railroad companies to promote destinations such as Glacier and Yellowstone National Parks and the Grand Canyon. As more Americans purchased cars and highway systems expanded, automobile tourism gained popularity and slowly replaced travel by rail. In 1926, the Tuscarawas County Automobile Club seized on this shift and published promotional materials urging tourists to explore "the Cleveland-MariettaFlorida Federal Route Midway Between The Lincoln and National Highways.” One pamphlet described Tuscarawas County as the place "Where Alluring Beauty is woven with Early Ohio

\footnotetext{
533 Ibid.

534 "Dedication of the Replica of the First School House in Ohio," July 29, 1928, Moravian Archives Bethlehem, PA.
} 
History;" a hand drawn map highlighted "Historic Sites, Scenic Drives, Paved Roads" which included Schoenbrunn and Gnadenhütten alongside sites such as Fort Laurens. ${ }^{535}$

The growth of national tourism in the first decades of the twentieth century promoted "an idealized American history" that "linked national identity to a shared territory and history" and advocated "tourism as a ritual of American citizenship." ${ }^{536}$ Tourism dwindled during the Great Depression, but federal New Deal projects bolstered the Schoenbrunn historic site. In the 1930s, the Ohio State Archeological and Historical Society partnered with the National Park Service and Civilian Conservation Corps to build additional structures in the village. In keeping with a historical narrative that elevated the stories of white Americans over Native peoples, CCC workers recreated the Richard and Peggy Conner Cabin, which opened to public fanfare on May $12,1935.537$

While members of the CCC erected log houses in Schoenbrunn, those employed by the Federal Writers' Project explored the region and mapped out a series of driving tours that were eventually published in The WPA Guide to Ohio: The Buckeye State. The Works Project Administration's guide mapped driving tours than included both Schoenbrunn Memorial State Park and the Gnadenhütten massacre monument. ${ }^{538}$ Schoenbrunn continued to expand over time, and by 1948 the reconstructed town included twelve cabins in addition to the school and church buildings. ${ }^{539}$ As the United States prepared for its approaching bicentennial celebration in the early 1970s, Schoenbrunn once again received a flurry of attention from state and local governments. The Ohio Historical Society funded college students to Schoenbrunn Village create

535 "Where Alluring Beauty is Woven with Early Ohio History," Tuscarawas County Automobile Club, 1926, Moravian Archives Bethlehem, PA.

${ }^{536}$ Marguerite S. Shaffer, See America First: Tourism and National Identity, 1880-1940 (Washington: Smithsonian Institution Press, 2001), 4.

537 "Dedication of the Conner Cabin," May 12, 1935, Moravian Archives Bethlehem, PA.

538 The Ohio Guide, Writers' Program of the Works Projects Administration in the State of Ohio (New York: Oxford University Press, 1940).

539 “Ohio Was Like That” Columbus Sunday Dispatch, July 25, 1948, Moravian Archives Bethlehem, PA. 
a series of programs depicting life in "Ohio's first organized settlement." Visitors could participate in candle dipping and cooking demonstrations, walk along gardens teeming with the traditional Indian crops of corn, beans, and squash, and watch artisans create pipe stems. Village cabins were renovated and decorated with "furnishings of the type originally used" at the settlement. ${ }^{540}$

Schoenbrunn Village continues to draw visitors and school groups by promoting itself as the "site of several Ohio firsts - settlement, church, schoolhouse and code of law." ${ }^{541}$ David Zeisberger would no doubt be chagrined to discover that this is his public legacy in Ohio. That the Moravians moved westward in hopes of eliminating "white influence" on their Native converts has been long forgotten; instead, they are celebrated for bringing civilization to the wilderness. This theme is also present in the county's largest tourist attraction - an outdoor drama about Zeisberger and his doomed missions. In 1970, Trumpet in the Land premiered at the Schoenbrunn Amphitheatre in New Philadelphia, Ohio. It has returned each summer for the past forty-seven years. Promotional materials for the play invite visitors to "watch the warm summer nights come alive with beautiful horses, brilliant fire dances, authentic looking costumes, fiery battle pyrotechnics, and a beautiful natural stage." 542

Trumpet in the Land was written by Paul Green, a University of North Carolina professor known for his Pulitzer-prize winning drama In Abraham's Bosom. Green was born in Harnett County, North Carolina, in the spring of 1894. As a young man, his commitment to working toward racial equality put him out of step with many of his peers. Nonetheless, Green devoted himself to securing "basic human rights for blacks and Native Americans" and throughout his

\footnotetext{
540 “What's Going On,” History News, 26 no. 10 (October 1971): 230-2.

541 "Schoenbrunn Village," Ohio History Connection, https://www.ohiohistory.org/visit/museum-and-sitelocator/schoenbrunn-village.

542 "Paul Green's Trumpet in the Land: Ohio's First and Finest Outdoor Drama," program from play, Summer 2014.
} 
long career focused on bringing untold stories of America's minority populations to the public. ${ }^{543}$ Although Green was white, he sought to bring an "authentic black experience into drama" with his early works. ${ }^{544}$ In addition to his most famous play, In Abraham's Bosom, he produced the script for Richard Wright's Native Son and John Howard Griffin's Black Like Me. During the 1930s, Green created what became his signature style of theater: the symphonic outdoor drama. His first attempt in 1934, Roll Sweet Chariot, received a lukewarm response, but 1937's The Lost Colony proved a smashing success. The play continues to draw huge crowds to Manteo, North Carolina, each summer.

Green's Trumpet in the Land debuted as the United States approached its bicentennial, but it may have been the Vietnam War rather than the approaching anniversary that prompted Green to pen the play. Green was an early opponent of American involvement in Vietnam and struggled to make a "statement of man's dilemma of war and peace." ${ }^{545} \mathrm{He}$ considered himself a "man of peace" but remained conflicted about pacifism as a practice. The story of the Moravians in Ohio during the Revolutionary War offered a platform upon which to publically explore his inner turmoil. In a 1975 letter, Green acknowledged that while he had "written several plays on the subject of peace - Wilderness Road, Trumpet in the Land, Cross and Sword - and I have yet to dispense with force, armed might, when ideals are threatened to death." 546 He returned to the topic in a letter the following year, noting "in Trumpet in the Land my Moravian hero refuses the gun, but many of his innocent followers die because he does." 547

\footnotetext{
543 Ibid., xxii.

${ }^{544}$ Laurence G. Avery, ed. A Southern Life: Letters of Paul Green, 1916-1981 (Chapel Hill: The University of North Carolina Press, 1994), xx.

545 Paul Green to Cheryl Crawford, April 22, 1975, in Avery, ed. A Southern Life, 680.

${ }^{546}$ Ibid., 681.

${ }^{547}$ Paul Green to Maxim Tabory, April 12, 1976, in Avery, ed. A Southern Life, 689.
} 
Given Green's oeuvre and interest in issues of race in America, one might expect Trumpet in the Land to offer a nuanced portrayal of the missionaries and Natives struggling to navigate the increasingly dangerous Ohio borderlands. His research files included materials from Moravian mission diaries and an overview of David Zeisberger's life, along with early histories of Ohio. Yet Green's narrative tumbles into stereotypical portrayals of Native peoples and celebrates the eventual settlement of the Ohio Country. One major plotline follows the unfolding of events in the Moravian mission towns as the American Revolution progresses; the second involves Zeisberger as an eligible bachelor relentlessly pursued by a determined Susan Lecron, who eventually succeeds in becoming his wife. Isaac Glikhickan, Israel Welapachtschiechen, and Gelelemind all make brief appearances under their baptismal names but there is no suggestion of the role that these men played in the Native community. White Eyes is responsible for inviting the Moravian missionaries to the region, while Captain Pipe leads the factions opposed to the Moravian presence in the Muskingum Valley.

It is unreasonable to expect the political complexity of the eighteenth-century Ohio Country to be thoroughly explored in a ninety-minute theater production. However, Trumpet in the Land offers only the most simplistic explanation for the events that transpired during the Revolutionary era. As the lights go down, a narrator addresses the audience "Friends, we are here this evening to pay honor to those men and women who some two hundred years ago came into this valley and built here the first settlement in Ohio." 548 As this introduction suggests, the missionaries and their Native supporters are the clear protagonists - reasonable and civilized while those who object to their presence hover on the edge of savageness. The program describes Captain Pipe as "a young warrior chief whose hatred of all white men for killing his father added

\footnotetext{
${ }^{548}$ Paul Green, Trumpet in the Land, production script, from University of North Carolina Southern Historical Collection, Paul Green Papers, 1880-1992, folder 3493, 1. http://finding-aids.lib.unc.edu/03693/\#folder 3493\#1.
} 
to the dangers facing the missionaries." Simon Girty, a former white captive adopted by the Seneca and a staunch British ally, is "a conniving renegade who agitated for all-out war in the region." $" 549$

In an early scene, the Delaware Grand Council eagerly awaits the Moravians' arrival. When one leader notes that "Our council member, Chief Captain Pipe comes not," White Eyes responds "He still growls in the forest...but he will see, he will see, the way of the teacher is good." ${ }^{50}$ When Pipe arrives on stage, he accuses White Eyes of giving away "our homeland" and warns the assembled Indians "Where the white man comes, the Indian dies." Pointing to the disheveled Indian "witchwoman" beside him, Pipe shouts "See what the white men have done to her! Her husband murdered, her baby slain...the Great Spirit has set her to guard this Tuscarawas Valley." Turning to the Moravians, he hisses "Her curse is upon you if you come here. You have great warning from her. Leave our land." ${ }^{551}$ Green's production notes describe the "witchwoman" as "a strange eldritch character" who is "tall, emaciated, with long stringy hair and a face chalk-white... set with two vindictive roving wild black eyes." 552 The scene is not entirely unsympathetic to Pipe and the Delaware woman - the audience understands that they have both suffered at the hands of white men - and yet they are wild, irrational creatures bent on attacking the Moravians who seek only to "make a better home for all." 553

Pipe may be given some motive for his actions, but Simon Girty is an unrepentant scoundrel who appears to thrive on causing trouble and persuading neutral Delaware to join in the war. He boasts to the missionaries 'I'm beating the drum for his majesty's volunteers to go to

\footnotetext{
549 "Paul Green's Trumpet in the Land: Ohio's First and Finest Outdoor Drama," program from play, Summer 2014.

${ }^{550}$ Paul Green, Trumpet in the Land, production script, from University of North Carolina Southern Historical Collection, Paul Green Papers, 1880-1992, folder 3493, 2.

${ }^{551}$ Ibid., 5 .

552 Ibid.

${ }^{553}$ Ibid.
} 
Detroit - like my friends here." Girty's Indian friends crowd around him as he adds “And speaking of salvation, I'm giving it out free - good old rum!" Green's production notes direct the Indians to "crowd up around with grunts and licking of lips" as Zeisberger scolds "A shameful thing, Simon Girty, to so debauch these trusting people!" ${ }^{554}$ Simon grins and declares "Why, Preacher, there's more salvation in cupful of this rum than in a dozen of your sermons.

Try it, and...in a week you'd have more Delaware converts at Schoenbrunn then you could shake a stick at!" 555 This scene is representative of how British-allied Indians are portrayed throughout the play - a sharp contrast to both the pious Moravian Indians and the somber American-allied White Eyes.

While Pipe and Girty harass the Moravians from one side, an American militia looms threateningly on the other. Green divides the Americans into two factions. One, represented by the violent Colonel Williamson, is characterized by their distrust and dislike of Native peoples. Williamson denounces "the treachery of them so-called Christian Indians" and makes clear his contempt for Native peoples at every opportunity. The America Williamson seeks to build is one characterized by "bridges, ships and ploughs and machines - work, build, power, power!" and he declares his intention to "kill and cut and burn and destroy anything that tries to stop me. And there are plenty like me - true Americans!" 556 In contrast to Williamson, an earnest young soldier named Ben fights to bring about a new nation where "all men are created equal." Ben is in love with Esther, a young Moravian Indian, and believes that "Preacher Zeisberger's flock...are good people if ever I saw any.” Ben represents an idyllic American nation, one not obsessed with power but composed of wholesome farmers living peacefully alongside their Indian neighbors. Ben's vision of the future welcomes Native peoples as equals, but he also

\footnotetext{
${ }^{554}$ Ibid., 33.

${ }^{555}$ Ibid., 34.

${ }^{556}$ Ibid., 84.
} 
declares “Soon's this war's over, I'm making for my land on the Ohio River. And I'm going to settle down there." ${ }^{557}$ The inherent tension between these two desires - to maintain friendly relations with the Indians and to acquire their land - is never addressed.

The penultimate scene in Trumpet in the Land is the Gnadenhütten Massacre. Green frames the event as a quest for revenge from the moment that Williamson marched his men into Ohio. The expedition begins after a distraught man stumbles into the Americans' camp and begs Williamson to pursue the warriors responsible for killing his family. The murder is described in all of its gory detail, "Bloodier than a hog-killing! And the baby with its brains running down its face was stuck on a stake in garden for the crows to peck at!" ${ }^{558}$ Williamson and his men gather to pray, then march off stage as the narrator's voice informs the audience that these men "cunningly disarmed" the trusting "brown brethren" and "made them prisoners." Isaac Glikhickan offers himself but asks Williamson to spare the women and children, to which Williamson replies "You all are Indians - all are guilty." ${ }^{559}$ Isaac then raises his hands and declares "If we are to perish, then let it be without fear or hate in our hearts...Let it be said that here at Gnadenhütten, the place of our sacrifice, we forgive, and so we shall triumph in our death." 560

The play draws to a close as the Moravian missionaries and the remaining Christian Indians return to Gnadenhütten to mourn the dead. Ben is there, along with a few other militia men who were conveniently absent when the massacre took place and are horrified by the violence. Zeisberger addresses the small group

With the war now ended this new nation begins, founded on the faith in which we all believe - peace and brotherhood,

\footnotetext{
557 Ibid., 83.

558 Ibid., 86.

559 Ibid., 90.

560 Ibid.
} 
and let us hope that this new nation will never again resort to war and that men like Colonel Williamson will never again control her armies. You, Ben Campbell and Esther...go to your land on the Ohio River and help build this nation. Remember those who have perished here at Gnadenhütten. ${ }^{561}$

Ben and Esther leave hand in hand, presumably to build their homestead in Indian country; Zeisberger and Heckewelder vow to build "a new Schoenbrunn," the music swells, and the lights go up. Green's drama ends on a hopeful, if bittersweet, note - one that audiences have been responding to for decades. In spite of tragedy, the Moravians press forward with their mission. Ben and Esther set about their task of creating a new home in the wilderness, and in the process, of building a new nation. Absent from this promising future are Ohio's Native peoples. Pipe and the British-allied Indians retreat; White Eyes and the American-allied Delaware simply fade from the storyline. The Christian Indians may have triumphed in death, but they are now merely a memory of a world that used to be.

${ }^{561}$ Ibid., 100. 


\title{
BIBLIOGRAPHY
}

\author{
ARCHIVAL COLLECTIONS \\ Moravian Archives, Bethlehem, Pennsylvania \\ August Gottlieb Spangenberg Papers \\ John Ettwein Papers \\ Joseph E. Weinland Papers \\ Records of the Indian Missions, 1742-1898
}

American Philosophical Society, Philadelphia, Pennsylvania

Timothy Horsfield Papers

Historical Society of Pennsylvania, Philadelphia, Pennsylvania

Timothy Horsfield Letterbook

Newberry Library, Chicago, Illinois

Edward E. Ayer Collection

University of North Carolina Southern Historical Collection

Paul Green Papers

\section{PRINTED PRIMARY SOURCES}

Avery, Laurence G. ed. A Southern Life: Letters of Paul Green, 1916-1981. Chapel Hill: The University of North Carolina Press, 1994.

Brackenridge, H.H. ed. Narratives of a Late Expedition Against the Indians: With An Account of the Barbarous Execution of Colonel Crawford and the Wonderful Escape of Dr. Knight and John Slover from Captivity in 1782. Philadelphia: Francis Bailey, 1783.

Brainerd, Thomas. The Life of John Brainerd, the Brother of David Brainerd, and His Successor as Missionary to the Indians of New Jersey. Philadelphia: Presbyterian Publication Committee, 1865.

Butterfield, C.W. ed. Washington-Irvine Correspondence: The Official Letters Which Passed between Washington and Brig. General William Irvine and Others Concerning Military Affairs in the West from 1781-1783. Madison, WI: David Atwood, 1882.

De Schweinitz, Edmund. The History of the Church Known as the Unitas Fratrum, or the Unity of the Brethren, Founded by the Followers of John Hus, the Bohemian Reformers and Martyr, $2^{\text {nd }}$ Edition. Bethlehem, PA: The Moravian Publication Concern, 1901.

Doddridge, Joseph. Notes of the Settlement and Indian Wars of the Western Parts of Virginia and Pennsylvania from 1763 to 1783, inclusive, together a Review of the State of Society and Manners of the First Settlers of the Western Country. Pittsburgh: John S. Ritenour and William T. Lindsey, 1912. 
Dunn, Richard S. and Mary Maples Dunn, ed. The Papers of William Penn, Vol. 2. Philadelphia: University of Pennsylvania Press, 1982.

Franklin, Benjamin. The Autobiography of Benjamin Franklin. Boston: Houghton Mifflin \& Co., 1906.

Franklin, Benjamin. A Narrative of the Late Massacres, in Lancaster County, of a Number of Indians, Friends of this Province, By Persons Unknown, With Some Observations on the Same. Philadelphia: Franklin and Hall, 1764.

Franklin, Benjamin. The Papers of Benjamin Franklin, Volume 22. Edited by William B. Wilcox. New Haven: Yale University Press, 1982.

Gnadenhütten Monument Society. A True History of the Massacre of Ninety-Six Christian Indians, at Gnadenhütten, Ohio, March 8, 1782. New Philadelphia: Printed at the Ohio Democrat Office, 1870.

Gratz, B. and M. Merchants in Philadelphia. Jefferson City, MO: Hugh Stevens Printing Co., 1916.

Heckewelder, John. A Narrative of the Mission of the United Brethren Among the Delaware and Mohegan Indians, From Its Commencement, in the Year 1740, to the Close of the Year 1808. Philadelphia: McCarty \& Davis, 1820.

Heckewelder, John. "Names which the Lenni Lenape or Delaware Indians, who once inhabited this country, had given to Rivers, Streams, Places, \&c., with the now States of Pennsylvania, New Jersey, Maryland, and Virginia; and also Names of Chieftains and distinguished Men of that Nation; with the Significance of those Names, and Biographical Sketches of some of those Men." Edited by Peter S. Du Ponseau. Transactions of the American Philosophical Society 4 (1834): 351-96.

Heckewelder, John. History, Manners, and Customs of the Indian Nations who Once Inhabited Pennsylvania and the Neighboring States. Philadelphia: Publication Fund of the Historical Society of Pennsylvania, 1881.

Heckewelder, John. Thirty Thousand Miles with John Heckewelder. Edited by Paul A. W. Wallace. Pittsburgh: University of Pittsburgh Press, 1958.

Howe, Henry. Historical Collections of Ohio: An Encyclopedia of the State; History Both General and Local, Geography, Sketches of Eminent and Interesting Characters, etc. with Notes of a Tour Over It In 1886, Vol. 3. Columbus: Henry Howe \& Son, 1891.

Hulbert, Archer Butler and William Nathaniel Schwarze, ed. David Zeisberger's History of the Northern American Indians. Columbus: Press of F.J. Heer, 1910. 
Hunt, William Ellis. Historical Collections of Coshocton County, Ohio: A Complete Panorama of the County, From the Time of the Earliest Known Occupants of the Territory Until the Present Time. Cincinnati: Robert Clarke \& Co. Printers, 1876.

Jones, David. A Journal of Two Visits Made to Some Nations of Indians on the West Side of the River Ohio, In the Years 1772 and 1773. Burlington, N.J.: Isaac Collins, 1774.

Kellogg, Louise Phelps, ed. Frontier Advance on the Upper Ohio, 1778-1779, Draper Series Volume IV. Madison: The Society, 1916.

Kenny, James. The Journal of James Kenny, 1761-63. Edited by John W. Jordan. The Pennsylvania Magazine of History and Biography 37, no. 1 (1913): 1-47.

Killbuck, William Henry. "Letter to Governor Thomas McKean, January 8, 1805." The Pennsylvania Magazine of History and Biography 10, no. 1 (1886): 116-18.

Leeth, John. A Short Biography of John Leith, with a Brief Account of His Life Among the Indians. Cincinnati: Robert Clark \& Co., 1883.

Loskiel, George Henry. The History of the Moravian Mission Among the Indians in North America, From Its Commencement to the Present Time with a Preliminary Account of the Indian. Translated by Christian Ignatius La Trobe. London: Printed for the Brethren's Society for the Furtherance of the Gospel, 1794.

Lowrie, Walter ed. American State Papers: Documents, Legislative and Executive of the Congress of the United States in Relation to the Public Lands, from the First Session of the First Congress to the First Session of the Twenty-Third Congress: March 4, 1789 to June 15, 1834.

Duff Green: Washington, 1834.

McCullough, John. "A Narrative of the Captivity of John McCullough." In A Selection of Some of the Most Interesting Narratives of Outrages, Committed by the Indians, In their Wars with the White People. Edited by Archibald Loudon, 272-76. Carlisle, PA: Press of A. Loudon, 1808.

Minutes of the Provincial Council of Pennsylvania, From the Organization to the Termination of the Proprietary Government, Volume 6. Harrisburg: Theo. Fenn \& Co., 1851.

Minutes of the Provincial Council of Pennsylvania: From the Organization to Termination of the Proprietary Government, Volume 7. Harrisburg: Theo Fenn \& Co., 1851.

Navarre, Robert. Journal of Pontiac's Conspiracy. Translated by R. Clyde Ford. Detroit: Clarence Monroe Burton, 1910.

Pennsylvania Archives: Selected and Arranged from Original Documents, Volume 9. Edited by Samuel Hazard. Philadelphia: Joseph Severns \& Co., 1854. 
Pond, Enoch. Memoir of Count Zinzendorf: Comprising a Succinct History of the Church of the United Brethren from Its Renewal at Herrnhut to the Death of Its Illustrious Patron. Boston: Massachusetts Sabbath School Society, 1839.

Quaife, Milo Milton ed. The Siege of Detroit in 1763: The Journal of Pontiac's Conspiracy and John Rutherfurd's Narrative of a Captivity. Chicago: R.R. Donnelley \& Sons Company, 1958.

Reichel, William C. ed. Memorials of the Moravian Church, Volume 1. Philadelphia: J.B. Lippincott \& Co., 1870.

Rimius, Henry. A Candid Narrative of the Rise and Progress of the Herrnhutters, Commonly Call'd Moravians or Unitas Fratrum, with a Short Account of their Doctrines Drawn from Their Own Writings. London: A. Linde, 1753.

Schoepf, Johann David. Travels in the Confederation, 1783-1784, Volume 1. Edited and Translated by Alfred J. Morrison. William J. Campbell: Philadelphia, 1911.

Smith, William. A Brief State of the Province of Pennsylvania, Second Edition. London: R. Griffiths, 1755.

Spangenberg, August Gottlieb. The Life of Nicholas Lewis Count Zinzendorf, Bishop and Ordinary of the Church of the United (or Moravian) Brethren. Translated by Samuel Jackson. London: Samuel Holdsworth, 1838.

Stocker, Harry E. Moravian Customs and Other Matters of Interest. Bethlehem, PA: Times Publishing Co., 1918.

Tennent, Gilbert. Some Account of the Principles of the Moravians: Chiefly Collected from Several Conversations with Count Zinzendorf; and from some sermons. London: Printed for S. Mason, 1743.

Thwaites, Reuben Gold and Louise Phelps Kellogg, ed. Frontier Defense of the Upper Ohio, 1777-1778, Draper Series Volume III. Madison: Wisconsin Historical Society, 1912.

Vaughan, Alden T. ed. Early American Indian Documents: Treaties and Laws, 1607-1789, Vol. 2. Frederick, MD.: University Publications of America, 1984.

Whitefield, George. An Expostulatory Letter Addressed to Nicholas Lewis, Count Zinzendorf, and Lord Advocate of the Unitas Fratrum, $2^{\text {nd }}$ Edition. London: Printed for G. Keith, 1753.

. The Works of the Reverend George Whitefield, M.A. Late of Pembroke-College, Oxford, and Chaplain to the Rt. Hon. the Countess of Huntingdon. London: Printed for Edward and Charles Dilly, 1771. 
Zeisberger, David. The Moravian Mission Diaries of David Zeisberger, 1772-1781. Edited by Herman Wellenreuther and Carola Wessel. Translated by Julie Tomberlin Weber. University Park: The Pennsylvania State University Press, 2005.

. Diary of David Zeisberger, A Moravian Missionary Among the Indians of Ohio:

1781-1798, Volume 1. Edited and Translated by Eugene Bliss. Cincinnati: Robert Clarke \& Co., 1885.

. David Zeisberger's History of the Northern American Indians. Edited by Archer

Butler Hubert and William Nathaniel Schwarze. Columbus: Press of F.J. Heer, 1910.

Zinzendorf, Count N.L. Twenty-One Discourses or Dissertations Upon the AugsburgConfession, Deliver'd by the Ordinary of the Brethren's Churches Before the Seminary.

Translated by by F. Okeley. London: W. Bowyer, 1753.

\section{NEWSPAPERS}

The Pennsylvania Gazette

\section{BOOKS}

Atwood, Craig D. Community of the Cross: Moravian Piety in Colonial Bethlehem. University Park: The Pennsylvania State University Press, 2004.

. The Theology of the Czech Brethren from Hus to Comenius. University Park: The Pennsylvania State University Press, 2009.

Axtell, James. The European and the Indian: Essays in the Ethnohistory of Colonial North America. New York: Oxford University Press, 1981.

. Natives and Newcomers: The Cultural Origins of North America. University Park:

The Pennsylvania State University Press, 2001.

Bell, Whitfield J. Patriot Improvers: Biographical Sketches of Members of the American

Philosophical Society, Volume II. Philadelphia: American Philosophical Society, 1999.

Boyd, Julian P. ed. Indian Treaties Printed by Benjamin Franklin, 1736-1762. Philadelphia: Historical Society of Pennsylvania, 1938.

Buijtenen, Mari Van, Cornelius Dekker, and Huib Leeuwenberg, ed., Unitas Fratrum. Utrecht: Rijksarchief, 1975.

Calloway, Colin. The Scratch of a Pen: 1763 and the Transformation of North America. New York: Oxford University Press, 2006.

Camenzind, Krista. "Violence, Race and the Paxton Boys." In Friends and Enemies in Penn's Woods: Indians, Colonists, and the Racial Construction of Pennsylvania, edited by William A. 
Pencak and Daniel Richter, 201-220. University Park: The Pennsylvania State University Press, 2004.

Cornell, Saul. The Other Founders: Anti-Federalism and the Dissenting Tradition in America, 1788-1828. Chapel Hill: The University of North Carolina Press, 1999.

Cronan, William. Changes in the Land: Indians, Colonists, and the Ecology of New England. New York: Hill and Wang, 1983.

De Schweinitz, Edmund. The Life and Times of David Zeisberger: The Western Pioneer and Apostle of the Indians. Philadelphia: J.B. Lippincott \& Co., 1871.

Dixon, David. Never Come to Peace Again: Pontiac's Uprising and the Fate of the British Empire in North America. Norman: University of Oklahoma Press, 2005.

Dowd, Gregory Evans. A Spirited Resistance: The North American Indian Struggle for Unity, 1745-1815. Baltimore: The Johns Hopkins University Press, 1992.

. War Under Heaven: Pontiac, The Indian Nations, and The British Empire.

Baltimore: The Johns Hopkins University Press, 1992.

Downes, Randolph C. Council Fires on the Upper Ohio: A Narrative of Indian Affairs in the Upper Ohio Valley Until 1795. Pittsburgh: University of Pittsburgh Press, 1940.

DuVal, Kathleen . The Native Ground: Indians and Colonists in the Heart of the Continent. Philadelphia: University of Pennsylvania Press, 2006.

Egle, William Henry ed., Notes and Queries Historical and Genealogical Chiefly Relating to Interior Pennsylvania, Volume 3. Harrisburg: Harrisburg Publishing Company, 1896.

Engel, Katherine Carté. Religion and Profit: Moravians in Early America. Philadelphia: University of Pennsylvania Press, 2011.

Faull, Katherine, ed. Masculinity, Senses, Spirit. Bucknell, PA: Bucknell University Press, 2011.

Fenn, Elizabeth. Pox Americana: The Great Smallpox Epidemic of 1775-82. New York: Hill and Wang, 2001.

Fisher, Linford. The Indian Great Awakening: Religion and the Shaping of Native Cultures in Early America. New York: Oxford University Press, 2012.

Fogleman, Aaron. Jesus is Female: Moravians and the Challenge of Radical Religion in Early America. Philadelphia: University of Pennsylvania Press, 2007.

Fur, Gunlog Maria. A Nation of Women: Gender and Colonial Encounters Among the Delaware Indians. Philadelphia: University of Pennsylvania Press, 2009. 
Gillespie, Michele and Robert Beachy, ed., Pious Pursuits: German Moravians in the Atlantic World. New York: Berghahn Books, 2007.

Goodman, Alfred. T. "First White Child in Ohio." In Western Reserve and Northern Ohio Historical Society, no 4. Cleveland: Western Reserve Historical Society, 1871.

Griffin, Patrick. American Leviathan: Empire, Nation, and Revolutionary Frontier. New York: Hill and Wang, 2007.

Hall, David D. Worlds of Wonder, Days of Judgment: Popular Religious Belief in Early New England. New York: Alfred A. Knopf, 1989.

Hamilton, Kenneth. John Ettwein and the Moravian Church During the Revolutionary Period Bethlehem, PA: Times Publishing, 1940.

Irwin, Lee. Coming Down From Above: Prophecy, Resistance, and Renewal in Native American Religions. Norman: University of Oklahoma Press, 2008.

Jordon, Francis. The Life of William Henry, of Lancaster, Pennsylvania, 1729-1786, Patriot, Military Officer, Inventor of the Steamboat. Lancaster, PA: New Era Printing Company, 1910.

Kann, Mark E. A Republic of Men: The American Founders, Gendered Language, and Patriarchal Politics. New York: New York University Press, 1998.

Kidd, Thomas. The Great Awakening: Roots of Evangelical Christianity in Colonial America. New Haven: Yale University Press, 2007.

Lambert, Frank. Inventing the 'Great Awakening'. Princeton: Princeton University Press, 2001.

LeMaster, Michelle. Brothers Born of One Mother: British-Native American Relations in the Colonial Southeast. Charlottesville: University of Virginia Press, 2012.

Levering, Joseph Mortimer. A History of Bethlehem, Pennsylvania: 1741-1892. Bethlehem, PA: Times Publishing Company, 1903.

Lindman, Janet Moore. "Play the Man...for Your Bleeding Country": Military Chaplains as Gender Brokers During the American Revolutionary War.” In New Men: Manliness in Early America, edited by Thomas A. Foster, 236-55. New York: New York University Press, 2011.

Little, Ann M. Abraham in Arms: War and Gender in Colonial New England. Philadelphia: University of Pennsylvania Press, 2007.

Martin, Calvin. Keepers of the Game: Indian Animal Relationships and the Fur Trade. Berkeley: University of California Press, 1978. 
MacMaster, Richard K., Samuel L. Horst, and Robert F. Ulle. Conscience in Crisis: Mennonites and Other Peace Churches in America, 1739-1789. Scottsdale, PA: Herald Press, 1979.

McConnell, Michael. A Country Between: the Upper Ohio Valley and Its Peoples, 1724-1774. Lincoln: University of Nebraska Press, 1992.

Merrell, James. Into the American Woods: Negotiators on the Pennsylvania Frontier. New York: W.W. Norton \& Company, 1999.

Merritt, Jane. At the Crossroads: Indians and Empires on a Mid-Atlantic Frontier, 1700-1763. Chapel Hill: University of North Carolina Press, 2003.

Nelson, Vernon. “The Moravian Church in America." In Unitas Fratrum, edited by Mari Van Buijtenen, Cornelius Dekker, Huib Leeuwenberg, 145-9, Utrecht: Rijksarchief, 1975.

The Ohio Guide, Writers' Program of the Works Projects Administration in the State of Ohio. New York: Oxford University Press, 1940.

Olmstead, Earl P. David Zeisberger: A Life Among the Indians. Kent, OH: Kent State University Press, 1997.

Peucker, Paul. A Time of Sifting: Mystical Marriage and the Crisis of Moravian Piety in the Eighteenth-Century. University Park: Penn State University Press, 2015.

. "Wives of the Lamb: Moravian Brothers and Gender around 1750." In Masculinity, Senses, Spirit, edited by Katherine Faull, 39-54. Bucknell: Bucknell University Press, 2011.

Preston, David L. "Squatters, Indians, Proprietary Government, and Land in the Susquehanna Valley." In Friends and Enemies in Penn's Woods: Indians, Colonists, and the Racial Construction of Pennsylvania, edited by William A. Pencek and Daniel Richter, 180-200. University Park: The Pennsylvania State University Press, 2004.

Richter, Daniel K. and James H. Merrell. Beyond the Covenant Chain: The Iroquois and Their Neighbors in Indian North America, 1600-1800. University Park: The Pennsylvania State University Press, 1987.

Ritter, Abraham. The History of the Moravian Church in Philadelphia from its Founding in 1742 until the Present Time. Philadelphia: Hays \& Zell, 1857.

Romero, R. Todd. Making War and Minting Christians: Masculinity, Religion, and Colonialism in Early New England. Amherst: University of Massachusetts Press, 2011.

Rupp, Daniel I. History of Lancaster County: To Which is Prefixed a Brief Sketch of the Early History of Pennsylvania. Lancaster PA: Published by Gilbert Hills, 1844. 
Schaaf, Gregory. Wampum Belts and Peace Trees: George Morgan, Native Americans, and Revolutionary Diplomacy. Golden, CO: Fulcrum Publishing, 1990.

Schutt, Amy. Peoples of the River Valleys: The Odyssey of the Delaware Indians. Philadelphia: University of Pennsylvania Press, 2007.

Schutt, Amy. "Female Relationships and Intercultural Bonds in Moravian Indian Missions." In Friends and Enemies in Penn's Woods: Indians, Colonists, and the Racial Construction of Pennsylvania, edited by William A. Pencak and Daniel Richter, 87-103. University Park: The Pennsylvania State University Press, 2004.

Shaffer, Marguerite S. See America First: Tourism and National Identity, 1880-1940. Washington: Smithsonian Institution Press, 2001.

Shoemaker, Nancy. A Strange Likeness: Becoming Red and White in Eighteenth-Century North America. New York: Oxford University Press, 2004.

Silver, Peter. Our Savage Neighbors: How Indian War Transformed Early America. New York: W.W. Norton and Company, 2008.

Smaby, Beverley. The Transformation of Moravian Bethlehem: From Communal Mission to Family Economy. Philadelphia: University of Pennsylvania Press, 1988.

Wallace, Anthony F.C. The Death and Rebirth of the Seneca. New York: Alfred A. Knopf, 1969. Press, 1949. . King of the Delawares: Teedyuscung. Philadelphia: University of Pennsylvania

Wallace, Paul A. W. Conrad Weiser, 1696-1760, Friend of Colonist and Mohawk. Philadelphia: University of Pennsylvania, 1945.

Wheeler, Rachel. To Live Upon Hope: Mohicans and Missionaries in the Eighteenth-Century Northeast. Ithaca: Cornell University Press, 2008.

White, Richard. The Middle Ground: Indians, Empires, and Republics in the Great Lakes Region, 1650-1815. New York: Cambridge University Press, 1991.

\section{JOURNAL ARTICLES}

Barr, Daniel. "A Road for Warriors: The Western Delaware And The Seven Years' War," Pennsylvania History: A Journal of Mid-Atlantic Studies 73, no. 1 (Winter 2006): 1-36.

Burkholder, Jared S. "Neither 'Kriegerisch nor Quakerisch: Moravians and the Question of Violence in Eighteenth-Century Pennsylvania.” Journal of Moravian History 12 (2012): 143-69.

Butler, Jon. "Enthusiasm Described and Decried: The Great Awakening as Interpretive Fiction." Journal of American History 69, no. 2 (September 1982): 305-25. 
Calloway, Colin. "We Have Always been the Frontier: the American Revolution in Shawnee Country." American Indian Quarterly 16, no. 1 (Winter 1992): 39-52.

Faull, Katherine. "Masculinity in the Eighteenth-Century Moravian Mission Field: Contact and Negotiation.” Journal of Moravian History 13, no. 1 (2013): 27-53.

Fogleman, Aaron. "Jesus is Female: the Moravian Challenge in the German Communities of British North America." The William and Mary Quarterly 60 (April 2003): 295-332.

Gollin, Lillian. "Family Surrogates in Colonial America: The Moravian Experiment." Journal of Marriage and Family 31 (November 1969): 650-8.

Gordon, Scott Paul. "Entangled by the World: William Henry of Lancaster and "Mixed" Living in Moravian Towns and Country Congregations." Journal of Moravian History 8 (2010): 7-52.

. "Patriots and Neighbors: Pennsylvania Moravians in the American Revolution." Journal of Moravian History 12, no. 2 (2012): 111-42.

."The Paxton Boys and the Moravians: Terror and Faith in the Pennsylvania Backcountry." Journal of Moravian History 14, no. 2 (2014): 199-52.

. "The Killbuck-Henry Legend Revisited, Part 1." The Jacobsburg Record 37, no. 1 (February 2010): 1-7.

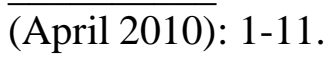

. "The Killbuck-Henry Legend Revisited, Part 2." The Jacobsburg Record 37, no. 3

. "The Henrys and the West: Moses Henry, Gunsmith and Indian Agent." The

Jacobsburg Record 35, no. 1 (March 2008): 6-10.

Harper, Rob. "Looking the Other Way: The Gnadenhütten Massacre and the Contextual Interpretation of Violence." The William and Mary Quarterly 64, no. 3 (July 2007): 621-44.

Ingram, Daniel. “Anxious Hospitality: Indian 'Loitering' at Fort Allen, 1756-1761.” The Pennsylvania Magazine of History and Biography 133, no. 3 (July 2009): 221-53.

Jordan, John. "James Burnside of Northampton County, Pennsylvania." The Pennsylvania Magazine of History and Biography 21, no. 1 (1897): 177-18.

3 (1909): 340-6.

."William Parsons.” The Pennsylvania Magazine of History and Biography 33, no.

Merritt, Jane T. "Cultural Encounters Along a Gender Frontier: Mahican, Delaware, and German Women in Eighteenth-Century Pennsylvania." Pennsylvania History: A Journal of Mid-Atlantic Studies 67, no. 4 (Autumn 2000): 503-32. 
. "Dreaming in the Savior's Blood: Moravians and the Indian Great Awakening in Pennsylvania." The William and Mary Quarterly 54, no. 4 (October 1997): 723-46.

Peucker, Paul. "Inspired by Flames of Love": Homosexuality, Mysticism, and Moravian Brothers around 1750." Journal of the History of Sexuality 15, no.1 (January 2006): 30-64.

Schutt, Amy. "'What Will Become of Our Young People?': Goals for Indian Children in Moravian Missions.” History of Education Quarterly 38, no. 3 (Autumn 1998): 268-86.

Smaby, Beverly. "Female Piety Among Eighteenth Century Moravians." Pennsylvania History 64 (Summer 1997): 151-67.

Shoemaker, Nancy. "How Indians Got to be Red." The American Historical Review 102 (1997): 625-44.

Wellenreuther, Hermann. "White Eyes and the Delaware's Vision of an Indian State."

Pennsylvania History: A Journal of Mid-Atlantic Studies 68, no. 2 (Spring 2001): 139-61.

“What's Going On.” History News 26 no. 10 (October 1971): 230-2.

Zorb, Elizabeth. "Reflections on Moravian Pietism." Pennsylvania History: A Journal of MidAtlantic Studies 25, no. 2 (April 1958): 115-21.

\section{DISSERTATIONS}

Camenzind, Krista. "From the Holy Experiment to the Paxton Boys: Violence, Manhood and Race in Pennsylvania During the Seven Years' War." Ph.D. diss., University of California, San Diego, 2002.

Grimes, Richard. "The Emergence and Decline of the Delaware Indian Nation in Western Pennsylvania and the Ohio Country, 1730-1795.” Ph.D. Diss, West Virginia University, 2005.

Schutt, Amy. "Forging Identities: Native Americans and Moravian Missionaries in Pennsylvania and Ohio, 1765-1782." Ph.D. diss., Indiana University, 1995.

MISCELLANEOUS PUBLICATIONS (Websites, Digital Archive Collections) American Philosophical Society, Treasures of the APS Digital History Project (https://www.amphilsoc.org/exhibits/treasures/index.htm)

Bethlehem Digital History Project (http://bdhp.moravian.edu/home/home.html)

Davis, Cindy. "Event Marks Massacre of Moravian Delaware Indians in Gnadenhütten," Columbus Monthly, March 12, 2017, http://www.columbusmonthly.com/news/20170312/eventmarks-massacre-of-moravian-delaware-indians-in-gnaden

Eelünaapéewilahkéewiit Delaware Nation, http://delawarenation.on.ca 
Founders Online, National Archives, https://founders.archives.gov/about.

Gallagher, Robert L. "Zinzendorf and the Early Moravian Mission Movement.” Paper presentation, Wheaton College, September 21, 2005, https://www.scribd.com/document/212680155/Zinzendorf-and-the-Early-Moravian-MissionMovement

"Gnadenhütten.” The Ohio History Connection Historic Marker Database, Remarkable Ohio, http://www.remarkableohio.org/index.php?/category/1428

Our Documents Initiative, https://www.ourdocuments.gov/index.php?flash=false\&.

Parkhill, S.M. “Crown Inn Housed Bethlehem's Early Visitors,” The Morning Call, June 16, 1998 http://articles.mcall.com/1998-06-16/news/3194833_1_sun-inn-moravians-farms.

"Schoenbrunn Village," Ohio History Connection, https://www.ohiohistory.org/visit/museumand-site-locator/schoenbrunn-village.

University of Pittsburgh Special Collections, Darlington Digital Collection

(http://digital.library.pitt.edu/d/darlington/). 